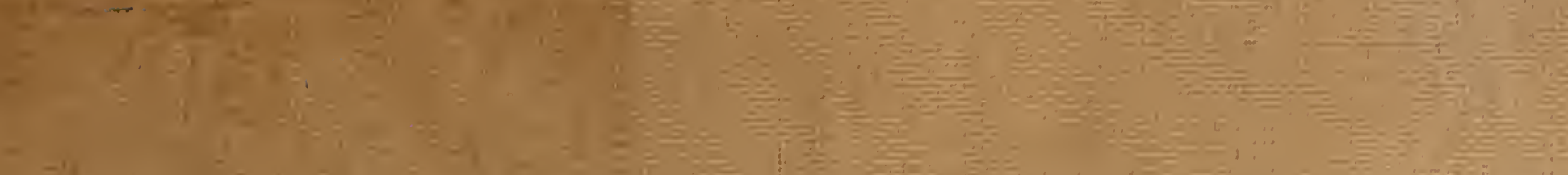

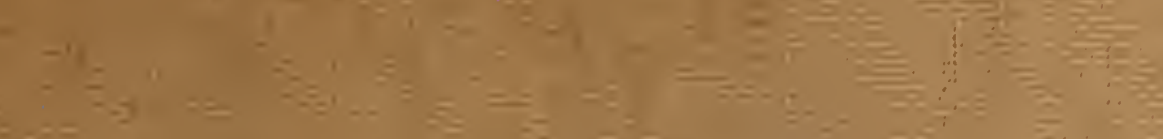$$
\text { 1 }
$$$$
\text { Ans }
$$

$=$

$$
\text { If } 20
$$

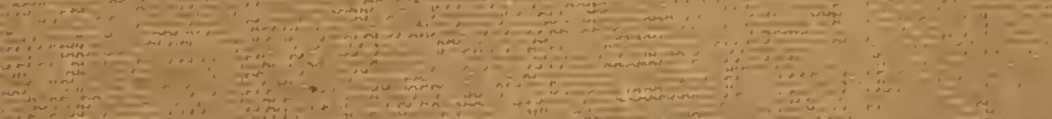

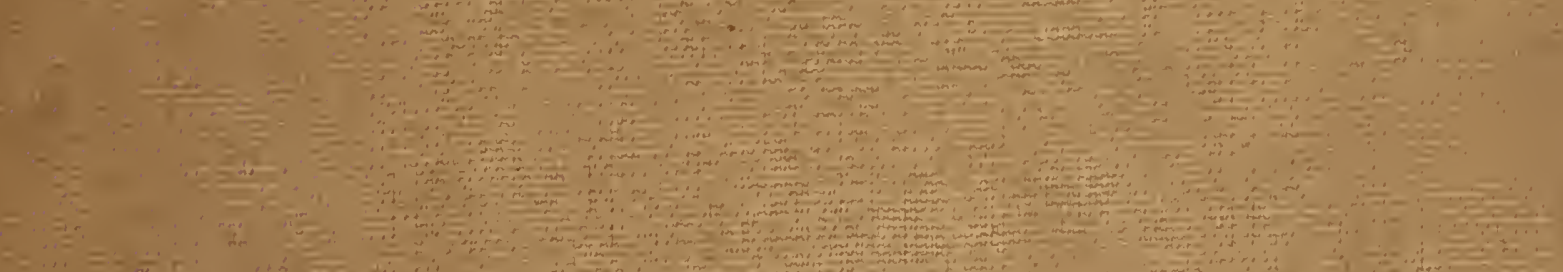
2,0

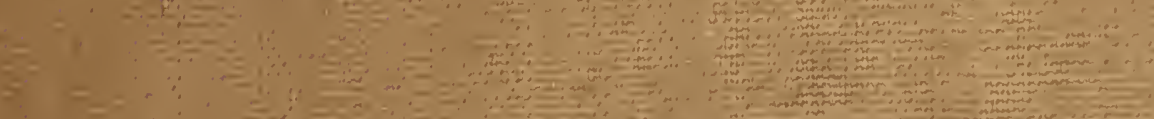

and

and

40 and

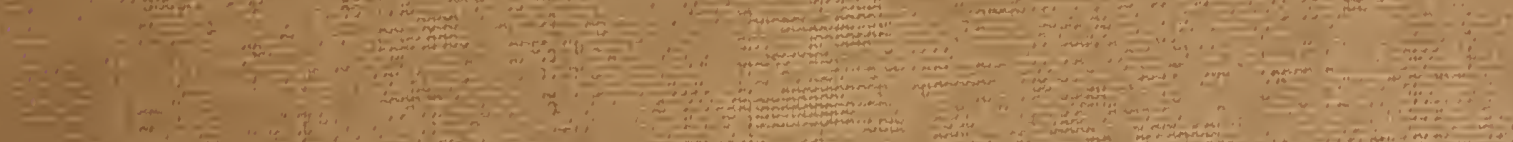

(1)

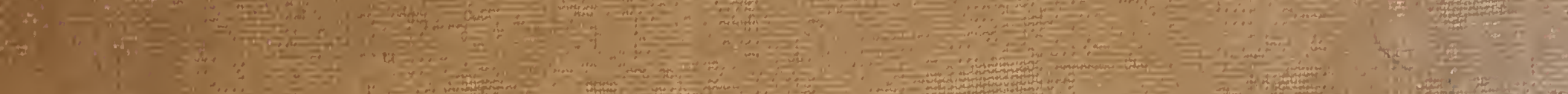



WILSON COPEPOD LIBRAPY

Smithsonian Instilution

Invertebrate Zoology

(Crustacea) 

WILSON COPEPOD LIBRARY.

Smithsonian Institution

Invertebrate Zoo!ogy

(Crustacea) 


\section{R E P O R T}

ON THE
WILSON COPEPOD LIBRARY

Smithsonian Institution

Invertebrate Zoology

(Crustacea)

\section{SCIENTIFIC RESULTS}

OF THE

\section{VOYAGE OF H.M.S. CHALLENGER}

D) URING THE YEARS I $873-76$

UNDER THE COMMAND OF

Captain GEORGE S. NARES, R.N., F.R.S.

AND

CAPTAIN FRANK TOURLE THOMSON, R.N.

PREPARED UNDER THE SUPERINTENDENCE OF

THE LATE

Sir C. WYVILLE THOMSON, Knt., F.R.S., \&c. REGIUS PROFESSOR OF NATURAL HISTORY IN THE UNIVERSITY OF EDINBURGH DIRECTOR OF THE CIVILIAN SCIENTIFIC STAFF ON BOARD

AND NOW OF

J O H N M R R A , F.R.S.E. ONE OF THE NATURALISTS OF THE EXPEDITION

ZOOLOGY-VOL. VIII. PART XXIII.-REPORT ON THE COPEPODA

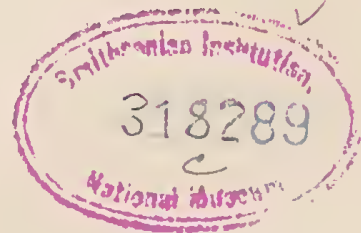

10ublisbed by Order of ber Atajestu’s Ganernment

nition

PRINTED FOR HER MAJESTY'S STATIONERY OFFICE

AND SOLD BX

LONDON :-LONGMANS \& CO.; JOHN MURRAY; MACMILLAN \& CO.; SIMPKIN, MARSHALL \& CO.

TRÜBNER \& CO.; E. STANFORD; J. D. POTTER; AND KEGAN PAUL, TRENCH, \& CO.

EDINBURGH :-ADAM \& CHARLES BLACK AND DOUGLAS \& FOULIS.

DUBLIN :-A. THOM \& CO. AND HODGES, FIGGIS, \& CO.

1883

Price Truenty-four Shillings. 



\section{EDITORIAL NOTE.}

This Report on the Coperoda, by Dr. George Stewarlson Brady, F.R.S., forms Part XXIII. of the Zoological Series of Reports on the Scientific Results of the Expedition. The Manuscript was received on the 1st August 1883.

It will be remembered that the Report on the Ostracoda collected during the Expedition, by Dr. Brady, was published in 1880, and forms Part III. of the Zoological Series of Reports.

JoHN Murray.

Challenger Office, 32 Queen Street,

Edinburgh, 28th December 1883. 


\section{ERRATUM.}

Page 111, line 22, delete (Fig. 1, a). 


\section{VOYAGE OF H.M.S. CHALLENGER.}

\section{Z O O L O GY.}

\section{REPORT on the COPEPODA collected by H.M.S. Challenger during the years 1873-76. By George Stewardson Brady, M.D., F.R.S., F.L.S.}

THE Copepoda noticed in this Report were taken almost entirely from surface-net gatherings made during the cruise; some few collections were made in the tow-net, at various depths below the surface, and a still smaller number by the "tow-net at trawl"; and lastly, a few specimens were found entangled on the swabs of the dredge. But where nothing of this kind is specified, it may be taken for granted that the captures were made at the surface. The material so obtained was mostly preserved in rectified spirit, a method which hardens the animals, rendering them opaque, destroying, usually, every trace of the natural colour, and obscuring almost entirely the internal anatomy. ${ }^{1}$ In addition to these spirit-specimens, there was a comparatively small series mounted for the microscope in Canada balsam or glycerine, and from some of these details of structure were got which were unattainable in other cases.

The entire series of tow-net gatherings brought home from the different areas worked over by the Challenger was carefully examined. A list of the most important of these, with the names of the Copepoda found in each, is given hereafter (p. 7 et seq.). In many cases no Copepoda at all were found. ${ }^{2}$ This, however, cannot be considered a point of any importance, for there can be no manner of doubt that the sea, from the equator to the

1 A really good preservative solution-one not only protecting from mould and decay, but also preserving the natural transparency and colours of the tissues, while giving them a serviceable firmness-is yet to be discovered. Alcohol, in other respects perfect, has the great disadvantage of destroying both colour and transparency, and glycerine, though almost free from these defects, is a most unpleasant medium, on account of its density and stickiness. On the whole, a saturated solution of boracic acid in glycerine, diluted with three or four parts of water, has given in my hands the best results; but my preparations so made have not yet had sufficient time for fair trial.

2 This statement refers to the preserved specimens sent to Dr. Brady. As a matter of fact, Copepoda were rarely, if ever, absent from the tow-net gatherings when examined on board ship.-J. M.

(ZOOL. CHALL. EXP.-PART XXII.-1883.) 
poles, supports everywhere a profusion of Entomostracan life, chiefly of the order Copepoda. But the appearance of these minute creatures at the surface depends upon conditions, the nature of which we scarcely at all understand. Night, on the whole, seems to be more favourable than daytime $;^{1}$ but even during the day they sometimes appear in numbers so vast as to colour the sea in wide bands for distances of many miles. This appearance has been noticed, perhaps, most frequently in the tropics; but even in the Arctic seas some species, especially Calanus (Cetochilus) finmarchicus, are at times so abundant as to constitute, it is said, a most important item in the food of the whale. So far, indeed, as number and size of individuals are concerned, it would appear that the cold water of the Arctic and Antaretic seas are even more favourable to the growth of Copepoda than the warmer areas of the tropics. In the cold polar seas Calanus finmarchicus, and perhaps other nearly allied forms, are the most characteristic members of the surface-fauna; while, if we may judge by the results of the Challenger Expedition, the warm equatorial and sub-tropical areas present a much greater variety of Copepoda, but no one species in very preponderating abundance. If we might venture to assign to the tropical and warmer temperate seas, one or more species holding the same position there as Calanus finmarchicus in the cold zones, we should name Undina darvinii and Euchota prestandrece; but there are several other species which would follow close upon the heels of these two.

As in the case of many other purely pelagic or aquatic animals, the range of distribution of many of the marine Copepoda is extremely wide ${ }^{2}$ : to find a free-swimming species ranging over a very small district is a rare exception, and the probability is that where this appears to be the case, further research will usually reveal its presence throughout a larger area.

The seven geographical areas adopted in the Table of Distribution are identical with those used in the Report on the Ostracoda. ${ }^{3}$ Of the ninety free-swimming species

1 Take, for example, the lists of two surface-net gatherings from Port Jackson (pp. 10,11), one taken by day, containing ten species, the other by night, fifteen species. This, by itself, is not of much account, but my friend Mr. David Robertson and myself have found, in a pretty large experience of surface-net work in the British Seas, that several kinds of Entomostraca-Ostracoda as well as Copepoda--are got commonly at night, but rarely, if at all, during the day.

2 An interesting example of the very wide distribution of pelagic, as opposed to terrestrial or abyssal animals, was noticed in the report on the Ostracoda-the only species found in all the seven areas being two natatory animalsHalocypris atlantica and Halocypris brevirostris.

3 The Stations are divided amongst the seven areas as follows :-

1. North Atlantic Ocean (Stations 1 to 110 and 348 to 354 ).

2. South Atlantic Ocean (Stations 111 to 142 and 313 to 347 ).

3. South Indian Ocean or Southern Ocean, extending to the Antarctic Circle (Stations 143 to 160).

4. Australasia, including the Coasts of Australia, New Zealand, and the Eastern Archipelago south of the equator (Stations 161 to 196 and 217 to 220 ).

5. South Pacific Ocean (Stations 271 to 312 ).

6. North Pacific Ocean (Stations 238 to 270).

7. Eastern Asia, including China, Japan, and the Eastern Archipelago north of the equator (Stations 197 to 216 and 221 to 237 ). 
here tabulated, only one (Euchcota prestandrece) was found in all the seven districts, but no fewer than nine species occurred in all but one of the areas; these being Calanus propinquus, Eucalanus attenuatus, Scolecithrix dance, Pleuromma abdominale, Undina darwinii, Centropages violaceus, Candace truncata, Corycaus varius, and Oncaea obtusa. Undina darwinii, Scolecithrix dana, Centropages violaceus, Corycaus varius, and Oncaec obtusa were not found in the Southern Indian Ocean; but this area was not investigated north of latitude $43^{\circ} \mathrm{S}$, and it is more than likely that the tropical zone of that ocean would have produced these species abundantly. Pleuromma abdominale was wanting, in the gatherings from Eastern Asia, and Candace truncata from the South Pacific. All nine species usually occur in considerable abundance, excepting, perhaps, Centropages violaceus, which is certainly much scarcer than the rest. The area producing the smallest number of species (fifteen), is the South Indian Ocean, doubtless for the reason already stated; from the North Pacific the number is not much greater, twenty-two. Leaving out of consideration the fish-parasites, the largest numbers of species were obtained from the North Atlantic, South Atlantic, Eastern Asiatic, and Australasian seas, the numbers from each of these areas being forty-eight, forty-eight, forty-five, and forty-two respectively. The only undoubted deep-sea species is Pontostratiotes abyssicola, the single specimen of which-dredged in a depth of 2200 fathoms-was picked from the dried mud, having unfortunately lost much character in the drying process. Some others were got in deep hauls of the tow-net, but these were usually either well-known species, or so much battered as to make recognition impossible, and it is very likely that most of them were captured during the passage of the net towards the surface. Calanus princeps may, however, be noted as an exception to this statement, the two or three specimens from which our knowledge of the species is derived, having come up with deep bauls of the dredge, and most probably from the very depths of the sea. Possibly we might also include amongst abyssal species Hemicalanus aculeatus, Phyllopus bidentatus, and one or two Euchcetoe (see lists, pp. 19 and 22), but it is not by any means certain that these specimens came from the bottom.

The fish-parasites are remarkably few, considering the attention which was paid to ichthyology, and the considerable number of fishes captured during the expedition. All the species that have come under my observation are noted in these pages. 
Geographical Distribution of the Copepoda collected during the Cruise of H.M.S. Challenger.

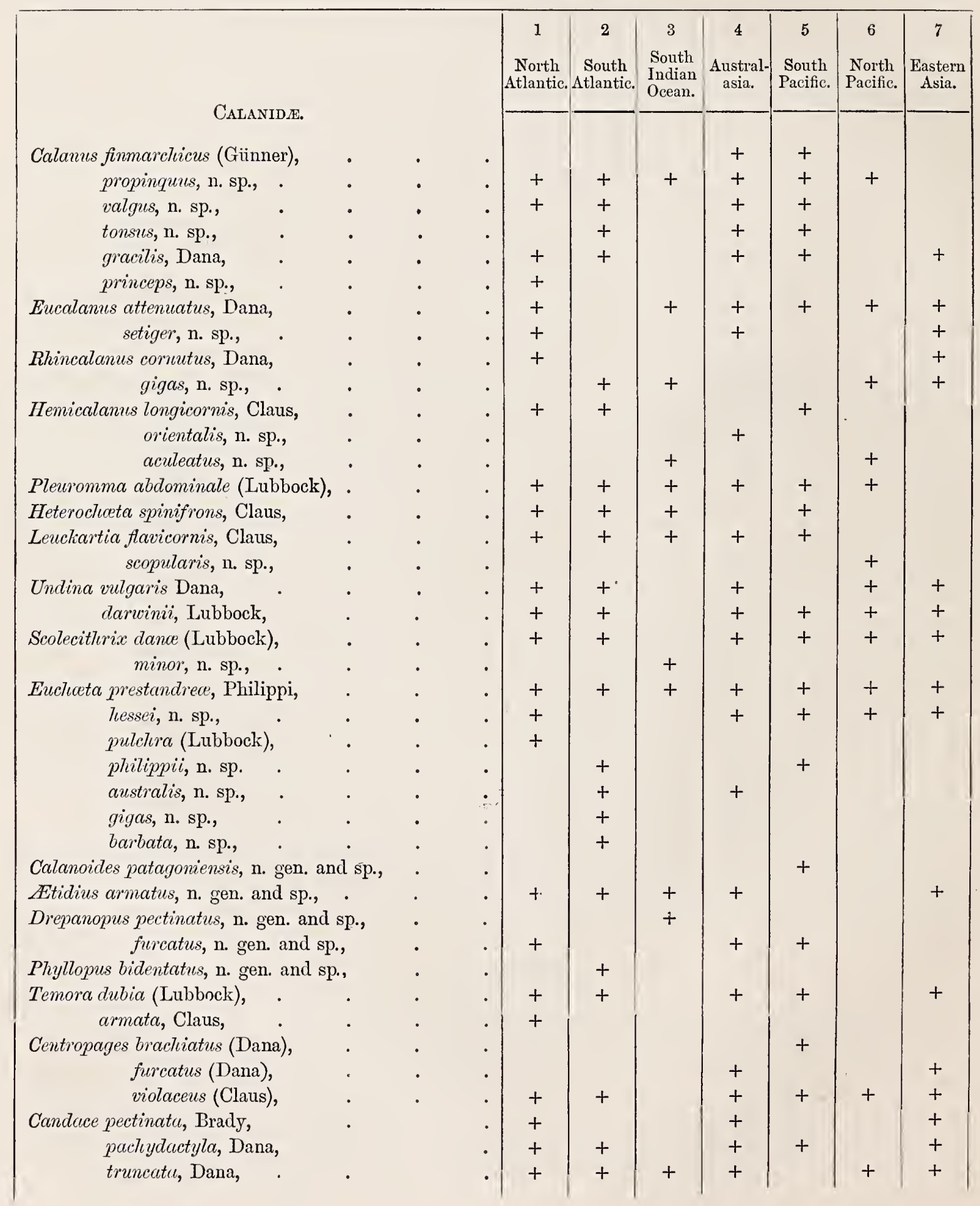




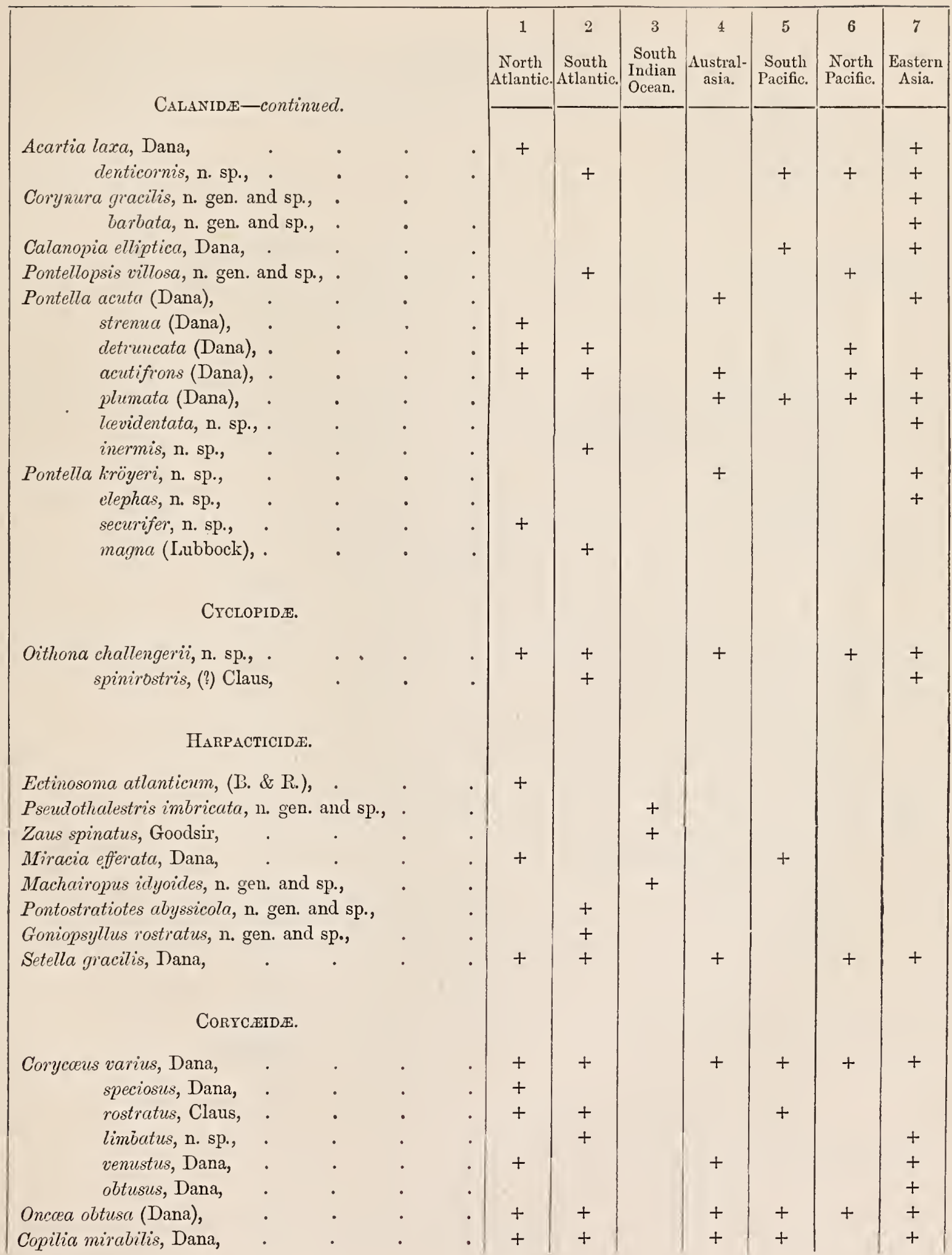




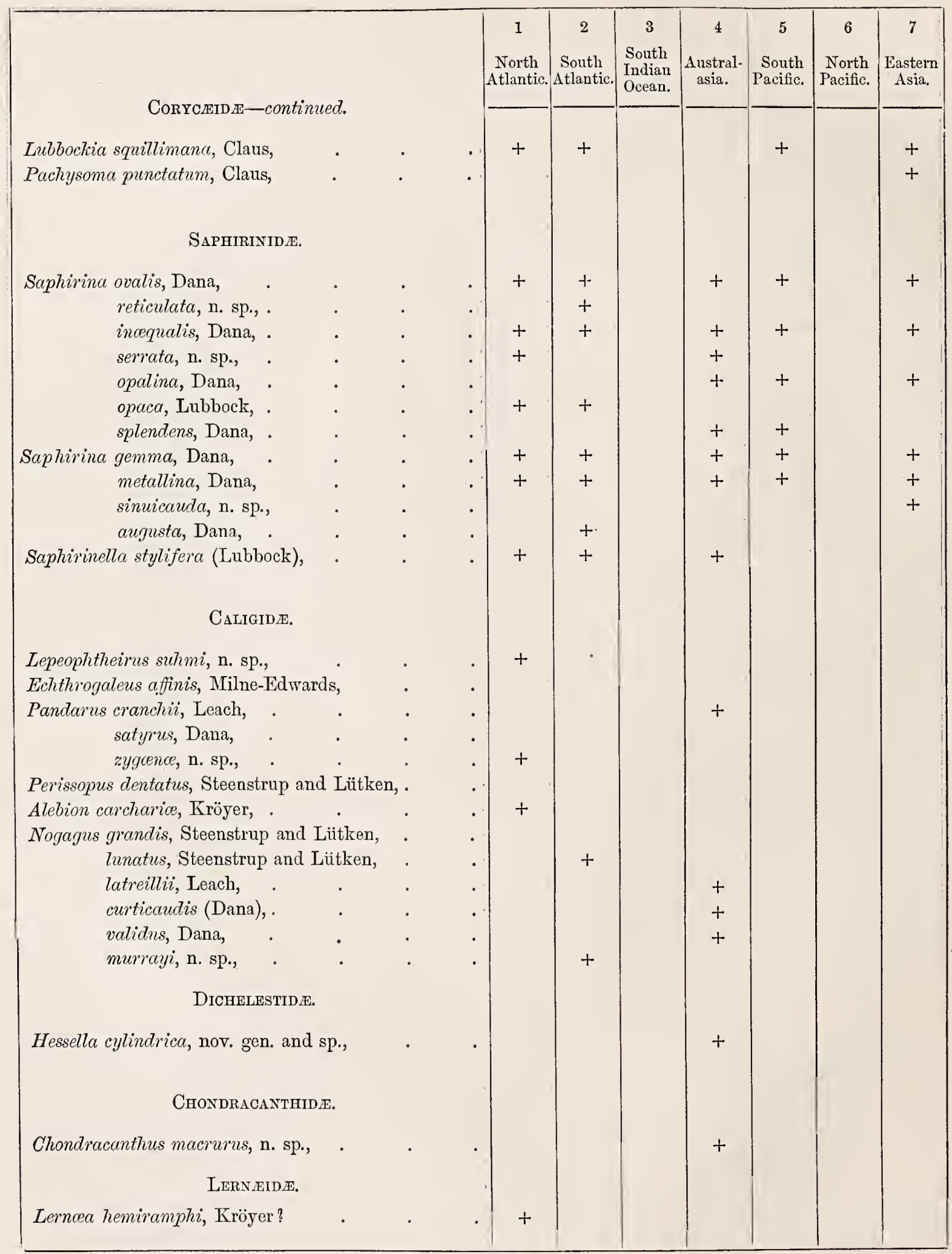




\section{LIST OF THE PRINCIPAL LOCALITIES FROM WHICH COPEPODA WERE TAKEN, WITH THE NAMES OF THE SPECIES FOUND IN EACH.}

Except where otherwise stated, all these gatherings were made during the daytime by means of the surface-net.

Station 45.-May 3, 1873 . Lat. $38^{\circ} 34^{\prime}$ N., long. $72^{\circ} 10^{\prime} \mathrm{W}$. Depth 1240 fathoms. Bottom temperature, $2^{\circ} \cdot 4$ C. Mud (dredge).

Calanus princeps, n. sp.

Station 50.-May 21, 1873 . Lat. $42^{\circ} 8^{\prime} \mathrm{N}$., long $63^{\circ} 39^{\prime} \mathrm{W}$. Depth 1250 fathoms.

Bottom temperature, $2^{\circ} \cdot 8 \mathrm{C}$. Grey ooze (dredge).

Calanus Princeps, n. sp.

May 22, 1873. Lat. $41^{\circ} 19^{\prime} \mathrm{N}$., long. $63^{\circ} 12^{\prime} \mathrm{W}$. South of Halifax, Nova Scotia.

Saphirina opaca, Lubbock.

Station 99.-August 15, 1873 . Lat. $7^{\circ} 53^{\prime}$ N., long. $17^{\circ} 26^{\prime}$ W. ; also August 17, 1873. Miracia efferata, Dana.

August 22-27, 1873. Mid-Atlantic, about $2^{\circ}$ north of the Equator.

Calanus gracilis, Dana.

Eucalanus attenuatus, Dana.

Lenckartia ?

Undina vulgaris, Dana.

Scolecithrix dano (Lubbock).

Euchota prestandrece, Philippi.

Temora dubia (Lubbock).

Candace pachydactyla, Dana.

Corycaus speciosus, Dana.

Copilia mirabilis, Dana.

Saphirinella stylifera (Lubbock).

August 25,1873 . Lat. $1^{\circ} 47^{\prime}$ N., long. $24^{\circ} 26^{\prime}$ W. 40 fathoms.

Undina vulgaris, Dana.

Euchoeta prestandrea, Philippi. 
October 5, 1873 . Lat. $29^{\circ} 1^{\prime}$ S., long. $28^{\circ} 59^{\prime} \mathrm{W}$. Night.

Pontella acutifrons (Dana). strenua (Dana).

Station 132.-October 10, 1873 . Lat $35^{\circ} 25^{\prime}$ S., long. $23^{\circ} 40^{\prime} \mathrm{W}$.

Saphirina reticulata, n. sp.

Saphivinella stylifera (Lubbock).

Station 144.-December 24, $1873 . \quad$ Lat. $45^{\circ} 57^{\prime}$ S., long. $34^{\circ} 39^{\prime} \mathrm{E}$.

Atidius armatus, nov. gen. and sp.

Rhincalanus gigas, n. sp.

Station 146.-December 29, 1873 . Lat. $46^{\circ} 46^{\prime}$ S., long. $45^{\circ} 31^{\prime} \mathrm{E}$.

Calanus propinquus, n. sp.

Eucalanus attenuatus, Dana.

Hemicalanus aculeatus, n. sp.

Heterochata spinifions, Claus.

Scolecithrix minor, n. gen. and sp.

Euchata prestandrea, Philippi.

AEtidius armatus, n. gen. and sp.

Candace truncata, Dana.

January 1, $1874 . \quad$ Lat. $46^{\circ} 45^{\prime}$ S., long. $50^{\circ} 42^{\prime}$ E. Off Crozets.

Drepanopus pectinatus, $n$. gen. and sp. (a large gathering, consisting almost entirely of this one species, all females).

Station 149.-January 9, 1874 . Lat. $49^{\circ} 16^{\prime}$ S., long. $70^{\circ} 12^{\prime}$ E. Betsy Cove, Kerguelen Island.

Drepanopus pectinatus, n. gen. and sp. (this gathering, like the preceding, contained only one species in great abundance).

January 23, 1874. Lat. $48^{\circ} 42^{\prime} \mathrm{S}$., long. $70^{\circ} 2^{\prime} \mathrm{W}$. Off Kerguelen Island.

Calconus propinquus, n. sp. (also a gathering consisting entirely of a single species).

January 25, 1874. Betsy Cove, Kerguelen Island.

Pseudothalestris imbricata, n. gen. and sp.

Zaus spinatus, Goodsir.

Machairopus idyoides, n. gen. and sp. 
Station 153.-February 14, 1874 . Lat. $65^{\circ} 42^{\prime}$ S., long. $79^{\circ} 49^{\prime}$ E.

Rhincalanus gigas, $\mathrm{n}$. sp.

February 14, 1874. Lat. $65^{\circ} 42^{\prime}$ S., long. $79^{\circ} 49^{\prime}$ E. Near the Ice Barrier, 100 fathoms.

Pleuromma abdominale (Lubbock).

February 16, 1874. Lat. $66^{\circ} 29^{\prime}$ S., long. $78^{\circ} \mathrm{W}$. Near the Ice Barrier. Saphirinella stylifera (Lubbock).

Station 154.-February 19, 1874. Lat. $64^{\circ} 37^{\prime}$ S., long. $85^{\circ} 49^{\prime}$ E.

Calanus propinquus, n. sp.

Rhincalanus gigas, $\mathrm{n}$. sp.

Pleuromma abdominale (Lubbock).

Candace truncata, Dana.

(The first three species occur also in gatherings made on the 20th and 21st of February.)

Station 158.-March 7, 1874 . Lat. $50^{\circ} 1^{\prime}$ S., long. $123^{\circ} 4^{\prime}$ E.

Heterochata spinifrons, Claus.

Etidius armatus, n. gen. and sp.

Station 159.-March 10, 1874. Lat $47^{\circ} 25^{\prime}$ S., long. $130^{\circ} 32^{\prime}$ E.

Calanus propinquus, $\mathrm{n}$. sp.

Eucalanus attenuatus (Dana).

Rhincalanus gigas, $\mathrm{n}$. sp.

Pleuromma abdominale (Lubbock).

Leuckartia flavicornis (?) Claus.

Euchceta prestandrea, Philippi.

March 15, 1874. Lat. $39^{\circ} 48^{\prime}$ S., long. $140^{\circ} 40^{\prime}$ E. South of Australia.

Calanus propinquus, nov. sp.

Centropages violaceus (Claus).

Saphirina ovalis, Dana.

April 3, 1874. Lat. $38^{\circ} 7^{\prime}$ S., long. $149^{\circ}$ i $8^{\prime}$ E. Off Cape Howe, Australia. In surface-net at night,

Calanus finmarchicus (Günner). valgus, n. sp.

Pleuromma abdominale (Lubbock).

(ZOOL. CHALL, EXP.-PART XXIII.-1883.) 
Undina vulgaris, Dana.

darwinii, Lubbock.

Drepanopus furcatus, n. gen. and sp.

Temora dubia (Lubbock).

Centropages violaceus (Claus).

Candace pectinata, Brady.

Oncrea obtusa (Dana).

April 1874 About lat. $39^{\circ} 10^{\prime}$ S., long. $146^{\circ} 37^{\prime}$ E. Bass Strait, off Mindanao.

Acartia denticornis, nov. sp.

Candace pectinata, Brady.

Setella gracilis, Dana.

Corycaus varius, Dana.

Oncaea obtusa (Dana).

Copitia mirabilis, Dana.

Saphirina ovalis, Dana.

June 8, 1874. Sydney Cove, Port Jackson, Australia. Daytime.

Undina vulgaris, Dana.

darwinii, Lubbock.

Scolecithrix dance (Lubbock).

Temora dubia (Lubbock).

Centropages furcatus (Dana).

Candace pachydactyla, Dana.

Pontella acuta (Dana).

Corycaus varius, Dana.

Oncaea obtusa (Dana).

Saphirina splendens, Dana.

June 8, 1874. Sydney Cove, Port Jackson, Australia. At night.

Calanus gracilis, Dana.

Eucalanus attenuatus (Dana).

Pleuromma abdominale (Lubbock).

Undina vulgaris, Dana.

darwinii, Lubbock.

Leuckartia flavicornis, Claus.

Temora dubia (Lubbock).

Etidius armatus, n. gen. and sp.

Candace pectinata, Brady. 
Pontella acutifions (Dana).

plumata (Dana).

Oithona challengerii, Brady.

Coryccens varius, Dana.

Oncrea obtusa (Dana).

Saphirina incequalis, Dana.

Station 164.-June 12, 1874 . Lat. $34^{\circ} 8^{\prime}$ S., long. $152^{\circ} 0^{\prime}$ E. Off Port Jackson.

Calanus tonsus, n. sp.

Atidius armatus, n. gen. and sp.

Undina vulgaris, Dana.

Temora dubia (Lubbock).

Station 164 B.-June 14, 1874 . Lat. $34^{\circ} 3^{\prime}$ S., long. $152^{\circ} 20^{\prime}$ E. Between Sydney and Wellington.

Calanus valgus, n. sp.

Eucalanus attenuatus (Dana).

setiger, n. sp.

Undina vulgaris, Dana.

darwinii, Lubbock.

Temora dubia (Lubbock).

Candace pectinata, Brady.

Euchceta prestandrece, Philippi.

Corycaus varius, Dana.

venustus, Dana.

Oncrea obtusc (Dana).

Station 165.-June, 17, 1874 . Lat. $34^{\circ} 50^{\prime}$ S., long. $155^{\circ} 28^{\prime}$ E. Between Sydney and Wellington.

Undina darwinii, Lubbock.

Candace pachydactyla, Dana.

Corycceus varius, Dana.

Oncaea obtusa, Dana.

August 11, 12, 1874. About lat. $19^{\circ}$ S., long. $177^{\circ} 10^{\prime}$ E. Off Kandavu, Fiji.

Calanus gracilis, Dana.

Eucalanus attenuatus (Dana).

Pleuromma abdominale (Lubbock). ${ }^{1}$

I This species constitutes the bulk of the gathering. 
Undina vulgaris, Dana.

Heterochatc spinifrons, Claus.

Leuckartia flavicornis (?) Claus.

Scolecithrix danoe (Lubbock).

Temora dubia (Lubbock).

Euchota prestandrece, Philippi.

Candace pachydactyla, Dana. truncata, Dana.

Calanopia elliptica, Dana.

Pontella plumata (Dana).

Corycceus varius, Dana.

Copilia mirabilis, Dana.

Onceea obtusa, Dana.

Saphirina incequalis, Dana. opalina, Dana.

Saphirinella stylifera (Lubbock).

August 25, 26, 1874. About lat. $13^{\circ} 30^{\prime}$ S., long. $150^{\circ}$ E. Between Api, New Hebrides, and Cape York, Australia.

Calanus gracitis, Dana.

Eucalanus attenuatus (Dana).

Pleuromma abdominale (Lubbock).

Undina darwinii, Lubbock. vulgaris, Dana.

Scolecithrix dance (Lubbock).

Temora dubia (Lubbock).

Euchata prestandrea, Philippi.

hessei, n. sp.

australis, n. sp.

Cadnace truncata, Dana. pectinata, Brady.

Pontella acutifrons (Dana). plumata (Dana).

Corycceus varius, Dana. venustus, Dana.

Copilia mircubilis, Dana.

Oncaea obtusa, Dana.

Saphirina ovalis, Dana. incequalis, Dana. 
Station 181.-August 25, 1874 . Lat. $13^{\circ} 50^{\prime}$ S., long. $151^{\circ} 49^{\prime}$ E.

Eucalanus attenuatus (Dana).

Pleuromma abdominale (Lubbock).

Undina vulgaris, Dana.

Euchota prestandrece, Philippi.

Temora dubia (Lubbock).

Pontella acutifrons (Dana).

Setella gracilis, Dana.

Corycaeus varius, Dana.

Copilia mirabilis, Dana.

Oncoec obtusa, Dana.

Saphirina serrata, n. sp.

September 2, 1874. Port Albany, Cape York, Australia.

Eucalanus attenuatus (Dana).

Hemicalanus orientalis, n. sp.

Undina vulgaris, Dana.

darwinii, Lubbock.

Scolecithrix dano (Lubbock).

Euchoeta prestandrece, Philippi.

Acartia laxa, Dana.

Pontella plumata (Dana).

Oncrea obtusa (Dana).

Saphirina ovalis, Dana.

September 13, 1874. Lat. $8^{\circ} 18^{\prime}$ S., long. $135^{\circ} 7^{\prime}$ E. Arafura Sea.

Calanus valgus, n. sp.

Eucalanus setiger, n. sp.

Undina vulgaris, Dana.

Euchata prestandrea, Philippi.

Temora dubia (Lubbock).

Centropages furcatus (Dana).

Pontella acuta (Dana).

kröyeri, n. sp.

Station 198.-October 20, $1874 . \quad$ Lat. $2^{\circ} 55^{\prime}$ N., long. $124^{\circ} 53^{\prime} \mathrm{E}$.

Eucalanus attenuatus (Dana).

Euchoeta prestandrea, Philippi. 
Candace truncata, Dana.

Oithona challengerii, n. sp.

Corycaus varius, Dana.

Oncaea obtusa, Dana.

Saphirina metallina, Dana.

Station 200.-October 23, 1874 . Lat. $6^{\circ} 48^{\prime}$ N., long. $122^{\circ} 25^{\prime}$ E. Net at 80 fathoms. Daytime.

Eucalanus attenuatus (Dana).

setiger, n. sp.

Rhincalanus cornutus, Dana.

Undina vulgaris, Dana. darwinii, Lubbock.

Temora dubia (Lubbock).

Candace truncata, Dana.

Corynura gracilis, n. gen. and sp.

Calanopia elliptica, Dana.

Pontella acuta (Dana).

lavidentata, n. sp.

kröyeri, n. sp.

elephas, n. sp.

Corycaus varius, Dana.

Lubbockia squillimana, Claus.

Copitia mirabilis, Dana.

Saphirina incequalis, Dana.

October 23, 1874 . Lat. $6^{\circ} 47^{\prime} \mathrm{N}$., long. $122^{\circ} 28^{\prime} \mathrm{W}$.

Temora dubia (Lubbock).

Corycaus varius, Dana.

Copilia mirabilis, Dana.

October 25, 1874. Off Zamboanga, Philippine Islands.

Eucalanus setiger, n. sp.

Undina vulgaris, Dana.

Temora dubia (Lubbock).

Acartia denticornis, n. sp.

Corynura gracilis, n. gen. and sp.

Calanopia elliptica, Dana. 
Pontella acuta (Dana).

kröyeri, n. sp.

elephas, in. sp.

Saphirina ovalis, Dana.

Station 201.-October 26, 1874. Lat. $7^{\circ} 3^{\prime}$ N., long. $121^{\circ} 48^{\prime}$ E. Net at 88 fathoms.

Undina vulgaris, Dana.

darwinii, Lubbock.

Euchceta prestandrece, Philippi.

Copitia mirabitis, Dana.

Saphirina ovalis, Dana.

November 12, 1874 . Lat. $15^{\circ} 8^{\prime}$ N., long. $119^{\circ} 49^{\prime} \mathrm{E}$.

Eucalanus attenuatus (Dana).

Undina darwinii, Lubbock.

Scolecithrix dano (Lubbock).

Euchoeta prestandrea, Philippi.

Candace truncata, Dana.

January 18-23, 1875. Zebu Harbour, Philippine Islands.

Eucalanus attenuatus (Dana).

Eucalanus setiger, n. sp.

Euchata prestandrea, Philippi.

Undina vulgaris, Dana.

Acartia laxe, Dana.

Corynura barbata, n. gen. and sp.

Temora dubia (Lubbock).

Calanopia elliptica, Dana.

January 29-February 3, 1875 . Off Zamboanga, Philippine Islands.

Undina vulgaris, Dana.

Euchata prestandrea, Philippi.

Temora dubia (Lubbock).

Acartia laxa, Dana.

Corynura gracitis, n. gen. and sp.

Setella gracilis, Dana.

Copilia mirabilis, Dana.

Pachysoma punctatum, Claus. 
Oithona spinirostris (?) Claus.

Corycceus varius, Dana.

limbatus, n. sp.

Onceea obtusa, Dana.

Station 206.—January 8, 1875 . Lat. $17^{\circ} 54^{\prime}$ N., long. $117^{\circ} 14^{\prime} \mathrm{E}$.

Calamus gracilis, Dana.

Eucalanus attenuatus (Dana).

Rhincalanus cornutus, Dana.

Undina darwinii, Lubbock.

Scolecithrix dance (Lubbock).

Euchceta prestandrece, Philippi.

Temora dubia (Lubbock).

Etidius armatus, n, gen. and sp.

Candace truncata, Dana.

Oithona challengerii, n. sp.

Corycceus varius, Dana.

venustus, Dana.

Saphirina metallina, Dana.

opalina, Dana.

January 9, 1875 . Lat. $16^{\circ} 35^{\prime}$ N., long. $117^{\circ} 47^{\prime}$ E.

Calanus gracilis, Dana.

Eucalanus attenuatus (Dana).

setiger, n. sp.

Rhincalanus cornutus, Dana.

gigas, n. sp.

Undina darwinii, Lubbock.

Scolecithrix dance (Lubbock).

Euchata prestandrea, Philippi.

hessei, n. sp.

Centropages violaceus (Claus).

Candace pectinata, Brady.

truncata, Dana.

Corycceus varius, Dana.

venustus, Dana.

Copilia mirabilis, Dana.

Onceea obtusa (Dana).

Saphirina opalina, Dana. 
February 1875. On the Equator, about long. $140^{\circ}$ E. North of P.apua.

Undina vulgaris, Dana.

darvinii, Lubbock.

Pontella plumata (Dana).

Setella gracilis, Dana.

Onceea obtusc (Dana).

Copilia mirabilis, Dana.

Saphirina opalina, Dana. ovalis, Dana.

February 5, 1875 . Zamboanga, Philippine Islands.

Eucalanus setiger, n. sp.

Undina vulgaris, Dana.

Temorc dubia (Lubbock).

Centropages furcatus (Dana).

Candace truncata, Dana.

Acartia laxa, Dana.

Corynura gracilis, n. gen. and sp.

Calanopia elliptica, Dana.

Pontella kröyeri, n. sp.

elephas, n. sp.

Corycceus varius, Dana.

venustus, Dana.

Onceece obtusce (Dana).

Saphirina ovalis, Dana.

sinuicauda, n. sp.

February 6, 1875 . Lat. $6^{\circ} 40^{\prime}$ N., long. $122^{\circ} 57^{\prime}$ E. Near Zamboanga.

Eucalanus attenuatus (Dana).

setiger, n. sp.

Undina vulyaris, Dana.

darwinii, Lubbock.

Scolecithrix dance (Lubbock).

Euchoeta prestandree, Philippi.

Candace pachydactyla, Dana.

Calanopia elliptica, Dana.

Corynura gracilis, n. gen. and sp.

Pontella acuta (Dana).

plumatce (Dana).

acutifrons (Dana).

(ZOOL. CHALL. EXP.--PART XXIII.-1883.) 
Setella gracilis, Dana.

Corycceus varius, Dana. venustus, Dana.

Oncrea obtusa (Dana).

Saphivina ovalis, Dana. incequalis, Dana.

sinuicauda, n. sp.

February 1875. About lat. $4^{\circ}$ N., long. 130 E. West of Papua.

Scolecithrix dane (Lubbock).

Euchata prestandrea, Philippi.

Leuckartia flavicornis (?) Claus.

Setella gracilis, Dana.

Onccea obtusa (Dana).

Corycaus sp.

April 3, 1875 . Lat. $24^{\circ} 49^{\prime}$ N., long. $138^{\circ} 34^{\prime}$ E.

Euchota hossei, n. sp.

Pontclla plumata (Dana).

detruncata (Dana).

Inland Sea, Japan.

Coryccus obtusus, Dana.

Station 237.-June 17, 1875 . Lat. $34^{\circ} 37^{\prime}$ N., long. $140^{\circ} 32^{\prime}$ E.

Eucalanus setiger, n. sp.

Scolecithrix dana (Lubbock).

Candace pectinata, Brady.

Euchata prestandrece, Philippi.

Oncaea obtusa (Dana).

Station 241._June 23, 1875 . Lat. $35^{\circ} 41^{\prime}$ N., long. $157^{\circ} 42^{\prime}$ E.

Calanus propinquus, n. sp.

July 1875. About lat. $35^{\circ}$ N. Between Japan and Honolulu.

Rhincalanus gigas, n. sp.

Euchata prestandrece, Philippi.

hessci, n. sp.

Leuckartia scopularis, n. sp. 
Station 256.-July 21, 1875 . Lat. $30^{\circ} 22^{\prime}$ N., long. $154^{\circ} 56^{\prime} \mathrm{W}$.

Pleuromma abclominale (Lubbock).

Undina vulgaris, Dana.

darwinii, Lubbock.

Euchceta prestandrece, Philippi.

Centropages violaceus (Claus).

Candace truncata, Dana.

Pontella acutifions (Dana).

detruncatu (Dana).

Pontellopsis villosa, n. gen. and sp.

Setella gracitis, Dana.

Corycceus varius, Dana.

Oncrea obtusa (Dana).

Station 257.-July 23, 1875 . Lat. $27^{\circ} 33^{\prime}$ N., long. $154^{\circ} 55^{\prime}$ W. “Deep haul."

Hemicalanus aculeatus, n. sp.

August 16, 1875 . Hilo Harbour.

Acartia denticornis, n. sp.

Candace pachydactyla, Dana.

Scolecithrix dance (Lubbock).

Pontella plumata (Dana).

Oithona challengeri, n. sp.

Lubbockia squillimana, Claus.

Onceea obtusa (Dana).

Saphirina ovalis, Dana.

metallina, Dana.

Station 268.-August 30, 1875 . Lat. $7^{\circ} 35^{\prime}$ N., long. $140^{\circ} 49^{\prime} \mathrm{W}$.

'Eucalanus attenuatus (Dana).

Undina darwinii, Lubbock.

Scolecithrix dance (Lubbock).

Eucheta prestandrece, Philippi.

Oithona, sp.

Onceec obtusa (Dana). 
October 18,1875 . Lat. $36^{\circ} 0^{\prime}$ S., long. $132^{\circ} 22^{\prime} \mathrm{W}$.

Pleuromma abdominale (Lubbock).

Undina darwinii, Lubbock.

Centropages violaceus (Claus).

Corycceus varius, Dana.

Station 287.-October 19, 1875. Lat. $36^{\circ} 32^{\prime}$ S., long. $132^{\circ} 52^{\prime} \mathrm{W}$.

Calanus finmarchicus (Günner).

valgus, n. sp.

Pleuromma abdominale (Lubbock).

Undina darwinii, Lubbock.

Euchata hessei, n. sp.

Corycaus varius. Dana.

Saphirina ovalis, Dana.

Station 288.-October 21, 1875 . Lat. $40^{\circ} 3^{\prime}$ S., long. $132^{\circ} 58^{\prime} \mathrm{W}$.

Calanus propenquus n. sp. valgus, n. sp.

Hemicalanus longicornis, Claus.

Pleuromma abdominale (Lubbock).

Heterochceta spinifions, Claus.

Centropages violaceus (Claus).

Euchata philippii, n. sp.

Leuckartia flavicornis (?) Claus.

Lubbockia squillimana, Claus.

Miracia efferata, Dana.

October 22,1875 . Lat. $40^{\circ} 0^{\prime}$ S., long. $131^{\circ} 36^{\prime} \mathrm{W}$.

Calanus tonsus, n. sp.

Pleuromma abdominale (Lubbock).

November 6, 1875 . Lat. $37^{\circ} 50^{\prime}$ S., long. $93^{\circ} 54^{\prime} \mathrm{W}$.

Calanus valgus, n. sp.

Euchceta hessei, n. sp.

Station 296.-Nov. 9, 1875 . Lat. $38^{\circ} 6^{\prime}$ S., long. $88^{\circ} 2^{\prime} \mathrm{W}$.

Calanus valgus, n. sp.

tonsus, n. sp. 
December 5, 1875. Off Valparaiso.

Calanus propinquus, n. sp.

Undina darwinii, Lubbock.

Corycaus rostratus, Claus.

Oncrea obtusa, Dana.

December 8, 1875. Off Valparaiso.

Calanus gracilis, Dana.

Eucalanus attenuatus (Dana).

Drepanopus furcatus, n. gen. and sp.

Station 299.-December 14, 1875. Lat. $33^{\circ} 31^{\prime}$ S., long. $74^{\circ} 43^{\prime} \mathrm{W}$. Net at 20 fathoms.

Calanus valgus, n. sp.

Drepanopus furcatus, $\mathrm{n}$. gen. and sp.

Saphirina gemma, Dana.

splendens, Dana.

incequalis, Dana.

Station 302.-December 28, 1875 . Lat. $42^{\circ} 43^{\prime}$ S., long. $82^{\circ} 11^{\prime} \mathrm{W}$.

Calanus tonsus, n. sp.

Undina darwinii, Lubbock.

Centropages violaceus (Claus).

Euchata prestandrea, Philippi.

Onccea obtusa (Dana).

Station 303.-December 30, 1875 . Lat. $45^{\circ} 31^{\prime}$ S., long. $78^{\circ} 9^{\prime} \mathrm{W}$.

Eucalanus attenuatus (Dana).

Station 304.-December 31, 1875 . Lat. $46^{\circ} 53^{\prime}$ S., long. $75^{\circ} 12^{\prime} \mathrm{W}$.

Pleuromma abdominale (Lubbock).

Calanoides patagoniensis, n. gen. and sp.

Centropages bracliatus (Dana).

January 1876. Straits of Magellan.

Pleuromma abdominale (Lubbock).

Acartia denticornis (?) n. sp.

Centropages brachiatus (Dana). 
Station 318.-Feb. 1], 1876 . Lat. $42^{\circ} 32^{\prime}$ S., long. $56^{\circ} 29^{\prime}$ W. Net at 30 fathoms. Goniopsyllus rostratus, n. gen. and sp.

Oithona challengeri, Dana.

Corycaus varius, Dana.

Station 319.-February 12, 1876 . Lat. $41^{\circ} 54^{\prime}$ S., long $54^{\circ} 48^{\prime} \mathrm{W}$.

Saphirina reticulata, n. sp.

opaca, Lubbock.

ovalis, Dana.

incequalis, Dana.

Station 320.-February 14, 1876. Lat. $37^{\circ} 17^{\prime}$ S., long. $53^{\circ} 52^{\prime} \mathrm{W}$.

Rhincalanus gigas, n. sp.

Calanus propinquus, n. sp.

Pleuromma abdominale (Lubbock).

Heterochata spinifrons Claus.

Station 324.-February 29, 1876. Lat. $36^{\circ} 9^{\prime}$ S., long. $48^{\circ} 22^{\prime} \mathrm{W}$.

Calanus tonsus, n. sp.

$$
\text { valgus, n. sp. }
$$

Acartia denticornis, n. sp.

Pontella detruncata (Dana).

Saphivina incequalis, Dana.

STítion 325.-March 2, 1876. Lat. $36^{\circ} 44^{\prime}$ S., 'long $46^{\circ} 16^{\prime}$ W. Depth 2650 fathoms. Dredge.

Calanus tonsus, n. sp.

Rhincalanus gigas, n. sp.

Pleuromma abdominale (Lubbock).

Heterochceta spinifrons, Claus.

Lenckartia flaviconis, Claus.

Euchata prestandra, Philippi.

australis, n. sp.

philippii, n. sp.

gigas, n. sp.

barbata, n. sp.

Phyllopus bidentatus, n. gen. and sp.

Oncrea obtusa (Dana). 
Station 325.-March 2, 1876 . Lat. $36^{\circ} 44^{\prime}$ S., long. $46^{\circ} 16^{\prime}$ W. Surface net.

Undina darwinii, Lubbock.

Setella gracilis, Dana.

Corycaeus rostratus, Claus.

Oncaea obtusa (Dana).

Station 326.-March 3, 1876 . Lat. $37^{\circ} 3^{\prime}$ S., long. $44^{\circ} 17^{\prime} \mathrm{W}$.

Temora dubia (Lubbock).

Centropages violaceus (Claus).

Corycceus varius, Dana.

Saphinina incequalis, Dana.

March 3-5, 1876. About lat. $37^{\circ} 15^{\prime}$ S., long. $43^{\circ} 0^{\prime} \mathrm{W}$.

Calanus valgus, n. sp.

Centropages violaceus (Claus).

Candace pachydactyla, Dana.

Pontellopsis villosa, n. sp.

Oncaea obtusa (Dana).

Station 330.-March 8, 1876 . Lat. $37^{\circ} 45^{\prime}$ S., long. $33^{\circ} 0^{\prime} \mathrm{W}$.

Pleuromma abdominale (Lubbock).

Heterochceta spinifrons, Claus.

Station 332.-March 10, 1876 . Lat. $37^{\circ} 29^{\prime}$ S., long. $27^{\circ} 31^{\prime}$ W. Depth 2200 fathoms. Tow-net at trawl.

Pontostratiotes abyssicola, n. gen. and sp.

One specimen only taken.

Station 335.-March 16, 1876 . Lat. $32^{\circ} 24^{\prime}$ S., long. $13^{\circ} 5^{\prime} \mathrm{W}$

Scolecithrix dance (Lubbock).

Etidius armatus, n. gen. and sp.

Acartia denticornis, n. sp.

Oithona challengeri, n. sp.

Corycaus varius, Dana.

Saphirina ovalis, Dana.

angusta, Dana. 
Station 341.-March 25, 1876 . Lat. $12^{\circ} 16^{\prime}$ S., long. $13^{\circ} 44^{\prime} \mathrm{W}$.

Euchceta prestandrece, Philippi.

Oithona challengeri, n. sp. spinirostris (?), Claus.

Corycceus varius, Dana.

limbatus, n. sp.

Lubbockia squillimana, Claus.

Station 342.-March 26, 1876 . Lat. $9^{\circ} 43^{\prime}$ S., long. $13^{\circ} 51^{\prime} \mathrm{W}$.

Calanus propinquus, n. sp. gracilis, Dana.

Undina vulgaris, Dana.

Scolecithrix dance (Lulbbock).

Euchata prestandrece, Philippi.

Centropages violaceus (Claus).

Candace truncata, Dana.

Oithona challengeri, n. sp.

Setella gracilis, Dana.

Corycceus varius, Dana. rostratus, Claus.

Copilia mirabilis, Dana.

Lubbockia squillimana, Claus.

Onceea obtusa, Dana.

Station 348.-April 9, 1876 . Lat. $3^{\circ} 10^{\prime}$ N., long. $14^{\circ} 5 \mathrm{I}^{\prime} \mathrm{W}$.

Culanus gracilis, Dana. valgus, it. sp.

Heterochata spinifrons, Claus.

Undina vulgaris, Dana.

Scolecithrix dance (Lubbock).

Euchata prestandrea, Philippi.

Drepanopus furcatus, n. gen. and sp.

Etidius armatus, n. gen. and sp.

Temora dubia (Lubbock).

Candace pectinata, Brady. pachydactyla, Dana.

Setella gracitis, Dana. 
Corycceus varius, Dana. rostratus, Claus.

Saphivina metallina, Dana.

Oncaea obtusa, Dana.

Station 348.-April 9, 1876 . Lat. $3^{\circ} 10^{\prime}$ N., long. $14^{\circ} 51^{\prime} \mathrm{W}$. Net to 200 fathoms.

Calanus gracilis, Dana.

propinquus, n. sp.

Eucalanus attenuatus (Dana).

Undina vulgaris, Dana.

Euchata prestandrece, Philippi.

Candace pachydactyla, Dana.

Oithona challengeri, n. sp.

Ectinosoma atlanticum (B. and R.).

Setella gracitis, Dana.

Corycceus varius, Dana.

venustus, Dana.

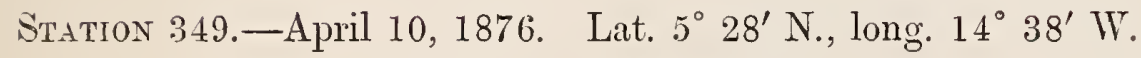

Calanus gracilis, Dana.

Eucalanus attenuatus (Dana).

Rhincalanus cornutus, Dana.

Pleuromma abdominale (Lubbock).

Undina vulgaris, Dana.

Scolecithrix dance (Lubbock).

Euchceta prestandrea, Philippi.

Drepanopus furcatus, n. gen. and sp.

Temora dubia (Lubbock).

Candace pectinata, Brady.

Oithona challengeri, n. sp.

Miracice efferctce, Dana.

Corycaus varius, Dana.

Copilia mirabilis, Dana.

Lubbockia squillimana, Claus.

Oncaec obtusa (Dana).

Saphirina ovalis, Dana.

Saphirinella stylifera (Lubbock).

(ZOOL. CHALI. EXP.-PART XXIII-1883.) 
Station 350.-April 11, 1876 . Lat. $7^{\circ} 33^{\prime}$ N., long. $15^{\circ} 16^{\prime} \mathrm{W}$. Eucalanus attenuatus (Dana). setiger, n. sp.

Undina vulgaris, Dana.

Heterochceta spinifrons, Claus.

Leuckartic fluvicornis, Claus.

Scolecithrix dance (Lubbock).

Eucheta prestandrece, Philippi.

Temora dubia (Lubbock).

Acartice laxe, Dana.

Candace pectinata, Brady.

Oithona challengeri, n. sp.

Corycaus varius, Dana.

Onccea obtusa, Dana.

Miracice efferata, Dana.

Saphirina incequalis, Dana.

Station 351.-April 12, 1876 . Lat. $9^{\circ} 9^{\prime}$ N., long. $16^{\circ} 41 \mathrm{~W}$.

Calanus gracilis, Dana.

Eucalanus attenuatus (Dana).

Undina vulgaris, Dana.

Scolecithrix dance (Lubbock).

Euchata prestandrea, Philippi.

Leuckartia flavicornis, Claus.

Temora dubia (Lubbock).

Candace pectinata, Brady.

Oithona challengeri, n. sp.

Setella gracilis, Dana.

Corycceus varius, Dana.

Oncaec obtusce (Dana).

Lubbockia squillimana, Claus.

Saphirina metallina, Dana.

Station 352.-April 13, 1876 . Lat. $10^{\circ} 55^{\prime} \mathrm{N}$., long. $17^{\circ} 46^{\prime} \mathrm{W}$.

Undina vulgaris, Dana.

Scolecithrix dance (Lubbock).

Euchata prestandrece, Philippi.

hessei, n. sp. 
Temora dubia (Lubbock).

armata, Claus.

Leuckartia flavicomis, Claus.

Candace pectinata, Brady.

Acartia laxa, Dana.

Oithona challengeri, n. sp.

Miracia efferata, Dana.

Corycaus varius, Dana.

Copilia mirabilis, Dana.

Saphirina incequalis, Dana.

April 26, 1876. St. Vincent, Cape Verde Islands.

Eucalanus setiger, n. sp.

Pleuromma abdominale (Lubbock).

Undina vulgaris, Dana.

Temora dubia (Lubbock).

Candace pectinata, Brady.

Pontella detruncata (Dana). acutifrons (Dana).

Corycceus rostratus, Claus.

Onccea obtusa (Dana).

Saphirina ovalis, Dana.

serrata, n. sp.

April 27, $1876 . \quad$ Lat. $17^{\circ} 18^{\prime}$ N., long. $26^{\circ} 32^{\prime} \mathrm{W}$.

Saphirina gemma, Dana.

April 28, 1876 . Lat. $17^{\circ} 47^{\prime} \mathrm{N}$., long. $28^{\circ} 28^{\prime} \mathrm{W}$.

Undina vulgaris, Dana.

Scolecithrix dance (Lubbock).

Euchata prestandrea, Philippi.

Candace pachydactyla, Dana.

Pontella acutifrons (Dana). strenua (Dana).

Saphirinella stylifera (Lubbock). 
April 29, $1876 . \quad$ Lat. $18^{\circ} 8^{\prime} \mathrm{N}$., long. $30^{\circ} 5^{\prime} \mathrm{W}$.

Calanus valgus, n. sp.

Undina vulgaris, Dana.

Scolecithrix dance (Lubbock).

Euchota prestandrea, Philippi.

Candace pachydactyla, Dana.

Saphirina ovalis, Dana.

Station 353.-May 3, 1876 . Lat. $26^{\circ} 21^{\prime}$ N., long. $33^{\circ} 37^{\prime} \mathrm{W}$.

Calanus gracitis, Dana.

Hemicalanus longicornis, Claus.

Pleuromma abdominale (Lubbock).

Heterochceta spinifrons, Claus.

Leuckartia flavicomis, Claus.

Undina daminii, Lubbock.

Scolecithrix dance (Lubbock).

Euchata prestandrea, Philippi.

Centropages violaceus (Claus).

Candace truncata, Dana.

pachydactyla, Dana.

Oithona challengeri, n. sp.

Corycaus varius, Dana.

venustus, Dana.

May 7, 1876. Lat. $34^{\circ} 22^{\prime}$ N., long. $34^{\circ} 23^{\prime} \mathrm{W}$. Atlantic.

Calanus gracitis, Dana.

Pleuromma abdominale (Lubbock).

Euchceta prestandrece, Philippi.

pulchra (Lubbock). 
Sub-Class ENTOMostraCA, Mïller (Gnathopoda, H. Woodward).

Order COPEPODA, Milne-Edwards.

Seetion I. GNA тн о о т о A, Thorell.

Family I. Calanide, Dana.

Body elongated, eonsisting of from ten to twelve segments. Abdomen nearly cylindrieal, mueh narrower than the eephalothorax, and prolonged at the posterior extremity into two more or less eylindrieal eaudal stylets. Head often eontinuous with the first segment of the thorax; fourth and fifth thoraeie segments often eoaleseent. Head rarely divided into two segments, but not unfrequently showing an ineomplete separation ("eervieal suture"). Anterior antennæ very long, and eomposed of twenty-two to twenty-five (rarely fifteen, eighteen, or twenty) joints; that of the right side in the male often modified for grasping. Posterior antennæ large, eomposed of a basal joint, to whieh are usually attaehed two branehes, the primary (extermal) eonsisting of two, the seeondary (internal) of several joints. Mandibles strongly toothed at the apex, palp usually two-branched. Maxillæ strong, eomposed of a more or less quadrate biting portion, whieh bears numerous eurved, setiform, marginal teeth, and a eomplex, many-lobed palp. Foot-jaws largely developed: anterior pair very broad, inner margins of the basal joints forming wart-like proeesses, from whieh spring long eiliated bristles; distal extremity livided into three short joints, whieh are beset with strong eiliated setæ; posterior pair longer and more slender, basal portion eomposed of two long and narrow joints, apieal portion usually of four to six very small joints. First four pairs of feet two-branehed, the outer branehes (in the adult) almost always three-jointed. Fifth pair either like the foregoing, or remarkably different, and forming in the male powerful elasping organs, whieh are unlike on the two sides: those of the female, though often differing from the true swimming feet, always alike on the two sides. A heart is present. Eyes either median and stalked, or paired (lateral) and sessile; in the latter ease often coaleseent, and eomposed of several lenses and pigment-masses : situated usually near the front of the head, but in one genus (Pleuromma) near the base of the foot-jaw of one side only. Sexual organs in the female symmetrieal, in the male asymmetrieal; ovisae single, borne in front of the abdomen.

This family ineludes by far the larger portion of the pelagie Copepoda, being represented abundantly in all seas, from the equator to the poles-or at any rate, as near to those points as seientific investigation lias yet been able to extend.

The overwhelming preponderanee of this family in the open sea is at onee apparent, when we note that out of the ninety speeies of free-living Copepoda found amongst 
the Challenger gatherings, fifty-eight belong to the Calanidæ. On the other hand, there can be little doubt that had it formed part of the plan of the expedition to investigate fully the littoral fauna of the countries visited, we should have found the proportionate number of species reversed for that zone in favour of the Harpacticidæ. The Calanidæ, indeed, by virtue of their enormously-developed anterior antennæ (often equalling, or more than equalling, in length the entire body of the animal), are specially adapted for an entirely natatory life, those organs when spread out at right angles to the body acting like the wings of a hovering bird, and so suspending the animal at almost perfect rest in the water. In the Harpacticidæ, on the contrary, we find antennæ usually so short that they ean be of very little use as swimming organs,---this function probably devolving almost entirely on the feet. And as a result of this structure, the members of the family launt chiefly either the muddy sand of the sea-bed, or littoral situations, where there is abundance of weed, on the fronds of which they rest and find their food, swimming only fitfully and by short jerks.

Following the classification adopted in my Monograph of the British Copepoda, ${ }^{1}$ I unite with the Calanidæ the species referred by Dr Claus to a separate family, Pontellidæ,distributing the Calanidæ under two sub-families,--Calaninæ and Pontellinæ.

The fifty-eight species of Calanidæ taken by the Challenger belong to the following genera:-Calanus, Eucalanus, Rhincalanus, Hemicalanus, Pleuromma, Heterochata, Leuckartia, Undina, Scolecithrix, Euchata, Calanoides, Atidius, Drepanopus, Phyllopus, Temora, Centropages, Candace, Acartia, Corynura, Calanopia, Pontellopsis, and Pontella.

\section{Sub-family I. CaLanin}

This sub-family is characterised by the presence of only one eye, which is sessile and made up of several lenses.

\section{Calanus, Leach.}

Calanus, Leach, Dict. Sci. Nat. XIV., Art. Entomostraca (1819); Dana, in part, Crust. U.S. Expl. Exped. (1852), Boeck, Oversigt Norges Copepoder (1864); Lubbock passim; Brady, Monog. Brit. Copep. (1878).

Cetochilus, Roussel de Vauzème, Claus, Baird, Goodsir.

Monoculus, Günner, Act. Hafn. (1765).

Cephalothorax elongated, slender, composed of five or six segments; head usually separate from the thorax, and often more or less distinetly divided near the middle by a transverse "cervical suture"; rostrum attenuated and bifid. Eyes small, situated at the back of the head, near the middle line, each composed of two lenses. Anterior antennæ long, composed of twenty-five joints, alike on the right and left sides in hoth

\footnotetext{
Ray Society, 1878.
} 
sexes, and possessing no hinge joint : those of the male are provided with thickened, clubshaped appendages, and the joints are often slightly narrowed at the base. Posteriorantennæ two-branched, the secondary branch having three or four small intercalated median joints. Maxilla composed of a broad masticating portion, which bears a series of stout, short setx, and a foliaceous, multifid palp made up of several digitiform segments, all of which bear numerous long and finely ciliated setæ. Mandibles large and strong, dilated and strongly toothed at the apex; basal joint of the palp large and widened towards the apex, from which spring two nearly equal branches, composed (usually) of two, and three or four, joints respectively. Anterior foot-jaws broad and strong, provided with several marginal processes which bear strong curved setæ; posterior foot-jaws elongated, composed of two large basal and five smaller apical joints, all of which bear long setæ. Five pairs of twobranched feet adapted for swimming, each branch composed of three joints; in the male, however, the outer branches of the fifth pair on one or both sides are somewhat modified. Abdomen of the male five, of the female four-jointed.

The genus Calanus was established by Leach for the reception of the species called by Müller, in his Entomostraca, Cyclops longicornis, and in the Zool. Dan. Prodr. Cyclops finmarchicus, and identified by that author with Günner's Monoculus finmarchicus. It is impossible to say certainly what is the species referred to in Müller's figure. The caudal part has, I think, undoubtedly been drawn from Temora finmarchica, Baird, while the antennæ are much too long for that species, and are probably taken from Cetochilus septentrionalis, Goodsir, which species seems also to be meant in the description :- "Antennæ,-corpore longiores." But Günner's figures, from the general contour of the animal, the length of the antennæ, and the characteristic long subapical setæe, certainly belong to Cetochilus septentrionalis. I therefore follow Boeck in assigning the generic term Calanus to the form originally described by Günner, discarding the later name Cetochilus. Baird's Temora finmarchica will in this case stand as the type of the genus Temora. In accordance with this view it is impossible to accept Dr. Baird's identification of his Temora finmarchica with Günner's species. And though the generic name Temora holds good, it seems best, considering the doubt which must rest upon the meaning of Müller's figure, to discard the name longicornis (adopted by Boeck and by myself in the Monograph of the British Copepoda-from Müller) and to accept that of longicaudata proposed in 1857 by Sir John Lubbock. I have thought it best to give in detail my reasons for this nomenclature, inasmuch as a different course is advocated by Dr. Claus, and, I think, by Giesbrecht.

As understood by Dana, this genus includes a great number of species properly referable to several distinet genera, notably to Calanus (proper), Hemicalanus, Eucalanus, and Temora, but it is not possible in many cases to assign Dana's species to their true position, the published details being insufficient for that purpose. The presence of five pairs of welldeveloped swimming feet in both sexes, and the peculiar modification of the fifth pair 
in the male, the twenty-five jointed anterior antennæ, together with the characters of the posterior antennæ and mouth-organs, are the characters upon which rest the claims of Calanus to generic rank. The species are probably very numerous, and are found near the surface of the sea in all parts of the world. In some species, though perhaps not in all, there is a remarkable difference between the posterior foot-jaws of male and female, those of the male being somewhat smaller, stouter, and armed on the outer margin, near the apex, with two or more stout and profusely plumose recurved setæ.

1. Calanus finmarchicus (Günner) (Pl. I. figs. 1-10).

Monoculus finmarchicus, Günner, Act. Hafn. x., 175, figs. 20-23 (1765).

Cetochilus septentrionalis, Goodsir, Edin. New Phil. Journ. 35, p. 339, t. vi. figs. 1-11 (1843).

, $\quad$ Baird, Nat. Hist. Brit. Entom., p. 235, t. xxx., figs. $1 a-g(1850)$.

" helgolandieus, Claus, Die frei lebenden Copepoden, p. 171, t. xxvi., figs. 2-9 (1863).

Calanus finmarchicus, Boeck, Oversigt over de ved Norges Kyster iagttagne Copepoder, p. 8 (1864), Brady, Monogr. of the Copepoda of the British Islands, vol. i. p. 38, pl. i. figs. 1-12 (1878).

Calanus magnus, borealis and elegans, Lubbock, Ann. Mag. Nat. Hist., ser. 2, vol. xiv. (1854).

Length, 1-7th of an inch $(3.5 \mathrm{~mm}.){ }^{1} \quad$ Forehead broadly rounded, rostrum long, slender and bifid, anterior antennæ twenty-five jointed, as long as the body, each joint bearing two or three short setæ (except those near the base in the female), the twenty-third and twenty-fourth joints each with a long apical seta; most of the joints of the male antenna (fig. 1) are constricted at the point of articulation, and bear fusiform or clubshaped appendages at the apices. The branches of the posterior antennæ (fig. 3) are stout and nearly equal; those of the mandible-palp (fig. 4) are short and nearly equal, one indistinctly four-jointed, the other two-jointed, with the first joint much swollen. The swimming feet are long and slender, terminal spines slender and without serratures (fig. 9), the first joint of the peduncle of the fifth pair, in both sexes, has its inner margin bordered with about fifteen sharp teeth of equal size throughout; the outer branch of the right side, in the male, has its first two joints much elongated (fig. 10), equalling in length the three joints of the left limb; the last joint is much shorter, ovate, and bears three or four small slender setæ near its apex. The mouth is provided with two very strongly toothed lips (fig. 5).

Habitat.-Taken in the tow-net, off Cape Howe, Australia, at night, and in lat. $36^{\circ} 32^{\prime} \mathrm{S}$., long. $132^{\circ} 52^{\prime} \mathrm{W}$. (Station 287).

In my preliminary notes and drawings of these Australian specimens, I set the species down as undescribed, relying upon the marked moniliform character of the anterior male antennæ, and the peculiar reflexed setæ of the posterior foot-jaw in the same sex. But further examination of northern specimens has showed me that both those characters, not

\footnotetext{
1 The measurements are always exclusive of the tail setæ.
} 
hitherto noticed, I believe, by any author, are equally well developed in the typical Calanus finmarchicus of the North Sea. Such examples as have usually come under my notice, taken off the east coast of England, or in other places very near to the English coast, are comparatively small, and have their salient characters not strongly marked ; but I have recently had the opportunity of examining specimens collected in more northern latitudes, during the cruise of the "Knight Errant," and I cannot see that these differ in any respect from the southern form. Thus, the only reasonable course is to consider both the northern and southern forms as belonging to one species, probably the most abundant and most widely distributed of all the Copepoda. In the arctic regions it is known to be very abundant, and the specimens described by Roussel de Vauzème from the antarctic seas are identically the same. I do not know, however, of its occurrence in the warm seas of the tropics.

Though this species has already been frequently described and figured, I have thought it best to give drawings of some of the most distinctive characters as seen in southern specimens. The figures have all been drawn by aid of the camera lucida.

\section{Calanus valgus, n. sp. (Pl. III. figs. 1-7).}

Length, 1-7th of an inch $(3.5 \mathrm{~mm}$.). Forehead broadly rounded, rostrum long and slender; head incompletely separated from the thorax (fig. 1). Anterior antenna rather longer than the cephalothorax, its setæ distributed as in Calanus finmarchicus. Posterior antennæ and mouth organs as in Calanus finmarchicus. Swimming feet very long and slender, their marginal spines longer than in the preceding species. The right fifth foot of the male (fig. 5) is not very much longer than the left, but the marginal spines of the first and second joints are very long,--longer indeed than the joints themselves; the third joint bears a comparatively short apical spine; the inner branch is destitute of setæ, but bears small marginal spines; the foot of the right side (at any rate in spirit specimens) is usually flexed at a right angle, as shown in fig. 6 ; basal joint of the peduncle finely serrated on the inner margin. All the joints of the male abdomen are nearly equal (fig. 7), but in the female (fig. 1) the first two joints are much longer than the following two.

Habitat.-Off Cape Howe, Australia, at night; in the Arafura Sea, in several South Pacific Stations $(287,288,295,296,299)$ between lat. $38^{\circ}$ S., long. $94^{\circ} \mathrm{W}$., and lat. $33^{\circ}$ $31^{\prime}$ S., long. $74^{\circ} 43^{\prime}$ W. ; in lat. $36^{\circ} 9^{\prime}$ S., long. $48^{\circ} 22^{\prime}$ W. (Station 324, South Atlantic), and in lat. $3^{\circ} 10^{\prime} \mathrm{N}$., long. $14^{\circ} 51^{\prime} \mathrm{W}$. (Station 348 , North Atlantic). The gathering from Station 296 consisted entirely of this species, and in several others it was also tolerably abundant.

\footnotetext{
1 Exploration of the Faröe Channel during the summer of 1880, in Her Majesty's hired ship "Knight Errant," Staff-Commander Tizard and John Murray, Proc. Roy. Soc. Edin., vol. xi. pp. 638, et seq. 1882.

(ZOOL. CHALL. EXP.-PART XXIII. - 1883.) 
3. Calanus propinquus, n. sp. (Pl. II. figs. 1-7, and Pl. XIV. figs. 10, 11).

Length, 22-100ths of an ineh $(5.5 \mathrm{~mm}$.). Head indistinctly separated from the thorax; forehead broad and obtuse, thorax narrowed towards the posterior extremity, and terminating in acute lateral angles. Caudal stylets oblong, divergent, about twiee as long as broad; setæ densely plumose, about as long as the abdomen, exeept the seeond, which is about three times as long. Anterior antennæ very little longer than body, and (in spirit speeimens) often eurled round the baek; the penultimate and antepenultimate joints have each an extremely long ringed and plumose seta. Branehes of the posterior antennæ of equal size. The basal joint of the pedunele of the fifth pair of feet bears a row of several (about fifteen) serratures on its inner margin, the last four or five being larger than the rest, and situated on the distal angle of the joint; ${ }^{1}$ marginal spines of the swimming feet rather small and slender, terminal spine slender, and devoid of serratures, and slightly bent at the apex; in the male the fifth foot of the right side has its outer braneh very long, the first joint as long as the whole of the inner braneh, the seeond joint still longer, the third small, subovate, and bearing a slender terminal spine; spines of the outer margin of the limb obsolete, the inner branehes of both sides are destitute of setæ. The basal serratures in the male are of uniform size.

Habitat.-I have noticed this speeies in the following gatherings :-Lat. $46^{\circ} 46^{\prime} \mathrm{S}$., long. $45^{\circ} 31^{\prime}$ E. (Station 146); lat. $64^{\circ} 37^{\prime}$ S., long. $85^{\circ} 49^{\prime}$.E. (Station 154); and in lat. $47^{\circ} 25^{\prime}$ S., long. $130^{\circ} 12^{\prime}$ E.; and between Stations 298 and 299 (South Paeifie); in lat. $35^{\circ} 41^{\prime} \mathrm{N}$., long. $157^{\circ} 42^{\prime}$ E. (Station 241) ; lat. $40^{\circ} 3^{\prime}$ S., long. $132^{\circ} 58^{\prime} \mathrm{W}$. (Station 288); and in lat. $9^{\circ} 43^{\prime} \mathrm{S}$., long. $13^{\circ} 51^{\prime} \mathrm{W}$. (Station 342); in lat. $3^{\circ} 10^{\prime} \mathrm{N}$., long $14^{\circ} 51^{\prime} \mathrm{W}$. (Station 348); off Kerguelen Island; and in lat. $37^{\circ} 17^{\prime} \mathrm{S}$., long $53^{\circ} 52^{\prime} \mathrm{W}$. (Station 320).

\section{Calanus tonsus, n. sp. (Pl. IV. figs. 8, 9).}

Female.-Length, 1-7th of an ineh $(3 \cdot 6 \mathrm{~mm}$.). Like Calanus finmarchicus and Calanus propinquus, exeept that the anterior antennæ (fig. 8) are almost entirely devoid of setæ except on the three apieal joints, those of all the other joints being almost impereeptible; the posterior antennæ are setiform along almost the whole length, like those of Calanus propinquus. The fifth pair of feet have no basal serratures, and the first segment of the female abdomen is large and tumid (fig. 9). The anterior antennæ are as long as the body of the animal. No males were seen.

Habitat.-Taken abundantly in the tow net in lat. $38^{\circ} 6^{\prime} \mathrm{S}$., long. $88^{\circ} 2^{\prime} \mathrm{W}$. (Station 296), and in another gathering from the same latitude, but about 4 degrees further west; also in lat. $35^{\circ} 41^{\prime} \mathrm{N}$., long. $157^{\circ} 42^{\prime}$ E. (Station 241) ; about lat. $40^{\circ}$ S., long. $132^{\circ} \mathrm{W}$. (near Station 288); in lat. $39^{\circ} 22^{\prime} \mathrm{S}$., long. $98^{\circ} 46^{\prime} \mathrm{W}$. (Station 294); in lat.

1 The figure of the entire foot in Pl. II. has been drawn from a limb placed in a distorted position, and gives an ncorrect idea of the arrangement of the spines. 
$36^{\circ} 9^{\prime}$ S., long. $48^{\circ} 22^{\prime}$ W. (Station 324); lat. $36^{\circ} 44^{\prime}$ S., long. $46^{\circ} 16^{\prime} \mathrm{W}$, at a depth of 650 fathoms, from the dredge (Station 325).

Although this species is certainly very nearly allied both to Calanus finmarchicus and Calanus propinquus, I am unable, on account of the differences noted above, to refer it to either of them. It does not seem likely that these differences depend upon immaturity, seeing that the specimens appear to be of full size, and are perfect as to the number of joints in the swimming feet, where, if at all, we ought to find signs of imperfect development. Besides the two species here mentioned, Calanus tonsus might not unreasonably be referred to several of Dana's species, notably to rotundatus, comptus, nudus or magellanicus. But in all these cases certain descriptive details given by Dana throw doubt upon the propriety of such identification. Some of the points of divergence are these:-In rotundatus the antennal setæ are stated to be "short, those near the base scarcely longer than the diameter;" in comptus the antennæ are " a little longer than the cephalothorax;" in nudus the "abdomen is apparently three-jointed, yet the first articulation is somewhat uncertain, antennæ scarcely longer than the cephalothorax;" and in magellanicus there are only "four pairs of natatories, the fifth rudimentary."

5. Calanus gracilis, Dana (Pl. V. figs. 1-6; and Pl. XLVI. fig. 1).

Calanus gracilis, Dana, Crust. U. S. Expl. Exped., p. 1078, pl. lxxiv. fig. 10.

Length, 1-7th of an inch $(3.6 \mathrm{~mm}$.). Anterior antennæ about once and a-half the length of the body, slender, sparingly clothed with very short setæ, except the penultimate and antepenultimate joints, each of which bears an excessively long, ringed, and densely plumose seta. The outer branches of the third and fourth pairs of swimming feet in the male have the margin of the last joint, between the base and the median spine, strongly serrated (Pl. V. fig. 5); in the female the same space is finely ciliated (fig. 4); the terminal spines of the feet are simply sword-shaped, the serrations of the edge scarcely perceptible: in the first foot, however, there is, as usual, no spine, but the outermost seta of the external branch (Pl. V. fig. 3, and Pl. XLVI. fig. 1) is widened near the base, where it forms a harpoon-like process, and the first joint is produced quite at the base into two short, stout, divaricate spines, and has also a curious appendage, in shape somewhat like the letter $f$, slightly prominent, about half the length of the limb, and laid lengthwise along its basal half. This is plainly seen without any dissection, and is quite diagnostic of the species. The fifth foot of the female does not differ from the rest, but on the right side in the male (fig. 6) is of abnormal form, while that of the left side is normal. The abdomen is short, scarcely one-third the length of the cephalothorax, caudal stylets about as long as broad, setæ short and subequal, except the second, which is nearly as long as the whole body of the animal. All the setæ of the swimming feet are distinctly jointed in the middle. 
Habitat.-This species occurred in moderate numbers in surface-net gatherings from many different localities :- "Lat. $26^{\circ} 21^{\prime}$ N., long. $33^{\circ} 37^{\prime} \mathrm{W}$., down to 80 fathoms, May 3 , 1876 ;" and near the Philippine Islands, January 1875 ; also between Api and Cape York; off Port Jackson, at night ; off Kandavu, Fiji ; in lat. $9^{\circ} 43^{\prime}$ S., long. $13^{\circ} 51^{\prime} \mathrm{W}$. (Station 342 ); and in several North Atlantic gatherings betwcen lat. $3^{\circ} 10^{\prime}$ N., long. $14^{\circ} 51^{\prime} \mathrm{W}$., and lat. $9^{\circ} 9^{\prime} \mathrm{N}$., long. $16^{\circ} 41^{\prime} \mathrm{W}$. (Stations 348-351). I cannot be quite certain that this is rightly assigned to Dana's Calanus gracilis, though his description and figures contain nothing inconsistent with that supposition. Even if this be the case, it is more than probable that future research will render necessary the formation of a new genus for the reception of this and other allied forms. At present I have seen only one male specimen, and am unable to spcak with confidence as to the structure of the fifth feet, which were not very distinctly made out. But I can scarcely doubt that they are distinct from those of the typical Calani.

6. Calanus princeps, n. sp. (Pl. IV. figs. 3-7).

Female.-Length, half an inch (12.5 mm.). Anterior antennæ (fig. 4) longer than the body, slender, sparingly sctiferous, the basal joints, as far as the eighth, very short, the rest very long,-mostly four or five times as long as broad,- - except the twenty-fourth, which is short, and bears on the middle of its inner margin an excessively long plumose seta. the branches of the mandible-palp are very short, equal, the outer having two, the inner three joints. The maxilla-palp (fig. 5) is made up of fewer segments than usual, having one quadrate and two ovate plates, together with a single, small bisetose digit. The anterior foot-jaws are armed with strong, curved setæ, which are densely clothed on their inner margins with short, delicate, and closely set hairs (fig. 6), except towards the base, where the setæ are naked. The joints of the outer branches of the swimming feet (fig. 7) are much constricted at the base, the marginal spines are short and stout, the terminal spincs very slender, with finely serrated margin. The setæ, both of feet and mouthorgans, are all densely feathered with long, brownish cilia. The colour of the body is a deep reddish-brown. The abdomen is short, stout, and three-jointed. ${ }^{1}$

Habitat.-This fine species-the largest, so far as I know, of the Calanidæ-occurred in two dredgings, but only one specimen was found in each locality. Station 45, lat. $38^{\circ} 34^{\prime} \mathrm{N}$, long. $72^{\circ} 10^{\prime} \mathrm{W}$.; depth, 1240 fathoms ; bottom temperature, $2^{\circ} 4^{\prime} \mathrm{C}$. ; mud.-Station 50 , lat. $42^{\circ} 8^{\prime}$ N., long. $63^{\circ} 39^{\prime} \mathrm{W}$. ; depth, 1250 fathoms; bottom temperature, $2^{\circ} 8^{\prime} \mathrm{C}$. ; grey ooze.

1 Since this description was written, Mr. Murray has sent me a drawing made by Dr. von Willemöes-Suhm from a freshly taken specimen. A memorandum on the drawing states that the animal was found "on the swabs of the dredge (surface ?) on May 3, 1873, depth 1250 fathoms, off Sandy Hook, North America, lat. $38^{\circ} 34^{\prime}$ N., long. $72^{\circ} 10^{\prime}$ W." I am disposed to think, seeing that all the specimens have been obtained from the dredge, that this species is really an inhabitant of the deep sea, and not casually entangled by the dredge on its way to the surface. 
I refer these specimens, only provisionally, to the genus Calanus, from which they differ in some important particulars,-in the structure of the maxilla-palp, and in the presence of only three segments in the female abdomen. But as the male is unknown, and as the structure of the maxillæ in allied species has scarcely as yet received sufficient attention, it seems best, for the present, to defer any attempt to frame a complete generic definition.

\section{Eucalanus, Dana.}

Eucalanus and Calanus (in part) Dana, Crust. U. S. Expl. Exped. (1852.)

Calanus, Lubbock, Trans. Entom. Soc. (1856.)

Calanella, Claus, Die frei lebend. Copep. (1863.)

Body straight, slender and elongated; anterior portion of the head much attenuated and elongated ; forehead triangular, prominent, rostrum very slender and furcate. Last four thoracic segments very small. Anterior antennæ composed of twenty-three or twenty-four joints, bearing (in the male) numerous club-shaped appendages; setæ small, except towards the apex. Inner branch of the posterior antennæ seven or eight-jointed, shorter than the outer branch. Mandible palp composed of one large and one very small two-jointed secondary branch. Anterior foot-jaws of moderate size, posterior excessively long. Four pairs of feet in the female, five in the male, the fifth pair one branched and prehensile. Eyes small, simple. Abdomen short, composed of four joints in the male, of three in the female.

The anterior portion of the body, composed of the head and first thoracic somite, is extremely long,-more than twice the length of the rest of the body (Pl. VI. fig. 1); the forehead, from which springs the rostrum, forms a triangular projection between the two rounded, somewhat bulbous sides, behind which there is a slightly constricted neck (fig. 2). The animal, though large, seems to be excessively fragile, at any rate in its antennæ and feet, the antennæ especially being often broken away so as to leave visible only a very small portion of their original length. The smaller branch of the posterior antennæ (fig. 4) is fusiform, eight-jointed, the first two joints being large, the last six small and gradually tapering towards the apex; the larger branch is two-jointed, large, and bears long terminal setæ. The mandibles (fig. 5) are broad and numerously toothed at the apex, the basal joint of the palp very large, the apical portion much smaller, and composed of four joints; to the basal joint is attached a very small two-jointed branch, which bears three apical setæ. The maxillæ (Pl. II. fig. 8) are very large, and their distal segments are more than usually elongated. The anterior foot-jaws (Pl. VI. fig. 6) have the normal form, but according to Claus, are more powerfully armed in the female than in the male, the lateral segments unusually large. The posterior foot-jaws are very large, in the female six-jointed (Pl. II. fig. 9), elongated, and not differing much from the normal form; in the male (Pl. VI. fig. 7) 
smaller and not so slender, the setæ stouter than in the female, shorter, and recurved. The four pairs of swimming feet are very short, nearly alike, the inner branches about half the length of the outer, and three-jointed, except in the first pair, where they have only two joints. The fifth pair is absent in the female, but in the male exists in the shape of two small, unequal, simple prehensile limbs (Pl. II. fig. 10). The abdomen is extremely short, scarcely more than one-sixth or one-seventh of the length of the cephalothorax. The second tail-seta, on the left side only, is much longer than the rest, and is about equal to the length of the body of the animal.

I have seen two species referable to this genus, both of which occurred in considerable numbers in several of the Challenger gatherings.

In his great work on the Crustacea of the United States Exploring Expedition, Prot. Dana remarks respecting Calanus attenuatus, that "the multiarticulate character of the smaller branch of the posterior antennæ may authorise the institution of a new genus, or sub-genus, for this and allied species, for which we propose the name Eucalanus. The above species will be Eucalanus attenuatus." And though Dana does not himself adopt that suggestion, but calls the species Calanus attenuatus, it yet seems to me that the name proposed by him, though in this hesitating way, may fairly claim precedence over the later generic term of Dr. Claus. I therefore accept Eucalconus as the proper name of the genus, which was very rightly separated by Claus from Calanus, on account not only of the general peculiarity of its external form, as shown in the peculiarly attenuated head, very long body, and stunted abdomen, but also on account of the abnormal structure of the antennæ, mandible-palp, and posterior foot-jaws, together with the absence of a fifth pair of feet in the female. These characters are certainly amply sufficient to sustain "Calanella" as a distinct generic form. And it seems pretty clear, as pointed out by Claus, that some species of "Calanus" described by Dana and Lubbock (e.g., Calanus elongatus, Dana; Calanus attenuatus, Dana; Calanus dance, Lubbock; and Calanus mirabitis, Lubbock) belong to "Calanella."

1. Eucalanus attenuatus, Dana (Pl. VI. figs. 1-8, and Pl. II. figs. 8-10).

Calanus elongatus, Dana, Crust. U. S. Expl. Exped. (1852), p. 1079, pl. lxxv. fig. 1.

Calanus attenuatus, idem, ibidem, p. 1080, pl. lxxv. fig. 2.

Calanus mirabilis, Lubbock, Trans. Entom. Soc., vol. iv. (1856), pl. v. figs. 1-6; and Trans. Linn. Soc., vol. xxiii. p. 178 , pl. xxix. fig. 1 .

Calanell, mediterranea (?), Claus, Die frei lebenden Copepoden (1863), p. 176, pl. xxviii. figs. 6-11.

Length, 1-6th of an inch $(4 \cdot 2 \mathrm{~mm}$.). Rostrum small (Pl. VI. fig. 3), divided at the apex into two long and slender, thread-like filaments. Anterior antennæ twentythree jointed, about one-third longer than the body, sparingly setiferous, but bearing numerous short club-shaped appendages; seventh joint longer than those immediately preceding or following it; the last joint armed with three or four, the penultimate and 
antepenultimate each with two long apical setæ. In the male the joints are constricted at the points of articulation. I hare altogether failed to find the beautifully plumose hairs figured by Lubbock and Dana as belonging to the apex of the anterior antennæ. Inner branch of the posterior antenna eight-jointed, the two basal joints large, last six joints very small and nearly equal. The inner branches of all the swimming feet (fig. 8) are three-jointed; the marginal spines of the outer branches small; terminal spines very slender, scarcely distinguishable from the marginal setæ, but bordered externally with a very delicate faintly pectinated lamina. The feet of the fifth.pair in the male (Pl. II. fig. 10) are three-jointed, the left limb longer than the right, each bearing a single small apical hair. In the female the posterior foot-jaws (fig. 9) have the three proximal tufts of setæ only plumose.

Habitat.-Between Api and Cape York; between Arrou and Banda; off the south of Papua; off Sibrabo Island, Philippines, and in various other gatherings from amongst the Philippine Islands; in lat. $46^{\circ} 46^{\prime} \mathrm{S}$., long. $45^{\circ} 31^{\prime}$ E. (Station 146); lat. $47^{\circ} 25^{\prime} \mathrm{S}$, long. $130^{\circ} 32^{\prime}$ E. (Station 159); off Port Jackson, at night; between Sydney and Wellington; off Kandavu, Fiji ; in the tropical Atlantic off the west coast of Africa, between lat. $3^{\circ} 10^{\prime} \mathrm{N}$., long. $14^{\circ} 51^{\circ} \mathrm{W}$. (Station 348); and lat. $7^{\circ} 33^{\prime} \mathrm{N}$., long. $15^{\circ} 16^{\prime}$ W. (Station 350); and in lat. $45^{\circ} 31^{\prime}$ S., long. $78^{\circ} 9^{\prime} \mathrm{W}$. (Station 303).

It will be seen from the foregoing list, that almost all the Challenger gatherings in which this species was noticed, are from the Malayan and Australasian Seas, the exceptions being those from the west coasts of Patagonia and Africa. Professor Dana's specimens, however, were from the Pacific (Kingsmill Islands) and China Seas; Sir John Lubbock's from the Bay of Biscay, and Dr. Claus's (which as I think are in all probability identical with the present species) from the Mediterranean. There can scarcely be a better instance of the very wide distribution of a species, which is nowhere perhaps very abundant when compared with such as Calanus finmarchicus, Anomalocera patersonii or Undina vulgaris. Further research may perhaps show differences sufficient to require specific recognition, but if so, the relationship between the various species may be expected to be very close indeed, showing not greater divergence than might be the result of prolonged exposure to somewhat different external conditions. The anterior antennæ (Pl. VI. fig. 1) are inaccurately drawn, showing too large a number of joints. When the figure was drawn I had not seen a specimen with perfect antennæ, and the drawing was made up from observations of several animals : the number of joints ought to be twenty-three.

2. Eucalanus setiger, n. sp. (Pl. III. figs. 8-15).

Length, 1-7th of an inch $(3.5 \mathrm{~mm}$.). Forehead broadly rounded, with little or no constriction behind, rostrum with a long, stout base and slender bifid apex; head not at 
all attenuated, distinctly separated from the thorax, and constricted at the point of junction. Anterior antennæ somewhat longer than the body of the animal, twenty-four jointed, clothed with very short setæ, two or three on each joint, and with a single, rather longer, rigid seta at the apex of the second, third, eighth, thirteenth, fifteenth, and seventeenth joints; the last two joints bear a lash of setæ of moderate length; in the male the antennal joints are constricted at the bases. Posterior antennæ slightly different in the two sexes, as .in Eucalanus attenuatus (figs. 9, 10). Basal joint of the mandible-palp (fig. 11) short and broad, outer branch composed of only one joint, inner branch small and two-jointed. Maxillæ and foot-jaws asin Eucalanus attenuatus. The swimming feet (fig. 12) have no terminal spines; all the inner branches are two-jointed, except those of the first pair, which are one-jointed (?). Those of the fifth pair of the male are very slender (fig. 13), simple, and composed of five joints, the last of which is small and setiform. The last two thoracic segments bear each a slender, divaricate lateral seta (fig. 14). The abdomen of the female is extremely short and three-jointed, that of the male (fig. 15) four-jointed.

Habitat.-Between Sydney and Wellington; Arafura Sea; off Sibrabo Island and Zebu Harbour, and at two other stations (circa 201, 202) amongst the Philippine Islands; off St. Vincent Islands, Cape Verde; in lat. $7^{\circ} 33^{\prime} \mathrm{N}$., long. $15^{\circ} 16^{\prime} \mathrm{W}$. (Station 350); and in lat. $34^{\circ} 37^{\prime}$ N., long. $140^{\circ} 32^{\prime}$ E. (east of Japan, Station 237).

In general appearance this is deceptively like the male Calanus finmarchicus, and affords a remarkable instance of homomorphism-perhaps even of mimetic resemblancebetween two certainly distinct genera. I do not remember to have seen amongst the Calanidæ any other so well marked example of this condition. Without minute examination, the only palpably distinctive character is the somewhat greater length of the antennæ of Eucalanus. The two genera, however, differ essentially in the structure of the posterior antennæ and the fifth pair of feet.

\section{Rhincalanus, Dana.}

Animal slender and elongated, cephalothorax many times as long as the abdomen; head and thorax coalescent, five-jointed; anterior part of the head produced. Anterior antennæ alike in both sexes, much longer than the body, bearing numerous short and a few very long setæ; inner branch of the posterior antennæ multiarticulate, the last five joints very short and nearly equal. Mandibles broad and strongly toothed at the apex; palp well developed, with a large basal joint and two branches, one composed of two, the other of three joints. Maxillæ and foot-jaws nearly as in Calanus. Swimming feet, five pairs, short; inner branches of the first four pairs small and three-jointed, except in the first pair, which has only two joints; fifth pair one or two-branched. Abdomen fourjointed. 
Dana separated this form from its relatives, and gave it generic rank, simply on the strength of its strongly produced rostrum, a character certainly insufficient of itself to maintain the generic distinction. But as the fifth pair of feet (at any rate in Rhincalanus gigas) presents some differences of structure, I have retained, provisionally, Prof. Dana's name, though with much doubt as to the propriety of doing so.

\section{Rhincalanus cornutus, Dana (Pl. VII. figs. 1-10).}

Rhincalanus cornutus, Dana, Crust. U.S. Expl. Exped., p. 1083, pl. lxxvii. fig. 2, a.d.

Female.-Length, 1-7th of an inch $(3.5 \mathrm{~mm}$.). Forehead very much produced, attenuated, terminated by a triangular, slenderly furcate rostrum, between which and the anterior part of the head, as seen laterally, is a deep sinus; cephalothorax four or five times as long as the abdomen, and very slender; the posterior margins of all except the first and last segments produced at each side into a sharp, backward-pointing spine. Anterior antennæ about one-fourth longer than the body, twenty-three-jointed, the basal joint very long, one very long marginal seta near the base, one on the twelfth, fourteenth, sixteenth, nineteenth, and twenty-first joints, two on the twenty-second, and a lash of four or five at the apex of the last joint. Posterior foot-jaws (fig. 7) of no great length, and in structure like those of Calanus; peduncle two-, flagellum five-jointed. Inner branches of the first pair of swimming feet two-jointed (fig. 8), second joint of the peduncle swollen at the inner side, and bearing a setose tuft; outer branch bearing three ciliated spines. The second, third, and fourth swimming feet have their inner branches three-jointed, the outer branches destitute of marginal spines (fig. 9), except the first joint, the outer margin of which is swollen and produced into an apical tooth; the terminal spines of the swimming feet are long, very slender, and have an extremely delicate hyaline lamina extended along the outer margin, but are in no other respect distinguishable from the neighbouring setæ. Fifth pair of feet (fig. 10) simple, three-jointed, short, the last joint bearing two apical spines of unequal length, the larger of which is marginally ciliated. Abdomen four-jointed (three-jointed, Dana), first segment about as long as the following three, and spined at its postero-dorsal angle. Caudal laminæ about twice as long as broad, setæ about as long as the abdomen, except the second on the left side, which is twice as long as the rest.

That the specimens above described are females, I conclude, from the fact of spermatophores having been seen attached to the abdomen of some of them. Amongst all the specimens I have not been able to find any difference which appeared to me to be sexual, except that in one or two no fifth pair of feet was discernible. I think, however, that these examples were probably immature. It will be noticed that the number of segments

(ZOOL. CHALL. EXP.-PART XXIII.-1883.) 
figured in the cephalothorax and abdomen differs in the two specimens represented in the plate (figs. 1 and 2). These were drawn as they appeared under the microscope. The differences may perhaps be sexual, but of this I could find no evidence.

Habitat.-Off Sibrabo Island, and in several other localities amongst the Philippine Islands; and in lat. $5^{\circ} 28^{\prime} \mathrm{N}$., long. $14^{\circ} 38^{\prime} \mathrm{W}$. (Station 349). Dana's specimens were collected in the Sulu Archipelago.

2. Rhincalanus gigas, n. sp. (Pl. VIII. figs. 1-11).

Female.--Length of the body one-third to three-eighths of an inch (8.5-10 mm.). Anterior antennæ twenty-three-jointed, nearly as in Rhincalanus cornutus, but with somewhat shorter marginal setæ. Forehead not so much elongated as that of Rhincalanus cornutus. Ventral angles of the last three thoracic segments produced into overlapping spines. Abdomen composed of four segments, the first and last of which form spinous processes at their postero-dorsal angles. The inner branches of the swimming feet are three-jointed, the outer branches very feebly spinous, the spines, as in Rhincalanus cornutus, being merely small, unjointed processes of the limb, in the last joint amounting to little more than marginal crenulations (fig. 8). The feet of the fifth pair (figs. 9, 10) are one or two (?) branched, the terminal joint bearing three, the penultimate joint one apical seta. Caudal stylets about as long as broad, setæ subequal (fig. 11).

Habitat.-Rhincalanus gigas, though distributed over a very wide area, seems to be much more abundant in the southern hemisphere than in more northern latitudes. The following list indicates the localities in which it was taken by the surface-net during the cruise of the Challenger:--In lat. $65^{\circ} 42^{\prime}$ S., long. $79^{\circ} 49^{\prime}$ E., 80 fathoms (Station 153); lat. $64^{\circ} 37^{\prime}$ S., long. $85^{\circ} 49^{\prime}$ E. (Station 154 ) ; lat. $47^{\circ} 25^{\prime}$ S., long. $130^{\circ} 32^{\prime} \mathrm{E}$. (Station 159); near Station 206, January 9, 1875 ; lat. $37^{\circ} 17^{\prime}$ S., long. $53^{\circ} 52^{\prime} \mathrm{W}$. (Station 320) ; lat. $36^{\circ} 44^{\prime}$ S., long. $46^{\circ} 16^{\prime}$ W. (Station 325); and between Japan and Honolulu.

This species differs from Rhincalanus cornutus chiefly in size, being more than twice as long; also in the less attenuated forehead, in the situation of the thoracic spines (which are on the ventral surfaces of the somites instead of on the dorsal), and in the characters of the fifth pair of feet. Fig. 9 in the plate represents, I believe, the normal form of that limb, but in another specimen it was found as in fig. 10. No perfect anterior antennæ were seen, but those shown in the figure are probably nearly, if not quite, correct. The terminal spines of the swimming feet are very slender and scarcely distinguishable from the marginal setæ. The specimens here described are probably females, in which case the male has yet to be discovered. 


\section{Hemicalanus, Claus.}

Hemicalanus, Clans, Die frei lebenden Copepoden, 1863 (not Hemicalanus of Dana).

Body pellucid, somewhat depressed, eyes entirely wanting (?). Anterior antennæ twenty-five jointed, that of the left side in the male slightly geniculated. Posterior antennæ elongated, secondary branch five or six-jointed, the median joints minute and sometimes not distinctly separate. Mandibles almost styliform, two-toothed. Anterior pair of foot-jaws elongated, posterior still longer, robust. Fifth pair of feet two-branched, those of the female like the preceding pairs, as also those of the male, ${ }^{1}$ except that the outer branch is uncinate. Abdomen short, composed in the male of five, in the female of four segments.

Of this remarkable genus I have seen but few examples, most of which were very imperfect. The foregoing definition is therefore copied almost verbatim from Dr. Claus, though in some points it does not quite agree with my own observation, to which, however, I cannot in this case allow much weight. In the best of the Challenger specimens (figured in Pl. IX. fig. 1) there were two small closely-approximated spots on the front of the head, which I took to be eyes, and I was unable, except in one specimen, to make out more than two joints in the secondary branch of the posterior antenna. The joints of the anterior antennæ were also very indistinctly visible, and those organs, as shown in fig. 1, are evidently imperfect.

The genus as originally constituted by Dana contains species probably belonging to two or more genera, and is certainly in that form untenable. It is impossible, indeed, from the insufficiency of the published characters, to say with certainty where the species assigned to it should properly be placed. None of them can be referred to Hemicalanus as understood by Claus, and upon which he makes the following remarks : ${ }^{2}$ - "This genus, of which five species are known to me-on account of its delicate structure, the transparency of its body, and its several peculiarities of organisation-ranks amongst the most beautiful and interesting of all the Calanidæ. The entire body is extremely slender, like that of Calanella (Eucalanus), but broader and flatter; the abdomen is smaller and more slender but completely segmented, composed in the female of four, or rarely three, and in the male of five segments ; the last segment, bearing the furca, is broad, and often produced, fan-like at the sides. In the species known to me, the cephalothorax is composed of four segments only, the head and first thoracic, as well as the two hindmost segments of the body, being coalescent. . . . The male antenna is hinged between the nineteenth and twentieth joints, but there is no marked swelling of the foregoing joints. The posterior antennæ are largely developed, the main branch of great length, and

1 I cannot reconcile this statement of Dr. Claus with my observation of the fifth pair of feet in the Challenger specimen, which were as represented in fig. 1.

${ }^{2}$ Die frei lebenden Copepoden, p. 177. The translation here given is an abstract only of the more important parts. 
bearing long, plumose apical setæ; the secondary branch usually much shorter, and shewing an elongated basal joint, with four incompletely separated median joints. Not less interesting is the form of the mandibles, the biting part of which is very slender, almost stylet-shaped, and terminates in two long, sharp teeth; the palp consists of an elongated peduncle, with two well-developed branches. . . . The maxillæ, instead of having as in Calanus a short lappet-like appendage, show an elongated rod-like process, bearing at its apex two excessively long and usually plumose setr. . . . The fifth pair of feet of the male differ from those of the female in the conversion of the extremity into a prehensile organ; the outer branch of both feet is destitute of setæ, but has at the apex a claw, and the foot of the right side differs still further in having its penultimate joint excavated on the inner border, while the last joint has its marginal spine much enlarged and turned inwards."

That Claus should have found five species of Hemicalanus in the Mediterranean seems very remarkable, inasmuch as three forms only were noticed in the Challenger gatherings which passed through my hands, and they were represented only by about half-a-dozen specimens in all.

\section{Hemicalamus longicornis, Claus (Pl. IX. figs. 1-7).}

Hemicalanus longicornis, Claus, Die frei lebenden Copepoden, p. 179, pl. xxix. fig. 1.

Length, 1-10th of an inch $(2.5 \mathrm{~mm}$.). Forehead short and broad, subtriangular; anterior antennæ twice as long as the body, very slender beyond the middle, plentifully provided with very long setæ (fig. 1). Posterior antennæ (fig. 2) very long and slender, secondary branch very small, six-jointed, reaching to the end of the second joint of the larger branch; the small intercalated joints very indistinct, four or five in number. The five pairs of swimming feet all nearly alike; inner branches only about one-half as long as the outer. Abdomen short, about one-fifth of the length of the body; caudal stylets twice or thrice as long as broad; setæe five, nearly equal, not longer than the abdomen. Branches of the mandible-palp (fig. 3) slender, the outer branch two-, the inner one-jointed.

Habitat.-South Pacific, lat. $40^{\circ} 3^{\prime}$ S., long. $132^{\circ} 58^{\prime}$ W. (Station 288), and North Atlantic in lat. $26^{\circ} 21^{\prime} \mathrm{N}$., long. $33^{\circ} 37^{\prime} \mathrm{W}$., taken in the tow-net down to 80 fathoms (Station 353). The last-named locality, it will be seen, is almost in the same latitude, and may be supposed to afford pretty much the same external conditions, as the Sicilian Station, at which the same species was found by Dr. Claus. The specimen figured in our plate, though imperfect, is drawn accurately from one of the two found in the above-mentioned gathering. ${ }^{1}$

1 Except as to the jointing of the posterior antennæ, which was taken from a Pacific specimen. 
2. Hemicalanus orientalis, n. sp. (Pl. IX. figs. 8, 9, and Pl. X. figs. 1-4).

Anterior antennæ (Pl. X. fig. 1) as long as the body, slender, and rather densely clothed with long setæ. The rostrum is long and slender, and the swimming feet much more robust than in the preceding species. One specimen only was found. Length, 1-9th of an inch $(2.8 \mathrm{~mm}$.). Male unknown.

Habitat.-Between Arrou and Banda.

\section{Hemicalanus aculeatus, n. sp. (Pl. XLVI. figs. 2-4).}

Length, 23-100ths of an inch $(5.75 \mathrm{~mm}$.). Forehead produced and sharply aculeated, body subcylindrical, cephalothorax six or seren times as long as the united lengths of abdomen and furca. Anterior antennæ longer than the body, twenty-five-jointed, basal joints short and clothed with plumose hairs, distal joints much more slender and bearing non-plumose setæ. Secondary branch of the posterior antenna long, six-jointed, and bearing very long plumose hairs, those of the primary branch non-plumose. Four pairs of swimming feet, which have all the branches three-jointed, the outer branches of all except the first pair bearing beautifully plumose setæ. Abdominal segments, except the first, extremely short; caudal lamellæ subquadrate, not much longer than broad and slightly divergent; setæ five, the outer about half as long as the inner, all densely plumose, the longest about twice the length of the abdomen. The proximal halves of the setæ throughout the body are usually either destitute of plumes or have them only slightly developed; colour of the plumes smoky brown.

I have seen only one specimen of Hemicalanus aculeatus, which was mounted during the cruise and labelled "Deep haul, 23rd July 1875, Pacific." The drawing of the whole animal given in Pl. XLVI. was taken from the mounting, and shows all that I could make out of the details before dissection.

\section{Pleuromma, Claus.}

Pleuromma, Claus, Die frei lebenden Copepoden, 1863.

Metridia, Boeck, Oversigt af Norges Marine Copepoder (1864).

, Brady, Monog. British Copepoda, 1878.

Head distinct from the thorax; fourth and fifth segments of the thorax coalescent; abdomen composed in the male of five, in the female of three segments. Anterior antennæ twenty-five-jointed in the female, that of the left side in the male twentythree-jointed, ${ }^{1}$ that of the right side nineteen-jointed and geniculated between the

\footnotetext{
1 In some cases the eighth and ninth articulations of the left antennæ are distinctly marked, and this condition is shown in the plate.
} 
fifteenth and sixteenth joints; posterior antennæ and mouth-organs as in Calanus. First pair of feet much smaller than the rest; both branches of the first four pairs threejointed; fifth pair composed of one branch only, prehensile in the male. A black, spherical eye spot, covered with a highly refracting lens, is situated on the side of the body, near the base of one of the foot-jaws.

Amongst other characters of his genus Pleuromma, Dr. Claus states that the head and thorax are coalescent, and that the inner branch of the first pair of swimming feet is composed of only two joints. Boeck, therefore, relying upon the distinctly separated head and thorax, upon the three-jointed inner branch of the first foot, and upon the absence of a pleural eye, necessarily assigned his new species Metridia armata to a distinet genus. But, while hesitating to disagree with so accurate an observer as Dr. Claus, I am bound to say that I believe his definition of Pleuromma to be founded-so far as regards the fusion of the head and thorax, and the jointing of the first pair of feet-on mistaken observation, or, it may be, on data derived from immature specimens. On the other hand, specimens of Pleuromma may frequently be found in which no lateral eye is visible (at any rate in spirit specimens), while the inconstant position of this organ, sometimes on the right side and sometimes on the left, seems to sanction the supposition that it is to some extent an extraneous appendage. I therefore think, taking one consideration with another, that there is no sufficient reason to maintain the separation of the two genera, and though doubtless Pleuromma is a misnomer when applied to species having no pleural eye ${ }^{1}$, it.must be adopted on the ground of priority.

Pleuromma abdominale, Claus (Pl. XI. figs. 1-13, and Pl. XII. figs. 1-16, and Pl. XXXI. figs. 13, 14).

Pleuromma abdominale, Claus, Die frei lebenden Copepoden, p. 195, pl. v. figs. 1-6, 13, 14, pl. vi. figs. 1-10.

Diaptomus abdominalis, Lubbock, Trans. Entom. Soc., vol. iv. (1856), p. 22, pl. x. figs. 1-8.

(?) Pleuromma gracile, Claus, Die frei lebenden Copepoden, p. 197, pl. v. figs. 7-11.

Length, 1-8th of an inch (3 mm.). Cephalothorax elongated, moderately robust; anterior antennæ twenty-five-jointed, about as long as the body, towards the base densely clothed with rather short setæ, interspersed with others of moderate length; the second and third joints in the female each armed with a sharp, recurved marginal spine, the following six or eight joints doubly denticulated (Pl. XI. fig. 2). The right anterior antenna of the male (fig. 4) has a strongly denticulated plate (fig. 5) on the proximal side of the hinge-joint, the sixth joint is imperfectly divided into three, and the tenth, eleventh, and fourteenth, are angularly dilated at the apices. The inner branch of the second pair of feet, on the left side only in the male (fig. 6), but on both sides in the female, has

\footnotetext{
1 In the northern species, Metridia (Pleuromma) armata, there is no pleural eye.
} 
its first joint deeply excavated at the base, the lower border of the sinus forming at its outer angle a strong curved spine. The outer branch of the third pair of feet in both sexes has the basal joint produced extemally into a stout thumb-like prominence (fig. 7), and the two following joints have deeply sinuated margins, bordered with chitinous plates. The fifth pair of feet in the male (fig. 8) is strongly prehensile, each branch ending in a broad, clumsy, claw-like joint. In the female (fig. 10) each limb is simple, three-jointed, the last joint bearing three long, subequal apical setæ. The first segment of the female abdomen (fig. 1) is tumid, and equal in length to the two following segments; in the male (fig. 13) the abdominal somites are all of nearly equal length and shorter than broad, the last somite in both sexes dilated at the distal extremity and forming two angular lateral processes. The caudal laminæ are about twice as long as broad, the setæ subequal and rather shorter than the abdomen. In some adult males (fig. 12), the abdomen is distorted, bearing beard-like bunches of hairs or fimbriated marginal processes: in these specimens the caudal laminæ are also twisted and strongly setiferous. The pleural eye consists of a strongly pigmented ring, covered by a highly refracting lens, the whole appearing to be loosely attached just beneath the integument, and situated near the base of one of the foot-jaws. The vulva forms a prominent black, conical papilla on the front of the first abdominal somite.

The description given above applies to specimens which I believe to represent the completely developed adult form of the species:- these are figured in Pl. XI. A less fully developed form, which appears to me to belong to the same species, and which is undoubtedly identical with Pleuromma gracile, Claus, is shown in Pl. XII. and Pl. XXXI. figs. 13, 14. The chief points of difference are to be found in the length of the abdominal somites (figs. 14, 15), in the double hook of the first pair of feet (fig. 8), in the absence of the two hooked spines of the female antenna (Pl. XXXI. fig. 13), and in the want of a denticulated plate in the male antenna; the fifth pair of feet in the male (Pl. XII. figs. 10, 11) are of somewhat different shape, and in the female (fig. 12) have only two, instead of three, joints. In a still earlier stage of development (fig. 13), the branches of the female fifth foot end in three straight spines, like the prongs of a fork. A similar condition is shown in Pl. XI. fig. 11, drawn from specimens taken along with the adult form figured in the same plate. Fig. 9 in Pl. XI. represents what I believe to be an immature form of the fifth foot of the male. In some males of the immature form the antennæ bear numerous very largely developed sensory organs, club-shaped or pyriform (Pl. XII. fig. 2). These are sometimes so numerous and so closely packed that I at first doubted whether they were not parasitic growths; this, however, is certainly not the case. But the most important distinction between the normal form of the species and the Pleuromma gracile of Claus is that, in the former the right male antenna is the geniculated one, in gracile the left. This is a difference which I cannot yet satisfactorily explain. But considering the variable situation of the pleural eye, and the very fluctuating characters 
of the species in some other respects; considering also that I have met with no gathering of the adult form in which the gracile form does not also occur, and that Dr. Claus likewise found both forms in the Mediterranean,-I yet adhere to the belief that a thorough study of the development and morphology of the animal will show these two debateable forms to be but varieties of one and the same species. It is perhaps worth noting that the only females which I have seen with attached spermatophores occurred in one or two gatherings containing males which had the distorted abdomen.

Habitat.-Lat. $47^{\circ} 25^{\prime}$ S., long. $130^{\circ} 12^{\prime}$ E. ; off Port Jackson ; off Cape Howe, Australia ; off Kandavu, Fiji ; off the Ki Islands ; between Api and Cape York; Pacific, north of the Sandwich Islands; South Pacific, lat. $40^{\circ} 3^{\prime} \mathrm{S}$., long. $132^{\circ} 58^{\prime} \mathrm{W}$.; and off the west of Patagonia; lat. $36^{\circ} 44^{\prime}$ S., long. $46^{\circ} 16^{\prime} \mathrm{W}$.; lat. $37^{\circ} 45^{\prime} \mathrm{S}$. , long. $33^{\circ} 0^{\prime} \mathrm{W}$.; Atlantic from lat. $5^{\circ} \mathrm{N}$. to $2^{\circ} \mathrm{N}$.; and about lat. $26^{\circ} \mathrm{N}$, near Station 353 ; in lat. $36^{\circ}$ $32^{\prime}$ S., long. $132^{\circ} 52^{\prime}$ W. (Station 287) ; in lat. $64^{\circ} 37^{\prime}$ S., long. $85^{\circ} 49^{\prime}$ E. (Station 154); in lat. $37^{\circ} 17^{\prime} \mathrm{S}$., long. $53^{\circ} 52^{\prime} \mathrm{W}$. (Station 320 ).

\section{Heterochceta, Claus. \\ Heterochota, Claus, Die frei lebenden Copepoden, 1863.}

Body attenuated behind, abdomen of the male five-, of the female four-jointed. Anterior antennæ twenty-five-jointed; that of the left side in the male feebly geniculated. Colouring matter of the eye entirely wanting. Posterior antennæ as in Calanus. Anterior branch of the maxilla obsolete. Anterior pair of foot-jaws very stout, armed with strong curved and partly pectinated setæ; posterior foot-jaws slender, nearly as in Calanus. Fifth pair of feet two-branched, those of the female like the preceding pairs, except that the outer branch bears a very long divaricate spine at the apex of its second joint; in the male the outer branches are prehensile and slightly different on the two sides. The left caudal stylet bears one excessively long seta.

Heterochata, though abundantly distinct from any other described genus, presents some interesting points of resemblance, especially to Candace, Leuckartio and Pleuromma:-to Candace in the powerfully formed posterior foot-jaw, to Leuckartia and Pleuromma in the general build of the swimming feet and of the anterior antennæ. But the remarkably long seta of the left caudal segment, the absence of the internal branch of the maxilla, the characters of the fifth pair of feet in both sexes (which come nearer to Centropages than to any other genus), together with the very slightly deformed left anterior antenna of the male, constitute a sufficiently distinctive series of generic characters. 


\section{Heterochceta spinifrons, Claus (Pl. XIII. figs. 1-13).}

Heterochceta spinifrons, Claus, Die frei lebenden Copepoden, p. 182, pl. xxxii. figs. 8, 9, 14, 16.

Length, one-sixth of an inch $(4.2 \mathrm{~mm}$.). Cephalothorax slender, tapering to each extremity (fig. 1), rostrum short, stout and bluntly pointed, not furcate. Anterior antennæ (figs. 1,2) about as long as the body, slender; the base (in spirit specimens) thrown boldly forward from the front of the head, and then taking a sudden bend backwards; sparingly provided with very short marginal setæ, except near the base, where they are longer and more thickly set; apical joint rather short, its terminal setæ $^{1}$ not much longer than those of the other joints; in the male (fig. 3) the hinge joint forms a scarcely perceptible indentation, and there are no marginal spines or serratures. The inner branch of the posterior antenna (fig. 4) has four (? three) small median joints, and is nearly equal in size to the outer branch. The mandible (fig. 5) has four curved apical teeth, the two central teeth bi- or tri-furcate, the outermost tooth is, as it were, soldered to the side of the basal plate, its base forming a rectangular projection, and between it and the other teeth there is a wide gap. The maxilla (fig. 6) is long and slender, digitiform, has five or six stout apical setæ, a quadrate basal plate, which is marginally setose, and only one short tri-setose branch. The marginal setæ of the anterior foot-jaws (fig. 7) are very strong, and the last two are closely pectinated with short fine setæ on their inner margins; at the apex of the limb is a tuft of about six slender setæ, about half as long as the larger claws. The posterior foot-jaws (fig. 8) are like those of Calanus, but the basal joint bears one short spine, and an excessively long and strong flexuous seta. All the branches of the swimming feet, both external and internal, are three-jointed, the marginal spines are short, sharp and slender; the outer branch of the third pair (fig. 9) is, however, much dilated, and has a series of very short claw-like terminal spines. The fifth pair in the male (fig. 10) are only slightly different on the two sides; the inner branches are two-jointed, ending in a brush of six stout plumose setæ; the outer branches end in long, slender claws, that of the right side having two large digitiform processes on the inner margins of the first and third joints; in the female the fifth pair are alike on both sides (fig. 11), and differ little from the first and second pairs, except that the median joint of each outer branch bears on its inner margin a strong divaricate and slightly curved spine, which is as long as the third joint, and in the natural position of the limb crosses its fellow of the opposite side. The first abdominal somite in the impregnated female (fig. 12) is very large and tumid, the receptaculum seminis (?) forming a large rounded prominence on its anterior aspect; in the male the abdominal joints are nearly equal in size. The caudal stylets are about

1 These setæ are scarcely long enough in the plate, and in fig. 1 the number of antennal joints is given incorrectly. The figure (10) illustrating the fifth pair of feet of the male, though representing rightly the specimen from which it was drawn, differs considerably from the same organs in other examples; probably, however, the discrepancies are characteristic of the various ages of the specimens.

(ZOOL. OHALL. EXP.—PART XXIII.-1883.) 
twice as long as broad-as long as the two preceding abdominal segments of the femaleand bear five setæ, which are shorter than the abdomen, except the fourth (counting from the outside) of the left stylet, which is about twice as long as the whole body of the animal. The spermatophores (fig. 12) are very large, and are attached singly; the contained spermatozoids (fig. 13) are also of unusual magnitude.

Habitat.-Torres Straits (Station 185); lat. $40^{\circ} 3^{\prime}$ S., long. $132^{\circ} 58^{\prime}$ W. (Station 288); lat. $36^{\circ} 44^{\prime} \mathrm{S}$., long. $46^{\circ} 16^{\prime} \mathrm{W}, 2650$ fathoms (Station 325 ); lat. $37^{\circ} 45^{\prime}$ S., long. $33^{\circ}$ $0^{\prime} \mathrm{W}$. (Station 330); lat. $7^{\circ} 33^{\prime}$ N., long. $15^{\circ} 16^{\prime} \mathrm{W}$. (Station 350); lat. $26^{\circ} 21^{\prime} \mathrm{N}$., long. $33^{\circ} 37 \mathrm{~W}^{\prime}$. (Station 353 ); lat. $46^{\circ} 46^{\prime}$ S., long. $45^{\circ} 31^{\prime}$ E. (Station 146); lat. $37^{\circ} 17^{\prime} \mathrm{S}$., long. $53^{\circ} 52^{\prime} \mathrm{W}$., 600 fathoms (Station 320 ).

Though occurring in several very widely separated localities, this species seems to be nowhere abundant, not more than three or four specimens having been detected in any one gathering. All these are, as I think, referable to the same species, but I am not quite certain that they can be identified absolutely with either of the two forms described by Dr. Claus. As to Heterochota spinifrons, that author lays especial stress upon the length of the anterior antennæ:- "die vordern Antennen beträchtlich länger als der Körper,"-whereas in our specimens the antennæ are very little, if at all, longer than the body. Again, in Heterochceta papilligera the posterior foot-jaws are stated to have only one spine:- "am Basalgliede des untern Maxillarfusses fehlt der obere Dorn,"-which is conclusive against its agreement with the Challenger specimens. On the whole, though with some doubt, it seems best to accept for the present the specific name spinifrons. None of the specimens which I have examined present the peculiarities ascribed to Heterocheta papilligera.

\section{Leuckartia, Claus.}

Leuckartia, Claus, Die frei lebenden Copepoden, 1863.

In general form like Heterochceta. Anterior antennæ serrated, twenty-five-jointed; that of the left side in the male geniculated, the five joints preceding the hinge slightly swollen. Posterior antennæ and mouth organs similar to those of Calanus. Fifth pair of feet two-branched, that of the right side having the outer branch strongly clawed. Both branches of the first four pairs of feet three-jointed. Each caudal stylet provided with one excessively long and several short setæ. Eye altogether wanting.

I cannot speak from my own knowledge as to the existence or non-existence of an eye. The passage in the foregoing definition which refers to this matter is taken from Claus.

1. (?) Leuckartia flavicornis, Claus (Pl. XV. figs. 1-9, 16).

Leuckartia flavicornis, Claus, Die frei lebenden Copepoden, p. 183, pl. xxxii. figs. 1-7.

Length, 1-4th of an inch $(6.2 \mathrm{~mm}$.). Body elongated; anterior antennæ slender, about as long as the body, moderately setiferous; those of the male plentifully provided 
with club-shaped, sensory filaments (fig. 2). The inner branches of the first four pairs of feet are very short and three-jointed (fig. 6), the terminal spines of the outer branches are of moderate breadth, sword-shaped, and very minutely serrated on the inner edge (fig. 7). The fifth pair of feet in the male (figs. 8, 9) have on both sides a stout, two-jointed stalk, the terminal branches being three-jointed in the left foot, and two-jointed in the right; the second joint of the peduncle on the left side has the inner margin produced into a large five-toothed quadrate lamina, that of the right side is also slightly produced, and bears three small hairs; the outer branch of the left foot is twice as long as the inner, and is unarmed except with one or two minute apical setæ; on the right side the two joints of the outer branch form a powerfully prehensile but blunt, clumsily shaped claw; the inner branch short, with an ovate terminal joint which bears four setæ at its apex. The first and fourth segments of the female abdomen (fig. 1) are much longer and broader than the two intermediate segments, caudal stylets long, at least four times as long as broad, each bearing a single marginal seta of moderate length, and four terminal setæ, one of which is about as long as the body of the animal. Abdomen of the male (fig. 10) five-jointed.

Habitat.-Off Port Jackson, Australia; off Kandavu, Fiji; lat. $30^{\circ} 44^{\prime}$ S., long. $44^{\circ} 17^{\prime}$ W.; North Atlantic in several stations from lat. $7^{\circ} 33^{\prime} \mathrm{N}$., long. $15^{\circ} 16^{\prime} \mathrm{W}$., to lat. $26^{\circ} 21^{\prime}$ N., long. $33^{\circ} 37^{\prime} \mathrm{W}$. (Stations $350-353$ ); in lat. $47^{\circ} 25^{\prime} \mathrm{S}$., long. $130^{\circ} 32^{\prime} \mathrm{E}$. (Station 159); and lat. $40^{\circ} 3^{\prime}$ S., long. $132^{\circ} 58^{\prime}$ W. (Station 288).

Very few specimens of Leuckartia were detected, and those mostly in imperfect preservation. On this account I have been unable to figure or describe the species as fully or minutely as I should have wished. I do not, however, find any noteworthy difference between the Challenger specimens and those described by Dr. Claus, except the size. Claus says " $1 \frac{3}{4}-2 \mathrm{~mm}$. long." The measurement of my figured specimen is over $6 \mathrm{~mm}$., and I am not aware that it was larger than the very few others which came under my notice.

\section{Leuckartia (?) scopularis, n. sp. (Pl. XIV. figs. 1-5).}

This species I know only from two or three imperfect specimens which were found amongst surface animals taken between Japan and Honolulu. The peculiar brush-like cushion of hairs attached to the inner side of the bases of the fifth pair of feet of the male, afford what appears to be a sufficient specific character (figs. 3, 4), and though the foot of the left side was imperfect in the only male specimen, that of the right side certainly does not agree with Leuckartia flavicornis. The anterior antennæ are twenty-five-jointed, and that of the left side is simply geniculated (fig. 2); the caudal stylets (fig. 5) long and unequal, the tail setæ shorter than the abdomen, and nearly equal, except that one on each side is about half as long again as the rest. The animal itself was not measured, nor 
were many of its parts so carefully observed as they ought to have been, as at the time I did not suspect that I should not be able to lay my hands on another specimen. The whole gathering, however, which is remarkably poor in Copepoda, has been hunted over without success, for further examples. The length of the anterior antenna is half an inch $(12.75 \mathrm{~mm}$.), and is probably about the same as that of the body of the animal.

\section{Undina, Dana.}

Undina, Dana, Proc. Amer. Acad. Sci., 1849 (not Undina of Claus).

Head anchylosed with the first thoracic segment. Anterior antennæ twenty-fivejointed in the female; those of the male alike on both sides, twenty-two to twenty-fourjointed, not geniculated, but distinctly angulated at the sixth or eighth joint. Both branches of the posterior antennæ equal in length, secondary branch four-jointed, the two median joints very short and indistinct. Mandible broad, numerously toothed, palp with a large quadrate base and two short bi-articulate branches, the first joint of the inner branch swollen and almost circular. Maxilla-palp well developed, the lower branch digitiform, three-jointed, the upper smaller and crescentic. Anterior and posterior footjaws as in Calanus. Five pairs of feet in both sexes, both branches three-jointed; fifth pair in the male on the right side very largely developed and prehensile, on the left small and not much different from the preceding pairs. Abdomen of the male five-, of the female four-jointed.

The angulated male antenna, the three-jointed inner branches of all the swimming feet, the absence of excessively long antennal and caudal setæ, the prehensile form of only one of the fifth feet in the male, and the presence of five pairs of feet in the female, are the characters which distinguish Undina from the very closely allied genus Euchata. From Scolecithrix it is separated by the larger number of joints in the anterior antenna, the equality of the two branches of the posterior antenna, the uniformly three-jointed inner branches of the swimming feet, and the presence of a normally formed fifth pair in the female, while Scolecithrix is still further distinguished by the peculiarity from which it takes its name-the presence of a fascicle of worm-like filaments at the apex of the posterior foot-jaw. Both the species here described have a very wide range of distribution, being found abundantly over almost the whole areas of the Pacific and Indian Oceans, and over a large part, at any rate, of the Atlantic. Undina messinensis, Claus, and Undina dance, Lubbock, present some peculiarities of structure which have led me to place them under a distinct genus (Scolecithrix), and Undina pulchra, Lubbock, seems properly to belong to Euchceta. 
1. Undina vulgaris, Dana (Pl. XV. figs. 11-15; and Pl. XVIII. fig. 6).

Undina vulgaris, Dana, Crustacea of U. S. Expl. Exped. (1852), p. 1092, pl. lxxvii. fig. 8, a-l. (?) Undina simplex, idem, ibidem, p. 1094, pl. lxxvii. fig. 9, $a-b$.

Undina inornata, idem, ibidem, p. 1095, pl. lxxvii. fig. 11, $a-d$.

Undina longipes, Lubbock, On some Entomostraca collected by Dr. Sutherland, Trans. Entom. Soc., 1856, p. 17, pl. vi. figs. 1-5.

Length, 1-8th of an inch $(3 \cdot 1 \mathrm{~mm}$.). Cephalothorax elongated, cylindrical, rounded in front; as seen from the side (Pl. XVIII. fig. 6); the posterior ventral angle is produced usually into two short divergent spines; seen from behind the angles of the cephalothorax are sub-acute and slightly produced downwards. Rostrum moderately long and furcate. Anterior antennæ (Pl. XV. figs. 11, 12) twenty-five-jointed in the female, twenty-four-jointed in the male, not much longer than the cephalothorax, fringed with short setr, with at distant intervals-notably on the second or third, eighth and seventeenth joints-one considerably longer than the rest; the last joint in the female has three or four short apical setæ, the last but one has two, and the penultimate one, long apical seta; the antenna of the male is angulated at the eighth joint. The second swimming foot in both sexes (fig. 13) has the second joint of the outer branch deeply indented at the base, and produced downwards into a strong spine, the whole external margin having thus a somewhat hatchet-shaped outline; the terminal spines of the swimming feet are slender, with finely serrated outer margin and bent tip. In the male, the fifth pair of feet (fig. 14) are dissimilar on the two sides, that of the right side excessively long, and when extended reaching beyond the extremity of the tail ; the two basal joints are long and slender, the third much shorter and giving attachment at its apex to a very long attenuated and irregularly flexed claw, and to an irregularly quadrate appendage from which spring a long falcate claw, and a curiously contorted two or three-jointed and flaccid process; the foot of the left side is two-branched, the inner branch extremely small, three-jointed and simple, the outer somewhat larger, fashioned in the normal manner but devoid of setæ, and bearing at the apex of the second joint a minute subulate process. The caudal segments (fig. 15) are about as broad as long, and equal in length to the last abdominal segment; the setr much shorter than the abdomen, except the fourth (counting from the outside), which is much stouter than, and about twice as long as, the rest.

Sir John Lubbock's measurement is 1-10th of an inch, Dana's 1-12th of an inch.

Habitat.-Off Cape Howe and Port Jackson, Australia; between Sydney and Wellington; between Api and Cape York; between Arrou and Banda; in very many places amongst the Philippine Islands; off New Guinea and North Australia; in the Pacific north of the Sandwich Islands; at Zamboanga, in the Arafura Sea ; off Kandavu, Fiji ; and in all the gatherings that I have examined from the tropical Atlantic, ranging between lat. $10^{\circ} \mathrm{S}$, and lat. $25^{\circ} \mathrm{N}$. 
In some gatherings the species was extremely abundant, more especially in those taken off South Australia and in the tropical Atlantic; and the red colour (brick-red) mentioned by Dana was distinctly observed in some samples, even after their prolonged immersion in spirit. These specimens are undoubtedly identical with those described by Sir John Lubbock as Undina longipes, and though Dana's figures are too small and his detailed descriptions too meagre for absolute certainty, I can scarcely doubt that they are meant to refer to this species : it would be strange if so widely spread and so abundant a species had escaped him, and if so that his species-likewise widely spread--should have also eluded the Challenger. Dana's drawing of the fifth foot of the male-the only characteristic detail which he gives - applies fairly well to our specimens, if we allow for the absence of minutiæ, consequent, perhaps, on the use of too low microscopic powers ; and I cannot recognise any distinction between the examples described by the same author under the three specific names, vulgaris, simplex and inornata.

One unmistakeable diagnostic mark of Undina longipes is the peculiar emargination of the second foot in both sexes - a mark quite sufficient for specific determination, even when no males may be present. The bidentate postero-ventral angle of the thorax, though perhaps not always present, is, I believe, another good specific character.

2. Undina darwinii, Lubbock (Pl. XVI. figs. 1-4, 6-14).

Undina darwinii, Lubbock, On some Oceanic Entomostraca collected by Captain Toynbee, Trans. Linn. Soc., vol. xxiii. p. 179, pl. xxix. figs. 4, 5.

Cephalothorax rounded off in front and behind, posterior ventral angle slightly exserted. Anterior antennæ of the female (figs. 3 and 4) twenty-five-jointed, the joints not varying much in length, except that the second is much larger than the rest; in the male (fig. 2) the antenna is twenty-two-jointed, angulated at the sixth joint, the first two joints long, equalling the following three or four joints; in both sexes the anterior antennæ are slightly longer than the cephalothorax, and clothed with marginal hairs which are very short except at the apex; the second and sixth joints, in the male, each bear a single long seta. The posterior antennæ have the two branches nearly equal in size the inner branch four-jointed, with two small and rather indistinct median joints. ${ }^{1}$ Mandibles broad at the apex (fig. 6), numerously and sharply toothed; basal joint of the palp very large, first joint of the inner branch swollen, both branches short and bi-articulate. Maxilla (fig. 7) well-developed, anterior foot-jaw small (fig. 8), posterior (fig. 9) well developed. The outer branches of the swimming feet are more or less strongly serrated between the last two marginal spines; the

${ }^{1}$ Fig. 5 pl. xvi. belongs to another species, and has been inadvertently included among the figures of Undina darwinii. 
first joint of the base in the third pair (fig. 10) has three small spines on the outer and a crescent-shaped row of six or eight similar spines towards the inner margin; the fourth pair is similarly armed as to the inner, but not as to the outer margin; the terminal spines of the feet are bent at the tips, as in Undina vulgaris, but are scarcely so slender, and the margins are not distinctly serrated. The right foot of the fifth pair in the male (fig. 11), is excessively long, the first two joints being nearly as long as the abdomen, and the extremity of the organ reaching as far as the very apices of the longest tail-setæ; the first basal joint-as also that of the left foot-has a serrated inner margin; the second joint gives attachment to a rudimentary, wedge-shaped inner branch, the smooth joint of the prehensile branch is produced externally into a very long slender and tortuous, immobile claw, which near the middle bears a small hook-like marginal process; the third joint is simple but has attached at its apex a large moveable appendix, shaped roughly like the letter E. The fifth foot of the female also has its first basal joint marginally serrated. The foot of the left side (fig. 12) is small, but otherwise does not much differ from the ordinary swimming feet, except in the absence of setæ on the outer branch. The female abdomen (fig. 14) has the distal borders of the first two joints more or less completely fringed with short setæ. The caudal stylets are as broad as long, and equal in length to the last abdominal segment; the fourth caudal seta is longer, and in the female much stouter than the rest-about once and a-half the length of the abdomen.

Length of the female, 1-10th of an inch $(2.55 \mathrm{~mm}$.), of the male, 1-12th of an inch $(2 \cdot 1 \mathrm{~mm}$.$) .$

Habitat.-Off Port Jackson, Australia; between Sydney and Wellington; between Api and Cape York; between Arrou and Banda; off the north of Papua; in several stations amongst the Philippine Islands ; Pacific, north of the Sandwich Islands ; lat. $36^{\circ}$ $32^{\prime}$ S., long. $132^{\circ} 52^{\prime} \mathrm{W}$. (Station 287) ; lat. $42^{\circ} 43^{\prime}$ S., long. $82^{\circ} 11^{\prime} \mathrm{W}$. (Station 302); lat. $36^{\circ} 44^{\prime}$ S., long. $46^{\circ} 16^{\prime} \mathrm{W}$. (Station 325); lat. $26^{\circ} 21^{\prime}$ N., long. $33^{\circ} 37^{\prime} \mathrm{W}$. (Station 353).

This is certainly one of the most remarkable as well as one of the most common of southern pelagic Entomostraca. Though not occurring amongst the Challenger gatherings quite so commonly as Undina vulgaris, its distribution seems to be pretty much the same, and in some of the bottles it was found very abundantly. The male is easily recognised, even with a simple hand lens, by the extraordinary length and grotesque form of the fifth foot. In all essential structural characters it agrees with the type-species, Undinc vulgaris, and I have given drawings of its various parts as illustrating the generic characters. The amount of ciliation of the female abdominal segments, and the apical pectination of the swimming feet vary very much in different examples. The immensely long fifth foot of the male would appear to be used partly to convey spermatophores to the vulva of the female. I have never actually seen these bodies attached to the limb (as is frequently observed in Euchota), but it is difficult to account in any other 
way for the frequent occurrence of spermatophores glued to the back of the female, usually on the penultimate thoracic ring. This I have seen so often, that I came to recognise the females of the species, under the hand lens, by that character alone. It is obvious that the fixture of a spermatophore in that situation. must be an entirely futile proceeding, but it is equally evident, from the abundance of the species, that plenty of spermatophores must get properly located. The males of Undina darwinii are extremely abundant, and must, if we take as a law the proportions of the sexes amongst other Copepoda, and especially amongst the species of the nearly allied genus Euchoeta-be far more than sufficient for the impregnation of the females. The competition for females will thus be very severe, and in the heat of the chase it seems very possible that miscarriages of the kind referred to may often happen. If this explanation be fanciful or wide of the mark, the fact of the common malposition of the spermatophores is, at any rate, an interesting one.

\section{Scolecithrix, ${ }^{1}$ n. gen.}

Undina, Lubbock (in part) Trans. Entom. Soc., 1856.

(?) Undina, Claus, Die frei lebenden Copepoden, 1863.

Head and thorax coalescent, rostrum short and furcate, posterior ventral angle of cephalothorax somewhat produced. Anterior antennæ in the female twenty to twenty-threejointed, in the male nineteen-jointed, not geniculated. Mandibles well developed. Inner branch of the maxilla very small. Inner (secondary) branch of the posterior antenna longer than the outer, its first joint imperfectly divided near the base, two small joints intercalated between it and the terminal joint. Anterior foot-jaw bearing at the apex, instead of the usual curved setæ, a bunch of thick flexuous (sensory?) filaments. Posterior foot-jaws nearly as in Calanus. Inner branches of the first pair of feet one-, of the second two-jointed, of the third and fourth pairs three-jointed, the first joint in all cases very small. Fifth pair of feet in the female wanting or rudimentary, in the male elongated and prehensile. Abdomen in both sexes four-jointed; no long tail seta.

Claus states that the first pair of foot-jaws in the male Undina messinensis are obsolete. This is certainly not the case in the typical Undina, nor is it so in the species which I have here referred to the new genus Scolecithrix. If it be really so in Undina messinensis, another genus must be established for the reception of that species, unless, indeed, it be referable to Euchota. Another important difference, noticed by Claus, is in the structure of the posterior antennæ, the outer branch of which is very much smaller than in any species of Undina or Scolecithrix known to me. 
1. Scolecithrix dance, Lubbock (Pl. XVII. figs. 1-12).

Undina dance, Lubbock, On some Entomostraca collected by Capt. Sutherland, Trans. Entom. Soc., vol. iv. 1856 , p. 15, pl. ix. figs. 6-9.

Cephalothorax robust (fig. 1), in the female usually not more than twice as long as broad, in the male somewhat more slender. Anterior antennæ (figs. 2,3) about as long as the cephalothorax, in the male nineteen-jointed, strongly arcuate, but not angulated, in the female twenty-jointed; the first two joints in both sexes are stout and of moderate length; they are followed by five very short and equal joints; the seventh joint in the female, the eighth in the male, is equal in length to the preceding five, and in some cases is indistinctly divided into four; the remaining joints do not vary greatly in length, except that the last (in the female) is very minute. Mandibles (fig. 5) rather narrow at the apex, basal joint of the palp large, smaller branch two-jointed, larger indistinctly divided into several joints. Inner branch of the maxilla (fig. 6, a) very small, composed of one or two (?) minute setiferous digits. The anterior foot-jaw (fig. 7) has four stout marginal processes, armed, as usual, with strong plumose setæ, the terminal joints bearing about six thick fusiform filaments, which are about half as long as the marginal setæ, and are filled with granular protoplasm. "Posterior foot-jaws well developed and formed like those of Calconus. Inner branches of the first pair of feet one-, of the second two-jointed, of the third and fourth pairs three-jointed, the first joint in all cases very small. Terminal spines of the swimming feet (fig. 8) strongly serrated on the outer and setose on the inner margin. Fifth pair in the female wanting, in the male (fig. 9) elongated, slender, that of the left side unbranched, the right bearing a simple one-jointed iennr branch, which opposes the clawed extremity of the outer branch. Abdomen in both sexes four-jointed, in the male slender, in the female (figs. 11, 12) short and stout, the first segment as large as the following three, tumid and prominent in front, where it is produced downwards, forming a pouch-like extension. Caudal segments distant, as broad as long, length about equal to that of the second or third abdominal somite; setæ sub-equal in length, not much exceeding that of the abdomen. Colour of the animal dark brown; length 1-11th of an inch $(2.3 \mathrm{~mm}$.).

The drawing of the female anterior antenna (fig. 3 ) is not quite accurate; no division should have been shown in the large first joint (though an imperfect one sometimes exists), and the last joint should have shown an extremely small segment at the apex. The large basal portion of the male antenna is, however, correctly given as divided into two.

Habitat.-Off Port Jackson, Australia; off Kandavu, Fiji ; between Api and Cape York; between Arrou and Banda; at several stations amongst the Philippine Islands ; off the east coast of Japan (Station 237); in lat. $32^{\circ} 24^{\prime} \mathrm{S}$., long. $13^{\circ} 5^{\prime} \mathrm{W}$. (Station 335); in lat. $9^{\circ} 43^{\prime} \mathrm{S}$., long. $13^{\circ} 51^{\prime} \mathrm{W}$. (Station 342); in several Atlantic stations from lat. $3^{\circ} 10^{\prime} \mathrm{N}$., long. $14^{\circ} 51^{\prime} \mathrm{W}$. to lat. $26^{\circ} 21^{\prime} \mathrm{N}$., long. $33^{\circ} 37^{\prime} \mathrm{W}$. (Stations $348-353$ ).

(ZOOL. CHALL. EXP.-PART XXIII.-1883.) 
The stout build, and-in the female-the very short abdomen of this species are almost sufficient to distinguish it at a glance from any other. On closer examination the most conspicuous character is the remarkably long eighth joint of the anterior antenna in both sexes; the joint is evidently formed by the coalescence of four into one, traces of this composition being, in some cases, quite distinct. The peculiar club-shaped filaments of the anterior foot-jaw may perhaps be olfactory organs; they seem at any rate to resemble appendages which have been so considered in other Crustacea, and from their situation it seems most likely that they are in some way subsidiary to alimentation.

The occurrence of a four-segmented abdomen in both sexes is a little remarkable, and though Sir John Lubbock's observation agrees with my own in ascribing only four joints to the male abdomen, I was at first suspicious of a mistake. On careful re-examination, however, I have been unable to see more than four joints in either sex, but the fourth in the female is often so smallas to be almost obsolete (see fig. 11). Sir John Lubbock describes the tail setæ as four in number, and in many cases I have not found more than that ; but in others (and this I suppose to be the normal condition) there is a very slender fifth seta, attached, I think, between the third and fourth.

This species, though not perhaps so abundant as Undina darwinii or Undina longipes, is often found associated with them, and in very considerable numbers.

2. Scolecithrix minor, n. sp. (Pl. XVI. figs. 15-16, and Pl. XVIII. figs. 1-5).

Length, 1-15th of an inch (1.6 mm.). Cephalothorax moderately stout, broadly rounded in front, postero-ventral angle acute, dorsal rounded off. Anterior antenna in the male nineteen-jointed, angulated at the tenth joint, eighth joint very long, in the female twenty-three-jointed, the large basal joint showing a faint trace of another articulation. The mouth-organs are almost exactly like those of Scolecithrix dano, but the maxilla (Pl. XVIII. fig. 3) is entirely destitute of an inner branch, and the anterior foot-jaws of the male (fig. 4) are much more sparingly setiferous. The feet of the fifth pair in both sexes are unbranched, in the female (Pl. XVI. fig. 16) minute, cylindrical, threejointed, the last joint furcate at the apex; in the male (fig. 15) the right foot is longer than the left, the last joint slender and bayonet-shaped, the antepenultimate bearing a rather long lateral adpressed process ; the left foot ends in a trifid (?) slender claw.

Habitat.-Scolecithrix minor was found only in a surface-net gathering from lat. $46^{\circ} 46^{\prime}$ S., long. $45^{\circ} 31^{\prime}$ E. (Station 146). In this bottle, however, it occurred in considerable abundance.

The comparatively small dimensions and apparently imperfect development of some of the parts of this animal led me to suspect that it might perhaps be only an immature form. But it can scarcely belong to Scolecithrix dance-the only known Copepod which possesses similar mouth-organs-the fifth pair of male feet being distinctly different. 
And I cannot suppose that the female would lose its fifth pair of feet in a more advanced stage of development, which must be the case if it be really a young Scolecithrix dana. Moreover, had it belonged to that species it would almost certainly have been noticed in some of the many gatherings in which Solecithrix dance occurred.

\title{
Euchota, Philippi.
}

\author{
Euchecta, Philippi, Archiv. f. Naturgesch., 1843 \\ " Dana, Proc. Amer. Acad. Sci., 1849. \\ " Claus, Die frei lebend. Copep., 1863. \\ Euchirus, Dana, Amer. Journ. Sci.
}

Head and thorax coalescent. Anterior antennæ twenty-four-jointed, those of the female provided with a few very long setæ, those of the male scarcely geniculated and bearing much shorter setæ. Forehead elongated, triangular, rostrum transversely notched or simply curved, not furcate. Eyes small, simple. Mandibles well developed in the female, biting portion wanting in the male. Maxillæ abnormal, the two branches almost coalescent, in the male very minute. Anterior foot-jaws short and stout, strongly setiferous, obsolete or entirely wanting in the male. Posterior foot-jaws very long and well developed, doubly geniculated and conspicuously projected from the body, very small in the male. Inner branch of the first pair of swimming feet one- (or two-) jointed, of the second pair one-jointed, of the third and fourth pairs three-jointed. Fifth pair wanting in the female, in the male much elongated, both limbs prehensile. Abdomen in the female composed of four, in the male of four or five segments; tail setæ in the male nearly equal, the second seta of the female, on each side, usually very long.

The eyes were not seen except in one or two of the specimens, having been mostly obliterated by immersion in alcohol, but from an indistinct glimpse of them in these examples they seem to be very minute, and situated almost immediately behind the rostrum. The last very minute joint (twenty-fourth) of the anterior antenna (in Euchoetce prestandrece) is called by Claus a tubercle, but I am unable to see any structural distinction between it and the other joints. The absence of the biting segment of the male mandible is a very remarkable, and, so far as I know (with the single exception of Calanoides, a new genus described further on), a unique character amongst the Gnathostomata. It is not noticed by Claus or by any other author, but I have carefully dissected many specimens of Euchceta prestandrece and other species, and have never been able to find a trace of that structure, except in the case of Euchcetc australis, where there is a doubtful rudiment of it. The very feeble development of the male maxillæ and foot-jaws, together with the absence of the mandible, and sometimes also of the first foot-jaw, points perhaps to the conclusion that the life of the creature is a very short one, death possibly following speedily the act of copulation. We seem to have here a case of retrograde development, 
differing only in degree from those well-known and more conspicuous examples found amongst the lower parasitic Copepoda and the Cirripedes.

I observed in several cases-and this is noticed also by Claus-the attachment of spermatophores to one of the fifth feet of the male (see Pl. XVIII. fig. 13, a). There can be little doubt, I suppose, that this is the mode in which the fertilising element is transferred to the generative system of the female; the spermatophores are quite commonly seen affixed to the vulva. I have not noticed the club-shaped sensory appendages of the anterior male antennæ which are figured and described by Claus, but though those organs are frequently present in the males of most Calanoid Copepoda, their number and size are extremely variable even in the same species. Indeed it seems to me very probable that they are subsidiary sexual organs, adapted for some temporary purpose, and, that purpose being fulfilled, that they-if the animal lives long enough-may drop off or become atrophied. On the other hand, those males which are without them are probably, in the majority of cases, individuals not yet arrived at sexual maturity.

The genus is very widely distributed, indeed almost ubiquitous, except perhaps in the Arctic and Antarctic, and in the colder parts of the temperate seas. The number of species, however, seems to be small, several of those described by Dana being, as I believe, founded upon different stages of growth of the same animal. The most conspicuous generic characters are, in the female, the very long, scattered setæ of the anterior antennæ, the absence of the fifth pair of feet, and the large doubly geniculated posterior footjaws; in the male, the long prehensile feet, the absence of the mandibles, and the absence or atrophy of the first pair of foot-jaws. I strongly suspect that the notched rostrum will be found to characterise one species only-Euchceta prestandrece. At any rate the genus as here defined includes some species which have neither that character nor the single long caudal seta.

1. Euchceta prestandrece, Philippi (Pl. XVIII. figs. 7-15 (male), and Pl. XIX.).

$?$ Euchata prestandrece, Philippi, Arehiv f. Naturgesch. (1843), Taf. iv. fig. 5.

" $\quad$ Claus, Die frei lebenden Copepoden, p. 183, pl. v. fig. 12, $a$, pl. ix. figs. $6,7,9,12, \mathrm{pl}$. xxx. figs. 8-17.

" communis, Dana, Proc. Amer. Acad. Sci. (1849) and Crust. U. S. Expl. Exped., p. 1086, pl. lxxvii. fig. 1, $a-e$, and fig. $2, a-e$.

? " concinna, Dana, Crust. U. S. Expl. Exped., p. 1088, pl. lxxvii. fig. 4, $a-b$, and

fig. $5, a-c$.

? pubescens, Id. Ibid. p. 1090, pl. lxxvii. fig. 6, $a-g$.

" atlantica, Lubbock, On some Entomostraca collected by Dr. Sutherland, Trans. Entom.

" sutherlandii, Id. Ibid. p. 14, pl. ix. figs. 1, 2.

Length, 1-8th to 1-5th of an inch (3-5 mm.). Rostrum transversely notched and forming two sharp teeth. Anterior antennæ of the female rather longer than 
the cephalothorax, twenty-four-jointed, many of the joints laterally produced and angulated at the apices, the third, seventh, eighth, thirteenth, seventeenth, twentieth, and twenty-second joints each bearing a very long apical seta, equal in length to about one-third of the antenna; the twenty-third joint (penultimate) has two long and two or three shorter setæ, and in addition to the long setæ the intermediate joints have mostly one or more short ones. In the male the anterior antenna is slightly angulated at the twelfth joint (Pl. XVIII. fig. 8), thickly fringed with short setæ near the base, more sparingly beyond, and has likewise a few scattered longer setæ; these, however, are not nearly so long as in the female; the eighth and ninth joints are coalescent. The mandible in the female (Pl. XIX. fig. 4) is broad and strongly toothed at the apex, palp large, with a broad base and two short biarticulate branches: in the male (Pl. XVIII. fig. 9) there is no biting segment, and the palp is very small : the outer branch of the maxilla is obsolete (Pl. XIX. fig. 5, and Pl. XVIII. fig. 10), and the whole limb is in the male minute. The anterior foot-jaws are of moderate size in the female, but rudimentary in the male. Posterior foot-jaws very large in the female (Pl. XIX. fig. 7), with two long basal and five small apical joints, very small in the male (Pl. XVIII. fig. 12). The outer branches of all the swimming feet are three-jointed, except that of the first pair in the female, which is only two-jointed (Pl. XIX. fig. 8). The inner branches of the third and fourth pairs in both sexes are three-jointed. That of the first pair in the female has one joint only, in the male one (or sometimes two) joints. In both sexes the inner branch of the second pair has only one joint. The fifth pair of the male (Pl. XVIII. fig. 13) are of equal length, that of the left side simple, ending in a very long subulate joint, the basal joint bearing a rudimentary rod-shaped inner branch which is as long as the second joint; the terminal joint of the right foot has one long and slender apical spine and another much smaller one ; it has also, springing from its inner margin, a stout appendage, which is dilated and toothed at the apex and fringed on the margin with minute hairs; in the axil between this and the main portion of the limb is a small conical ciliated process. (The immature fifth feet of Euchceta sutherlandii, Lubbock, are represented in fig. 14). The abdomen is sometimes slightly pubescent, the last segment in both sexes always very short, the second caudal seta of the female is extremely long, often longer than the whole body of the animal, the others variable in length but not longer than the abdomen. The two branches of the posterior antennæ (Pl. XIX. fig. 3) are nearly equal in length; the inner branch four-jointed, first and third joints very short, bearing three apical and four lateral setæ. The second pair of feet in both sexes (Pl. XIX. fig. 9) differs from the rest in having the spine-bearing angles elongated into small finger-like processes. The serratures of the terminal spines of all the feet are extremely delicate, about fifty or more on each spine. The external egg-masses are not enclosed in a definite sac, but are loosely aggregated like bunches of grapes.

Habitat.-Off Port Jackson, Australia ; between Sydney and Wellington ; off Kan- 
davu, Fiji ; between Api and Cape York; between Arrou and Banda; off the north and south coasts of Papua ; Arafura Sea ; lat. $46^{\circ} 46^{\prime}$ S., long. $45^{\circ} 31^{\prime}$ E. (Station 146) ; lat. $47^{\circ} 25^{\prime}$ S., long. $130^{\circ} 32^{\prime}$ E. (Station 159); in several places amongst the Philippine Islands; between Japan and Honolulu ; Pacific, north of the Sandwich Islands ; lat. $42^{\circ}$ $43^{\prime}$ S., long $82^{\circ} 11^{\prime} \mathrm{W}$. (Station 302) ; lat. $36^{\circ} 44^{\prime}$ S., long. $46^{\circ} 16^{\prime} \mathrm{W}$. (Station 325); lat. $37^{\circ} 45^{\prime} \mathrm{S}$., long. $33^{\circ} 0^{\prime} \mathrm{W}$. (Station 330 ) ; in many gatherings from the tropical Atlantic between lat. $12^{\circ} 16^{\prime} \mathrm{S}$., long. $13^{\circ} 44^{\prime} \mathrm{W}$. (Station 341 ) and lat. $32^{\circ} 41^{\prime} \mathrm{N}$., long. $36^{\circ} 6^{\prime} \mathrm{W}$. (Station 354).

If the Challenger collections may be taken as a fair indication, this would seem to be the most abundant and most widely distributed of all the pelagic Copepoda.

At the same time the possibility must be admitted of more than one species being included in the series which I here refer to Euchceta communis. In very many gatherings, though females were abundant no males could be found, and on the characters of the latter sex perhaps some specific distinctions might have been based. As to the females, I have not found any variations which appeared to me of specific value. The form of the male described by Sir John Lubbock as Euchoeta sutherlandii, occurs not uncommonly, and I do not doubt is simply the immature male of Euchceta prestandrece; this view is also taken by Dr. Claus. And though it is difficult to decide the point absolutely from Dana's drawings and descriptions, I believe that the same remark applies to his Euchata concinna. Nor do I find any sufficient marks to warrant the separation of Euchceta pubescens: the characters given as belonging to this last species I have found not unfrequently in what I take to be mere varieties of Euchata prestandrece. It would indeed be wonderful if a species so widely distributed did not present many varieties dependent upon race and external conditions.

If I am right in regarding all Euchcetce with a notched rostrum and a single elongated tail seta as belonging to one species, we may fairly identify it with that described by Philippi as Eucheta prestandrece; but no other characters of specific value are noticed by that author. Dr. Claus, at any rate, has referred to Euchceta prestandrece, the Mediterranean species figured in his work, which is undoubtedly also identical with Lubbock's Euchceta atlantica. There is more doubt about the reference to Dana's Euchceta communis, though there is nothing in the figures or descriptions, except insufficiency of detail, to discredit that reference. It is scarcely possible that a species so common and widely distributed as that now under discussion should have been missed by Dana: and a more appropriate term than communis could hardly have been applied to it, but if, as appears likely, Philippi's name referred to the same species, it has the claim of priority in date. 
2. Euchata hessei, n. sp. (Pl. XX. figs. 1-13, and Pl. XXIII. figs. 11-14).

Anterior antennæ nearly as long as the body, twenty-three-jointed in the male, twenty-four-jointed in the female, the last joint half as long as the preceding one, provided with long setæ at the apices of the third, seventh, eighth, thirteenth, twenty-third, and twenty-fourth joints, and with very short setæ on the intermediate joints; rostrum long and simply curved; in the female there is a very small terminal joint, but this is wanting in the male, its place being supplied by a few setæ and a pyriform sensory appendage. Posterior anteunæ (Pl. XX. fig. 3) as in Euchcetc prestandrece; those of the female more densely setose than in the male. Mandibles and anterior foot-jaws (figs. 4, 8,9) as in Euchceta prestandrece. External branch of the maxilla-palp in the female (fig. 5 a) rudimentary, inner branch (b) elongated, digitiform; in the male (fig. 6), the maxilla is very small, the biting portion altogether wanting. The anterior foot-jaw is wanting in the male, but in the female (fig. 7), has the innermost seta of each digit pectinated near the base with a row of short rigid setæ, the rest of the setæ simply plumose : the last seta of the second joint of the posterior foot-jaw bears also a marginal comb-like row of cilia. The structure of the swimming feet is exactly as in Euchota prestandrea, except as to the terminal spines (fig. 10), which are much more strongly serrated, the number of serratures being from twenty to twenty-two on each spine. The basal joints of the fourth pair of feet in the female (fig. 10, $a$ ) are armed on their internal margins with a comb-like row of about five very broad and strong spines. The fifth pair of feet of the male (fig. 11) does not possess any toothed appendage, but in other respects is much like that of the preceding species. The abdomen in both sexes is fourjointed, but much shorter and stouter in the female (figs. 12, 13). Caudal stylets about as long as broad; setæ nearly equal in both sexes, scarcely longer than the abdomen. Length, 1-8th of an inch $(3.1 \mathrm{~mm}$.). The two specimens taken between Japan and Honolulu were twice this length.

Habitat.-This species was found in a gathering from lat. $38^{\circ} 7^{\prime}$ S., long. $94^{\circ} 4^{\prime} \mathrm{W}$. (November 6th, 1875, near Station 295). The captures of Copepoda in this Station consisted almost entirely of two species in about equal numbers:-Euchota hessei and Calanus valgus. It occurred also amongst surface animals from lat. $36^{\circ} 32 \mathrm{~S}$., long. $132^{\circ}$ $52^{\prime} \mathrm{W}$. (Station 287). Two specimens were found in a surface gathering made between Japan and Honolulu, and a few at Station 352 , lat. $10^{\circ} 55^{\prime} \mathrm{N}$., long. $17^{\circ} 46^{\prime} \mathrm{W}$.; between Api and Cape York; and at a Station near the Philippine Islands (January 9th, 1875).

\section{Euchceta pulchra (Lubbock), (Pl. XIV. figs. 6-9, Pl. XX. figs. 14-19).}

Undina pulchra, Lubbock, On some Entomostraca collected by Dr. Sutherland, Trans. Entom. Soc., vol. iv., 1856, pl. iv. figs. 5-8, and pl. vii. fig. 6 .

Length, 1-6th of an inch $(4 \cdot 2 \mathrm{~mm}$.). Cephalothorax robust, rounded in front, obtusely angulated behind, rostrum short, simply curved. Anterior antennæ as long 
as the body, twenty-four-jointed, very sparingly provided with long setæ. Posterior antennæ, mandibles, maxillæ, foot-jaws, and swimming feet as in the preceding species. Terminal spines of the swimming feet strongly serrated, very similar to those of Euchata hessei. Fifth pair of feet of the male (fig. 17) elongated, that of the left side simple, slender, not clawed; on the right side ending in two very long, slender, opposable claws, one of which is armed with a series of small marginal tooth-like tubercles, the other with several larger angulated protuberances. The abdomen of the male is four-jointed, of the female three-jointed, the first joint having a hook-like process on the dorsal surface. Caudal segments very short, setæ stout, subequal, about as long as the abdomen, and densely plumose.

Habitat.-Taken in the North Atlantic at night, near Station 353, May 7, 1876, about lat. $27^{\circ} \mathrm{N}$., long. $33^{\circ} \mathrm{W}$. Though many specimens of Euchota pulchra occurred in this gathering, I have not seen it in any other, and this is, I think, the only instance amongst the Challenger collections in which the night captures have yielded any peculiar species. Amongst the Copepoda there does not, indeed, appear to be so great a difference between nocturnal and diurnal species as there is amongst some other tribes of pelagic Crustacea.

\section{Eucheta (?) philippii, n. sp. (Pl. XXI. figs. 1-4).}

Female (?)-Length, 1-4th of an inch $(6.2 \mathrm{~mm}$.). Cephalothorax robust, broad in proportion to the length. Anterior antennæ (fig. 2) about as long as the cephalothorax, twenty-five-jointed, second joint much larger than the rest, which are not very unequal in length, the whole limb profusely clothed with more or less adpressed hairs, those of the last eight joints longer than the others. The chief terminal spines of the swimming feet (fig. 3) are very coarsely serrated, having only about twelve serrations; the larger of the secondary spines unusually well developed, at least half as long as the principal spine, and densely ciliated. There is a rudimentary fifth pair of feet (fig. 4), extremely small, and composed of two obtuse, cylindrical branches.

Habitat. - A very few specimens only were noticed amongst the captures from lat. $36^{\circ}$ $44^{\prime}$ S., long. $46^{\circ} 16^{\prime} \mathrm{W}$., depth 2650 fathoms (Station 325 ), and a few, probably referable to the same species, from Station 288 (lat $40^{\circ} 3^{\prime} \mathrm{S}$., long $132^{\circ} 58^{\prime} \mathrm{W}$.). This species is only provisionally assigned to the genus Euchceta. The mouth-organs-mandibles and footjaws - are exactly those of the normal female Euchata, but the presence of a fifth pair of feet, though very small, is abnormal. If a male this specimen certainly cannot be rightly referred to Euchata, inasmuch as the mandibles, maxillæ, and foot-jaws are fully developed. The anterior antennæ and the spines of the swimming feet present wellmarked specific characters, and are quite unlike those of any other species known to me. 


\section{Euchata australis, n. sp. (Pl. XXI. figs. 5-11).}

Length, 1-6th of an inch $(4 \cdot 2 \mathrm{~mm}$.). Cephalothorax elongated, robust; anterior antennæ as long as the body, in the female twenty-four- in the male twenty-one- (?) jointed; the basal joints more or less villous; in the female several of the joints bear single long apical setæ, the rest have two or more very short hairs; in the male (fig. 6) there are no excessively long setæ, and the shorter ones are but few. The terminal spines of the swimming feet (fig. 11) are not so coarsely serrated as in Euchcetc phitippii, the serræ being about twenty-five on each spine; and the secondary spines are quite small. The general characters of the feet and mouth-apparatus in both sexes are those of a normal Euchota. The first abdominal segment of the female (fig. 10) is serrated at the outer angles, the caudal stylets are about as long as broad, the tail setæe equal and densely plumose.

Habitat.-Between Api and Cape York; and in a deep-sea gathering down to 2650 fathoms, lat. $36^{\circ} 44^{\prime}$ S., long. $46^{\circ} 16^{\prime}$ W. (Station 325).

It is of course impossible to say at what depth the specimens brought up in the net from 2650 fathoms were really caught, but as one at least of the species belonging to this gathering (Euchceta gigas) has been found in no other, it seems probable that they were brought from a great depth; and I entertain no doubt whatever that it is from the abyssal water and from the bed of the sea itself in those regions, as well as in more moderate depths, that we must now hope to obtain interesting or novel examples of Copepoda. In some specimens of Euchoeta australis there was a brightly refracting spot near the middle of the first body-segment, which may perhaps be a pleural eye, but I was unable to obtain a sufficiently distinct view to satisfy myself as to its nature.

\section{Euchoeta gigas, n. sp. (Pl. XXII. figs. 1-5).}

Length, 22-100ths of an inch $(5 \cdot 25 \mathrm{~mm}$.). Female.-Body robust, obtusely angulated in front, posterior lateral angles of the thorax armed with sharp slender spines: anterior antennæ (fig. 2) as long as the cephalothorax, twenty-three-jointed, joints from the third to the seventh very short, eighth about twice as long, last six joints the longest; the limb is provided throughout its whole length with marginal setæ, none of which are excessively long. The teeth of the mandible (fig. 3) are very strong, the two larger ones with falcate apices. The terminal spines of the swimming feet (fig. 4) are closely and finely serrated on the outer, and very densely setose on the inner margin. Abdomen four-jointed, short; caudal stylets very short, broader than long; tail setæ four, spreading; subequal, very densely plumose, not longer than the abdomen.

Habitat.-Lat. $36^{\circ} 44^{\prime}$ S., long. $46^{\circ} 16^{\prime} \mathrm{IV}$., down to 2650 fathoms (Station 325).

(ZOOL. CHALL. EXP.-PART XXIII-1883.) 
Very few specimens only were seen, and I am not quite certain as to the sex of some of these. The mandible, I think, was present in all the specimens I have examined, and if so the species will probably have to be referred to some other genus than Euchota, seeing that in one example a fifth pair of feet (fig. 5), apparently those of an immature male, was observed. The structure of the swimming feet, however, as well as of the other mouth-organs agrees entirely with the normal Euchceta.

\section{Eucheta barbata, n. sp. (Pl. XXII. figs. 6-12).}

Length, 1-3rd of an inch (8.4 mm.). Female.-Anterior antennæ very slender (fig. 6), twenty-three-jointed (?), the fourth, eighth, ninth, and thirteenth joints each bearing an extremely long seta, the seventeenth and twenty-third joints having setæ of moderate length. The rostrum (fig. 7) and the posterior ventral angle of the thorax (fig. 12) have beard-like tufts of setæ, and so also has the last joint of the abdomen. The longer setæ of the first pair of foot-jaws (figs. 8-10) are ringed and densely pectinater, while the processes which bear the shorter (proximal) setæ are clothed with fine hairs (fig. 9). The feet are constructed exactly as in the normal Euchoetc, but the terminal spines are extremely slender (fig. 11) and very finely serrated. Abdomen moderately long (fig. 12), four-jointed, the first joint very large and angularly protuberant in front; caudal setæ subequal, densely setose, about as long as the abdomen.

Habitat.-Lat. $36^{\circ} 44^{\prime} \mathrm{S}$., long. $46^{\circ} 16^{\prime} \mathrm{W}$., down to 2650 fathoms (Station 325). This fine species, of which only one example was seen, is sufficiently distinguished from all others by the beard-like appendages of the forehead and thorax, the armature of the first foot-jaw, the very slender apical spines of the swimming feet, and by the characters of the anterior antennæ.

\section{Candace, Dana.}

Candacia, Dana, Amer. Journ. Sci., 1846.

Ifionyx, Kröyer, Nat. Tidskr., 1849.

Cardace, Dana, Crust. U. S. Expl. Exped., 1852.

Head consolidated with the first thoracic segment. Anterior antennæ twenty-threeor twenty-four-jointed, that of the male on the right side geniculated, and having the median joints only slightly swollen. Posterior antennæ stout, main stem composed of a large base and a small bilobed apical joint, secondary branch two-jointed, first joint almost obsolete. Mandibles twisted, narrow, ending in two stout teeth, the palp very much expanded. Maxilla bearing a long styliform process, masticatory portion subtriangular. First pair of foot-jaws very large and having long uncinate setæ, second pair very small, seven-jointed. Inner branches of the swimming feet two-jointed. 
Fifth pair of feet in the female composed of one triarticulate branch on each side ; those of the male dissimilar, the right usually prehensile. Abdomen composed in the female of three, in the male of five somites. Rostrum short and rounded.

The chief distinctive characters of the genus Candace are found in the very largely developed anterior, and almost obsolete posterior foot-jaw ; the armature of the anterior, consisting of numerous very strong non-ciliated uncinate setæ. The right antenna of the male is always strongly geniculated, swollen in the middle, and usually provided with dentated marginal plates, and several of the basal joints are strongly toothed on the outer margin. The first abdominal somite in the adult female is often greatly swollen and angulated. The eyes are two lateral refracting bodies with one unpaired central ocellus. The external margins of the outer branches of the swimming feet are often finely pectinated, and those of the third and fourth pairs coarsely serrated towards the apex.

The genus is widely distributed, often occurring in considerable numbers. Its members may usually be distinguished at a glance, often even without the help of a lens, by the deep brown or black colouring which pervades parts, or sometimes the whole, of the body. The parts most liable to this coloration are the swimming feet, the anterior part of the long antennæ, and the cephalothorax. Only rarely is a specimen found entirely without colouring, some tinge of brown being almost universally visible in the tips of the various spines, or in the plumes of the feet, even when the rest of the animal is colourless.

1. Candace pectinata, Brady (P1. XXX. figs. 1-13).

Candace pectinata, Brady, Monog. Brit. Copep., vol. i. p. 49, pl. viii. figs. 14, 15, and pl. x. figs. 1-12.

Length, 1-8th of an inch $(3.1 \mathrm{~mm}$.). Cephalothorax (figs. 1, 2) robust, truncated in front, scarcely at all tapered towards the extremities, posterior lateral angles produced into strong spines. Anterior antennæ as long as the cephalothorax (fig. 3), twentythree-jointed, several of the basal joints (third to seventh) bearing strong marginal teeth; the setæe are irregular in size, those at the apex of some joints being very long, the rest comparatively short; in the male (figs. 4-6) the seventeenth joint of the right antenna (that on the proximal side of the hinge) bears a strongly pectinated crescentic marginal plate, the central teeth of which are the largest; the sixteenth joint is minutely pectinated, and the eighteenth bears a short beard-like fringe of setæ; several of the basal joints bear short, club-shaped sensory filaments; joints from the seventh to the eleventh on the right side, - seventh to tenth on the left side (and on both sides in the female), very small. The terminal spines of the third and fourth pairs of swimming feet are usually twisted at the apex; the inner branches, and the inner halves of the outer branches (figs. 7,8 ), are mostly coloured brown or black, the setæ also deeply coloured 
and densely plumose. The right foot of the fifth pair in the male (figs. 9, 10) is shorter than the left, and ends in a prehensile hand, one limb of which is broad and rounded, bearing two or three short apical setæ, the other forms a falciform claw; the foot of the left side consists of four nearly equal joints, the last two being more or less copiously ciliated. In the female, the feet of the fifth pair (figs. 11,12) are cylindrical, three-jointed, the last joint elongated, subulate, and bearing two or three apical teeth. In the adult female the first abdominal segment (fig. 1) is usually produced at each side into a triangular prominence; the caudal stylets are extremely small, the setæ spreading, subequal, and about as long as the abdomen. The male abdomen (fig. 13) has the first somite produced on the right side only, forming a large spine-like acutely-angular projection.

Habitat.-Candace pectinata occurred in very many of the Challenger surface gatherings, often in considerable abundance. The species has a wide range of distribution, ranging from Australia in the south-east to the Scilly Islands in the northwest. Though so common a form, I cannot identify it with any of the species described in Dana's great work, probably on account of the insufficiency of the descriptions there given. It is the only member of the genus which has been met with in the British Seas, but does not appear among the Mediterranean species described by Dr. Claus.

The following are the localities of the Challenger captures :-off Cape Howe, Australia; off Port Jackson; between Sydney and Wellington; between Api and Cape York; in various places about the Philippine Islands; and at several Atlantic Stations between Ascension and the Azores.

2. Candace pachydactyla, Dana (Pl. XXXI. figs. 2-9).

Candace pachydactylu, Dana, Crustacea U. S. Expl. Exped., p. 1113, pl. Ixxviii. fig. 2, a.b.

Length, 1-8th of an inch $(3.1 \mathrm{~mm}$.). In general form like Candace pectinata. The apical portion of the anterior antennæ (figs. 2,3 ) is usually deeply coloured ; the coalesced seventeenth and eighteenth joints of the right male antenna (figs. 3, 4) are densely pectinated with short, rigid setæ, and the nineteenth joint bears a shorter series of similar setæ; relative sizes of the joints as in the preceding species. The outer branches of the swimming feet have the last joint only deeply coloured throughout, the inner branches are uncoloured; the terminal spines usually short and twisted. The right foot of the fifth pair in the male (fig. 6) is prehensile, the second joint forming a blunt, falciform claw, which opposes a broad, ovate third joint; the foot of the left side is longer, fourjointed, the two terminal joints sparingly setiferous; in the female (fig. 8) the fifth pair of feet are stout, three-jointed, the last joint divided at the apex into three stout teeth, bearing a few short marginal setæe, and on the middle of the outer margin a single tooth. The abdomen of the male (fig. 9), like that of Candace pectinata, forms on the right side 
a strong spinous projection, which nearly meets a corresponding spine of the right thoracic angle.

Habitat.-Off Port Jackson, Australia; between Sydney and Wellington; off Kandavu, Fiji ; Philippine Islands; lat. $36^{\circ} 48^{\prime}$ S., long. $39^{\circ} 36^{\prime} \mathrm{W}$.; several stations in the Atlantic, between lat. $10^{\circ} \mathrm{S}$. (near Ascension Island) and $27^{\circ} \mathrm{S}$. (west of the Canaries).

From the list of localities it will be seen that the distribution of this species is almost identical with that of Candace pectinata. The points of difference between the two are to be found in the style of armature of the right male antenna, and in some slight divergences in the fifth feet of both sexes. And, as far as I have been able to observe, the distribution of colouring in the swimming feet affords a good diagnostic mark; in Candace pectinata the colouring extends over only half the breadth of the outer branch, but (usually) over the whole of the inner branch; in Candace pachydactyla the whole of the last joint of the outer branch is coloured, while the inner branch is altogether colourless.

Several male specimens showed an immature form of the fifth pair of feet (fig. 7 ), and in these the anterior antennæ had not taken on the special characters of the male. ${ }^{1}$

3. Candace truncata, Dana (Pl. XXVIII. figs. 12-15, and Pl. XXIX. figs. 1-14).

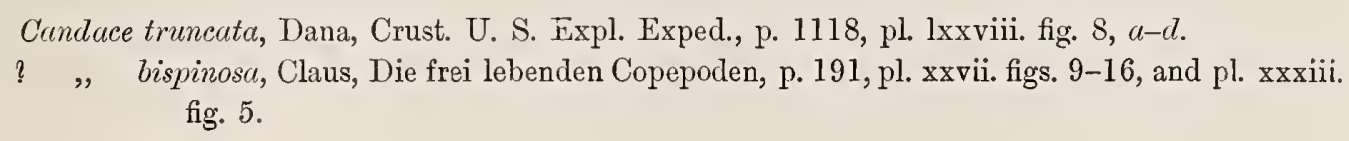
fig. 5 .

Length, 1-12th of an inch $(2 \cdot 1 \mathrm{~mm}$.). Cephalothorax truncated both in front and behind, posterior lateral angles rounded off or obtusely angular, not spined, anterior antennæ twenty-four-jointed, the joints more nearly equal in length than in the foregoing species; several of the basal joints (fig. 4) bearing long, slender spines. The right anterior antenna of the male (fig. 2) has no denticulated plates, and the joints, both on the distal and proximal sides of the hinge, are nodose at their apices. Outer margins of the swimming feet very finely serrated. Terminal spines of the swimming feet (figs. 7, 8) nearly straight (rarely twisted). Fifth pair of feet of the male (fig. 9) nonprehensile, that of the right side simple, three-jointed, short, bearing a long straight, plumose, apical setæ, which reaches as far as the apex of the left foot; left foot fourjointed, sparingly setiferous at the apex. The fifth pair of feet in the female (fig. 10) is small, the last joint elongated, with two small apical and two marginal teeth, and on the inner margin two or three setæ. The first somite of the female abdomen has large triangular lateral processes, that of the male is simple. Animal usually colourless.

1 Sir John Lubbock, in his paper on the Entomostraca collected by Dr. Sutherland (Trans. Entom. Soc., 1856), appears to have made his drawings of Candace pachydactyla from a male of that species and a female of Candace truncata, himself expressing a suspicion that more than one species were mixed together in his material. 
Habitat.-Between Api and Cape York; off Kandavu, Fiji ; off south coast of Papua ; at several Stations off the Philippine Islands; Pacific, north of Sandwich Islands ; Atlantic, lat. $27^{\circ} \mathrm{N}$. ; lat. $46^{\circ} 46^{\prime} \mathrm{S}$., long. $45^{\circ} 31^{\prime}$ E. ; lat. $64^{\circ} 37^{\prime}$ S., long. $85^{\circ} 49^{\prime}$ E.; lat. $9^{\circ} 43^{\circ}$ S., long. $13^{\circ} 51^{\prime} \mathrm{W}$.

The slender, straight spines and exceedingly fine serrations of the swimming feet, the absence of denticulated plates on the right male antenna, the non-prehensile fifth feet of the male, and the usual colourlessness or very sparing coloration of the animal, serve to distinguish this from any other described species. Except in the structure of the fifth pair of feet in the female, the species described by Claus as Candace bispinosa seems to agree entirely with Candace truncata. The specimens from which my drawing (PI. XXIX. fig. 11) was made, occurred in a gathering from the Atlantic, north of Ascension Island, and are undoubtedly identical with Candace bispinosa, Claus; but I have not been able to detect any other character separating them from Candace truncata, Dana, and therefore prefer, for the present at any rate, to consider them as a variety of that species.

Dana's statement of a "twenty- to twenty-two-jointed" antenna does not apply to this species, but the joints near the base of the limb are often difficult to see, and almost impossible to count correctly with low powers of the microscope. The figures here given (Pl. XXIX. figs. 1, 3) show different numbers of joints, fig. 1 having been drawn with a low power and left uncorrected, fig. 3 with a higher power. One of the diagnostic marks given by Dana-- "second joint stout, not longer than third or fourth," -would thus apply to our fig. 1, but not to fig. 3 .

\section{Corynura, ${ }^{1}$ n. gen.}

Cephalothorax slender, cylindrical, head coalescent with first thoracic somite, abdomen fire-jointed in the male, three-jointed in the female. Right anterior antenna of the male geniculated, and provided with serrated plates. Mandible-palp bearing two small onejointed branches. Maxilla destitute of a palp, composed of a stout setiferous base and a slender, one-jointed apical portion. Anterior foot-jaw as in Acartia, excepting that the setæ are for the most part not plumose; posterior foot-jaws also like those of Acartia, but that the apical portion is rudimentary and uniarticulate. Fifth pair of feet simple, unbranched, in the male prehensile. Caudal stylets much elongated, and dilated at the apices. One large eye (?) situated in the front of the forehead.

The anterior antennæ and fifth pair of feet are closely similar to the same organs in Pontella, but the peculiar structure of the maxillæ, the unjointed (or very indistinetly jointer) and rudimentary apex of the posterior foot-jaw, together with the remarkably 
elongated abdomen and tail are characters of sufficient importance to demand generic recognition. In the very largely developed posterior foot-jaw there is a resemblance to Candace.

\section{Corynura gracilis, n. sp. (Pl. XXXIII. figs. 1-14).}

Length, 1-12th of an inch $(2 \cdot 1 \mathrm{~mm}$.). Abdomen slender, very much narrower than the cephalothorax (fig. 1), head marked by a deep transverse groove. Anterior antennæ slender, not quite as long as the body; fifteen-jointed (?) somewhat nodose and furnished with rather long setæ,--sparsely, except at the apex, which bears a brush of five or six long, and, in the male, finely plumose hairs. Two joints on the proximal, and one on the distal side of the hinge joint in the male, are very finely denticulated, and in the middle of the swollen portion of the limb is a strong, deflexed, marginal tooth; the last denticulated joint also has a spine at the apex. Inner branch of the posterior antenna (fig. 5) of moderate length. Mandible (fig. 6) deeply and sharply toothed, the teeth densely ciliated, palp bearing two short, one-jointed branches. Basal portion of the maxilla (fig. 7) stout, bearing a series of eight or nine ciliated setæ, apical portion simple, with three curved terminal setæ. Apical portion of the posterior foot-jaw (fig. 9) very indistinctly three-jointed, rudimentary, feebly setiferous at the extremity. Swimming feet like those of Acartia, except that the marginal spines are distinctly articulated to the limb. Fifth pair of feet in the female (fig. 12) simple, two-jointed, the last joint curved, awl-shaped, slightly dentated at the apex; in the male strongly hooked and prehensile. The tail is very long, constricted at the base (figs. 13, 14) and, in the female dilated and spathulate at the apex; in the male it is slender, dilated at the apex, but without any marked basal constriction; there is a small marginal hair on the middle of each caudal stylet; the terminal setæ are much shorter than the abdomen and subequal.

Habitat.-This remarkable species was found in four gatherings from near the Philippine Islands, in all cases rather sparingly.

The jointing of the anterior antennæ, especially near the base, is very indistinct, and it is impossible, from spirit specimens at any rate, to state with accuracy the number of the joints. The same remark applies very frequently to Pontella and other allied genera.

\section{Corynura barbata, n. sp. (Pl. XXXI. figs. 10 12).}

Female.-Like the preceding, except that the caudal stylets (fig. 12) are shorter and stouter, and have a long seta on the middle of the external margin. The anterior antennæ are very obscurely jointed, and the fifth pair of feet (fig. 11.) are unequal in size, the larger one angularly produced in the middle, and bearing on the projection a shaggy setose fringe. 
One spccimen only was found amongst the Copepoda from Zebu Harbour, Philippine Islands. The parts were not very clearly made out on dissection, but so far as appears, the individual is not referable to any known species.

\title{
Acartia, Dana.
}

\author{
Acartia, Dana, Amer. Journ. Sci., 1846. \\ Dias, Lilljeborg, Crust. ex. ord. trib., 1853. \\ " Claus, Die frei lebend. Copep., 1863. \\ " Boeck, Oversigt Norges Copepoder, 1864. \\ " Brady, Monog. Brit. Copep., 1878.
}

Body long and slender, head produced into a slender rostrum, abdomen composed in the male of five, in the female of three, segments. Antcrior antennæ in the female twenty-jointed, bearing scattered long setæ, nodose, and in the male, on the right side, geniculated. External branch of the posterior antenna long, three-jointed; internal branch short, onc-jointed. Labium very large, three-lobed, setiferous, the middle lobe very broad. Mandible-palp of moderate size, two-branched, branches short, one- or twojointed. Anterior foot-jaws large, bearing numerous uncinate setæ, which are pectinated as in Pontella; posterior composed of a broad basal, and a more slender apical portion; the basal part provided with four or five very long plumose setæ, the apical part sparingly aculeate. Internal branches of the swimming feet two-jointed, outer branches three-jointed. Fifth pair of fect onc-branched, prehensile in the male, in the female rudimentary, consisting of a small basal joint, from which spring two slender, unequal setæ. Eye mobile, formed of several lenses.

The genus Acartia, though very imperfectly characterised and figured by Dana, was evidently meant to include the species belonging to Lilljeborg's more recently established genus Dias. Dana, however, does not appear to have seen the male of any of the four species described by him; and this accounts for his guarded statement as to the nongeniculation of the male antennæ. Indeed the males of the pelagic species of Acartic scem to be very scarce. I carcfully hunted for them in all the gatherings which have come under my notice, and only found one example,-a remarkable fact, seeing that in any gathering of the well-known European species, Acartia longiremis, males are quite commonly met with. The geniculation of the right anterior male antenna is rather indistinct, but the limb is considerably swollen for the insertion of flexor muscles; the posterior antenna has on the second joint of its larger branch a marginal series of rather long hairs. The marginal spines of the swimming feet differ from the common type in being continuous with the joints of the limb, and not articulated appendages. The terminal spines are narrow, sword-shaped, and finely serrated, and in length are more than equal to the whole outer branch. 
This genus, in the structure of its mouth apparatus, especially of the foot-jaws, shows a close relationship with Pontella, but the imperfect geniculation and absence of serrated plates in the anterior antennæ of the male, the peculiarly nodose and laxly setiferous character of those organs, the rudimentary form of the fifth pair of feet (especially in the female), and the small secondary branch of the posterior antenna, together with various minor differences in the spinous armature of the swimming feet, amply distinguish it from that genus.

From Corynura, a still more closely related genus, it is separated by the absence of serrated antennal plates, and by the structure of the maxillæ and tail.

All the members of the genus are usually colourless and almost transparent; and though not occurring so abundantly as many other Copepoda, are very widely distributed in all the great oceanic areas.

1. Acartia laxa, Dana (Pl. XXXII. figs. 1-11).

Acartia laxa, Dana, Crust. U. S. Expl. Exped., p. 1123, pl. lxxix. fig. 5, $a-c$.

Length, 1-18th of an inch (1.4 mm.). Female-Cephalothorax (fig. 1) elongated, very slightly tapered towards each extremity, obtusely pointed in front, truncated behind, posterior lateral angles produced into sharp, slender spines. Anterior antennæ (fig. 2) as long as the body, of nearly equal thickness throughout, bearing a few very long setæ, which are distributed somewhat as follows:- three or four near the base, on the third, fourth, and fifth joints; two or three in the middle, on the tenth and eleventh joints, and ten on the last five joints. The fifth pair of feet small (fig. 10), their two setæ about equal in length. The first segment of the abdomen (fig. 11) is equal in length to the remaining four, tumid, and armed with a slender spine on the posterior dorsal angle; the second segment is much produced downwards and backwards; caudal segments short, about as broad as long; setæ equal, spreading widely in a fan-shaped manner, and about as long as the abdomen.

Habitat.-Philippine Islands; between Arrou and Banda; Atlantic Ocean at several points between lat. $12^{\circ} 16^{\prime} \mathrm{S}$., and lat. $10^{\circ} 55^{\prime} \mathrm{N}$.

The presence of spines on the posterior lateral angles of the cephalothorax is the most tangible distinction between this and the following species; there is also a slight difference in the structure of the fifth pair of feet in the female (those of the male have not been seen), and in the anterior antennæ, which in Acartia laxa show no toothed marginal processes.

2. Acartia denticornis, n. sp. (Pl. XXXI. fig. 1, and Pl. XXXII. figs. 12-17).

(?) Acartia limpida, Dana, Crust. U.'S. Expl. Exped., p. 1119, pl. lxxix. fig. 2, a.b.

Length, 1-22nd of an inch (1.1 mm.). In general shape similar to Acartia laxa, except that the posterior angles of the cephalothorax are rounded off, and destitute of (ZOOL. CHALI, EXP.-PART XXIII-D1883.) 
spines. The setæ of the anterior antennæ are distributed pretty much as in Acartia laxa, but the joints, just above the origin of each seta, are angularly produced in a toothlike fashion. In the male (Pl. XXXII. fig. 12) the right anterior antenna is swollen below the middle, but is only indistinctly geniculated. The fifth foot in the male (fig. 15) is angularly bent, the penultimate joint bearing a stout subquadrate marginal process, the last forming a distorted, acuminate claw : in the female (fig. 16) the basal joint is short and broad, with truncated and angular apex, the two terminal setæ nearly equal in length, the inner one dilated at the base, the outer much more slender. The abdomen and tail setæ do not differ materially from those of Acartia laxa.

This is very similar to Dana's Acartia limpida, but some parts of the description cannot rightly apply to our species, as, for instance, "caudal stylets longer than twice their diameter," and "one seta of the posterior foot quite long and a little curved, the other less than a fourth as long"; moreover, the angular or toothed articulations of the anterior antennæ are not mentioned as characterising Acartia limpida.

Habitat.-Abundant in Hilo Harbour, Sandwich Islands (August 1875); one or two specimens noted in a gathering from the Philippine Islands, and (?) in the Atlantic, nortl of 'Tristan d'Acunha.

\section{Calanoides, n. gen.}

Cephalothorax six-jointed (in the male the first joint is barely visible), head united with the thorax; abdomen of the male five- of the female four-jointed. Anterior antennæ twenty-four-jointed, nearly alike in both sexes. Branches of the posterior antennæ nearly equal in length, inner branch with three small median joints. Mandiblepalp well developed, biting portion of the mandible well developed in the female, very feebly or altogether wanting in the male. Maxillæ and foot-jaws as in Calanus; the foot-jaws very small in the male. ${ }^{1}$ Five pairs of feet in both sexes; the inner and outer branches three-jointed throughout, except in the fifth pair of the male, which are very long, prehensile, and in which the inner branches are rudimentary.

In general appearance, in the structure of the antennæ, maxillæ, foot-jaws, and swimming feet, we have here an almost exact agreement with Calanus; but the absence of mandible proper in the male, and the conformation of the fifth pair of feet in the same sex, are characters which ally the genus to Euchcta, under which I was at one time disposed to place the single species known to me. Some of the most conspicuons characters of Euchceta are however wanting, as, for instance, the single long caudal seta, and the large doubly flexed posterior foot-jaws; while the three-jointed inner

1 In the two or three males which I dissected I was unable, except in one instance, to find any trace of the mandible proper; in one case, however, I observed a process, not unlike that figured by Giesbrecht as belonging to the male Lucullus acuspes, and which may possilbly represent the mandible. 
branches of the first and second swimming feet, and the presence of a fifth foot in the female, constitute other important points of distinction. But the most nearly allied genus appears to be one recently described by Dr. Giesbrecht, under the name Lucullus, in which, however, the anterior antenna of the male is only nineteen-jointed, and there are but four pairs of swimming feet in the female.

Calanoides patagoniensis, n. sp. (Pl. XXIII. figs. 1-10).

Length, 1-10th of an inch $(2.55 \mathrm{~mm})$. Rostrum bifid to the base, each branch very slender and produced into a long filament. Anterior antennæ about as long as the body, slender, sparingly seviferous, the joints rather constricted in the male. Branches of the mandible-palp (figs. 3, 4) two-jointed, short. Second foot-jaw of the male (fig. 7) bearing two reflexed, densely plumose setæ (as in Calanus). Swimming feet (fig. 8) slender, the marginal and terminal spines long and slender. Fifth pair of feet of the male (fig. 9) very long and slender, reaching considerably beyond the extremity of the abdomen, that of the left side the longest, the second joint of each side bearing at its apex a short rudimentary inner branch, which on the left side is one-jointed and almost obsolete, on the right longer and three-jointed: the main branch of each limb ends in a long spinelike seta. Abdomen in both sexes slender; caudal stylets about as long as broad; setæ subequal, the longest scarcely longer than the abdomen.

Habitat.-This species occurred in some abundance in a surface-net gathering in the South Pacific, lat. $46^{\circ} 53^{\prime}$ S., long. $75^{\circ} 11^{\prime}$ W. (Station 304).

\section{Atidius, ${ }^{1}$ n. gen.}

Cephalothorax composed of four segments; head and thorax coalescent; anterior antennæ twenty-four-jointed; posterior antennæ and mouth-organs (in the female at any rate) like those of Calanus. Four pairs of feet only in the female; five pairs in the male, the fifth pair rudimentary, though composed of two branches. Inner branch of the first pair one-jointed, of the second (indistinctly) two-jointed; of the third and fourth three-jointed. Abdomen of the male five- of the female four-jointed; tail setæ equai.

In general structure this is very closely similar to Calanus, the only important differences being found in the jointing of the inner branches of the swimming feet, the absence of a fifth pair in the female, and the rudimentary character of those organs in the male. The mandibles and foot-jaws are small, but I have not observed whether their characters materially differ in the two sexes. I have seen, I think, only one or two males, and my examination of them was made before I was aware of the great importance of sexual characters in these parts.

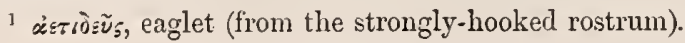


Etidius armatus, n. sp. (Pl. X. figs. 5-16).

Length, 1-12th of an inch $(2 \cdot 1 \mathrm{~mm}$.). Front of the head very broadly rounded, rostrum very stout, cleft to the base and produced in a continuous curve from the forehead. Last thoracic segment much produced, composed apparently of two fused somites, and forming at each side a backward-pointing spine, which is as long as the first abdominal segment. Anterior antennæ twenty-four-jointed (fig. 6), about as long as the body, the eighth joint longer than those which immediately precede and follow it; the joints from the fifteenth onwards are longer and more slender than the rest, except the last, which is very small; all the joints bear setæ, most of which are small, and none of excessive length. The two branches of the posterior antennæ (fig. 7) are nearly equal, and the inner branch has four very small median joints. The basal joint of the mandiblepalp (fig. 8) is large, the two branches small and indistinctly two- and three-jointed. Maxillæ and both pairs of foot-jaws (figs. 9, 10) small, and like those of Calanus. The inner branch of the second foot shows an indistinct division near the base (fig. 12) into two joints ; those of the third and fourth pairs are distinctly three-jointed (figs. 13, 14), but the first joint is in both cases very small. The fifth pair of the male (fig. 15) is almost obsolete, the outer branch composed of three, the inner of only one joint, and entirely destitute of setæ. Caudal segments about twice as long as broad, setæ nearly equal, and as long as the abdomen.

Habitat.--Indian Ocean in lat. $46^{\circ} 46^{\prime} \mathrm{S}$., long. $45^{\circ} 31^{\prime}$ E. (Station 146); in Torres Straits, off Port Jackson, at night; Chinese Sea, in lat. $17^{\circ} 54^{\prime} \mathrm{N}$., long. $117^{\circ} 14^{\prime} \mathrm{E}$. (Station 206) ; in lat. $32^{\circ} 24^{\prime}$ S., long. $13^{\circ} 5^{\prime}$ W. (Station 335); and in lat. $3^{\circ} 10^{\prime} \mathrm{N}$., long. $14^{\circ} 51^{\prime} \mathrm{W}$. (Station 348).

The strong curved rostrum, and the remarkably elongated, spiniform, posterior thoracic segment distinguish this species at a glance from any other with which I am acquainted.

\section{Drepanopus, ${ }^{\mathbf{1}}$ 11. gen.}

Head and thorax coalescent. Anterior antennæ twenty-three-, twenty-four-, or-twentyfive- jointed, nearly alike in both sexes. Posterior antennæ and mouth-organs as in Calanus. Inner branches of first pair of feet one-jointed; of the second pair one- or twojointed; of third and fourth pairs three-jointed. Fifth pair in the female rudimentary, composed of one branch only, in the male two-branched, prehensile, dissimilar on the two sides; inner branch rudimentary. Abdomen of the male five- of the female four-jointed.

The number of joints in the swimming feet here corresponds with that of the preceding genus, Etidius, but the presence of a fifth pair in the female, and the prehensile 
character of the same member in the male, preclude the possibility of referring both forms to the same genus. I therefore propose the name Drepanopus, which first suggested itself as being applicable to the fifth pair of feet of the female pectinatus.

\section{Drepanopus pectinatus, n. sp. (Pl. XXIV. figs. 1-11).}

Length, 1-9th of an inch $(2 \cdot 7 \mathrm{~mm}$.). Forehead rounded, rostrum short and slender; anterior antennæ twenty-three-jointed in the male, twenty-four-jointed in the female, as long as the cephalothorax, beset with short setæ, the proximal half in the male (fig. 3) bearing numerous stout club-shaped sensory appendages, the first and eighth joints in both sexes much longer than the rest. The inner branches of the second, third, and fourth feet have the first joint very small (figs. 8, 9), the marginal spines are sharp and slender, and the terminal spines are long, bayonet-shaped, and closely serrated. The fiftb pair of feet in the female (fig. 10) are simple, three-jointed, the first two joints short and tumid, the third joint slightly swollen at the base and produced into a long curved extremity, the distal half of which is pectinated on its outer margin. In the male (fig. 11) the fifth pair is prehensile, the right limb terminating in a long falcate claw; the left limb is much shorter, and the inner branches of both sides are almost obsolete, consisting only of a single minute joint.

Habitat.-Drepanopus pectinatus occurred very abundantly in three surface-net gatherings; the first, indeed, consisted entirely of this species, and was taken (approximately) in lat. $47^{\circ} \mathrm{S}$, long. $61^{\circ} \mathrm{E}$; the second and third were from Betsy Cove, Kerguelen Island, and from the open sea off the same place, so that the species, so far as our present knowledge goes, is confined to very narrow limits. Only one male was found, after looking over a very large number of specimens.

2. Drepanopus furcatus, n. sp. (Pl. IV. figs. 1, 2, and Pl. XXIV. figs. 12-15).

Length, 1-18th of an inch (1.4 mm.). Anterior antennæ as long as the cephalothorax, very similar to those of Drepanopus pectinatus, but the eighth joint is not larger than the rest, and the whole limb is less profusely setose. Mouth-organs and swimming feet also like those of Drepanopus pectinatus, except that the inner branch of the second foot (fig 12) is one-jointed, and the terminal spines (fig. 14) are shorter, stouter, and more finely serrated. The fifth pair in the female (fig. 15) is short and twojointed, the last joint forked at the apex. Male unknown.

Habitat.-This species, like the last, was found in three gatherings, but only sparingly. The three localities belong to totally distinct areas, and are as follows:- off Cape Howe, Australia, at night; in the tow-net, at a depth of 20 fathoms, in lat. $33^{\circ} 31^{\prime} \mathrm{S}$. ; long. $74^{\circ}$ 
$43^{\prime}$ W. (Station 299), this Station being off the west coast of South America, in the latitude of Valparaiso; and in lat. $5^{\circ} 28^{\prime}$ N., long. $14^{\circ} 38^{\prime}$ W. (Station 349), the last-named Station being in the Atlantic, a little south-west of Sierra Leone.

\section{Phyllopus, ${ }^{1}$ n. gen.}

Anterior antennæ twenty-four-jointed. Maxilla-palp rudimentary. Inner branches of all the swimming feet three-jointed (?) Fifth pair in the male (?) one-branched, the last joint leaf-like.

Phyllopus bidentatus, n. sp. (Pl. V. figs. 7-16).

Length, 1-7th of an inch $(3.6 \mathrm{~mm}$.). Anterior antennæ (fig. 7) having the joints from the eighth to the twelfth very short, only about half as long as broad, seventh, ninth, and fourteenth joints each bearing a single very long seta, the rest having short setæ, except the terminal one, which bears a lash of four setæ, two of them longer than the rest; the first joint is armed close to its origin with a long and slender curved spine, and all the shorter setæ of the limb are very straight and rigid, very obliquely truncate at the tips, the longer margin being produced into a short, extremely delicate filament, the whole having much the appearance of the nib of a quill pen; the last five joints are very much dilated at the apices,-more so than is represented in the figure. Mandibles (fig. 8) slender, divided at the apex into five long, slender teeth; palp having a large wedge-shaped base and two branches, one of which has two, the other four joints. The maxilla-palp (fig. 9) consists of a small ovate plate bearing six setæ, and a small two-jointed, setiferous digit. Anterior foot-jaw (fig. 10) stout, its marginal processes stout and triangular; posterior (fig. 11) small, the basal joint dilated. The last joint of the fifth foot (fig. 12) forms a leaf-like lamina, with deeply serrated margin, the innermost serration produced and larger than the rest; the penultimate joint bears on its inner margin a long, stout seta. Abdomen four-jointed, the first joint much stouter and longer than the rest (figs. 13, 14); caudal stylets about twice as long as broad; second tail-seta longer than the abdomen, the rest about half as long. Terminal spines of the swimming feet lancet-shaped (fig. 15), margin very finely pectinated. Rostrum (fig. 16) very short, bifid. Last thoracic segment (fig. 13) produced ventrally into a stout bidentate process.

Habitat.-Lat. $36^{\circ} 44^{\prime}$ S., long. $46^{\circ} 16^{\prime} \mathrm{W}$., down to 2650 fathoms (Station 325). One specimen only of this animal was seen, and in the anticipation of further specimens being available, was unfortunately only very imperfectly examined. The size of the first 
abdominal somite led me to suppose that the specimen described was a female; the characters of the anterior antenna and fifth feet, however, are rather those of the male.

\section{Temora, Baird.}

Calanus (in part), Leach, Dict. Sci. Nat.

Temora, Baird, Brit. Entomostraca, 1850; Claus, Die frei lebenden Copepoden, 1863 ; Boeck, Oversigt Norges Copepoder, 1864 ; Brady, Monog. Brit. Copep., 1878.

Diaptomus, Lubbock, Trans. Entom. Soc., 1856.

Body elongated; head distinct from the thorax; rostrum furcate. Fourth and fifth thoracic segments either completely coalescent, or their separation indicated merely by a furrow. Abdomen composed of four or five segments in the male; of three in the female. Anterior antennæ twenty-four- or twenty-five-jointed; that of the right side in the male geniculated. Mouth-organs as in Calanus. Inner branches of the swimming feet usually two-jointed. Fifth pair of feet in both sexes one-branched; in the male forming prehensile organs.

The type of this genus is Temora longicaudata (Lubbock); a species in which the inner branches of the swimming feet are all two-jointed, except, perhaps, in the case of the first foot, where the division into two joints is often only indistinctly visible. For the most part the two joints are perfectly distinct, even in the first foot, and they are so figured by Dr. Baird. Claus, however, has made it part of his definition of the genus Temorc that the inner branch of the first foot is single-jointed, while those of the second, third, and fourth pairs are two-jointed. Though this is correct as to one of the European species (Temora velox), it is not so, as regards the first foot, with Temora longicaudata, and in the case of Temora dubia, now to be described, the discrepancy extends to the second and third feet of the female, where the inner branches are only one-jointed, while, on the other hand, the inner branch of the first foot is bi-articulate.

From Calanus and Pseudocalanus this genus is readily distinguished by the structure of the fifth pair of feet, and anterior antennæ of the male. From Isias and Diaptomus it is separated by differences in all five pairs of feet, though it must be admitted to be doubtful how far these generic distinctions may remain tenable as our knowledge of allied forms increases.

1. Temora dubia (Lubbock), (Pl. XXV figs. 1-17).

Diaptomus dubius, Lubbock, On some Entomostraca collected by Dr. Sutherland in the Atlantic Ocean, Trans. Entom. Soc., vol. iv. N. S., 1856, p. 21, pl. ii. figs. 1-7.

Length, 1-13th of an inch (1.95 mm.). Cephalothorax very robust, about half as broad as long, rounded in front, subtruncate behind, the posterior lateral angles produced into long spinous processes (fig. 16). Anterior antennæ of the female (fig. 3) about as long as the cephalothorax, twenty-four-jointed, the joints not varying greatly in length, 
and uniformly clothed with short slender setæ; in the male (fig. 2) the right anterior antenna is swollen in the middle, and geniculated, the joints before and behind the hinge being armed with finely serrated plates. The inner branch of the posterior antenna (fig. 4) is five-jointed, the three median joints very small. The outer branches of the first four pairs of feet are, as a rule, three-jointed, but in the female those of the second, third, and fourtl pairs are only two-jointed, and in the male that of the second pair is occasionally two-jointed; the inner branches are all two-jointed, except in the second and third feet of the female, where they are one-jointed (figs. 9, 10, 11). The terminal spines of the feet (fig. 15) are rather short and stout, their marginal teeth generally broad and distant. The fifth foot of the right side in the male (figs. 12, 13) is broad, its first joint produced laterally into a long twisted immobile claw-like finger, the last joint blunt, irregularly oval, and bearing a few small marginal setæ; the foot of the left side is simple, slender, and ends in a slender flexuous claw. Fifth pair in the female (fig. 14) simple, three-jointed, the last joint bearing one small marginal, and three unequal terminal, spines. Abdomen slender, in the female three-jointed, in the male (figs. 16, 17) five-jointed; caudal stylets very long and slender, about equal in length to the abdomen proper, and ten or twelve times as long as broad, bearing one long seta on the middle of the outer margin and four nearly equal apical setæ, which are about as long as the caudal stylet. The stylets themselves are frequently unequal in size and more or less distorted.

This species often occurs in great numbers, and seems peculiarly liable to "sports;" the caudal segments of the two sides are rarely quite alike, and are often very considerably distorted, and the build of the swimming feet is likewise extremely variable. The limb of one side may have a different number of joints from its fellow of the opposite side, so that the foregoing statement as to the normal arrangement of the joints must be taken as applying only to what appears to be the commonest condition, but subject, nevertheless, to very frequent variation.

Habitat.-Off Cape Howe, Australia ; off Port Jackson ; off Kandavu, Fiji ; between Api and Cape York ; in many localities off the Philippine Islands ; lat. $37^{\circ} 3^{\prime}$ S., long. $44^{\circ}$ $17^{\prime}$ W. (Station 326); off Zamboanga; in the Arafura Sea; off the Ki Islands; in several Atlantic gatherings between lat. $3^{\circ} \mathrm{N}$. and lat. $20^{\circ} \mathrm{N}$--very abundant in many of those gatherings.

\section{Temora armata, Claus.}

Temora armata, Clans, Die frei lebenden Copepoden, p. 195, Pl. xxxiv. figs, 12, 13.

A single specimen, agreeing closely with Dr. Claus's description of this species, but apparently immature, was taken off the west coast of Africa, in lat. $10^{\circ} 55^{\prime} \mathrm{N}$., long. $17^{\circ}$ $46^{\prime} \mathrm{W}$. One pair of swimming feet (fourth ?) has both branches three-jointed, the rest 
hare both two-jointed. The general characters are those of Temora; rostrum and caudal stylets as figured by Claus.

\author{
Centropages, Kröyer. \\ Centropages, Kröyer, Nat. Tidskr., 1849. \\ , Boeck, Oversigt Norges Copepoder, 1864. \\ " Brady, Monog. Brit. Copepoda, 1878. \\ Catopia, Dana, Proc. Amer. Acad. Sci., 1849. \\ Calanopia, Dana (in part), Crust. U. S. Expl. Exped., 1852. \\ Ichthyophorba, Lilljeborg, De Crustaceis ex. ord. trib., 1853. \\ „ . Claus, Die frei lebenden Copepoden, 1863.
}

Body elongated; head distinct from the thorax, produced into a cloven rostrum, and more or less distinctly divided by a transverse groove into two segments. Anterior antennæ twenty-four-jointed, that of the right side in the male geniculated and prehensile. Mandibles, maxillæ, and foot-jaws similar to those of Calcuns, except that the setæ of the anterior foot-jaws are beset with strong marginal hairs as in Pontella. The five pairs of swimming feet have both hranches three-jointed, except the outer branch of the left fifth foot in the male, which is only two-jointed, while on the right side the outer branch, though three-jointed, forms a doubly-clawed prehensile organ. Eye median and mobile, of moderate size.

From Pontella this genus is separated by the single eye, hy the Calanoid form of the posterior foot-jaw, the three-jointed inner branches of the swimming feet, and by the peculiar structure of the fifth pair of feet in both sexes. From Diaptomus, Temora, and other nearly allied genera, the characters of the swimming feet, especially of the fifth pair, form a sufficient distinction, while from Candace it is further separated by the structure of the mouth-organs, more particularly of the mandibles and maxillæ.

The names Catopia and Calanopia were proposed by Dana, the one as a genus, the other as a sub-genus, to include certain species closely allied to Pontella. The characters relied upon do not, however, appear to be very important, or very serviceable as landmarks of classification, the two species assigned by Prof. Dana to Calanopia (Calanopia elliptica and Calanopia brachiata), belonging, in my view, to two distinct genera. The name Centropages, used by Kröyer in 1849, has precedence, of course, over the more lately published Calanopia and Ichthyophorba, while Catopia, though dating from the same year as Centropages, has not obtained the same currency, and, moreover, has scarcely been defined with sufficient precision.

Of this genus three European species have been described. Centropages typicus, Kröyer, Centropages hamatus, Lilljeborg, and Centropages violaceus, Claus; the last of which is by far the commonest representative of the group in the Challenger collection, occurring in at least ten of the surface-net gatherings. But though this one form is very

(ZOOL. CHALL. EXP.-PART XXIII.-1883.) 
widely distributed, it does not appear that the genus is rieh in speeies; only two others have been found amongst the Challenger eaptures, and these oeeurred but sparingly.

\section{Centropages brachiatus, Dana (Pl. XXVI. figs. 1-7).}

Calanopia brachiata, Dana, Crust. U. S. Expl. Exped., p. 1133, pl. lxxix. fig. 7, a.b.

Length, 8-100ths of an ineh $(4 \cdot 4 \mathrm{~mm}$.). Cephalothorax elongated, slightly constrieted at the points of junetion of the somites, posterior angles produeed into strong hook-like spines; anterior antennæ slender and about equal in length to the body of the animal, the first two joints somewhat larger and stouter than those immediately following, those from the third to the eleventh very small, none of them being mueh longer than broad, the next three eonsiderably longer; the fifteenth to the nineteenth are the longest of all, being about four times as long as broad, the apieal joints somewhat shorter; the entire limb beset with rather short, slender setro the first, seeond, and fifth joints each bear on the outer margin a short, stout spine, and several of the lower joints, from about the seventh to the twelfth, have one or more aborted spines (fig. 2). The right anterior antenna of the male (fig. 3), in addition to the spines already mentioned, has welldeveloped spines on the tenth and eleventh joints; the twelfth, thirteenth, and fourteenth are greatly enlarged, the thirteenth and fourteenth having eaeh a very strong spine; the fifteenth, sixteenth, and seventeenth joints are more slender, but about twiee as long as the preceding, and are armed on the inner aspect with finely serrated plates, the hinge being situated between the sixteenth and seventeenth; the eighteenth joint is of equal size, but has no serrated plate; these four joints represent by eoaleseenee seven joints of the normal antenna (15-21). The outer braneh of the fifth foot in the female has the middle joint very short, and produeed internally into a very long and strong spine, the margins of which are smooth. The outer braneh of the right fifth foot in the male (fig. 6) forms a powerful, doubly-elawed, prehensile organ, the upper internal angle of the middle joint produeed into an extremely long hooked elaw, whieh opposes at its extremity the elaw-like termination of the last joint; the lower outer angle also of the middle joint forms a long claw-like process, which is twisted to the inside so as to have the same direetion as the upper elaw; the foot of the left side has the outer branch two-jointed, equal in length to the inner braneh, the last joint truneated, and bearing only three or four setæ at the apex. The first segment of the female abdomen bas on eaeh lateral margin two slender curved spines. The caudal segments are about twiee as long as broad, and likewise twiee as long as the last abdominal segment. Tail setæ subequal, short, the longest eonsiderably shorter than the length of the abdomen, the four external setæ in the female, but not in the male, are conspicuously dilated towards the base. Eye small, composed of two closely approximated oeelli.

Habitat.-Several speeimens of this species oecurred in tow-net gatherings off 
Talparaiso (Station 298), November 18, 1875, and from the west coast of Patagonia (Station 304), December 31, 1875. Prof. Dana's type specimens were from the Lagulhas Bank, near the Cape of Good Hope and from the South Pacific, in lat. $42^{\circ}$ to $36^{\circ}$.

Though Dana's description does not quite accurately apply to the Challenger specimens, more especially as to the spinous armature of the antennæ (no notice being taken of the small spines near the base), I can scarcely doubt that it is meant to refer to the species here under review; the differences, at any rate, are not so great as to warrant my proposing a fresh specific name. It must be noted, however, that the size assigned by Prof. Dana to his species (1-12th of an inch) is only about half that of our specimens.

\section{Centropages furcatus, Dana (Pl. XXVIII. figs. 1-11).}

Catopia furcata, Dana, Crust. U. S. Expl. Exped., p. 1173, pl. lxxix. fig. 1, a.-d.

Length, 8-100ths of an inch (2 mm.). Body elongated, cylindrical, posterior angles of the cephalothorax produced each into two spines (figs. 1, 2), the outer spine much the longer of the two, and separated from the inner by a deep curve. Anterior antennæ spined on the first, second, and fifth joints, as in Centropages brachiatus, and agreeing generally with that species in length of joints; the right antenna of the male, however (figs. 3,4), is more feebly serrated in the geniculating portion, and has no spines except on the basal joints, the median joints are only slightly enlarged. The fifth right foot of the male is very similar to that of Centropages brachiatus, but the second joint has only one uncinate process, and the last joint has one internal and two external marginal spines (fig. 8). The fifth foot of the female (fig. 9) is also like Centropages brachiatus, except that the spine of the median joint is slightly serrated, and projects downwards instead of at a right angle to the limb. The first segment of the femcle abdomen has no hooks, but is very tumid below. Caudal segments narrow, not divergent, about five times as long as broad. Eyes coalescent, single, indistinctly three-lobed.

Habitat.-Centropages furcatus was taken in the tow-net, off Port Jackson; in the Arafura Sea, September 13, 1874 ; and near the island of Mindanao, February 4, 1875. Prof. Dana's specimens were from the Straits of Banca.

\section{Centropages violaceus, Claus (Pl. XXVII. figs. 1-14). Ichthyophorba violacea, Claus, Die frei lebenden Copepoden, p. 199, pl. xxxv. figs. 13, 14 .}

Length, 1-11th of an inch $(2.3 \mathrm{~mm}$.). Cephalothorax elongated, cylindrical, narrowed towards the front and behind, posterior angles rounded off, internodes slightly constricted. Anterior antennæ (fig. 4) very slender, longer than the animal, gradually tapering from base to apex, twenty-four-jointed, fourteenth to nineteenth joints the longest, entirely destitute of spines, but clothed, especially towards the base, with slender setæ. The right anterior antenna of the male (figs. 2, 3) is but 
slightly dilated in the middle; the joints on each side of the hinge bear delicately serrated marginal plates, and at the base of each plate there is a small spine. The terminal spines of the swimming feet are very slender, scarcely stouter than the marginal setæ. The outer branch of the fifth foot in the female (fig. 11) has its inner apical angle produced into a stout spine, which does not reach more than half the length of the third joint. In the male the fifth foot of the right side (fig. 12) is prehensile, the middle joint of the outer branch forming a robust, blunt, claw-like process, while the last joint bears at the apex a long, slender, doubly-curved, or S-shaped claw; the left foot has the last joint of its outer branch (fig. 13) distorted at the extremity, where it bears three short spine-like setæ. The abdomen in the male is elongated, but in the female short and stout; the caudal segments are flattened, slightly divergent, and scarcely twice as long as broad; setæ six, subequal, stout, shorter than the abdomen; in the female (fig. 14) the place of the second seta-counting from the outside-is usually occupied by a stout club-shaped appendage.

Habitat.-Off Cape Howe, Australia; off the Philippine Islands; Pacific, east of Japan, lat. $30^{\circ} 22^{\prime}$ N., long. $154^{\circ} 56^{\prime} \mathrm{W}$. (Station 256) ; South Pacific, October 18, 1875 (near Station 287) ; Atlantic, lat. $40^{\circ} 3^{\prime}$ S., long. $132^{\circ} 58^{\prime}$ W. (Station 288); lat. $42^{\circ} 43^{\prime}$ S., long. $82^{\circ} 11^{\prime} \mathrm{W}$. (Station 302) ; lat. $37^{\circ} 3^{\prime}$ S., long. $44^{\circ} 17^{\prime}$ W. (Station 326); lat. $37^{\circ}$ $31^{\prime}$ S., long. $36^{\circ} 7^{\prime} \mathrm{W}$. (Station 329); lat. $9^{\circ} 43^{\prime}$ S., long. $13^{\circ} 51^{\prime} \mathrm{W}$. (Station 342 ); North Atlantic, lat. $26^{\circ} 21^{\prime} \mathrm{N}$., long. $36^{\circ} 6^{\prime} \mathrm{W}$. In many of these places the species occurred in considerable abundance, showing a very extensive range of distribution, from the Mediterranean on the north to the coast of Patagonia southward, and to Japan, the Philippine Islands, and Australia in the east.

Dr. Claus describes his Ichthyophorba violacea as being violet-coloured with red spots. Such a description would perhaps not inaptly apply to the Challenger specimens when fresh, and I am the more inclined to suppose so, as the spirit specimens may be very readily separated from the bulk of the gatherings in which they occur by the presence of a cloudy purplish-brown patch on the body of each. This very probably represents the more diffused colouring of the living animal after being acted on by preservative fluid. The other points of Dr. Claus' description accord perfectly with our specimens, except as to the left fifth foot of the male, in which I find three terminal setæ instead of only two. The peculiar setose armature of the caudal segments in the female is not noticed by Dr. Claus.

\section{Calanopia, Dana.}

Calanopia, Dana, in part, 1852.

Anterior antennæ eighteen-jointed, that of the right side in the male geniculated, provided with two denticulated plates, and somewhat angulated at the flexures. Mouth- 
organs generally as in Pontella; apical portion of the posterior foot-jaw six-jointed. Inner branches of the swimming feet two-jointed. Fifth pair of feet in both sexes consisting of one branch only. Abdomen of the female two, of the male five-jointed. Rostrum cloven; eyes two, small, closely approximated, near the base of the rostrum.

The smaller number of joints in the anterior antenna, and the unbranched character of the fifth pair of feet in both sexes are perhaps characters sufficiently important to warrant the retention of the generic name originally applied by Dana to this species, though on different grounds. Dana describes two sets of eyes, an inferior and superior, both very minute. In my spirit specimens I have been able to detect only the superior.

1. Calanopia elliptica, Dana (Pl. XXXIV. figs. 1-9).

Calanopia elliptica, Dana, Crust. U. S. Expl. Exped., p. 1132, pl. lxxix. fig. 6, a.b.

Length, 1-14th of an inch (2 mm.). Cephalothorax elongated, ovate, tapering and rounded off in front, posterior lateral angles sharply spined; anterior antennæ (fig. 2) slender, about as long as the cephalothorax, eighteen-jointed, third and sixth joints extremely short, tenth, eleventh, twelfth, and thirteenth long and slender; sparingly setose towards the apex, more densely on the proximal half; the principal serrated plate placed on the proximal side of the hinge (fourteenth joint); armature consisting of very fine, closely-set setæ (fig. 4). The upper half of the fifteenth joint is also very faintly pectinated, the serrations not being visible except with a high power of the microscope. Last joint of the right fifth foot in the male (fig. 7) stout and claw-like, its basal portion expanded, concave margin very irregularly rugose and dentated; terminal joint on the left side simple, cylindrical, marginally setose near the apex, bearing two apical and three lateral spines, the outer angle of the penultimate joint produced into a strong spine. Fifth pair of feet in the femcle simple, elongated, cylindrical, penultimate joint bearing a strong apical spine, last joint with three ciliated spines. The second segment of the male abdomen is produced on the right side into an acute angle, the last joint is extremely short; the caudal stylets about thrice as long as broad and more than equal in length to the last two abdominal segments; the two central tail setæ much longer than the rest,- -about equal to the length of the abdomen.

Habitat.-Off Sibago Island, Zebu Harbour, and at other points off the Philippine Islands. Mr. Dana's specimens were taken in the Straits of Banca, east of Sumatra.

\section{Pontellopsis, n. gen.}

Head distinctly separated from thorax; abdomen of female two-jointed (?), and having a pouch-like protuberance on the left side. Anterior antennæ eighteen-jointed; 
primary branch of posterior antenna three-jointed; secondary branch small, indistinctly four-jointed; mandible-palp composed of a moderately large basal joint, and two small branches composed of several joints ; maxillæ and foot-jaws nearly as in Pontella. Inner branch of first swimming foot three-jointed, those of the following pairs two-jointed; fifth pair of feet two-branched. Eyes coalescent at base of rostrum.

This genus differs from Calanopia in the structure of the posterior antennæ, mandible-palp, first and fifth pairs of fect, and in the peculiar outgrowth of the abdomen. From Pontella it is separated by the less numcrously jointed anterior antennæ, and especially by the characters of the posterior antennæ and mandible-palp. But no males having been observed, the generic characters here given must be taken as merely provisional.

The two species described by Dana as Pontella pulchra and Pontella emerita, would appear to be nearly allied to that here noticed; but without fuller details it is impossible to say whether they really belong to the proposed new genus.

1. Pontellopsis villosa, n. sp. (Pl. XXXV. figs. 14-20, and PI. XXXIV. figs. 10-13).

Length, 1-8th of an inch (3 mm.). Female.-Cephalothorax elongated, cylindrical, posterior angles produced into long, almost straight spines. Anterior antennæ (Pl. XXXV. fig. 15) eighteen-jointed, shorter than the cephalothorax, seventh and eighth joints coalescent and slightly swollen at the apex, all the joints bearing apical and marginal setæ of modcrate length. Primary branch of the posterior antenna (Pl. XXXIV. fig. 10) three-jointed (sometimes indistinctly so); secondary branch very short, fourjointed, the two apical joints very small. The mandible is stoutly toothed and clothed with fine hairs toward the apex; palp two-branched, one branch composed of two, the other of five joints. Inner branch of the first swimming foot (Pl. XXXV. fig. 17) threejointed, all the marginal spines of its outer branch very long and slender. The second, third, and fourth feet have two-jointed inner branches (fig. 18), the marginal spines of the outer branches ciliated, those of the first and second joints very long. Fifth pair of fcet (female) two-branched (fig. 19), cach branch consisting of a single joint, the inner very short, with furcate apex, the outer very much longer, bcaring sereral spine-like setæ, three at the apex and two or three on the sides. Abdomen (fig. 20) two-jointed (?), produced at the distal extremity of the left side into a curious cushion-like villous protuberance, with a few tcrminal spines; caudal segments about twice as long as broad, setæ subequal ; integument of the abdomen clothed with short hairs.

Habitat.-Lat. $30^{\circ} 22^{\prime}$ N., long. $154^{\circ} 56^{\prime} \mathrm{W}$. (Station 256); Atlantic between lats. $37^{\circ}$ and $38^{\circ} \mathrm{S}$., and long. $45^{\circ}$ to $48^{\circ} \mathrm{W}$.

Three specimens only were found in these gatherings, all femalcs. 
Sub-family 2. Pontelline, Dana.

In this sub-family there are two or more paired lateral sessile eyes, in addition to a large median eye, which is situated near the base of the rostrum, and is more or less prominent, and covered by an excessively convex lens.

\section{Pontella, Dana.}

Pontia, Milne-Edwards, Hist. Nat. des Crust., 1828.1

Pontella, Dana, Amer. Journ. Sci., 1846.

" Claus, Die frei lebenden Copepoden, 1863.

" Brady, British Copepoda, 1878.

Pontellina, Claus (in part), Die frei lebenden Copepoden, 1863.

Monops, Lubbock, Ann. and Mag. Nat. Hist., 1853.

Labidocera (Iva, Ivella), idem, ibidem, 1853.

Head distinct from the thorax, fourth and fifth thoracic segments coalescent. Abdomen of the male five- (sometimes three- or four-) of the female two- or threejointed. Anterior antennæ twenty-one to twenty-four-jointed; sixth and seventh joints either coalescent or distinct; right antenna of the male more or less swollen in the middle from the thirteenth to the sixteenth, and hinged (usually) between the nineteenth and twentieth joints; seventeenth, eighteenth, and nineteenth united into one long joint which bears a serrated plate on its inner margin, twentieth and twenty-first joints also coalescent and serrated. Posterior antennæ bearing a large secondary branch. Mandibles well-developed, strongly toothed at the extremity, and bearing a palp composed of a large basal joint and two short branches. Maxillæ well-developed, composed of a broad, preliensile, or chewing portion, and a large three-lobed palp. Anterior foot-jaw robust, with strongly plumose setæ; basal portion of the posterior foot-jaw stout, divided at the apex of the inner margin into three (often indistinct) digits, which bear about six strongly plumose setæ; apical portion much more slender, elongated, four-jointed, setiferous. ${ }^{2}$ Inner branches of all the swimming feet (except occasionally the first) twojointed. Fifth pair of feet in the male adapted for elasping, that of the right side usually larger than the left. Lower eye stalked; two upper eyes often coalescent, composed of numerous refracting bodies, witlı two large, simple, more or less closely approximated lenses.

Dana (1852) has proposed to divide the genus Pontella into three sub-genera, characterised as follows :--

"1. Calanopia.--Including the Calanoid Pontellæ, in which the anterior antennæ are situated as in Calanus, with the tips not anterior to the line of the front; the anterior

1 This generic name, though prior in date, is discarded, having been already used by Fabricius for a genus of Lepidoptera.

2 The details of the mouth-organs, \&c., given in Pl. XXXIX. (Pontella kröyeri) represent the typical generic structure. 
branch of the posterior antennæ have but three setæ at the apex; the inferior eyes are quite small. This sub-genus may include some species referred to Hemicalanus.

“2. Pontellina.-Antennæ of second pair having five setæ at the apex of the anterior or smaller branch; head either side unarmed.

"3. Pontella.-Antennæ as in the last; head either side armed with a reversed spine. The Pontia atlantica of Edwards is of this kind. In this division the second of the caudal setæ is considerably longer (one-fourth at least) than the others (in most, if not all cases), which is not true of the preceding sub-genus Pontellina."

Again, Sir John Lubbock ${ }^{1}$ has proposed two new genera-Labidocera and Monopswith three sub-genera, Labidocera, Ivella, and Iva. The generic and sub-generic definitions are as follows:-

"Labidocera.-Rostrum furcatum; antenna antica maris dextra geniculans, tumida, lamellis lobulisve dentatis instructa. Oculi superiores duo. Oculi inferiores nulli? Cephalothorax 7-articulatus. Pes posticus maris dexter, prehensilis. Abdomen maris 4-articulatum, feminæ 2-articulatum.

"Sub-genera :-1. Labidocera.-Antenna antica maris dextra duabus serratis lamellis instructa. Spina prehensilis, parva, rigido crini similis. Pes thoracicus quintus sinister, parvus, ramum internum 2-articulatum, ad apicem annulatum gerens. 2. Ivella.Anterna antica maris dextra tribus dentatis lobulis instructa. Spina prehensilis, magna. Pes thoracicus quintus sinister, magnus, fortis, ad apicem acutus et corneus, ramum internum non gerens. 3. Iva.-Antenna antica maris dextra quatuor dentatis lamellis instructa, tumidissima. Spina prehensilis, maxima, annulata. Pes thoracicus quintus sinister, magnus, ad apicem tumidus, papillosus.

“Monops.-Rostrum furcatum. Antenna antica maris dextra geniculans, tumida. Oculi superiores nulli. Oculus inferior unicus. Pes posticus maris dexter crassus prehensilis."

The characters, however, upon which these divisions are based, though useful as affording specific distinctions, utterly break down when applied to larger groups. It has been already shown that Dana's two species of Calanopia belong really to distinct genera, and would scarcely have been brought together if the characters of the mouthorgans and feet, as well as the eyes and antennæ, had been taken into account. ${ }^{2}$ For the same reason, Sir John Lubbock's genera and sub-genera appear to me quite untenable. The restriction of the generic term Pontellina as proposed by Dr. Claus, to species having a rostral lens, lateral upper eyes, lateral spines on the head, and a six-jointed apex to the posterior foot-jaw, will, I suspect, also be found impracticable; at any rate if the subordinate character of a three-jointed inner branch to the first foot is to be taken in

1 Ann. and Mag. Nat. Hist., March, August, and September 1853.

${ }^{2}$ It will be seen that though I adopt this term Calanopia for a genus of which Calanopia elliptisa, Dana, is the type, I depend for its diagnosis on characters entirely distinct from those originally proposed. 
conjunction with the rest. Amongst the Challenger species it will be seen that the sixjointed apex occurs not infrequently with a two-jointed inner branch of the first foot, though, as regards the character of the eyes, I am not able to speak certainly, owing to the action of spirit on the specimens.

* Head without lateral spines; apex of posterior foot-jaw four-jointed.

\section{Pontella acuta, Dana (Pl. XXXVI. figs. 1-12).}

Pontellina acuta, Dana, Crust. U. S. Expl. Exped., p. 1150, pl. lxxx. fig. 12, a.-c.

Length, 1-6th of an inch $(4.2 \mathrm{~mm}$.). Cephalothorax stout, cylindrical, posterior angles strongly produced and spined, that of the right side in the male twisted (fig. 10); head transversely sulcate in the middle, rostrum trifid, the two lateral segments larger and curved slightly downwards, the central standing straight up, so as to appear single when seen in front or behind. Anterior antennæ (fig. 2) twenty-one-jointed, rather longer than the cephalothorax, densely setose towards the base; that of the right side (fig. 3) in the male has the central joints considerably swollen; the two denticulated plates produced at the extremities, teeth short and stout (figs. 4, 5), those of the upper plate acute, of the lower squared at the apices. Inner branches of all the swimming feet two-jointed. The terminal spines of the swimming feet are somewhat dagger-shaped, and have a wide pellucid outer border, which is very minutely pectinated ; the marginal spines short, lancet-shaped, with pellucid, finely pectinated edges. Fifth pair of feet in the female two-branched (fig. 9), both branches one-jointed, the outer twice as long as the inner, with three strong spines on the outer margin, and three at the apex; inner branch divided apically into two teeth. The fifth feet in the male (fig. 8) are unbranched, that of the right side having the first two joints long and simple, the following joint fan-shaped, and ending in a large pear-shaped claw; the three joints of the left side are nearly simple, the third bearing three or four curved apical claws, and a stouter one on the outer margin; the inner margin is fringed with delicate hairs. Abdomen of the female three-jointed, of moderate length, not quite half as long as the cephalothorax, last joint about equal in length to the caudal stylets; last joint of the male abdomen scarcely half as long as the stylets. The first abdominal somite bears at the apex of the right margin two spine-like processes, one of which in the female is very large (fig. 11). Caudal segments about twice as long as broad; setre subequal, shorter than the abdomen. In the female the basal halves of the second, third, and fourth setæe (counting from the outside) are much dilated (fig. 12), the dilated portion of the second gradually tapering away, those of the third and fourth ending abruptly; all the setro in their slender portions are densely plumose; those of the male are all spathulate towards the base, but not abruptly dilated. as in the female. The anterior eyes are (ZOOL. CHALL. EXP.—PART XXIII.-1883.) 
situated near the base of the rostrum; in the female they are of moderate size and distant; in the male large and closely approximated.

Habitat.-Off Port Jackson, Australia ; off Sibago Island and in other places amongst the Philippine Islands, and in the Arafura Sea, September 13, 1874.

Though Prof. Dana passes without notice the peculiar tail setæ and remarkable trifid beak of this species, many of the other characters figured and described by him as pertaining to Pontellina acuta (as, for instance, the fifth foot of the male and the twenty-one- and twenty-two-jointed antennæ) are so peculiar and so exactly similar to those of the specimens now under consideration, that it seems almost certain that the species referred to in both cases are the same. The two lateral spines of the rostrum, though large, may easily be overlooked in certain positions of the animal. Dana's measurement, 1-10th of an inch, is much less than mine, but a similar discrepancy occurs in many other cases. Dana's specimens, like ours, were obtained in the Eastern Seas :"East Indies, off the south-east end of Mindoro, and in the China Sea." It should be noted that, owing to the position in which the animal is drawn, the eyes in fig. 1 do not appear so far distant as they ought to do.

\section{Pontella detruncata, Dana (Pl. XXVI. figs. 8-15; Pl. XLV. fig. 20). \\ Pontellina detruncata, Dana, Crustacea, U. S. Expl. Exped., p. 1143, pl. 1xxx. fig. 7, a.-i.}

Length, 1-șth of an inch (3 mm.). Head subtruncated and obscurely angular in front, posterior angles of the cephalothorax rounded off or angular, not produced into long spines; rostrum furcate, of moderate length. Anterior antennæ twenty-twojointed, densely clothed externally with long setæ towards the base, and on the inner aspect in the same region fringed with numerous delicate hairs (fig. 8); the right anterior antenna of the male (figs. 9, 10, 11) is much swollen in the middle, and bears three denticulated plates, the uppermost and lowest having produced, rounded, and thickened extremities; the denticulations of all three plates differ somewhat in character, those of the upper plate being slender and recurved and graduated in length from the middle to each extremity; in the middle plate the teeth are straight and sharp, each set upon a distinct, enlarged base, while those of the last plate are short, stout, and triangular. Inner branches of the swimming feet all two-jointed, spines as in the preceding species, but rather more slender. Fifth pair of feet in the male (fig. 13) onebranched; first two joints of the right limb simple, third joint produced at the basal angle into a stout, claw-like prominence, and armed at the apex with a long, slender, curved claw, which bears three slender marginal setæ; the left limb is simple, but is provided at the apex with four slender, curved, claw-like appendages, and has its margin finely setose. Fifth pair of the female (fig. 12) almost rudimentary, cylindrical, slightly denticulated at the apices; the penultimate joint bears an internal branch composed of 
one minute joint. The last joint of the abdomen is in both sexes (figs. 14, 15) very small, shorter than the caudal stylets, which are about as broad as long; terminal setæ subequal, as long as the abdomen, and alike in both sexes. Eyes three, the upper pair large and closely approximated.

Habitat.-Pacific, 400 miles south of Hawaii, and north of the Sandwich Islands, moderately abundant; Atlantic off Buenos Ayres; and off St. Vincent, Cape Verde.

The type specimens of this species were taken in various parts of the Pacific, and are evidently identical with those here described. Dana's figures of the female fifth foot, however, do not agree with mine, nor, as usual, do our measurements coincide, the length of the types being given as 1-12th to 1-16th of an inch. The colour is said by Dana to be, like most of the Pontellce, bluish; but this I have no means of confirming, spirit specimens only having come under my notice.

3. Pontella acutifrons, Dana (Pl. XXXV. figs. 1-13).

Pontellina acutifions, Dana, Crustacea, U. S. Expl. Exped., p. 1149, pl. Ixxx. fig. 11, a.-h. (1852).

Pontella bairdii, Lubbock, Ann. and Mag. Nat. Hist., second series (1853), vol. xii., p. 117, pl.v. figs. 1-6.

? Pontia edwartsii, Kröyer, Nat. Hist. Tidskr., 2 Række, Bind ii. (1846-9), p. 599, pl. vi. figs. 8-11.

Length, 1-6th of an inch $(4 \cdot 2 \mathrm{~mm}$.). Cephalothorax elongated, cylindrical, tapering towards each extremity, posterior lateral angles produced and acutely angular, head pointed in the middle, transversely sulcate, rostrum of moderate length and furcate. Anterior antennæ as long as the cephalothorax (fig. 3), twenty-four-jointed, third to twelfth joints densely clothed with long hairs on the outer and finely setose on the inner margin ; right antenna of the male (figs. 4-7) moderately swollen in the middle, two denticulated plates terminating above and below in very long free extremitics; the upper of those curved processes bites against a small tooth attached to the base of the preceding antennal joint (fig. 6) ; inner branches of all the swimming feet two-jointed; marginal spines of the outer branches lancet-shaped and duplicated (fig. 8), terminal spines as in Pontella detruncata. Fifth pair of feet in the male (fig. 10) having the third joint of the right side irregularly quadrate, and produced at the base so as to form an immovable claw, bearing at the apex a stout subpyriform claw ; the basal joint of the left side has a peculiar twisted and laciniated appendage (penis?); the terminal joint finely setose and bearing two small apical claws. Fifth paix of feet in the femcle (fig. 9) simple, last joint elongated and trifid at the apex, penultimate joint bearing a rudimentary one-jointed internal branch. The first segment of the female abdomen (fig. 12) is usually very tumid, the caudal segments not much longer than broad, and often much projected laterally (perhaps a distortion), that of the right side bearing two spines on 
its outer margin, and having the three outer setæ dilated and spathulate at the bases. The setæ are all nearly equal in length; those of the left segment are not spathulate, nor are any of those of the male animal. The upper eyes are closely approximated, larger in the male than in the female.

Habitat.-Off Port Jackson, Australia; abundantly between Api and Cape York; Philippine Islands (February 6, 1875) ; abundantly in the Pacific, north of the Sandwich Islands; in several gatherings from the North Atlantic near the Cape de Verde Islands, and near the $\mathrm{Ki}$ Islands, Australasia. This appears to be one of the commonest and most widely-distributed of the Pontella, and there can be no doubt, I think, of the identity of the species described separately by Prof. Dana and Sir John Lubbock.

\section{Pontella plumata, Dana (Pl. XXXVII. figs. I-11).}

Pontellina plumata, Dana, Crustacea, U. S. Expl. Exped., p. 1135, pl. lxxix. fig. 10, $a_{*}-d$. " turgida, of, idem, ibidem, p. 1136, pl. lxxix. fig. 11, a.b., fig. I2, a.t.

Length, 1-12th of an inch $(2 \cdot 1 \mathrm{~mm}$.). Cephalothorax of the female, seen from above, very broadly ovate, scarcely twice as long as broad, rounded off in front, posterior lateral angles rounded or scarcely angulated, rostrum slender, adpressed; figure of the male rather less tumid. Anterior antennæe (fig. 2) about as long as the body of the animal, twenty-one-jointed (?), slender, sparingly setose, most of the joints bearing one or two small apical and marginal setæ, and several of them-notably the fourth, fifth, sixth, thirteenth, fourteenth, fifteenth, eighteenth, and twentieth, having also single long ciliated setæe, the last joint having four long terminal setæ of the same character; the central joints of the right antenna in the male (fig. 3) are very much and abruptly swollen, the first of the swollen joints bearing a rigid, geniculated seta, the last a strong tooth and a series of fine marginal setæ; the limb beyond this point-being at least half its length-is divided into three very long and slender joints, the first of which is finely setiferous or denticulated throughout its entire length, while the next joint bears a short, sub-crescentic series of about twelve similar setæ on its upper half; between these two joints the antenna is hinged. The setæ of the posterior antennæ in the female (fig. 4) are profusely plumose, remarkably long, and reaching, in the natural position of the limb, nearly, if not quite to the extremity of the body of the animal (fig. 1); the secondary antennal branch is about half as long as the primary. The two branches of the mandible-palp are respectively two- and three-jointed (fig. 5), and their setæe are also extremely long. Posterior foot-jaw very small. The first pair of swimming feet (fig. 6) has its inner branches three-jointed, the outer marginal spines very slender; the terminal spines of the following pairs of feet (fig. 7) are straight and narrow, with finely pectinated margins. In the male, the fifth foot (fig. 9) of the right side has the third joint broadly quadrate, with a strong, falcate, lateral process, the terminal claw 
very stout and bent almost rectangularly; the foot of the left side is simple, its last joint hearing a few small apical setæ. The fifth pair in the female are very slender (fig. 8), the penultimate joint giving attachment to two slender, one-jointed branches, the inner short and bearing two small apical setæ, the outer about thrice as long, with one marginal and four long apical setæ. Abdomen of the male five-jointed (fig. 11), its third joint with a large protuberance on the right side; caudal segments rather longer than broad, setæ five, equal. In the female there are six non-spathulate tail setæ (fig. 10), the second, counting from the inside, thinner than the rest and not ciliated.

Habitat.-Off Port Jackson, Australia; between Api and Cape York; between Arrou and Banda; off Kandavu, Fiji ; off the north of Papua; off the Philippine Islands; and off St. Vincent, Cape Verde.

This seems to be one of the most widely distributed of the pelagic Entomostraca, though seldom or never occurring in very large numbers. Prof. Dana gives a long list of localities in which he found it, and I do not doubt that the form named by him Pontellina turgida is referable to the male of Pontellina plumata. It is remarkable that the setæ of the mandibles and antennæ, which, on account of their length and dense ciliation, form so unique a feature in the female, are of no great length and scarcely at all plumose in the male.

** Head with lateral spines ; apez of posterior fcot-jaw four-jointed.

5. Pontella laevidentata, n. sp. (Pl. XXXVIII. figs. 1-6).

Length, 1-15th of an inch (1.6 mm.). Cephalothorax elongated, cylindrical, posterior angles spinous, that of the right side doubly spined; sides of the head produced near the front inito two recurved spines. Right anterior antenna of the male (figs. 2 and 3) only moderately swollen, one joint on each side of the hinge provided with a minutely serrated marginal plate; at the proximal extremity of the upper and distal extremity of the lower plate is a long, adpressed, curved spine, pointing towards the apex of the antenna. Swimming feet slender, with very slender terminal spines. Fifth pair of feet of the male (fig. 5) one-branched, that of the right side doubly hooked, that of the left terminating in three unequal, crooked spines, the longest of which (fig. 6) has a villous enlargement at the base.

Habitat.-Taken off Sibago Island, Philippines, October 23, 1874. One specimen only was found, and the structure of the lower foot-jaw was not accurately noted.

6. Pontella kröyeri, n. sp. (Pl. XXXIX. figs. 1-19).

Length, 1-11th of an inch $(2.3 \mathrm{~mm}$.). Cephalothorax robust, lateral posterior angles forming stout triangular acuminated processes. Anterior antennæ (fig. 2) twenty-three- 
or twenty-four-jointed, longer than the eephalothorax, the basal joints very indistinctly separated, rather sparingly setiferous; right antenna of the male (fig. 3) having two denticulated joints, the proximal end of the first plate forming a free sub-crescentic or club-shaped process, which bears a series of broad recurved teeth, following which is a row of six or seven still larger spines, graduated in size from the middle, where they are longest; the teeth of the main portion of the plate, as also those of the following joint, are very fine and close-set; the antepenultimate joint is produced externally into a dagger-shaped, adpressed spine, equal in length to the penultimate joint. The joints of the right fifth foot in the male (fig. 11) are all broad and subquadrate, the third bearing a long curved terminal claw, and a similar immovable finger at its upper angle; the third joint of the left side has two apical spine-like setæ, and two small roughened or tuberculated finger-like papillæ (figs. 12 and 13). The fifth foot in the female (fig. 10) has a broad quadrate basal joint, to which are attached two simple, curved, one-jointed branches, the inner only half as long as the outer. The abdomen of the male (figs. 18, 19) is five-jointed, and sometimes has the ventral angle prominently spined; the female abdomen is two-jointed (figs. 14-17), and usually has the lower margins of the segments irregularly fimbriated or spinous; the first segment has also on the ventral aspect three or four slender curved processes of variable size. The second tail seta, counting from the inside, is usually longer than the rest.

Habitat.-Arafura Sea, lat. $8^{\circ} \mathrm{S}$., long. $136^{\circ} \mathrm{E}$; off Sibago Island and at other places amongst the Philippine Islands.

This species-unless two or three are here mixed up under one specific name-is subject to a good deal of variation, especially in the peculiar distortions or outgrowths of the abdominal somites, some of which are figured in our plate; the fifth pair of feet, also, in both sexes, presents minor variations of form.

Several species very nearly allied to this have been described by different authors, but none of them seem to admit of complete identification with it. Among its very near relatives may be mentioned Pontella strenua and Pontella valida, Dana; Pontella helgolandica and Pontella gigantea, Claus, and Labidocera darwinii, Lubbock.

*** Head with lateral spines; apex of posterior foot-jaw six-jointed.

\section{Pontella elephas, n. sp. (Pl. XXXVIII. figs. 7-14).}

Length, 1-8th of an inch $(3 \mathrm{~mm}$.). Cephalochorax pointed in front, with recurved spines on each side of the head, posterior angles rounded off. Anterior antennæ shorter than the cephalothorax, twenty-three-jointed (fig. 8), densely setiferous towards the base, more sparingly beyond. Right anterior antenna of the male (fig. 9) thick and short; the teeth of the one denticulated plate (figs. 10, 11) are short and stout, and blunt at the 
apices; the two joints on the proximal, and one on the distal side of the prehensile plate, are armed with curiously flexuous, blunt, spine-like processes, and some of the ordinary setæ are ringed. The fifth pair of feet in the male (fig. 13) are small, the last joint of the right side quadrilateral, and bearing two long falcate claws; that of the left side has a few short blunt apical claws. In the female, the fifth foot (fig. 12) has two terminal branches, the inner minute, awl-shaped, and sometimes bearing a slender hair at the apex, the outer much longer and having four marginal spines. The abdomen of the female is two-jointed, the first joint very large (fig. 14), and having two lateral protuberances; the caudal setæ are subequal, about as long as the abdomen; in the male one of the setæ of each side is much longer than the rest.

Habitat.-Only very few specimens of this species were observed in gatherings from off Sibago Island, and other localities in the neighbourhood of the Philippine Islands. I cannot identify these with any described species. It may be noted that the jointing of the basal part of the anterior antennæ is often very indistinct, as in other species of Pontella; in some specimens I cannot count more than eighteen or nineteen joints, nor does this seem to depend upon immaturity.

\section{Pontella strenua, Dana (P1. XLV. figs. 16-19).}

Pontellina strenua, Dana, Crust. U. S. Expl. Exped., p. 1158, pl. lxxxi. fig. 4, $a-d$.

Male.-Posterior thoracic angles acutely produced, that of one side much longer than the other; abdomen five-jointed; superior eye large, and situated in the base of the rostrum, inferior two in number, small, remote, and a little behind the base of the rostrum. The joints immediately above and below the geniculation of the right anterior antenna are provided with strongly pectinated marginal plates, which do not form excurrent projections; near the extremity of the distal pectinated plate there is, however, a simple slightly curved spine (fig. 16). The terminal spines of the swimming feet are long and slender, and not so finely pectinated as usual in the genus.

Specimens which I refer to this species were taken between Sydney and Wellington, and at night in the South Atlantic, October 5, 1873, near lat. $28^{\circ} \mathrm{S}$., long. $30^{\circ} \mathrm{W}$. The animals were not perfect, and differed slightly in some particulars, probably dependent on age, as for instance in the shape of the abdomen, two forms of which are shown in figs. 18 and 19.

\section{Pontella inermis, n. sp. (Pl. XLV. figs. 10-15).}

Length, 1-5th of an inch $(5 \mathrm{~mm}$.). Head separate and acutely pointed in front, produced behind into two small backward-pointing lateral spines; eyes two, not very widely separated; posterior thoracic angles acute, but rot greatly produced (fig. 10). 
Abdomen of the male (?) four-jointed. Anterior antennæ twenty-three-jointed on the right, twenty-four-jointed on the left side, very sparingly setose (figs. 11, 12), the joints indistinct towards the base, the seventeenth and eighteenth joints of the right side are longer than the neighbouring joints, and the eighteenth bears at its apex a not very long and simple spine, but there is no distinct geniculation or serratures. The marginal spines of the swimming feet (fig. 14) are simple, the terminal ones dagger-shaped and minutely pectinated. The fifth pair of feet are simple, last branch three-jointed, terminal joints bearing short marginal spines.

This species, of which I bave seen only two examples, was taken off Ascension Island (Station 344). Except for the swollen and spiniferous right antenna, I should probably have set them down as females, the characters of the fifth pair of feet being such as are commonly found in that sex. There is an appearance of immaturity in the indistinct jointing of the anterior antennæ, but the size of the animal and the full development of the swimming feet do not support that idea. On the whole it seems best to assign the specimens a distinct specific name.

10. Pontella securifer, n. sp. (Pl. XLV. figs. 1-9).

Right anterior antenna (fig. 1) of the male very tumid in the middle (ninth, tenth, and eleventh joints), the ninth'bearing a long and stout spine, the twelfth a hatchetshaped process, its outer margin bordered with a serrated plate, thirteenth joint simple, fourteenth with a marginal pectinated plate, last joint (fourteenth) very long and slender; a geniculation between the twelfth and thirteenth joints. Inner branch of the first pair of swimming feet three-jointed, - of the second, third, and fourth pairs two-jointed in both sexes. Abdomen of the male three- (fig. 7), of the female (figs 8, 9) two-jointed, very short, and curiously distorted. Rostrum and eyes (figs. 2, 3) as in Pontella strenua.

I have seen only two or three specimens from a gathering made in Mid-Pacific, August and September 1875.

11. Pontella magna, Lubbock.

Labidocera magna, Lubbock, Ann. and Mag. Nat. Hist., ser. 2, vol. xi. (1853), p. 208, pl. x. figs. 8-11.

A few specimens occurred in a gathering from the South Atlantic (lat. $37^{\circ} 38^{\prime} \mathrm{S}$, long. $39^{\circ} 36^{\prime} \mathrm{W}$.). Sir John Lubbock's specimen was also from the South Atlantic, lat. $18^{\circ} 40^{\prime}$ S., long. $2^{\circ} 30^{\prime} \mathrm{W}$. 


\section{Family II. Cyclopid ж, Baird (in part).}

Body elongated, in general outline similar to that of the Calanidæ; anterior antennæ of moderate length, rarely longer than the cephalothorax; those of the males alike on both sides, and geniculated for clasping; posterior four-jointed, and without a secondary branch. Mandibular and maxillary palps well developed or occasionally rudimentary. Foot-jaws much like those of the Calanidæ. First four pairs of feet alike, two-branched, and adapted for swimming only; fifth pair rudimentary, alike in both sexes. Heart wanting. Eyes of the two sides coalescent in the median line. Ovisacs two.

'The absence of an internal branch of the posterior antenna, the rudimentary character of the fifth foot, alike in both sexes, and, in the male the modification of both right and left anterior antennæ, to act as clasping organs, distinguish this Family from those already described, while, from the Harpacticidæ it is separated chiefly by the structure of the foot-jaws and first pair of swimming feet. Except the genus Oithona, no members of the Family have been observed in the Challenger gatherings.

\section{Oithona, Baird, 1843.}

Body much elongated, slender; head quite distinct from thorax. Anterior antennæ long and slender. Mandible-palp elongated, two-branched; secondary branch composed of several joints. Maxillæ stout, and provided with a short two-branched palp. First pair of foot-jaws long and slender, four-jointed (not unlike those of Calanus); second pair also as in Calanus, but indistinctly jointed. All the branches of the first four pairs of feet are three-jointed; fifth pair rudimentary, bearing two small setiferous papillæ.

This genus partakes of the characters both of the Cyclopidæ and Calanidæ, and is perhaps in general appearance more like Acartia (Dias) than any other genus; in this situation it was placed by Dana. But inasmuch as some of the most important features of the Cyclopidæ are present in Oithona, it seems best to consider it as belonging to that Family. The geniculated form of both anterior antennæ in the male, the absence of a secondary branch in the posterior antennæ, the very rudimentary form of the fifth pair of feet, and the presence of two ovisacs, are all characters in which it agrees with Cyclops. The structure of the internal organs also conforms to that of Cyclops.

Oithona challengerii, n. sp. (PI. XL. figs. 1-10).

Length, 1-14th of an inch (1.8 mm.). Cephalothorax narrow, tapered towards the anterior extremity, and produced into a curved beak (fig. 2); abdomen nearly as long as

(ZOOL, CHALL, EXP.—PART XXII.-1883.) 
the cephalothorax, very narrow, and equal in diameter throughout its entire length, fivejointed, the various joints nearly equal in length. Anterior antennæ (fig. 1) composed of thirteen joints, of which the second and third and the last four are very short and nearly equal, the fourth, fifth, and niuth being the longest; the proportionate lengths of

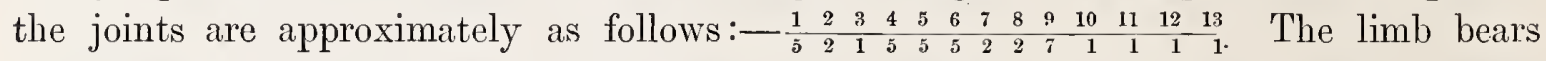
about twelve very long and slender setæ. The maxilla (fig. 4) has a stoutly armed prehensile portion and a well-developed palp, to which is attached a trisetose branchial (?) plate. The first pair of swimming feet (fig. 7) has both branches three-jointed, the outer branch bearing a marginal series of small aculeated spines; the branches of the following three pairs are also three-jointed (fig. 8), but have no marginal spines. The terminal spines of all the feet are excessively long and slender, and are finely pectinated on the outer margin. The fifth foot (figs. 1, 9, 10) consists of a small tubercle, to which are attached two long biarticulate setæ. Caudal segments slightly divergent, nearly as long as the preceding abdominal segment, each bearing six plumose setæ, four of which are about as long as the abdomen; one of these arises from near the base of the external margin; two others-the innermost and outermost of the apical seriesare much shorter than the rest.

Dana has described three species of Oithona, Claus two, and Boeck two, but none of these seem quite to agree with the form which occurs in several of the Challenger gatherings. The animal, however, is so fragile, and so difficult of examination, that it is quite possible that errors of observation may have affected the descriptions both of myself and other authors. But, so far as I can make out, the antennæ of this species are certainly thirteen-jointed. Dana assigns only seven joints to those of all his species, and I cannot but think that he must have failed to observe them correctly. Claus's species have respectively ten and twelve joints. The present species approaches most closely to Oithona spinirostris, Claus, and perhaps to Oithona setiger, Dana, but the differences are too considerable to allow of our safely referring it to either of these. Though examples of Oithona were noticed in very many of the surface-gatherings of the Challenger, I have not been able to recognise differences requiring their reference to more than one species. The form doubtfully referred in the general list of species (p. 5) to Oithona spinirostris, Claus, I cannot on re-examination distinguish from the present species.

Specimens which I refer to this species were found in the produce of the surface-net from the following localities :-Off the south of Papua; off Port Jackson, Australia; west of the Pbilippine Islands (Station 206); in Hilo Harbour, Sandwich Islands, abundantly; in lat. $42^{\circ} 32^{\prime} \mathrm{S}$., long. $56^{\circ} 27^{\prime} \mathrm{W}$. (Station 318); lat. $32^{\circ} 24^{\prime} \mathrm{S}$., long. $13^{\circ} 5^{\prime} \mathrm{W}$. (Station 335 ) ; lat. $12^{\circ} 16^{\prime} \mathrm{S}$., long. $13^{\circ} 44^{\prime} \mathrm{W}$. (Station 341 ); lat. $9^{\circ} 43^{\prime} \mathrm{S}$. , long. $13^{\circ} 51^{\prime} \mathrm{W}$. (Station 342); in all the Stations between lat. $3^{\circ} 10^{\prime} \mathrm{N}$., long. $14^{\circ} 51^{\prime} \mathrm{W}$.; and lat. $10^{\circ} 55^{\prime} \mathrm{N}$., long. $17^{\circ} 46^{\prime} \mathrm{W}$. (Stations $348-352$ ); and in lat. $26^{\circ} 21^{\prime} \mathrm{N}$., long. $33^{\circ} 37^{\prime} \mathrm{W}$. (Station 353). 


\section{Family III. Hanpacticide, Claus.}

Body cylindrical, or occasionally depressed. Abdomen, in most cases, not sharply separated from the cephalothorax. Anterior antennæ slort, composed of few (4-10) joints, and scarcely erer reaching beyond the posterior margin of the first body-segment; in the male adapted on both sides for clasping. Posterior antennæ two- to four-jointed, and provided with a small one- to four-jointed secondary brancl. Mandibles strongly toothed; palp either simple, consisting of one or two joints, or nore complex, and composed of a basal portion with two branches. Maxillæ usually well developed, consisting of a dentated cutting segment and a more or less complex palp, which is made up of several setiferous digits, arranged in a somewhat radiated manner. Anterior footjaws armed at the apex with several strong teeth, and on the inner margin with several (usually three) wart-like, setiferous processes. Posterior foot-jaw sometimes foot-like, but mostly in the form of a prehensile hand. First pair of feet mostly different from the following pairs, and converted into a prehensile apparatus ; second, third, and fourth pairs adapted for swimming; fifth pair two-jointed, foliaceous, different in the two sexes, the basal joint usually dilated and embracing the smaller apical joint. Eyes as in Cyclops. Heart wanting, copulative organs in the female symmetrical, in the male usually asymmetrical. Ovisac single, or rarely double.

The number of Harpacticidæ taken during the cruise is very inconsiderable, belonging to eight different genera; and as many species. The genera represented are the following: --Ectinosoma, Pseudothalestris, Zaus, Miracia, Machairopus, Pontostratiotes, Goniopsyllus, and Setella; of these all but Ectinosoma, Zaus, Miracia, and Setella are new.

\section{Ectinosoma, Boeck. \\ Ectinosoma, Boeck, Oversigt Norges Copepoder, 1864.}

Body much elongated, slender; abdomen not separated from the thorax by any distinct constriction, and remaining unflexed on the body after death. Head small, united with the first thoracic segment. Anterior antennæ very short, much attenuated towards the apex, five- to seven-jointed, bearing numerous long setæ. Posterior antennæ much larger and stronger, three-jointed, and bearing on the first joint a long two- or threejointed secondary branch; the last joint bears several strong, spine-like plumose hairs. Mandible slender, deeply cleft at the apex; palp large, two-jointed, bearing several long setæ, and a short, simple, secondary branch, which arises from the first joint. Basal joint of the maxilla strongly clawed, palp divided into numerous marginal setiferous lobes. Anterior foot-jaws two-jointed, broad, provided with two strong terminal claws and marginal setæ; posterior three-jointed, long and slender, second joint the longest. Four pairs of swimming feet, all nearly alike, two-branched, each branch composed of three nearly equal joints. Eacl foot of the fifth pair is composed of two angular setiferous laminæ. 
Ectinosoma atlanticum (?) (Brady and Robertson), (Pl. IV. figs. 10-14).

Microsetella atlantica, B. and R., Ann. and Mag. Nat. Hist., ser. 4, vol. xii. p. 130, pl. ix. figs. 11-16 (1873).

Ectinosoma atlanticum, Brady, Monograph of the British Copepoda, vol. ii. p. 13, pl. xxxviii. figs. 11-19.

Length, 1-45th of an inch ( $53 \mathrm{~mm}$.). Body very slender, almost linear, much attenuated both behind and in front; tail-segments very short and divergent. First four pairs of feet long and slender (fig. 12), outer branches slightly shorter than the inner, each joint bearing a long, slender, apical spine, and pectinated on its outer edge; median joint only of the inner branch pectinated. Fifth pair of feet (fig. 13) rudimentary, two-jointed; internal portion of the basal joint produced nearly as far as the apex of the second joint, and bearing two apical setæ, one of which is very long; second joint smaller, and bearing two long and one or two very short setæ. Caudal segments bearing two principal setæ, one of which is longer than the body of the animal, the other about half as long. . The posterior borders of the last three abdominal segments are finely and densely pectinated (fig. 14).

The foregoing imperfect description gives, with as much accuracy as could be obtained from observation of only a single specimen, the characters of the species. Though differing very slightly from those of Ectinosoma atlanticum, I cannot venture on such slender grounds to assign to this single example a new specific name. It was taken in the tow-net down to 200 fathoms, on the 9 th of April 1876, in lat. $3^{\circ} 10^{\prime} \mathrm{N}$., long. $14^{\circ}$ $51^{\prime}$ W. (near Ascension Island).

Dr. Giesbrecht has recently ${ }^{1}$ proposed to split up the genus Ectinosoma, leaving in it, if I rightly understand him, only one species, Ectinosoma gothiceps, Giesbrecht. But the grounds for this proposal are as yet given only in a very cursory way, and, so far as I can judge, are insufficient. Should the present species eventually be assigned to a different genus, the name Microsetella (withdrawn in the Monograph of the British Copepoda) must be reinstated.

\section{Pseudothalestris, n. gen.}

Like Thalestris, except as to the structure of the first pair of feet, in which the outer branch is very short and only two-jointed, the inner branch long, three-jointed, having the first joint very long, the second and third rudimentary.

1 Vorläufige Mittheilung aus einer Arbeit über die frei lebenden Copepoden des Kieler Hafens Zool. of Anzeiger, No. $83,1881$. 
Pseudothalestris imbricata, n. sp. (Pl. XLII. figs. 1--8).

Male.-Anterior antenna (fig. 1) eight-jointed, moderately setiferous, and provided with a long and stout olfactory filament. Inner branch of posterior antenna (fig. 2) small, two-jointed. Hand of the posterior foot-jaw (fig. 3) oval and armed with one seta on the inner margin, terminal claw long and slender. Peduncle of the first pair of feet (fig. 4) armed at the base of the inner branch with a crescentic series of stout teeth; first joint of the inner branch about five times as long as broad, setose on the outer and having a single seta near the middle of the inner margin; second and third joints together only about one-fifth as long as the first joint, terminal claw slender, nearly straight, more than half as long as the first joint, and marginally pectinate; outer branch two-jointed, with very stout marginal and terminal spines. Inner branch of the second pair (fig. 5) two-jointed, the second joint being composed of two coalescent joints; outer branch three-jointed, with very large and stout marginal spines. Both branches of the third and fourth pairs three-jointed (fig. 6). The fifth foot (fig. 7) has the two joints nearly equal in size, inner segment of the first joint with three moderately long, subequal, apical setæ; second joint quadrate, bearing five setæ, one of which is much longer than the rest. The joints of the abdomen (fig. 8) are short, and overlap very much at the sides. The longest of the tail setre is about twice as long as the abdomen.

Only one specimen of this species was found, its characters being intermediate between those of Dactylopus and Thalestris. The second, third, and fourth pairs of feet agree closely with Thalestris, while the first foot, except as to the two-jointed outer branch, is very similar to the same limb in Dactylopus. 'Ihe female has not been seen.

Habitat.-Betsy Cove, Kerguelen Island.

\author{
Zaus, Goodsir. \\ Zaus, Goodsir, Ann. and Mag. Nat. Hist., 1845.
}

Body broad and depressed; head distinct from eephalothorax, rostrum broad and truncated. Anterior antennæ nine-jointed; posterior two-jointed, secondary branch two-jointed. Mandibles strongly toothed, palp two-branched. First pair of feet twobranched, its outer branch two-jointed, twice as long as the inner; inner branch twojointed, the second joint rudimentary; ovisac large, adpressed, single. Second, third, and fourth pairs of feet with both branches three-jointed; fifth pair foliaceous, twojointed. 
Zaus spinatus, Goodsir (Pl. XL. figs. 12-16, and Pl. XLI. figs. 13-17).

Zaus spinatus, Goodsir, On several new species of Crustaceans allied to Saphirina, Ann. and Mag. Nat. Hist., vol. xvi. p. 326, pl. xi. figs. 1-8 (1845); Brady, Monograph of British Copepoda, p. 153, pl. lxvi. figs. 1-9 (1880).

" spinosus, Claus, Die frei lebenden Copepoden, p. 146, pl. xxii. fig. 25, pl. xxiii. figs. 1-10 (1863) ; Boeck, Oversigt Norges Copepoder, p. 40 (1864).

This well-known European species needs no detailed description here. The specimens brought home by the Challenger were taken in Balfour Bay, Kerguelen Island, and differ in no respect from those found in Europe, except, perhaps, that the marginal cilia of the spines of the fcet and posterior antennæ are somewhat less fully developed.

Zaus spinatus affords an interesting illustration of the close resemblance borne by the Kerguelen Island Entomostracan fauna to that of Northern Europe,-a matter already noticed in the preface.

\section{Miracia, Dana.}

Miracia, Dana, Proc. Amer. Acad. Sci., 1849.

Body subcylindrical; forchead produced into a short blunt rostrum. Anterior antennæ eight-jointed, short, in the male geniculated, but without any vesiculiform enlargement. Posterior antennæ two-jointed, and bearing a small single-jointed secondary branch. Maxilla toothed and broad at the apex, and provided with a small (one- or two-jointed ?) setiferous palp. Mandible composed of a toothed cylindrical segment, without a palp. Anterior foot-jaw small, divided into several small marginal setiferous processes. Posterior much larger, two-jointed, joints long and narrower, the last truncated at the apex and bearing a short falciform claw. Four pairs of feet adapted for swimming and nonprehensile; fifth pair foliaceous. Eyes very prominent, placed in the forehead, and covered with two confluent refracting lenses. Abdomen four-jointed in the female, five-jointed in the male.

\section{Miracia efferata, Dana (Pl. XLIII. figs. 1-16).}

Length, 1-12th of an inch (2·1 mm.). Integument tough; bodyslender, ten-jointed, with distinct constrictions between the several somites; abdomen nearly equalling the cephalothorax in length. Eyes composed of two large confluent and extremely prominent lenses, situated on the very front of the head (figs. 2, 16). Anterior antennæ shorter than the first body segment, eight-jointed; in the female (fig. 4) slender, and gradually tapering to the apex; the third, sixth, and eighth joints are the longest, nearly equal, and together make up half the length of the limb; the fifth and seventh joints are the shortest; each joint bears about two or three setæ of moderate length, and the fourth has a rod-like 
olfactory filament; in the male (fig. 3) the antenna is geniculated, and has a slender clawlike apical joint. The posterior antemna (fig. 5) is two-jointed and cylindrical, the first joint having attached near the middle a minute one-jointed branch, which bears two stout pectinated setæ, the last joint about half as long as the first, and provided with four apical setæ of unequal length, and bearing also a small seta on the outer margin. Mouthorgans extremely minute. Mandible simple, cylindrical (fig. 7), obscurely toothed at the apex, and beset on one margin with a series of closely-set fine hairs. Maxilla (fig. 6) short, quadrate, truncated, and strongly toothed at the apex, bearing a small simple palp, which has a large marginal seta and three smaller apical ones. Anterior foot-jaw (fig. 8) short and stout, divided into several (about four) stout marginal setiferous digits; posterior (fig. 9) elongated, narrow, two-jointed; first joint bearing only a single small marginal hair, second truncated and serrated at the apex, which is armed with a short and stout hook-like claw; the first joint about five times, the second three or four times, as long as broad. The second, third, and fourth pairs of feet are nearly alike, and the same in both sexes (except the second pair of the male), having both branches three-jointed and of nearly equal length; the first pair is similar in male and female (fig. 10), and differs from the rest in having the inner branch composed of only two joints, and in being less profusely setose; the inner branch, too, is slightly longer than the outer; in the male the inner branch of the second pair (fig. 11) is two-jointed, the last joint being composed apparently of the coalescent second and third joints; fifth foot (figs. 13, 14) composed of two foliaceous joints, not very dissimilar in the two sexes, the basal joint fringed with four or five, the apical with six stout setæ. The first abdominal segment in the female is formed by the confluence of two somites, and shows a more or less distinct division into two parts, in the male, the first segment has the postero-ventral angle produced and setiferous (fig. 15); caudal stylets cylindrical, about thrice as long as broad; terminal setæ three, the longest being considerably shorter than the abdomen. The ovisacs of the female contain only a small number of very large ova.

Habitat.-Lat. $40^{\circ} 3^{\prime}$ S., long. $132^{\circ} 58^{\prime} \mathrm{W}$. (Station 288); and lat. $5^{\circ} 28^{\prime} \mathrm{N}$., long. $14^{\circ} 38^{\prime} \mathrm{W}$. (Station 349). In the first-named locality only one specimen, a male, was found; in the second several specimens, all of which were females. A few specimens were taken in Mid-Atlantic (Station 99), and mounted alive during the cruise, thus preserving the colours of the living animal,- the body a brilliant bluish-green, cornea smoky yellow; from all the spirit-specimens the colour las entirely fled.

I have not been able to find the "falciform appendages" described by Dana; probably these correspond to the blunt frontal prominence which I call the rostrum. Except in the relative lengths of the antennal joints, the Challenger specimens agree closely with Dana's description of Miracia efferata, the anterior antenna of which is said to be seven-jointed, the third, fifth, and seventh joints being the shortest. I cannot at all explain the discrepancy, and possibly the two may prove to be distinct; but for the 
present, it seems best to keep them under one specific name. One of the localities given by Dana corresponds pretty nearly with the Challenger Station No. 349.

\section{Machairopus, ${ }^{1}$ n. gen.}

Cephalothorax broad and rather depressed; abdomen five-jointed in both sexes. Anterior antennæ nine-jointed; inferior three-jointed, with a large three-jointed inner branch. Mandible strong, and provided with a slender two-branched palp. Maxilla(?). Foot-jaws three-jointed, the second pair uncinate and flexed in a geniculated manner. Inner branch of the first pair of feet two-jointed, armed at the extremity with two broad laminated or knife-like appendages in place of claws; outer branch short, three-jointed, and strongly setiferous, second, third, and fourth pairs having both branches threejointed; fifth pair foliaceous, two-jointed. Eyes distinct and widely separated.

In thịs genus the characters are intermediate between Idya and Scutellidium, the antenna, foot-jaws, and mandibles agreeing with the former, while the feet are like those of the latter genus. The only species is

Machairopus idyoides, n. sp. (Pl. XLI. figs. 1-12).

Length, 1-20th of an inch $(1.3 \mathrm{~mm}$.). Cephalothorax much broader than and separated sharply from the abdomen. Anterior antennæ rather densely setiferous, geniculated in the male. The secondary branch of the posterior antenna (fig. 4) is stout, and three- (or four-?) jointed ; the mandible (fig. 5) is tapered towards the apex, and not very strongly toothed; the basal joint of the palp is long and slender, and the branches are composed each of a single joint with five long setæ; the foot-jaws (figs. 6, 7) are both three-jointed, but the second has a longer terminal claw, is more slender, and is flexed upon itself between the first and second joints. The feet of the first pair are exactly as in Scutellidium, the broad lamina and knife-like apical armature of the inner branch being very characteristic (fig. 8); the outer branch is much shorter, and bears several very stout plumose setæ; the last joint is very short and broad, and has five such setæ; the first and second joints have each one or two ; the outer margins of both branches are likewise densely fringed with short, rather rigid hairs. The other swimming feet (fig. 9) have equal, three-jointed branches, with densely pectinated outer margins; marginal spines slender and lancet-shaped; terminal spines long and slender. The basal joint of the fifth foot in the female (fig. 10) is broad and bilobed at the apex, the outer margin bearing a fringe of long, fine, and closely-set hairs, the inner margin less profusely fringed in a similar way; the apex of the outer lobe has three long, slender setæ, the inner lobe one long hair and a series of about eight small tooth-like setæ ; the second joint is long and subovate, has ciliated margins; and five long, unequal apical setæ. The outcr 
angles of the abdominal segments (fig. 11) are pectinated with small spines, and the caudal setæ are finely aculeated along their whole length; the last abdominal segment in the female is very short-almost obsolete-and the distal margins of the last two segments are fringed with delicate spines. The caudal laminæ are about as broad as long, the principal setæ considerably longer than the abdomen, and finely aculeated throughout.

Two or three specimens only found in a gathering from Betsy Cove, Kerguelen Island.

\section{Pontostratiotes, ${ }^{1}$ n. gen.}

Anterior antenıæ (PI. XLIV. fig. 4) ten-jointed; posterior (fig. 5) two-branched, the inner branch four-jointed, springing from the apex of the first joint of the main branch. Mandible very strongly toothed (fig. 6), and bearing a large two-branched palp. Maxilla (fig. 7) stout, bearing numerous stout marginal setæ; first foot-jaw (fig. 8) short and stout, divided into several marginal setiferous processes; second foot-jaw (fig. 9) slender, two-jointed (?), bearing numerous setæ on the apex and inner margin, without a terminal claw. Swimming feet of the first four pairs two-branched, all branches three-jointed (fig. 10) ; fifth pair (fig. 11) one-branched, three-jointed, not foliaceous. Carapace armed with several excessively long and strongly-toothed spines, which are directed backward; anterior antennæ likewise provided with numerous, variously-shaped, spinelike processes.

Pontostratiotes abyssicola, n. sp. (PI. XLIV. figs. 1-11).

Length, 1-15th of an inch $(1.6 \mathrm{~mm})$. The head is extended on the ventral aspect into a strong triangular process, and laterally, just below the base of each anterior antenna, has a stout, slightly curved spine projecting almost at a right angle from the body; the posterior part of the head and anterior part of the thorax have three pairs of very long, strong, and sharply-pointed spines, which are marginally pectinated with numerous sharp tooth-like prickles. The first pair of these spines (fig. 3, $a, a$ ) arises from near the posterior border of the head, at some distance from the middle line of the body, and projects backwards to about the second or third abdominal ring; the second pair $(b, b)$ arises on a level with the first pair, but from the lateral aspect of the body, and projects backwards to a point slightly behind the apices of the first pair; the third pair $(c, c)$ springs from the sides of the first thoracic somite, and being of equal length with the anterior spines, extends proportionately further backwards; the posterior borders of the thoracic and abdominal segments are strongly and irregularly toothed, especially on the dorsal aspect. Anterior antennæabout two-thirds the length of the cephalothorax, ten-jointed, the first two joints nearly

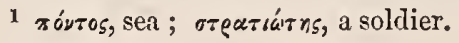

(ZOOL. CHALL. EXP.-PART XXIII-1883.) 
equal, and together longer than the remaining eight joints, the proportionate lengths of

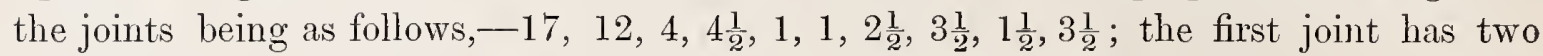
multifid, spined tubercles on its anterior surface, and the posterior surface is armed with a series of short, closely set, blunt teeth; the anterior margin of the second joint has four forward-pointing sub-triangular teeth, and at the apex a much larger dagger-like spine ; the other joints are scarcely at all spinous, but bear several long hairs and an olfactory filament. Posterior antennæ about half as long as the antcrior pair, primary branch composed of four slender, elongated, and nearly equal joints; secondary branch attached to the apex of the first joint of the primary branch, and composed of four joints, of which the two median oncs are very small. The teeth of the mandible are very deeply cleft, strong and sharp ; the joints of the palp long, slender, and bearing long setæ. The first four pairs of fect have both branches three-jointed and of equal length, and the marginal spines of the outer branch are duplicated, having a very long ciliated, awl-shaped spine attached below cach shorter spinc. The fifth foot is one-branched only, composed of three nearly equal joints, the second joint bearing a large marginally aculeated apical spine, the third joint five of similar type, but smaller. The caudal setæ are considerably longer than the body of the animal.

This wonderful species was found-but unfortunatcly one specimen only, and that in a dried state-amongst material taken in the tow-net at trawl, at a depth of 2200 fathoms, lat. $37^{\circ} 29^{\prime} \mathrm{S}$, long. $27^{\circ} 31^{\prime} \mathrm{W}$. This single specimen was apparently much shrunk and distorted, owing to its having been dried amongst the mud in which it was taken, and on this account many of the details of structure have been very imperfectly made out; the tail-setæ, for instance, and the minor details of the mouth-organs were partly indistinguishable, the limbs much matted together, and the natural contours doubtless in other parts much altered.

Considering that this is by far the most remarkable Copepod met with amongst the Challenger captures, one must regret that some means were not found of more completely preserving Microzea, not only from abyssal depths, but from the sea-bed of much shallower water. I have long been aware that it is by such means that the most interesting additions to the micro-fauna of the British seas, at any rate, are to be secured; and I cannot doubt that like processes would give like results in other regions. The method which I have myself successfully adopted is, after sifting out the coarse parts of a dredging, to plunge the fine residue into a quantity of sea water,- - then, after allowing a few moments for most of the inorganic matter to settle, to strain off the supernatant watcr, which, of course, contains most of the swimming Microzoa. These, after being this securcd on a muslin filter, may be allowed to clean themselves by immersion for a short period in a ressc] of salt water, and will then be obtained in a condition suitable for examination. 


\section{Gomiopsyllus, ${ }^{2}$ n. gen.}

Head and first thoracie segment coalescent. Abdomen not much narrower than the ceplialothorax, joints of the cephalothorax very much constricted in front, dilated behind, so as to form prominent lateral triangular processes (Pl. XLIr. fig. 10). Anterior antenna six-jointed (fig. 11), posterior (fig. 12) three-jointed, destitute of a secondary branch. Mandibles wanting (?), maxillæe (fig. 13, a) rudimentary; anterior foot-jaw very small, feebly clawed at the apex (fig. 13, b); posterior (fig. 14) much larger, three-jointed, terminal claw very slender. First four pairs of feet nearly alike (fig. 15) ; two-branched, branches three-jointed; fifth pair (fig. 16) small, consisting of one branch only.

Goniopsyllus rostratus, n. sp. (Pl. XLII. figs. 9-16).

Length, 1-40th of an inch $(0.65 \mathrm{~mm}$.). Seen laterally the body is curved, moderately constricted at the internodes, and tapers evenly but very slightly from the head to the tail; the rostrum broad, prominent, and triangular; seen dorsally cach cephalothoracic segment is narrowed in front, and lias its posterior lateral angles produced, strongly directed outwards and backwards, and terminating in a sharp point. Anterior antennæ six-jointed (?), slender, about as long as the first body segment, sparingly setose; the last joint longer than the three preceding. Posterior antennæ three-jointed, bearing a single long seta in place of a secondary branch. Maxilla rudimentary, consisting of a very small limb, which terminates in a single claw ; anterior foot-jaw small, terminating in three small claw-like setæ; posterior foot-jaw three-jointed, first two joints long, slender, and nearly equal, third rudimentary, apical claw eurved and extremely slender. The first four pairs of feet have the inner branches a little longer than the outer; both branches bearing long setæ but no spines; the fifth pair short, simple, three-jointed, bearing one short and two long terminal setæ. Caudal segments very short; terminal setæ two or threc, very short.

One specimen only-a male- of this curious species was found. It occurred in a tow-net gathering from Station 318 , lat. $42^{\circ} 32^{\prime} \mathrm{S}$, long. $56^{\circ} 27^{\prime} \mathrm{W}$.

Its nearest allies are probably to be found in the genera Enhydrosoma, Boeck, and Cletodes, Brady (=Lilljeborgia, Claus), but the mouth-organs in these genera are totally different in character. In Goniopsyllus the maxillæ and foot-jaws are extremely small, and the mandible appears to be altogether absent; at any rate I was unable to find it. The peculiar bend of the feet upon their basal joint calls to mind a similar conformation in Peltidium, while the absence of a secondary branch in the posterior antenna, and the rudimentary character of the mouth-organs, show an affinity to the Saphirinidæ.

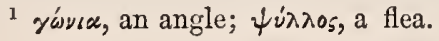




\author{
Setella, Dana. \\ Setella, Dana, Crust. U. S. Expl. Exped. (1852)
}

Body extremely slender, almost linear, and bearing beneath the front of the head a short and broad but sharply-pointed beak-like appendage. Head and first thoracic segment coalescent. Anterior antennæ slender, bearing on the fourth joint an (olfactory?) appendage; posterior antennæ unbranched. Mouth-organs excessively minute. Mandiblepalp rudimentary. Maxillæ and first pair of foot-jaws short and uncinate; second pair of foot-jaws larger, and forming a clawed hand. Fifth pair of feet foliaceous. Caudal setæ very long.

Setella gracilis, Dana (Pl. L. figs. 1-10).

Setella gracilis, Dana, Crust. U. S. Expl. Exped. (1852), p. 1198, pl. lxxxiv. fig. 3, a-g.

Length, 1-18th of an inch $(1.4 \mathrm{~mm}$.). The head is tapered towards the front, and bears a stout, lancet-shaped rostrum. Abdomen in the female four- in the male five-jointed; margin of the penultimate segment finely pectinated; caudal segments slender, as long as the three preceding abdominal segments; principal setæ two, the innermost very long, more than equalling the length of the whole body of the animal, the outer seta about as long as the caudal stylet; both are finely aculeated through their entire length. Anterior antenna slender and very sparingly setiferous, that of the female eight-jointed, about as long as the cephalothorax ; that of the male (fig. 2) geniculated, slightly swollen above the middle, and terminating in a slender slightly falciform joint; posterior antenna (fig. 3) three-jointed, simple, bearing at the apex three small subequal setæ, and two much smaller marginal hairs. Mandible (fig. 4) very small and feebly tooched at the apex; palp consisting of one small seta; maxilla (fig. 5) simple, subhamulate, without a palp; anterior foot-jaw (fig. 6) provided with a stout curved apical seta, and with two or three marginal unisetiferous processes; posterior (fig. 7) elongated, much larger than the preceding, two-jointed, bearing at the apex a short curved claw, and on the middle of the inner margin of the second joint a brush-like tuft of small fine hairs. First four pairs of feet long and slender (fig. 8), two-branched, the branches nearly equal, three-jointed; fifth pair rudimentary, each branch consisting in the female (fig. 10) of a single joint, the apices of both and the outer margin of the outer branch being setiferous; in the male (fig. 9) the inner branch is represented only by a couple of small setæ.

Of this interesting genus Dana has described five species, some of them, perhaps, of doubtful validity; Claus one species, Setella messinensis, from the Mediterranean, and Boeck one, Setella norvegica. The Challenger specimens agree most closely with Dana's Setella gracilis, but the differences between this species and Setella tenuicornis appear to be of the very slightest character. 
Habitat.-The following gatherings contained specimens of Setella gracilis:- Surfacenet collections taken in January and February 1875, off the north coast of Papua, and among thePhilippine Islands ; between Api and Cape York, north of the Sandwich Islands, in lat. $30^{\circ} 22^{\prime} \mathrm{N}$., long. $154^{\circ} 56^{\prime} \mathrm{W}$. (abundant) ; in lat. $36^{\circ} 44^{\prime} \mathrm{S}$., long. $46^{\circ} 16^{\prime} \mathrm{W}$. (Station $325)$; lat. $9^{\circ} 43^{\prime} \mathrm{S}$., long. $13^{\circ} 51^{\prime} \mathrm{W}$. (Station 342 ); lat. $3^{\circ} 10^{\prime} \mathrm{N}$., long. $14^{\circ} 51 \mathrm{~W}$. (Station 348); at Zamboanga (abundant); and in lat. $13^{\circ} 50^{\prime} \mathrm{S}$., long $151^{\circ} 49^{\prime} \mathrm{E}$. (Station 181); in lat. $9^{\circ} 9^{\prime} \mathrm{N}$., lollg. $16^{\circ} 41^{\prime} \mathrm{W}$. (Station 3.51).

\section{Section II. P E C I L O T O M A, Thorell.}

\section{Family I. CoRycaide, Dana.}

Cephalothorax elongated or subpyriform, abdomen much narrower, usually elongated, and distinctly separated from the cephalothorax. Anterior antennæ alike in both sexes (? except in Lubbockia), five or six-jointed ; posterior simple, three- or four-jointed, forming a prehensile hand, which is clawed or armed with curved prehensile setæ at the apex. Mouth-organs (except the posterior foot-jaws) minute, and destitute, or nearly so, of palps. Posterior foot-jaw prehensile, and in the male powerfully clawed. First four pairs of feet alike, or nearly so, adapted for swimming, two-branched, and armed with lancet-shaped lateral spines; fifth pair rudimentary, alike in both sexes; rarely absent. Heart wanting. In addition to two small median eyes, there are usually two lateral eyes, with large, conspicuous lenses (eyes absent in Lubbockia ?) ; ovisacs usually two.

In the Monograph of the British Copepoda, I followed Thorell in separating the Saphirinidæ and Corycæidæ, but liave here adopted the older, simpler, and, as I now think, the more natural plan adopted by Dana and Claus. The Saphirinidæ occupy, in fact, a very similar position in relation to the Corycæidæ, as the Peltididæ to the Harpacticidæ, the differences being more of outward appearance than of structure.

\section{Corycceus, Dana.}

Corycceus Dana, Proc. Acal. Nat. Sci., Philadelphia, 1845."

Body elongated, subcylindrical (Pl. LII. figs. 1, 2); abdomen two-jointed, penultimate segment of the cephalothorax produced ventrally into two hook-like processes, last joint of the cephalothorax very small and overlapped by the preceding joint. Anterior antennæ (fig. 6) six-jointed, short; posterior (figs. 7, 8) uncinate, strongly prehensile, terminal claw longer in the male. Mandibles (fig. $9, a$ ) divided into two apical processes $\left(a^{\prime}, a^{\prime}\right)$, and bearing a small setiferous palp $\left(a^{\prime \prime}\right)$; maxilla (fig. 9, $b$ ) composed of an uncinate lamina and several setiferous marginal processes. Anterior 
foot-jaws (fig. 10) small, alike in both sexes, produced apically into a strong hook-like extremity, and bearing on the inner margin several ciliated seta; posterior foot-jaws (fig. 11) elongated, three-jointed, forming a strongly clawed prehensile hand, the claw larger in the male. First, second, and third pairs of feet with both branches three-jointed (figs. 12, 13), inner branch of the fourth pair (fig. 14) quite rudimentary, or replaced by a single small hair. Fifth pair of feet wanting or excessively minute. Frontal eyes two, each composed of a single, large, colourless, highly refracting lens, situated near the base of the anterior antennæ; median eyes very small.

The principal distinctive characters of this genus are the very large frontally situated corneal lenses, the broad, cylindrical cephalothorax, the very narrow abdomen, consisting only of two-joints and distinctly separated from the cephalothorax, the large, prehensile, posterior antennæ, the one-branched fourth foot, and the absence or very rudimentary characters of the fifth pair. From the most closely allied genus (Sciphirina), the cylindrical, non-complanate character of the cephalothorax and styliform build of the abdomen distinguish it at a glance.

But though the genus is at once and easily recognisable, the indication of specific characters is a most perplexing task. From the large number of gatherings which have come under my notice it would be easy enough to pick out a considerable number,- perhaps half a dozen types,-which, were we to ignore intermediate forms, might serve for the foundation of as many separate species. But there would still remain numerous individuals, not precisely agreeing at all points with the types, but, allowing for slight variations, referable indifferently to several species. The characters upon which, chiefly, the species already described have been founded are,--the general outline of the body, position of the eyes, form of the two pairs of antennæ and posterior foot-jaws, and of the caudal stylets. I have not, however, been able to satisfy myself of the validity of many of the so-called specific distinctions which have been based upon these variations, so that, while not venturing to deny the possible existence amongst the Challenger collections of more species than I have admitted, it seems to me more consistent with the present state of our knowledge to allow a very wide margin for variation, and so to restrict very considerably the number of specific types. I feel sure, for instance, that some of Dana's species are founded upon characters belonging to immature or quite young forms,- the form and proportions of the caudal stylets and the armature of the posterior antenure, being notably, as I believe, variable with the growth of the individual. But without the opportunity of observing accurately the growth and development of the animals, it is of course impossible to speak with absolute confidence on these points. We must always bear in mind the possibility of two or more species being mixed up in the same gathering, and when these are very closely allied, and in various stages of development, it becomes almost impossible to unravel the knot. 
1. Coryccus varius, Dana (Pl. LII. figs. 1-14).

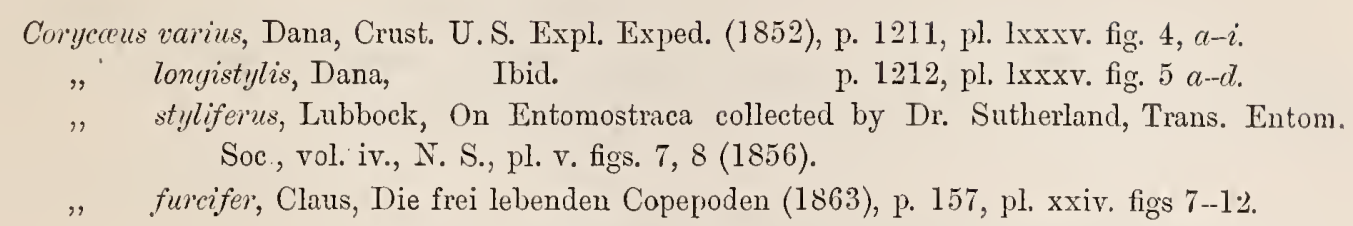

Length, 1-8th of an inch $(3 \mathrm{~mm}$.). Body slender and clongated; third thoracic scgment produced into two long and acutely-pointed lateral processes, which extend as far backwards as the middle of the abdomen (figs. 1, $a, a$, and fig. 3, $a$ ); caudal stylets variable in length, but in the adult many times longer than broad, and usually about twice as long as the abdomen. Anterior antennæ (fig. 6) less than lialf as long as the first segment of the body, six-jointed, the joints of nearly equal length; posterior antennæ (fig. 7 male, fig. 8 female) much larger, and forming a strongly prehensile limb, basal joint bearing two very long spine-like sctæ, sceond joint subquadrate, produced at its inner distal angle into a broad acutely pointed, triangular tooth, third joint small, bearing a few small curved, acuminate setre, and at the apcx an cxtremely long falcate claw, which when flexed on the limb interlocks with the two long setæ of the basal joint. In the female the terminal claws are much shorter than in the male, while the triangular tooth of the second joint is larger. Posterior foot-jaw (fig. 11) prehensile, and armed with a long, falciform apical claw, at the base of which are two small flagellate setæe (fig. 11, a). Inner branches of the first three pairs of swimming feet (figs. 12, 13) very short. Distal extremities of the caudal stylets slightly dilated (fig. 1, a), and giving attachment to several setæ, the innermost being robust and about half the length of the stylet, the second half the length of the first, the third rather longer than the second, but much more slender and flexuose; there is also a small spine at the cuter angle, and a very minute marginal seta a little removed from the apex of the stylet. The eyes are situated quite on the front of the head, quite distinct and remote one from the other towards the side of the body.

Habitat.-Forms which I refer to Corycaus varius occurred in the surface gatherings from a very large proportion of the places visited by the Challenger. The following list of localities shows the wide distribution of the species:-Off Port Jackson, Australia; between Sydney and Wellington; off Kandaru, Fiji; between Api and Cape York; off south of Papua; at many localities amongst the Philippine Islands ; Pacific, north of the Sandwich Islands, in lat. $30^{\circ} 22^{\prime} \mathrm{N}$., long. $154^{\circ} 56^{\prime} \mathrm{W}$. (Station 256); in lat. $36^{\circ} 32^{\prime} \mathrm{S}$, long. $132^{\circ} 52^{\prime} \mathrm{WT}$. (Station 287) ; lat. $37^{\circ} 3^{\prime} \mathrm{S}$, long. $44^{\circ} 17^{\prime} \mathrm{W}$. (Station 326) ; lat. $32^{\circ} 24^{\prime} \mathrm{S}$, long. $13^{\circ} 5^{\prime} \mathrm{W}$. (Station 335) ; lat $12^{\circ} 16^{\prime} \mathrm{S}$., long. $13^{\circ} 44^{\prime} \mathrm{W}$. (Station 341); lat. $9^{\circ} 43^{\prime}$ S., : long. $13^{\circ} 51^{\prime}$ W. (Station 342); lat. $3^{\circ} 10^{\prime}$ N., long. $14^{\circ} 51^{\prime}$ W. (Station 348); in various localities between lat. $5^{\circ} 28^{\prime} \mathrm{N}$., long. $14^{\circ} 38^{\prime} \mathrm{W}$.; and lat. $10^{\circ} 55^{\prime} \mathrm{N}$, long. $17^{\circ}$ 
$46^{\prime}$ W. (Stations 349-352) ; in lat. $26^{\circ} 21^{\prime}$ N., long. $33^{\circ} 37^{\prime} \mathrm{W}$. (Station 353); in lat. $13^{\circ} 50^{\prime}$ S., long. $151^{\circ} 49^{\prime}$ E. (Station 181).

The list of synonyms which I have assigned to this species might, I feel sure, be very considerably enlarged, some of the forms described by various authors being, as I think, founded upon stages of development of Corycaus varius.

2. Corycceus pellucidus, ${ }^{1}$ Dama, (Pl. LII. figs. 15-19).

Corycceus pellucidus, Dana, Crust. U. S. Expl. Exped. (1852), p. 1224, pl. lxxxvi. fig. 6. " rostrutus, Clans, Die frei lebenden Copepoden (1863), p. 157, pl. xxviii. fig. 5.

Length, 1-26th of an inch (.97 mm.). Body moderately elongated; abdomen short and composed of one joint only (fig. 15) ; first body-segment produced between the footjaws and the first pair of swimming feet into $\lambda$ broad conical prominence ; third thoracic segment produced into broadly triangular lateral processes reaching to the middle of the abdomen, and completely hiding the fourth segment. Anterior antennæ (fig. 16) sixjointed ; posterior not very powerfully prehensile (fig. 17), basal joint long and bearing two long, plumose, spine-like setæ, second joint narrow, and possessing no marginal teeth; terminal claw short and weak. Posterior foot-jaw (fig. 18) small, and bearing on the inner margin of the hand a small plumose hair. Caudal stylets (fig. 19) much shorter than the abdomen, about four or five times as long as broad, the terminal setæ short. All the specimens seen were females, and many of them had attached to the abdomen bundles of spermatic tubes, very large for the size of the animal, and tapering to each extremity. These are shown in fig. 19.

A few specimens only of this species occurred in the following gatherings:--South Pacifie, December 5, 1875 ; in lat. $36^{\circ} 44^{\prime}$ S., long. $46^{\circ} 16^{\prime} \mathrm{W}$. (Station 325 ); in lat. $9^{\circ}$ $43^{\prime}$ S., long. $13^{\circ} 51^{\prime}$ W. (Station 342); and at St. Vincent, Cape Verde Islands.

The following interesting remarks of Dr. . Willemoes Suhm refer to a species which appears to be identical with Corycaus pellucidus, the only important differences between our specimens and $\nabla$. Willemoes Suhm's figures being found in the pectoral process-which in "megalops" is much curved and rather slender, in pellucidus straight and obtusely conical-and the eyes, which in pellucidus, are considerably larger; this latter point, however, need not be much insisted on, as v. Willemoes Suhm especially remarks upon the "extraordinary size" of the eyes. The figures, which are valuable as having been taken from the living animal, are reproduced in the woodcut. Dr. v. Willemoes Suhm's note is as follows :-

Corycceus megalops.-On our way from Teneriffe to St. Thomas, in lat. $23^{\circ} 10^{\prime} \mathrm{N}$., and long. $38^{\circ}$ $42^{\prime}$ W., I found, among the animals which were got by the towing-net on the surface, a little blue Copepod, which especially attracted my attention by the large size of its eyes. The peculiar long 1 In the table of species (p. 5) this is given as Corycreus rostratus. 
pigmented body and the two lenses united by a tube showed at once that this was a member of the family Corycæidæe, and a glance at Leuckart's picture of Corycous germanus proved that this genus, with its rudimentary development of the fifth thoracic ring, was the one to which it belonged. For I do not think that the extraordinary pectoral process into which the pigmented bodies of the eyes extend makes it necessary to establish for this form a new genus. In the following description I shall especially dwell upon those points in which our animal, which I propose to call Coryccus mcgalops, differs from Coryccus germanus, Leuck.
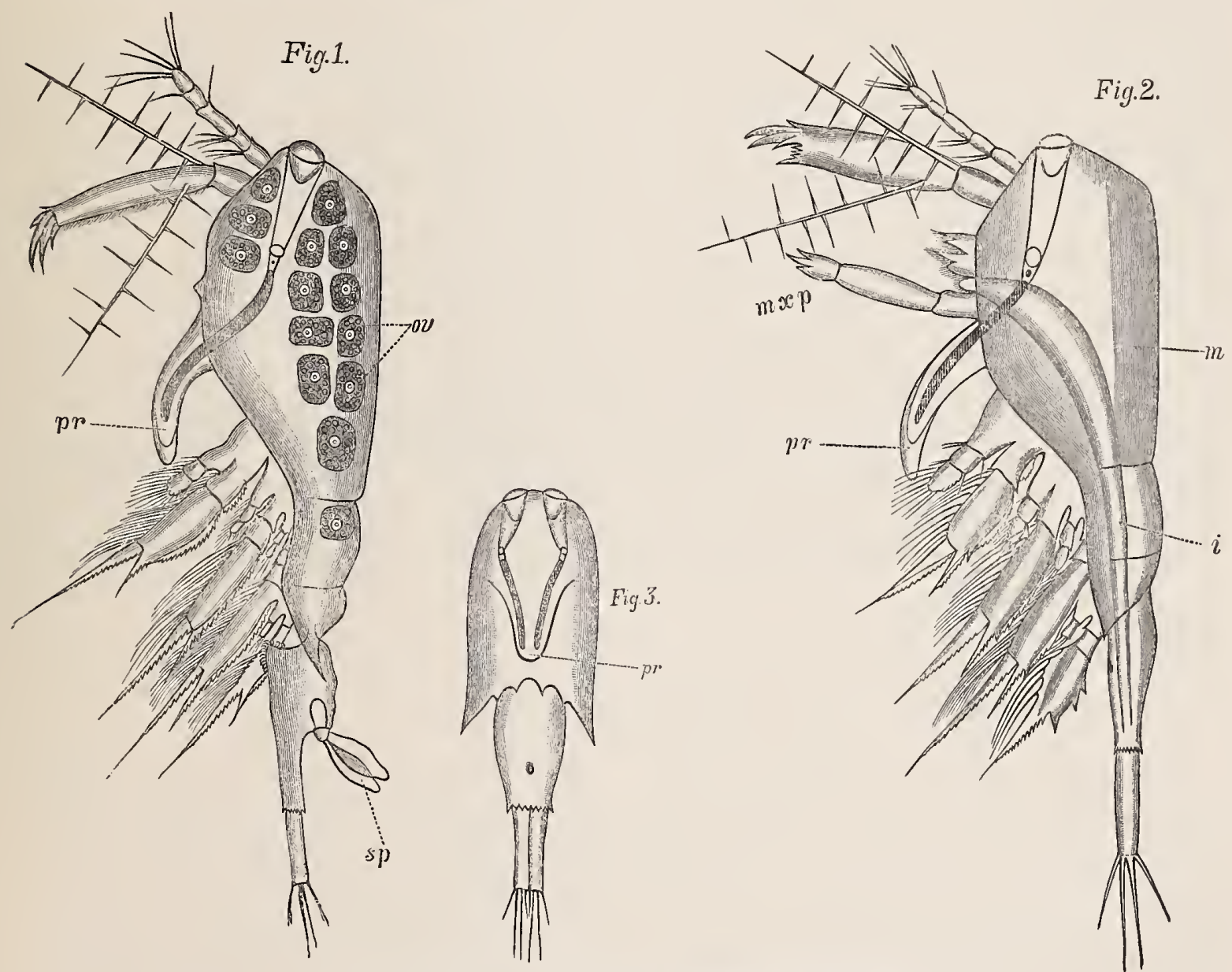

Corycoxus pellucidus, Dana (from Dr ron Willemoes Suhm's figures).

FIG. 1.-Female, seen from left side. FIg. 2.--Male, seen from left side. FIG. 3.-Female, seen from dorsal surface.

$P r$., ocular process ; ov., ova; $s p$., spermatophores; mxp., posterior foot-jaw ; $i$., intestine ; m., dorsal muscles.

The female has a length of $0.87 \mathrm{~mm}$. and a width of $0.35 \mathrm{~mm}$., its somewhat larger size and the blue colour of its ovary distinguish it easily from the male. In both sexes the eyes (which are composed of two lenses, a tube, and a red pigmented body) have an extraordinary size, as the pigmented bodies extend into a pectoral process, which is as long as the first pair of legs and somewhat bent backwards (figs. 1, 2, 3, pr.).

The first antennæ are amply supplied with olfactory hairs in both sexes. The second ones, somewhat larger in the male, are terminated by curved spines, which are espccially numerous in the

(ZOOL. CHALL. EXP.-PART XXIII.-1883.) 
male; they have besides in both sexes two large spiniferous setæ, originating from the base of the last joint. In the mandibles and maxillæ I have not seen anything remarkable; the maxillipedes however, are very large (fig. 2, mxp.), and terminated by three claws. In Corycceus gcrmanus there is only one recurved nail. The four pairs of thoracal feet are no doubt powerful natatory organs, as they are, especially in the male, very broad and covered with long hairs. The fifth pair, a rudiment of which is to be found in Corycceus germanus, could not be observed here.

The thorax ends in the female with a very sharp and slender spine, which is not so strongly developed in the male. The abdomen is reduced in Corycceus to two joints, which in our case are even not clearly to be distinguished, though I think that in the female the first abdominal segment ends behiud the genital opening (fig. $1, s p$.), but in the nale is inseparably connected with the last one. The furca is terminated by two large and two small spines. As can be seeu from our pictures, the shape of the abdominal segment is very different in both sexes; in the female it is swollen up nearly square, and has some small spines on the angle, which is formed at its inferior frontal side. In the specimen I hnve drawn, some oval spermatozoa were attached to the vulva (fig. $1, s p$.). In the male this abdomiual segment is very different; it is more in continuance with the thoracal part of the body, and has no prominent angle at its underside. I could not find the genital opeuing in the male, which in the female is at the upper surface of the segment.

From the species hitherto known, Corycceus megalops differs especially by the pectoral process, by the want of the last and fitth pairs of thoracal feet, and by the union of the two abdominal segments. It will always be a curious fact that in this species the outlines of the cephalothorax have given way so far as to form a long process to receive the immensely increased eyes. Length of female, $0.875 \mathrm{~mm}$., width $0.350 \mathrm{~mm}$.

The species was in considerable quantity in the surface-water for two days, but since that time has never been seen again.

\section{Corycarus limbatus, n. sp. (Pl. XLIX. figs. 18-22).}

Length, 1-16th of an inch (1.55 mm.). Body slender; posterior thoracic spines moderately long, reaching to about the middle of the first abdominal segment, which is about three times as long as the second; caudal stylets slender, about eight times as long as broad, not divergent. Anterior antennæ short; posterior slender, the terminal claw in the male (fig. 19) long, slender, and falcate; inner margin of the second joint bordered with a pellucid and very finely pectinated lamina, which is best developed on the distal half; posterior foot-jaw (fig. 20) rather small, with a flexuous terminal claw. The marginal spines of the swimming feet (fig. 21) are lancet-shaped, with delicately pectinated margins, and the usually vacant interspinous spaces are occupied by supplementary spines $(a, a)$, which, however, are not free, but anchylosed by the inner edge with the limb. Eyes contiguous, situated immediately on the front of the head.

This species was noticed only in one gathering from the tropical Atlantic, in lat. $12^{\circ} 16^{\prime} \mathrm{S}$., long $13^{\circ} 44^{\prime} \mathrm{W}$. Only one or two specimens were seen, but the characters are amply sufficient to distinguish them from any described form. 
4. Corycceus venustus, Dana (Pl. LIV. figs. 8-10).

Coryceeus venustus, Dana, Crust. U. S. Expl. Exped. (1852), p. 1222, pl. lxxxvi. fig. 4, a-d.

" huxleyi, Lubbock, On some Oceanic Entomostraca, \&c., Trans. Linn. Soc, vol. xxiii. p. 182 , pl. xxix. figs. 8,9 .

Length, 1-12th of an inch $(2 \cdot 1 \mathrm{~mm}$.). Cephalothorax broad and scarcely narrower behind than in front; lateral processes of the third segment long, acute, and somewhat spreading; abdomen constricted at the base, and only half as long as the cephalothorax; caudal segments (fig. 10) generally more or less divergent, and equal to about half or three-quarters of the length of the abdomen ; terminal setæ three, the innermost flexuous, slender, considerably longer than the furca, the second about half as long, stouter, and rigid; outermost still shorter and hair-like ; a small marginal seta slightly removed from the apex. Terminal claws of the posterior antennæ (fig. 9) reaching not much beyond the middle of the hand, strongly hooked at the apex, and having a small hooked marginal spine at their attachment to the last joint of the limb.

The generally smaller size of the animal, the shorter and stouter caudal segments, the comparatively small and very strongly falcate claws of the posterior antennæ, are the characters which chiefly distinguish this species from Corycaus varius. The following list of localities includes all of which I have record, but the species certainly occurred in some others, of which I have no note, owing to my failure at first to recognise it as a distinct specific type.

Habitat.-Between Sydney and Wellington; between Api and Cape York; in five gatherings from the Philippine Islands; in lat. $3^{\circ} 10^{\prime} \mathrm{N}$., long. $14^{\circ} 51^{\prime} \mathrm{W}$. (Station 348); and in lat. $26^{\circ} 21^{\prime} \mathrm{N}$., long. $33^{\circ} 37^{\prime} \mathrm{W}$. (Station 353 ).

5. Corycceus speciosus, Dana (Pl. XLVI. figs. 5, 6).

Corycceus speciosus, Dana, Crust. U. S. Expl. Exped. (1852), p. 1220, pl. Lxxxvi. fig. 1, $a-d$.

Length, 1-10th of an inch $(2.55 \mathrm{~mm}$.). Animal elongated and slender, forehead narrow and rounded; thorax slightly constricted in front and wider behind, spines directed straight backward, and reaching as far as the hinder edge of the first abdominal segment; caudal stylets divergent, as long as the abdomen, and excessively slender. Anterior antennæ clothed with numerous setæ, most of which are at least twice as long as the limb itself. Eyes large, remote, situated near the sides of the head.

Corycceus speciosus was found in the tropical Atlantic, in lat. $1^{\circ} 47^{\prime} \mathrm{N}$, long. $24^{\circ} 26^{\prime} \mathrm{W}$. (Station 106). Dana's specimens (two only) were taken not far from the same place, and though the description gives the anterior antennæ as seven-jointed, I do not doubt that the same species is meant. 
6. Corycceus obtusus, Dana (Pl. XLVI. figs. 7-9).

Coryccus obtusus, Dana, Crust. U. S. Expl. Exped. (1852), p. 1214, pl. lxxxv. fig. 6.

? " anglicus, Jubbock, Ann. and Mag. Nat. Hist., vol. xx. (1857), pl. xi. figs. 14-17; Bıady, Monog. Brit. Copep., vol, iii. p. 34 pl. lxxxi. figs. 16-19, pl. lxxxiii. figs. 11-15, pl. lxxxiv. figs. 10-14.

Length, 1-29th of an inch $(87 \mathrm{~mm}$.). Animal rather robust, broadly rounded in front; posterior thoracic spines rather short and stout, about one-third the length of the first abdominal segment, which is at least twice as long as the second, and bears at the antero-ventral angle a small projecting spine; caudal stylets as long as the preceding segment, and not divergent; setæ about half as long as the abdomen. Anterior antennæ clothed with setæ, none of which are much more than half the length of the limb. Lenses large, situated near the sides of the head. The colour of the animal is a beautiful sea-green, the ocular stylets a much deeper shade of the same.

A few specimens of this extremely pretty little species were taken in the Inland Sea of Japan. Having been mounted on the spot, the colour of some of them was beautifully preserved. It is the only species, excepting Coryccus anglicus, in which I have seen the peculiar little spine of the first abdominal segment, and this character, together with the small size, seems to identify it unmistakably with Coryccus obtusus, Dana,

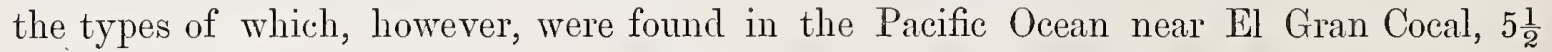
degrees south of the equator. A single specimen was noticed also in a mounting of specimens from lat. $36^{\circ} 44^{\prime}$ S., long. $46^{\circ} 16^{\prime} \mathrm{W}$. (Station 325). I am unable to detect any material difference between this species and Corycaus anglicus, Lubbock.

\author{
Copilia, Dana. \\ Copilia, Dana, Proc. Amer. Acad. Sci., 1849.
}

Body somewhat depressed, broadly quadrate in front, and bearing at each angle a prominent simple corneal lens (anterior eye); abdomen much attenuated, five-jointed. Anterior antennæ (Pl. LIII. fig. 3) short, six-jointed (?); posterior very large, strongly prehensile, and terminating in a long, curved claw. Mandibles (fig. 6) short, truncated, destitute of a palp, the broad distal extremity finely denticulated and produced at the inner aspect into a slender falciform process; maxillæ (? fig. 7) slender, deeply divided at the apex into three digitiform segments; anterior and posterior foot-jaws (figs. 8, 9) very small, simple, and terminating in slender prehensile claws. Four pairs of swimming feet, having both branches three-jointed, except the fourth, where the inner branch consists of only one joint. Fifth pair one-jointed, rudimentary. Pigment bodies of the posterior eyes distant, and bent into an angular form. 


\author{
Copilia mirabilis, Dana (Pl. LIII. figs. 1-11). \\ Copitia mirabilis, Dana, Crust. U. S. Expl. Exped. (1852), p. 1232, pl. lxxx. fig. 14, a-g. \\ , denticulata (?), Claus, Die frei lebenden Copepoden, p. 161, pl. xxv. figs. 14-20.
}

Length, 15-100ths of an inch $(3.6 \mathrm{~mm}$.). The first cephalothoracic segment is quadrangular, much broader than, and as long as, the rest of the body, exclusive of the caudal stylets; the last two thoracic segments are much smaller than the rest and are prolonged on the dorsal aspect into a triangular median spine, and the posterior borders of the abdominal segments are denticulated; the last abdominal segment is as long as the preceding five, and somewhat dilated at the distal extremity; the caudal stylets excessively long and slender, almost linear, divergent, about half as long as the body of the animal, and hearing a few very short terminal setæ. Anterior antennæ (fig. 3) six-jointed, small, rather sparingly setiferous, and reaching only about half-way to the posterior margin of the first body-segment. Posterior antennæ (figs. 4, 5) very large, reaching to the hinder extremity of the first segment, four-jointed, and terminating in a strong, curved claw, second and third joints each bearing a strong marginal spine; in some examples (? males) this spine is branched in a radiate manner near the base (fig. 5). The swimming feet (fig. 10) are short, the external and internal branches of the first four pairs being three-jointed and equal in length; marginal spines of the external branches obsolete; inner branch of the fourth pair (fig. 11) consisting of one joint only; fifth pair of feet wanting (?), or rudimentary.

Habitat.- - This species occurred very sparingly in several gatherings; except in one instance not more than two or three examples were noticed in the material which passed through my hands from any one locality. The following list includes all the gatherings in which the species occurred :-Off Sibago Island, and in several other gatherings from amongst the Philippine Islands; off the north coast of Papua; off Kandavu, Fiji; between Api and Cape York; near the Ki Islands (Station 181); Zamboanga; in lat. $9^{\circ} 43^{\prime} \mathrm{S}$., long. $13^{\circ} 51^{\prime} \mathrm{W}$. (Station 342 ) ; in lat. $5^{\circ} 28^{\prime} \mathrm{N}$., long. $14^{\circ} 38^{\prime} \mathrm{W}$. (Station 349); and in lat. $10^{\circ} 55^{\prime} \mathrm{N}$., long. $17^{\circ} 46^{\prime} \mathrm{W}$. (Station 352 ). It will be seen from this list that all the localities in which Copilia was captured may be assigned to two widely distant areas, the most important area including Polynesia and the Malay Archipelago; the other the North Atlantic, off the west of Africa. I have not been able to detect any important differences amongst the specimens taken from the various places, but the action of the preservative spirit has in all cases so destroyed or obscured the more delicate internal structures, that I have been obliged to rely upon the observations of previous writers for descriptions of those parts. In other respects, many of the specimens were in good condition, except as to the setæ of the caudal stylets, none of which appear to be perfect. The mouth-organs are extremely minute, and-in spirit-specimens at any rate-difficult of observation, and I am by no means sure that my drawings of those parts 
may not require emendation. In general character, however, it is clear that these organs are very similar to those of such genera as Corycceus and Lichomolgus. As to specific characters, I find nothing to separate the Challenger captures from the form described by Dana as Copitia mirabilis, and it is perhaps doubtful whether either Dana's second species Copilia quadrata, or the Copilia denticulata of Claus, is sufficiently distinct to entitle it to stand as separate species. I have not been able to distinguish certainly the two sexes of this species, though the slight differences observable in the structure of the posterior foot-jaws may possibly be of sexual importance.

\section{Lubbockia, Claus.}

Lubbockia, Claus, Die frei lebenden Copepoden (1863).

Body narrow and elongated; eyes wanting. Anterior antennæ six-jointed ; posterior four-jointed, and armed at the apex with several curved prehensile setæ. Mouthorgans small, very like those of Corycceus; posterior foot-jaws very large, prehensile. First four pairs of feet having both branches three-jointed,- - the internal much the longer; fifth pair rudimentary. Abdomen four-jointed in the female, five-jointed in the male. Ovisac single.

\section{Lubbockia squillimana, Claus (Pl. LIII. figs. 12-16, and Pl. LIV. figs. 1-7).}

Length of female, 1-15th of an inch (1.6 mm.), of male 1-12th of an inch $(2 \cdot 1 \mathrm{~mm}$.). The cephalothorax and abdomen are about equal in length, the latter excessively slender, and separated very distinctly from the thorax; thorax very narrowly ovate, the last segment, in the female, having produced lateral angles, and sharply separated from the rest, lateral angles of the last but one produced on the posterior aspect, so as to form two short spines. Anterior antennæ of the female (Pl. LIII. fig. 12) six-jointed, scarcely one-third as long as the first body segment; posterior (fig. 13) slightly shorter, and clothed with numerous nearly equal hairs; in the male (Pl. LIV. figs. 3, 4) the anterior antenna has several sinall and one very long seta, nearly as long as the entire animal. The posterior foot-jaw of the female (Pl. LIII. fig. 14) is very large, and forms a strongly clawed prehensile organ, the hand armed on its concave edge with four or five very stout triangular spines, the terminal claw longer than the hand, stout and falcate; that of the male (Pl. LIV. fig. 7) is much smaller, and the hand is destitute of spines. The swimming feet (Pl. LIII. fig. 15) have the marginal spines of the outer branch laminar and leaf-like, or lancet-shaped, with very finely serrated edges,-very delicate in structure and pellucid, The fifth foot (fig. 16) consists of a single joint, terminating in two laminated setæ or spines like those of the swimming feet. The abdomen is in the female equal to about two-thirds, and in the male to the entire length of the cephalothorax; it is extremely 
slender, the joints being from twice to thrice or four times as long as broad, the caudal stylets very slender, and bearing four terminal setæ, the longest of which are about twice as long as the furca.

Habitat.-In lat. $6^{\circ} 48^{\prime}$ N., long. $122^{\circ} 25^{\prime}$ E. (Station 200); lat. $40^{\circ} 3^{\prime} \mathrm{S}$, long. $132^{\circ} 58^{\prime} \mathrm{W}$. (Station 288); lat. $9^{\circ} 43^{\prime}$ S., long. $13^{\circ} 51^{\prime} \mathrm{W}$. (Station 342); lat. $12^{\circ} 16^{\prime} \mathrm{S}$, long. $13^{\circ} 44^{\prime} \mathrm{W}$. (Station 341); lat. $5^{\circ} 28^{\prime} \mathrm{N}$, long. $14^{\circ} 38^{\prime} \mathrm{W}$. (Station 349); lat. $9^{\circ} 9^{\prime}$ N., long. $16^{\circ} 41^{\prime} \mathrm{TT}$. (Station 351 ).

All these are Atlantic Stations, and situated either within or near the tropics, but the type specimens described by Dr. Claus were taken in the Mediterranean (Messina), and, so far as appears, are in erery respect similar to those brought home by the Challenger. The male was not seen by Dr. Claus, but I think there can be little doubt that the form figured here in Pl. LIV. figs. 3, 4, is referable to that sex; in all structural details it agrees with the female Lubbockia squillimana, except in the presence of a single very long antennal seta, in the weaker build of the posterior foot-jaw, the somewhat different form of the last two thoracic segments, and the slightly larger size of the animal. Only two examples of the male were found, both from Station 349. From the other Stations only very few specimens have been discovered, not more than about a dozen in all.

\section{Oncaea, Philippi.}

Onccea, Philippi, Wiegmann's Archiv, 1843.

Antaria, Dana, Proc. Amer. Acad. Sci, 1849.

In general appearance much like Corycceus. Corneal lenses (conspicilla) small, situated in the front of the head. Fifth thoracic segment very small, and bearing a pair of very minute rudimentary feet. Abdomen of the male five-, of the female four-jointed, the median joints very small, first joint very large. Anterior antennæ short, six-jointed, posterior, three-jointed, prehensile, the last joint armed with numerous setæ. Swimming feet four pairs; all the branches three-jointed.

The generic name Oncaea, proposed by Philippi, is ignored by Claus on the ground of insufficient description, but Philippi's figures are so characteristic as to leave no doubt, as I think, of the animal to which they are intended to apply; the description also, as far as it goes, is perfectly applicable, though incomplete, owing to the accidental loss of the specimen before the author's observations were finished. On the ground of priority, therefore, it seems right to adhere to the name Onccece.

The genus is a very interesting one, as though agreeing with other Corycæidæ (and especially with Corycous) in the essential characters of mouth-apparatus, as well as in the general appearance of the animal, it differs altogether in the structure of the posterior antennæ, which, though prehensile, are more like those of Cyclops, and of the foot-jaws, which resemble those of some Harpacticidæ; the caudal stylets are very distinctly Cyclo- 
poid in shape. These animals are very widely distributed, and often occur in great numbers, but it seems doubtful whether all those hitherto observed may not fairly be referred to one species. The forms assigned by Dana to three distinct species are very probably founded upon various stages of development of one only.

Oncea obtusa, Dana (Pl. LI. figs. 1-11).

Antaria oltusa, Dana, Crust. U. S. Expl. Exped. (1852), p. 1230, pl. lxxxvi. figs. 13, a-e. " mediterranea(?), Claus, Die frei lebenden Copepoden (1863), p. 159, pl. xxx. figs. $1-i$. Onceea venusta (?), Philippi, Wiegmann's Archiv, 1843, pl. iii. fig. 2.

$" \quad$ pyriformis, Lubbock, On some Oceanic Entomostraca, \&c., Trans. Linn. Soc., rol. xxiii. p. 183, pl. xxix. figs. 24,25 .

Length, 1-20th of an inch $(1.3 \mathrm{~mm}$.). Body constricted at the junction of the thorax and abdomen; conical lenses inconspicuous. Antcrior antennæ (fig. 4) six-jointed, nearly equally thick throughout, not half as long as the first body-segment ; third joint much the longest, and cxceeding in length the last three joints; last joint of the posterior antennæ (fig. 5) smail and armed with two fascicles of curved setæ; basal joint with one apical seta. Mouth-organs minute ; mandibles (fig. 6, $a$ ) armed at the apex with several laciniated tceth; maxilla (fig. $6, b$ ) with six or seven slender spine-like setæ; anterior foot-jaws (fig. 7 ) divided into two stout terminal spine-like processes, which are profusely pectinated on the inner margin, also one slender naked seta; posterior foot-jaw forming a strongly clawed prehensile liand, which in the female (fig. 8) is elongated, tapering, and bears on the inner margin two stout setæ and a series of fine short hairs; terminal claw stout, falciform ; in the male (fig. 9) the hand is broadly ovate, destitute of long marginal setæ, but provided with a continuous series of fine hairs, terminal claw long and rather slender. The swimming feet (figs. 10,11) have their external and internal branches of nearly equal length, the first two joints being in all cases much the shortest; marginal spines long, dagger-shaped, with finely serrated edges. Fifth pair of feet extremely small, consisting of a minute tubercle armed with one or two small apical setæ. First joint of the abdomen in both sexes very large, much longer than all the rest of the abdominal segments put together, and in the male having the posterior angles acutely produced; second, third, and fourth segments of the male extremely short; caudal stylets in both sexes about thrice as long as broad, each armed with three subequal terminal setæ, the longest of which is about half as long as the abdomen, one smaller terminal and one lateral seta. Ovisacs two, borne closely adpressed to the back of the abdomen, and reaching, when the ova are mature, nearly to its extremity.

Habitat.-From the following list of localities it will be seen that Oncaea obtusa may fairly be called a cosmopolitan species-excepting, perhaps, from this statement the colder waters of the extreme north and south temperate zones. The Mediterranean is the most northerly region in which it has yet been observed, and indeed had it extended into the 
North Sea or the North Atlantic, it must bcfore now have been found in some of the numerous collections made in those arcas. In some of the Challenger gatherings it occurred rery abundantly, notably in those from the Australian coasts, and especially in gatherings made at night-time :-Off Cape Howe, Australia (at night); off Port Jackson (night and day); between Sydney and Wellington; off Kandavu, Fiji ; between Api and Cape York; between Arrou and Banda; off north and south of Papua; at several Stations amongst the Philippine Islands; in lat. $13^{\circ} 50^{\prime} \mathrm{S}$., long. $151^{\circ} 49^{\prime}$ E. (Station 181); cast of Japan (Station 237); in lat. $30^{\circ} 22^{\prime}$ N., long. $154^{\circ} 56^{\prime}$ W. (Station 256); in the South Pacific (December 5, 1875); in lat. $42^{\circ} 43^{\prime} \mathrm{S}$., long. $82^{\circ} 11^{\prime} \mathrm{W}$. (Station 302); in lat. $45^{\circ}$ $31^{\prime}$ S., long. $78^{\circ} 9^{\prime} \mathrm{TV}$. (Station 303); in lat. $36^{\circ} 44^{\prime} \mathrm{S}$., long. $46^{\circ} 16^{\prime} \mathrm{W}$. (Station 325); in the South Atlantic, lat. $38^{\circ}$, from March 3 to 5 , 1876 ; in lat. $9^{\circ} 43^{\prime} \mathrm{S}$., long. $13^{\circ}$ $51^{\prime} \mathrm{W}$. (Station 342); in lat. $5^{\circ} 28^{\prime} \mathrm{N}$, long. $1 \cdot 4^{\circ} 38^{\prime} \mathrm{W}$. to lat. $9^{\circ} y^{\prime} \mathrm{N}$., long. $16^{\circ}$ $41^{\prime} \mathrm{W}$. (Stations 349, 350,351), and off St. Vincent, Cape Verde (April 26, 1876).

\section{Pachysoma, Claus.}

\section{Pachysoma punctatum, Claus.}

Pachysoma punctatum, Clans, Die frei lebenden Copepoden (1863), p. 163, pl. xxv. figs, 6--11.

One specimen thus named by Dr. von Willimoes Suhm, was taken off Zamboanga. In its present condition it is incapable of accurate identification, having been mounted for the microscope and a good deal distorted; but so far as I can make out, the name is probably correct.

\section{Saphivina, Thompson.}

Saphirina, Thompson, Zoological Researches, 1829.

Body flattened, ovate or subovate, abdomen of the female usually much narrower than the cephalothorax ${ }^{1}$; last thoracic segment, in the male, rudimentary; fifth pair of feet small, one-jointed. Swimming feet two-branched; botlı branches three-jointed. Anterior antennæ five- or six-jointed, the second joint elongated; posterior pediform, four-jointed, clawed. Caudal stylets laminated. Males often opalinc or iridescent. Unpaired eye, vesiculiform. Pigment-bodies of lateral eyes styliform.

The species belonging to this genus, though occasionally parasitic (as in Salpee), are taken generally by the towing net near the surface of the sea, and a large number have been described from various parts of the world,-notably from the Atlantic, Pacific, and Mediterranean. In many of those points, however, which usually afford the best specific

1 The number of abdominal segments is stated by Dana to be five or six, but the last thoracic segment is counted by this author as belonging to the abdomen.

(ZOOL. CHAL.. EXP.--PART XXIII.-1883.) 
characters, - as, for instance, the mouth-organs and feet,-these so-called species differ from one another very little or not at all, the only distinctions being in the form and proportions of the various parts of the body, and sometimes in the structure of the antennæ. Many of the describer species are doubtless distinct and well marked, but I cannot resist the conclusion that not a few have been founded on variable and uncertain characters, - the form and proportions of the abdomen and caudal stylets, for instance, often varying very considerably amongst specimens which, as it seems to me, ought to be referred to a single species, perhaps at different stages of growth or of slightly different race. Between the two sexes there is usually a marked difference of form and colour, the male being generally of a broadly ovate shape, without any distinct constriction or line of separation between abdomen and thorax, and being, moreover, often highly iridescent or opalescent; the females, on the other hand, are devoid of colour, or nearly so, and the abdomen is generally much narrower than the cephalothorax, and separated from it by a distinct constriction. The abdomen is five-jointed in both sexes; the cephalothorax usually also five-jointed, but occasionally the first segment is incompletely (or altogether) divided so as to form a sixth segment. There may be slight sexual differences in the anterior antennæ, and the posterior antennæ are usually more robust and more strongly armed in the male than in the female. The mouth-organs are small and crowded together, consisting of a stout falciform mandible which has ciliated margins but no teeth; a subquadrate, sparingly setiferous maxilla, and two pairs of foot-jaws,--the anterior quite rudimentary, small, and subtriangular, the posterior stouter and simply unguiculate at the apex. The anterior antennæe are usually short and five- or six-jointed, more or less setiferous, and nearly alike in the two sexes; the posterior are larger, stout, prehensile, and strongly clawed; in the female usually more slender and with weaker armature. The eyes are complex, consisting of a small, median, "unpaired" eye, somewhat vesicular in appearance, and of two much larger "paired" or "lateral" eyes, each of which is composed of an anterior conical lens and a posterior more or less distant vitreous body, with which is connected a long, fusiform, and variously-coloured pigment body.

The nervous system, owing to the considerable size and frequent glassy transparency of the animals, is much more plainly visible than in most Copepoda, and consists of a large central ganglion lying a little behind the eyes, and giving off numerous branches to the limbs, viscera, and tegumentary structures.

The alimentary apparatus—stomach, intestine, and liver-and the generative organs in both sexes occupy a large part of the body-cavity, but call for no special remark here. Indeed in spirit-hardened specimens the internal structure becomes almost totally obscured and unfitted for minute examination. Hackel has proposed to divide the genus Saphirina, into two sub-genera,-Pyromma (or Saphirina proper), and Cyanomma jor Saphividina), the following being the characters on which the separation is based. 
Sub-genus: Prroma (Siphirina). Paired eyes having yellow, red, or brown pigment bodies, with corneal lenses placed in the middle or far back. The two last joints of the posterior antemnæ together shorter than the elongated second joint. Inner branches of the fourth pair of feet well developed, and as large as those of the other feet.

Sub-genus: Cravomma (Saphirinida). Paired eyes having violet, blue, or bluishblack pigment bodies, with corneal lenses placed quite on the front of the head. The two last joints of the posterior antennæ together as long as or longer than the very short second joint. Inner branch of the fourth pair of feet rudimentary, its three joints together scarcely longer than the first two joints of the outer branch.

But these characters, though interesting, do not seem to me by any means of sufficient importance to warrant their being taken as the basis of new sub-genera. They have, in fact, not the slightest correlation, being associated or dissociated in the most variable manner. For instance, while the two species here referred to Dana's Saphirina incequalis and Saphivina ovalis, have the inner branch of the fourth foot short, the eyes frontal, and the pigment bodies blue, Saphirina metallina, with frontal eyes and blue pigment bodies, has the inmer branches of all the feet as long or longer than the outer; these three species, therefore, cannot be assigned to either of the sub-genera proposed by Haeckel. It is curious, too, that amongst the many specimens examined by Haeckel no females of any species were seen.

1. Saphirina ovalis, Dana (Pl. XLVII. figs. 1-12).

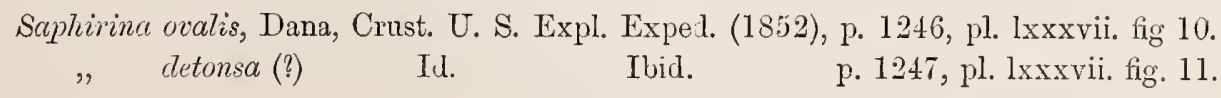

Length, 1-10th of an inch (2.55 mm.) Anterior antennæ (figs. 3, 4) five-jointed, the second joint longer than the following three put together; the whole limb is rather densely setiferous on its upper margin, and in the male (fig. 3) the last three joints bear, instead of setæ, rather stout spine-like appendages. The posterior antennæ (figs. 5, 6) have the last two joints about equal in length to the second joint; in the male they are stouter than in the female, and the second joint is armed on its inner margin with a spine. The swimming feet are short and broad, and those of the fourth pair (fig. 10) have the inner branch very small, not exceeding in length the first two joints of the outer branch. The fifth foot (fig. 11) consists of one joint, about thrice as long as broad, and bearing two unequal apical setæ; the last thoracic somite, to which those feet are attacher, is in the female very small. The second, third, and fourth abdominal segments (fig. 12) are in the female imbricated or lunate at the sides, the first is small, the second much wider, the rest gradually decreasing in width to the last; caudal stylets elongated ovate, more 
than twice as long as broad; two short setæo on the outer margin, and two at the external apical angle; internal apical angle produced into a distinct tooth. Lateral eyes closely approximated, and situated quite on the front of the head; pigment bodies dark blue. In some specimens, as shown in fig. 2 , the integument contains numerous bead-like rows of rounded vesicular or glandular bodies, and these are symmetrically disposed on each side of the body.

Habitat.-T'aken in the towing-net in many places:-Off Kandavu, Fiji; between Api and Cape York; south of Papua; between the Arrou Islands and Banda; at several Stations amongst the Philippine Islands; in lat. $36^{\circ} 32^{\prime} \mathrm{S}$., long. $132^{\circ} 52^{\prime} \mathrm{W}$. (Station 287 ); in lat. $32^{\circ} 2 t^{\prime} \mathrm{S}$., long, $13^{\circ} 5^{\prime} \mathrm{W}$. (Station 335); off St. Vincent, Cape Verde Islands; in lat. $25^{\circ} \mathrm{N}$., long. $33^{\circ} \mathrm{W}$.

Though not unfrequent in the Challenger gatherings, the specimens which came under my notice were, almost without exception, females, and I am therefore doubtful as to the accuracy of some parts of the foregoing description of the male. Having had the opportunity, since the plate was lithographed, of examining further specimens, I am disposed to think that fig. 1 has been drawn from a young individual. Adults are longer, the proportion of length to breadth being as two and a half to one. The margins of the abdominal segments are sometimes very minutely serrated, and the front of the head is always rounded. The lateral angles of the abdominal segments in the male are sometimes minutely mueronate.

2. Saphirina incequalis, Dana (PI. XLVIII. figs. 1-5).

Saphirina incequalis, Dana, Crust. U. S. Expl. Exped. (1852), p. 1244, pl. lxxxvii. fig. 7.

" elegans (o), Lubbock, On some Oceanic Entomostraca collected by Capt. Toynbee, Trans. Linn. Soc., vol. xxiii. p. 12, pl. xxix. figs. 18, 19.

"nitens (o), Lubbock, loc. cit.

Female.-Length, 1-10th of an inch $(2.55 \mathrm{~mm}$.) The third cephalothoracic segment is much narrower (from side to side) than the first two, but the fourth is again wider, and is produced at the angles into two more or less obtusely triangular projections ; ${ }^{1}$ the fifth segment is very short and narrow, scarcely wider than the first abdominal segment. The five abdominal segments are of nearly equal length, but the first is not so wide as either the second or third, and is not "lunate" ; the second, third, and fourth are lunated, and the fifth abruptly truncated. The caudal lamellæ are quite twice as long as broad, ovate, scarcely at all toothed at the inner apical angle, which bears a small seta; there are two apical and two external lateral setæ. The whole length of the abdomen, inclusive of caudal lamellæ, is equal to about half that of the cephalothorax. The first cephalo-

1 In the figure (Pl. XLVIII. fig. 2) the fourth segment is drawn as wide as the third; this is sometimes the case, but in the majority of instances it seems to be as described in the text. 
thoracic segment often shows traces of an imperfect division into two. Anterior antemnæ six-jointed, posterior rather slender, united lengths of the last two joints about equal to the second joint, claw rather long and slender. The eyes are slightly separated, the pigment bodies deep violet in colour. The male is elongate-ovate in shape, the second, third, and fourth joints of the abdomen are lunated, but the angles are neither mucronate nor crenulated.

Habitat.-In lat. $33^{\circ} 31^{\prime}$ S., long. $74^{\circ} 43^{\prime} \mathrm{W}$. (Station 299); lat. $41^{\circ} 54^{\prime}$ S., long. $54^{\circ} 48^{\prime} \mathrm{IV}$. (Station 319) ; lat. $36^{\circ} 9^{\prime}$ S., long. $48^{\circ} 22^{\prime} \mathrm{W}$. (Station 324 ) ; lat. $37^{\circ} 3^{\prime} \mathrm{S}$., long. $44^{\circ} 17^{\prime} \mathrm{W}$. (Station 326) ; lat. $5^{\circ} 28^{\prime} \mathrm{N}$., long. $14^{\circ} 38^{\prime} \mathrm{W}$. (Station 349); lat. $7^{\circ}$ $33^{\prime} \mathrm{N}$., long. $15^{\circ} 16^{\prime} \mathrm{W}$. (Station 350 ) ; lat. $10^{\circ} 55^{\prime} \mathrm{N}$., long. $17^{\circ} 46^{\prime} \mathrm{W}$. (Station 352) ; between Api and. Cape York; off Port Jackson, Australia; off Sibago Island, and at other Stations amongst the Philippine Islands.

3. Saphirina reticulata, n. sp. (Pl. LI. figs. 12-14).

Male.-Length, 1-10th of an inch $(2.55 \mathrm{~mm}$.). Shape broadly ovate, length to breadth as one and three-quarters to one; forehead flattened and distinctly angulated at its junction with the lateral margin, marginal angles of all the segments obtuse; fourth abdominal segment lunated. Caudal lamellæ scarcely twice as long as broad, ovate, inner margin ending in a distinct tooth; setæ equal, short, two apical and two on the external margin. Anterior antennæ short, composed of five nearly equal joints, and bearing only a few very short setæ; posterior longer, finger about as long as the second joint, and having a rather long and slender apical claw. Inner branch of fourth pair of feet half the size of the outer branch. Conspicilla separate. Integument (except the caudal lamellæ) reticulated throughout; reticulations large, irregularly angular, and with beaded sutures. Under a high microscopic power the skin has a finely cross-hatched appearance, reminding one of shagreen or of the grounding of a mezzotint engraving. This peculiar skin-structure I have not seen in any other species. Colour deep brown.

Habitat.-South Atlantic; in lat. $41^{\circ} 54^{\prime}$ S., long. $54^{\circ} 48^{\prime} \mathrm{W}$. (Station 319); and lat. $35^{\circ} 25^{\prime}$ S., long. $23^{\circ} 40^{\prime} \mathrm{W}$. (Station 132 ).

4. Saphivina serrata, n. sp. (Pl. XLIX. figs. 1, 2).

Female.-Length, 1-12th of an inch $(2 \cdot 1 \mathrm{~mm}$.). Cephalothorax five-jointed, very broad and subtruncate in front, obscurely angulated at the union of the anterior and lateral margins, posterior angles rounded off; last segment very small, rounded. Abdomen five-jointed, the segments of nearly equal length, second, third, and fourth lunated and finely serrated (as also the fifth) on the posterior margins. Caudal lamellæ 
elongate-ovate, equal in length to the last three abdominal segments, inner margin ending in a small spine-like seta; two setæo on external margin, and two at apex. Eyes contiguous. In the male the posterior angle of each abdominal segment is produced into a minute tooth; the segments are not marginally serrated, but the last three bear median crests, which are minutely serrated at the extremities.

Habitat.-Off St. Vincent, Cape Verde, April 26, 1876 ; in lat. $13^{\circ} 50^{\prime}$ S., long. $151^{\circ} 49^{\prime}$ E. (Station 181).

This I know only from two or three imperfectly observed specimens, but the characters are so well marked as to leave no doubt of its specific distinctuess.

5. Saphirina opalina, Dana (Pl. XLIX. figs. 3-6).

Saphirina opalina, Dana, Crust. U. S. Expl. Exped. (1852), p. 1254, pl. lxxxviii. fig. 4.

" thomsoni, Lubbock, Trans. Linn. Soc., vol. xxiii. p. 186, pl. xxix. fig. 22, 23.

Female-Anterior antennæ five-jointed, clothed with very short setæ; terminal claw of posterior antenna suddenly much narrower than the joint to which it is attached. Abdomen short and broad, five-jointed, all the joints of about equal length, first and last narrower than the rest, second, third, and fourth, strongly lunated, with acute tips. Caudal lamellæ subquadrangular, about as long as broad, internal apical angle produced into a large triangular spine, distal margin three or four times sinuated, with sharp points of separation. Inner branch of the fourth pair of feet half as long as the outer branch.

Habitat.-Both specimens figured in the plate were taken amongst the Philippine Islands; Professor Dana's and Sir John Lubbock's were from the tropical Atlantic.

Judging from the peculiarities of the posterior antennæ and caudal lamellæ, there can be no doubt that both the figured specimens belong to the same species; but in the very imperfect separation of the joints of the antennæ and limbs in the smaller specimen, the imperfect subdivision of the first cephalothoracic segment, and still more in the presence of only four (instead of five) abdominal rings, I am disposed to think we have indications of an earlier stage of growth. It is probable also that the example described by Dana-having the body composed only of eight joints-was not fully grown. The thorax of the larger specimen was lost in the process of dissection, and thus escaped observation, and the caudal setæ were broken or imperfect.

The antennæe and abdomen, figured at $4 a$ and $5 a$, seem to be those of a male opalina, and belong to a specimen taken in the same locality as the rest. If the antenna be not malformed, it is a very peculiar one; the difference of the abdominal segments may also be a sexual one. 
6. Saphirina opaca, Lubbock (Pl. XLIX. figs. 14-17).

Saphirina opaca, Lubbock, Trans. Entom. Soc., vol. iv. pl. v. figs. 9-11.

Female.-Length, 1-8th of an inch $(3.1 \mathrm{~mm}$.). Body elongated, about thrice as long as broad; abdomen half as long as cephalothorax, five-jointed, first segment narrow and rounded; second, third, and fourth lunate, fifth truncate, all of about equal length; caudal lamellæ ovate or subquadrangular, about twice as long as broad, equal in length to the last three abdominal segments, inner apical angle produced and acute; cephalothorax six-jointed; first joint short, next four about equal in size, and having rounded margins, sixth very small and rounded. Anterior antennæ (fig. 14) five-jointed, bearing numerous setr, which are much shorter than the limb itself; first joint very long, equal to the other three; fingers of the posterior (fig. 15) antenna shorter than the second joint; claw short. Marginal spines of the swimming feet (fig. 16) very short and wide; branches of the fourth pair equal. Eyes contiguous.

Habitat.-South Atlantic, in lat. $41^{\circ} 54^{\prime}$ S., long. $54^{\circ} 48^{\prime} \mathrm{W}$.

Only a few examples of this species were seen, all females, and though they differ somewhat, especially as to the numbers of thoracic and abdominal segments, from. Sir John Lubbock's specimen, they are in other respects so closely similar that I can scarcely doubt their identity with that form. The caudal lamellæ were seen as above described only in the largest of four specimens. In the rest the conspicuous apical tooth was absent, but its outline was indicated within the true margin, so that I suppose it would have been fully developed after the next moult. The limbs, both antennæ and swimming feet, are all extremely small, very much shorter than in any other species known to me.

\section{Saphinina splendens, Dana (Pl. XLIX. figs 11-13).} Saphivina splendens, Dana, Crust. U. S. Expl. Exped. (1852), p. 1246, pl. lxxxvii. fig. 9.

I have noticed three specimens which, from the shape of the caudal lamellæ, seem to belong to this species; but as the abdomen of the female is only three-jointed (fig. 11), I suppose that they are probably immature animals. The gatherings in which they occurred were got off Port Jackson, and at Station 299, lat. $33^{\circ} 31^{\prime} \mathrm{S}$., long. $74^{\circ} 43^{\prime} \mathrm{W}$.; deptl, 20 fathoms.

The specimens, being mounted for the microscope, were not dissected.

8. Saphirina gemma, Dana (Pl. XLVIII. figs. 6-8, and Pl. L. fig. 18).

Saphivina gemma, Dana, Crust. U. S. Expl. Exped. (1852), p. 1252, pl. lxuxviii. figs. 1, 2.

Female.-Length, 1-8th of an inch $(3.1 \mathrm{~mm}$.). A large species, much narrower and more elongated than any of the preceding; nearly four times as long as broad, with the thorax not much wider than the abdomen; angles of the thoracic segments a little 
produced, the second, third, and fourth abdominal segments lunate, but not very strongly so ; first short, second, third, and fourth longer and nearly equal, fifth about half as long again as the preceding, and sharply truncated; caudal lamellæ subovate, nearly thrice as long as broad, and equal in length to the last two abdominal segments, two short external lateral setæ and two longer ones on the apex. Anterior antennæ (fig. 7) five-jointed, the second joint as long as all the rest together; sctro numerous and short; posterior antennæ (fig. 8) stout, the last two joints only about half as long as the second joint; terminal claws short, branches of the fourth pair of feet equal.

The male is in shape a long oval, about twice and a half as long as broad, and the last two joints of the posterior antennæ are long and slender, equalling in length the second joint.

Habitat.-South Atlantic, Fcbruary 12, 1876 (Station 319); between Sydney and Wellington; off Zamboanga; and in the North Atlantic, April 27, 1876.

My description and drawing of the posterior antcnna of the female differs altogether as regards the length of the "finger" from that given by Dana; but having verified it by the disscetion of two specimens, I am obliged to let it stand; in all other respects Dana's observation agrees with mine, and in the male I find the posterior antenna to be of the slender type. Of course it is possible that I may be wrong in referring the female specimens to Saphirina gemma, but their accurate agreement with the types, except in this one particular, for the present at any rate, prevents my calling them by any other name. From the spirit-specimens I cannot say what the original colour may have been, cxcept that some of the females are very opaque and dark-coloured, while Dana's were colourless. The number observed was altogether very small. The spines of the swimming feet (Pl: XLV. fig. 18) are peculiar, being very short and broad at the base, and strongly divaricate, while one side (especially in the case of the apical spines) merges into a finely serrated basal convexity.

9. Saphirina metallina, Dana (Pl. L. figs. 11-17).

Saphirina metallina, Dana, Crust. U. S. Expl. Exped. (1852), p. 1242, pl. lxxxvii. fig. 5. " cylindrica, Lubbock, On scme Oceanic Entomostraca collected by Capt. Toynbee, Trans. Linn. Soc., vol. xxiii. p. 184, pl. xxix. figs. 13-15.

Female.-Length, 1-11th of an inch $(2 \cdot 3 \mathrm{~mm}$.). Cephalothorax elongated, the last joint much narrower than the rest (one-third to onc-fourth of the width); first segment incompletely divided into two; fourth produced behind into two broadly triangular wings; fifth as long as the preceding, but narrow and rounded at the angles; abdomen five-jointed, narrow, segments nearly equal in length; first very narrow, with rounded angles; second, third, and fourth wider and strongly lunate; fifth truncated, and very finely ciliated on the posterior margin. Caudal lamellæ quadrate, with nearly straight 
sides and abruptly truneated apex, nearly as long as the last three segments; one short seta on external margin, one at the angle, and two much longer at the apex; one small seta also attached to the faee of the lamina, not far from the inner angle. Anterior antenna (fig. 13) six-jointed, setæe numerous and longer than the limb; finger of posterior antenna (fig. 14) equal in length to the second joint; basal joint produeed at the inner distal angle, which is armed with two long but rigid setæ; second joint elongated, slender, its inner border slightly convex and bearing a short, almost laneet-shaped seta near the base; third joint rudimentary, oblique, and bearing two very small setre; last joint very long, slender, and produced into a slightly eurved, awl-shaped apex; its outer margin bears, near the middle, two very minute setæ. Branches of the fourth pair of feet nearly equal in size (fig. 15), marginal spines laneet-shaped and finely serrated ; fifth jair almost obsolete (fig. 16, a,a), consisting of a tuberele with two setæ. Eyes (fig. 17) eoalescent. The shape of the male (fig. 11) is oblong oral, about thrice as long as broad, almost equal in width throughout, and searcely at all tapered either in front or behind; the first four abdominal segments are lunated and very mueh imbrieated.

Habitat.-Lat. $17^{\circ} 54^{\prime} \mathrm{N}$, long. $117^{\circ} 14^{\prime}$ E. (Station 206) ; lat. $3^{\circ} 10^{\prime} \mathrm{N}$, long. $14^{\circ} 51^{\prime} \mathrm{W}$. (Station 348); lat. $9^{\circ} 9^{\prime} \mathrm{N}$., long. $16^{\circ} 41^{\prime} \mathrm{W}$. (Station 351); lat. $5^{\circ} 45^{\prime} \mathrm{S}$, long. $14^{\circ} 25^{\prime} \mathrm{VV}$. (Station 345); off south eoast of Papua; in Mid-Atlantie, August 23. 1873, and in Mid-Pacifie, September 1, 1875.

The charaeters of this speeies are so peculiar as to make it quite wnmistakable amongst the known forms of Saphirina. The quite abnormal posterior antennæ and caudal lamellæ are of themselves suffieient, but the laneet-shaped spines of the swimming feet, and the unusually long setæ of the anterior antennæ are valuable subsidiary characters.

10. Sephirina sinuicauda, 11. sp. (Pl. XLIX. figs. 7-10).

The female has a five-segmented abdomen (fig. 9), the first and last segments being small, with rounded angles; the seeond, third, and fourth lunate; eaudal segments ovate, as long as the last four segments, broad at the base and tapered at the apex; inner angle strongly toothed, and deeply exeavated behind the tooth; setæ very short and slender; posterior antenna slender, finger as long as the second joint; branehes of the fourth pail of feet equal in length; conspieilla contiguous. The male has the abdominal segments (fig. 10) almost straight, and their posterior lateral angles very faintly mucronate; the inner branch of the second (?) swimming foot (fig. S) is armed at the apex with several strong, curved spines, the innermost forming a hook ; eaudal lamellæ almost exactly as in the female.

Two specimens only of this speeies have been observed, botll from the Philippine Islands. The eharaeters of the caudal appendages seem to separate it quite conclusively from any other deseribed speeies, nor have I seen elsewhere in this genus any structure

(ZOOL. CHALI. EXP. - PART XXIII.-1883.) 
like that of the swimming foot figured in the plate. From the similarity of armature, existing in the second foot of some male Harpacticidæ, $\mathbf{I}$ suppose this organ to be also the second swimming foot, but as the peculiarity was not noted until after the separation of limbs from body, I cannot be quite sure.

11. Saphirina angusta, Dana.

Saphirina angusta, Dana, Crust. U. S. Expl. Exped. (1852), p. 1240, pl. lxxxvii. fig. 3.

Two specimens, apparently belonging to this species, from off 'Tristan da Cunha, but too much distorted for description, oceur on a microscopic mounting made on board.

\section{Saphirinella, Claus.}

Saphivinella, Claus, Die frei lebenden Copoden, 1863.

Hyalophyllum, Haeckel, Beiträge zur Kenntniss der Corycæiden, 1864.

Body oval, extremely flattened, quite transparent, colourless or slightly opalescent. Body-segments like those of the male Saphirina, but with a very rudimentary fifth segment and feet. Inner branch of the fourth pair of feet one-jointed; fifth pair simple and bearing two setæ. Mouth-organs distant and rudimentary, except the posterior foot-jaws, which are armed with strong prehensile claws. Eyes having a common pigment mass with lateral and median lenses, sometimes a small unpaired eye-spot connected with the pigment body. No corneal lenses (conspicilla); caudal stylets very long and s ender, linear.

Of this genus very few specimens came under my notice, and these were generally more or less damaged, so that I have not had the opportunity of dissecting the animal very minutely. On this account I have preferred to borrow the generic definition given above from the work of Dr. Claus on the Copepod-fauna of Nice, a memoir in which the characters of this genus and its relation to Haeckel's Hyalophyllum are discussed at considerable length. Dr. Claus concludes that the two genera are identical, and in this conclusion I entirely agree. The specimens observed in the Challenger gatherings appear all to belong to the same species, Saphivina stylifera, Lubbock; but another species very closely resembling it is admitted by Haeckel and Claus,--Saphirina vitrea (Hyalophyllum vitreum, Haeckel).

Saphivinella stylifera (Lubbock), (Pl. XLVII. figs. 13-16, and Pl. XLVIII. figs. 9-13).

Saphirina stylifera, Lubbock, Trans. Entom. Soc., vol. iv. (1856), p. 28, pl. iv. figs. 9, 10.

Saphirinella mediterranea, Claus, Die frei lebenden Copepoden (1863), p. 154, pl. xxv. fig. 12. " stylifera, Claus, Die Copepoden-fauna von Nizza (1866), p. 17, pl. i. figs. 13, 14.

Hyalophylllum pellucidum, Hæckel, Beiträge zur Kenntniss der Corycæiden (1864), p. 63, pl. i. figs, 1-6, and pl. iii. figs. 31-39.

Male.-Length, 22-100ths of an inch $(5.5 \mathrm{~mm}$.). Outline of the body broadly ovate. 
Forehead truncated, broad, and enıarginate in the middle, posterior extremity narrow, but only slightly tapered. Anterior antennæ(Pl. XLVIII. fig. 10) six-jointed, ${ }^{1}$ slender, bearing a few long and slender setæ on the margin and apex; posterior antennæ longer than the anterior, four-jointed, and rery slender; first, second, and fourth joints nearly equal in length, third rather shorter, almost devoid of setr, except that the third joint has three on the niargin, the first and second each one, and the last three at the apex ; second foot-jaw three-jointed, having a strongly falcate terminal joint; inner margin of second joint having a boss-like dilatation near the apex (fig. 13); anterior foot-jaw (Pl. XLVII. fig. 13) rudimentary. The head and first three thoracic segments usually have a single large oil globule situated near the lateral margin, and the three thoracic segments have likewise each a similar globule in the middle line of the body. The caudal stylets are long, linear, and closely adpressed (Pl. XLVIII. fig. 9, and Pl. XLVII. fig. 14), bearing a very short seta beyond the middle of the outer margin, and two small thorn-like apical setæ. The nervous system (Pl. XLVII. fig. 16) may be seen with great distinctness in the pellucid body of the animal, and consists of a ganglionic central (brain) mass, in which is embedded a pigmented eye-spot; from this centre are given off in all directions numerous nervebranches, the most conspicuous of these being supplied to the eyes, antennæ, and feet. The genital system (fig. 15) is also very conspicuous, the testis showing as a long fusiform organ on each side, connected by a broad vas deferens with the receptaculum seminis, which opens into a cloacal pouch.

Habitat.-The gatherings in which this interesting species occurred were from off Kandavu, Fiji ; from the North Atlantic, in lat. $5^{\circ} 28^{\prime} \mathrm{N}$., long. $14^{\circ} 38^{\prime} \mathrm{W}$.; from the North Atlantic, near Canary Islands (February 2 and 16, 1873); and April 28, 1876, near the same latitude; South Atlantic, in lat. $35^{\circ} 25^{\prime} \mathrm{S}$., long. $23^{\circ} 40^{\prime} \mathrm{W}$. (Station 132).

Amongst the distinctive characters insisted on by Haeckel as separating his two species vitreum and pellucidum, one from the other, are the numbers of joints of the anterior antennæ (four in pellucidum and six in vitreum), and the situation of the thickened portion of the second foot-jaw (at the apex in pellucidum, at the base in vitreum). In the Challenger specimens I bave found the anterior antenna always six-jointed, except indeed in some instances where the joints could not be very distinctly seen, and where perhaps the limb might have been supposed to be four-jointed; closer observation, however, seemed to reveal, though not very plainly, six joints. As to the structure of the second foot-jaw, I have seen no instance of the basal thickening; so that in these specimens the antennal characters of vitreum (according to Hackel) go with the jaw characters of pellucidum. Claus, however, seems to have observed both species, and endorses the characters given by Haeckel. The female is unknown.

1 The antenna is shown in Plate XLVIII. fig. 10, as having seven joints: this is incorrect; the basal joint should be removed. 
Section III. S I P н O N O S T O M A, Thorell.

Family I. Caligina.

Lepeopltheirus, Nordmann.

Lepeopltheirus, Nordmann, Mikr. Beit.

Fourth pair of feet slender, of only one braneh, and serving the animal for walking. Thorax exhibiting only two distinet artieulations. Frontal plates destitute of suckingdises or lunules on their under surfaee (Baird).

\section{Lepeophtheirus sulmi, n. sp. (Pl. LV. fig. 2).}

Length, 16-100ths of an ineh $(4 \mathrm{~mm}$.). Cephalothorax about twice as long as the rest of the animal, seareely longer than broad, and not mueh narrowed in front; frontal region not emarginate in the middle. Antennæ short, first joint of the anterior pair stout and densely setose towards the anterior margin, second joint bearing several short setæ at the extremity; posterior pair direeted backwards and having the last joint abruptly hooked at the apex. Furcula deeply cleft, segments slender and eurved. Fourth pair of feet reaching to the distal extremity of the genital segment, long, flexmous, and slender, fourjointed, armed with two small lateral and three apieal spines, one of which is very long and eurved. Genital segment mueh broader than long, armed with a small spine at each posterior angle. Last abdominal segnent and caudal stylets about equal in length, and together equalling only about one-half the genital ring.

The segment to whieh the third pair of feet is attached is rounded and squamous, and has a small spine at the base of eaeh pair of feet. Between the rostrum and the base of the first foot-jaw, on eaeh side, is a small forked appendage (fig. 2, a), in shape very much like the "fureula,"-apparently homologous with the "palp" of some authors, but which I cannot perceive to have any organie conneetion with either foot-jaw or rostrum. Nearer the margins of the carapaee, outside of the first foot-jaws, are two minute looked appendages (fig. 2, b), whieh enelose in somewhat dilated bases two objects which have the appearance of very small sueking discs.

Found on a Scarus taken at St. Vincent, Cape Verde, July 1873.

\section{Echthrogaleus, Steenstr. and Lutk.}

Echthroyaleus, St. \& Ltk., Snyltekrebs og Lernæer, 1861.

Dinematura, M.-Edw., Dana, not of Latreille nor Kröyer.

First two body segments coalescent; genital segment broad and that (never long or slerder), and deeply emarginate behind; dorsal laminæ large, and covering half of the 
genital ring; tail unjointed and hidden under the genital ring; fourth pair of feet small, the basal joint not aleform ; first three pairs of feet rudimentary, consisting only of plumose setæ.

\section{Echthrogaleus affinis, M.-Edwards.}

A single specimen of this species was found, but the name of the locality has unfortunately been lost.

\section{Pandarus, Leach.}

Body broadest in front. Cephalothorax four-jointed; first segment very large, second short, and having alæform lateral processes; third and fourth simple and bilobate. Abdomen two- or three-jointed, rounded behind; caudal stylets borne on the side of the abdomen, acute, styliform, non-setiferous. Eyes two. Four pairs of swimming feet, all two-branched, the fourth pair rudimentary. Sucking dises two (or three) pairs-two pairs on the sides of the carapace, and one at base of second antenna (Dana).

1. Pandarus cranchii, Leach (fide Steenstrup and Lütken).

$$
\begin{aligned}
& \text { Pandarus crunclizi, Steenstr. and Ltk., Bilrag til Kundskab om det aabue IIavs Snyltekrebs og } \\
& \text { Lernæer, p. 50, Tab. xi. fig. 22. } \\
& \text { " carcharice (Leach?), Burmeister, Neuen oder weniger bekannten Schmarotzerkrebse, } \\
& \text { p. 273, pl. xxv. } \\
& \text { ? " armatus, Heller, Crustacea Novara Exped., p. 202, Tab. xix. fig. } 4 . \\
& \text { ? " " concinnus, Dana, Crust. U. S. Expl. Exped. (1852), p. 1366, pl. xev. fig. } 1 .
\end{aligned}
$$

A large number of specimens found parasitic on Carcharias brachynus, between Papua and Japan, and off the Kermadec Islands.

The form and proportions of this animal seem to be subject to a good deal of variation, dependent perhaps upon the age of the specimen; the length and shape of the posterior abdominal segment and caudal stylets are especially variable; and amongst the Challenger specimens are many which I cannot distinguish from Dana's Pandarus concinnus. These, however, are lighter in colour, without the conspicuous brown or black blotches of the typical form, somewhat smaller (?), and altogether so different in appearance under the low magnifying power of a hand lens, that I at first set them aside as belonging to a distinct species. This, however, I believe to have been an error; and as Heller's figures of Pandarus armatus very closely agree with the "concinnus" form, I am disposed to think that this also may fairly be taken as a synonym.

Heller observes that the male of Pandarus armatus is unknown, but that Nogagus 
lattreillii being found in company with it is probably the male-a supposition which is to some extent borne out by anatomical details. It is interesting to note that Nogagus latreillii occurs also abundantly in the Challenger gatherings along with Pandarus cranchii. Dana's specimens were "from the body of a shark taken south of Tongatabu," Heller's from Scyllium africanum at the Cape of Good Hope.

\section{Pandarus satyrus, Dana.}

Pandarus satyrus, Dana, Crust. U. S. Expl. Exped. (1852), p. 1367, pl. xev. fig. 2.

One specimen, apparently referable to this species, was found in company with the preceding off the Kermadec Islands. It comes very near to Heller's Pandarus lugubris.

\section{Pandarus zygana, n. sp. (Pl. LV. fig. 3).}

Length, 27-100ths of an inch (7 mm.). Anterior body-segment shorter than its width, irregularly quadrate in form, flattened in front, constricted behind the antennæ and dilated into two alæform processes behind; posterior margin armed in the middle with a series of six stout spines; second segment forming two large lateral wings; caudal laminæ rather wide, oblique at apex, and armed with three sharp, stout spines-two internal lateral and one apical-reaching slightly beyond the rounded terminal lobe of the abdomen. The anterior part of the body is marked with a deep brown blotch, corering the greater part of the segment except for two small transparent points near the centre; the side wings of the second segment are also deeply blotched, as also are the next segment and the terminal abdominal lobe.

Found in considerable numbers upon a specimen of Zygana malleus taken at St. Vincent, Cape Verde Islands.

Perissopus, Steenstr. and Ltk.

Perissopus, St. and Ltk., Loc. cit., 1861 ; ? Lepidopus, Dana.

Female.-Cephalothorax undivided; abdominal segments free, and bearing four or six dorsal leaflets; genital segment rather large and broad, covering the very short tail ; abdominal feet destitute of plumed setæ, branches of the first and second pair twojointed; for the rest, inarticulate and quite rudimentary. Male unknown.

Perissopus dentatus (Steenstr. and Ltk.).

Perissopus dentatus, St. and Ltk., Bidrag til Kundskab om det aabne Havs Snyltekrebs og Lernæer, p. 53, Tab. xii. fig. 25.

The name of the locality in which this species was taken has been lost. 


\section{Alebion, Kröyer.}

Alebion, Kröyer, Bidrag til Kundskab om Snyltekrebs, 1863.

Rostrum intermediate in form between that of Caligus and Pandarus, provided with large and strong palps. First pair of swimming feet two-branched, branches two-jointed; outer branches of the first, second, and third pairs armed with curiously-formed laminx. Fourth pair rudimentary, two-jointed, one-branched. Carapace produced backwards into two long, narrow processes. Antennal palps, sucking-dises, and furcula wanting.

Alebion carcharice, Kröyer.

Kröyer, Bidrag til Kundskab om Snyltekrebs, p. 165, Taf. xii. fig. 1.

Found on Zygana malleus at St. Vincent, Cape Verde.

\section{Nogagus, Leach.}

This genus differs from Pandarus in that the cephalothoracic segments are destitute (or nearly so) of lateral alæ, and are not bilobate; the abdomen is well developed, and its segments distinct; there is no rounded telson, and the caudal stylets are laminar, terminal, and bear setæ of the true Cyclopoid type.

1. Nogagus grandis, Steenstr. and Ltk.

Nogagus grandis, St. and Stk., Snyltekrebs og Lernæer, p. 45, Pl. x. fig. 19.

One specimen of this fine species. The memorandum of locality lost.

2. Nogagus lunatus, Steenstr. and Ltk.

Nogagus lunatus, ibid. ibidem, p. 49, pl. ix. fig. 17.

From back of Carcharias glaucus, Atlantic, Narch 2, 1876.

3. Nogagus latreillii, Leach (fide Steenstr. and Ltk.).

Nogagus latreillii, ibid. ibidem, p. 44, pl. ix. fig. 18.

On Carcharias brachyurus, between Papua and Japan, and near the Kermadec Islands.

\section{Nogagus curticaudis (Dana).}

Specilligus curticaudis, Dana, Crust. U. S. Expl. Exped., p. 1375, pl. xcv. fig. 6.

On Carcharias brachyurus, between Papua and and Japan.

5. Nogagus validus, Dana.

Nogagus validus, idem. ibidem, p. 1363, pl. xciv. fig. 9.

On Carcharias brachyurus, between Papua and Japan. 
6. Nogagus murrayi, n. sp. (Pl. LV. fig. 1).

Length, 16-100ths of an inch $(4 \mathrm{~mm}$.). Cephalothorax ovate, much longer than broad, and nearly thrice as long as the abdomen; frontal margin rounded, lateral margins somewhat sinuous, posterior angles moderately produced backwards and rounded off. First abdominal (genital) segment about as long as broad, margins round; angles not at all produced nor acute. Two posterior abdominal scgments much broader than long, the last pentagonal in shape, and produced backwards ketween the caudal lamcllæ into two obtuse points; caudal lamellæ about as broad as long, subquadrate, each bearing four finely plumose setæ.

Taken in the open sea off Rio de Janeiro, and in the North Atlantic (about lat. $25^{\circ} \mathrm{N}$.), April 28, 29, 1876. Very similar to Nogagus errans, Kröyer, which, however, differs decidedly in the shape of the last abdominal and two posterior thoracic segments.

\section{Family II. DicheLestide.}

$$
\text { Hessella, }{ }^{1} \text { n. gen. }
$$

Body much elongated, eylindrica!; cephalothorax not much more tumid but longer than the abdomen, which terminates in two blunt adpressed lobes, each bearing three small setæ. Anterior antennæ very small, indistinctly five-jointed (Pl. LV. fig. 10), and densely sctose; posterior (fig. 11) small, but stout and hamate. Four pairs of swimming feet, the branches all biarticulate, first and second pairs (fig. 12) twobranched, third and fourth (fig. 13) one-branched.

\section{Hessella cylindrica, n. sp. (Pl. LV. figs. 9-13).}

One specimen only taken off Zamboanga.

The species most nearly approaching this seems to be Clavella tenuis, Heller, the general characters of some of the appendages being very similar to those of IIessella; but the proportions of head, thorax, and abdonen are widely different, as also are the antennæ. I was unable to find any mouth-organs.

\section{Family III. Chondracanthide..}

\section{Chondracanthus, De la Roche.}

Two pairs of foot-jaws, prehensile, the lhird nearly rudinentary. Appendages of thorax representing the feet, in form digitated, but not articulated, and not setiferous lobes or tubercles, oviferous tubcs very short, broad and Hattened (Baird).

\footnotetext{
1 Named after M. Eessa of Frest, autho: of numerous memoins on l ar wi ic Crusteca.
} 
Chondracconthus (?) macrurus, n. sp. (Pl. LV. figs. 4-8).

Length, 29-100ths of an inch $(7 \cdot 2.5 \mathrm{~mm}$.). Body short and stout; head considerably broader than long, broadly rounded in front, and laving a long and slender alæform process at each side, directed backwards. Anterior antennæ rather large, projecting much beyond the sides of the head, two-jointed, obtuse and quite destitute of setæ. Abdomen stout, as broad or broader than the head, and about twice as long as the cephalothorax, genital segnent short, tail very small and terminating in two minute spines, and reaching about as far backwards as the abdominal lobes. The second cephalothoracic segment has two lateral alæ similar to those of the first segment.

Parasitic on a Macrurus, taken at a deptl of 600 fathoms, off the Kermadec Islands. One specimen only.

This ought probably to be made the type of a new genus, the mouth-organs being apparently quite different from those of Chondracanthus, but my observations of it are so imperfect that it seems best to place it provisionally with Chondracanthus.

\section{Family IT. Leinæid}

\section{Lernæa, Linné.}

Body more or less twisted and outré in appearance. Head furnished with horn-shaped appendages, which are irregularly branched. Ovarian tubes twisted into round masses and placed under the posterior portion of the body. Abdomen of considerable size (Baird).

\section{Lerncea hemiramphi(?), Kröyer.}

Lerncea hemirumphi, Kröyer, Bidrag til Kundskab om Snyltekrebs, p. 318, Tab. xv. fig. 7.

Parasitic on Cavalli taken at St. Vincent, Cape Verde, August 5, 1873.

\section{Lerncea abyssicola, n. sp.}

An intcresting species of Lernaa, which I propose to call Lernoce abyssicola, was observed during the voyage of the Challenger by Dr. v. Willemoes Suhm. The accompanying woodcut is reproduced from his drawing of the living animal, and the following description is taken from his notes.

Lernce, July 23, 1873, 2400 fathoms; Station 89. On a specimen of the curious Lophioid genus Ceratias 1 -an undoubted deep sea form-I discovered a specimen of Lernaca, which differs from all other parasitic Copepoda by its transparency. The head of the animal is a simple thread-like prolongation imbedded in the lateral muscles of tìe fish, and, so far as I was able to trace it, was quite unprovided with differentiated appendages; and I hardly think that they could have got torn off.

${ }_{1}$ The fish here alluded to is described by Sir Wyville Thomson (Voyage of the Challenger, Atlantic, rol. ii. p. 69) as Ceratias uranoscopus, Murray; Dr Günther is of opinion that it is specifically identical with Ceratias holbölli from Greenland.-J. M.

(zOOL. CHALL. EXP.-PART XXIII.-1883.) 
The head is $4.5 \mathrm{~mm}$. long, and the sack-shaped body $9 \mathrm{~mm}$. loug; the latter shows no trace of segmentation or appendages, with the exception of two furcal processes at the end of the body; on the summit of each of these are a few bristles. In the interior of the animal can be distinguished a narrow oesophagus (oe) passing into a wide stomach (st), which shortly becomes constricted into an intestine $(i)$ whose walls are clotbed with extraordinarily developed longitudinal muscles $(m)$ extending

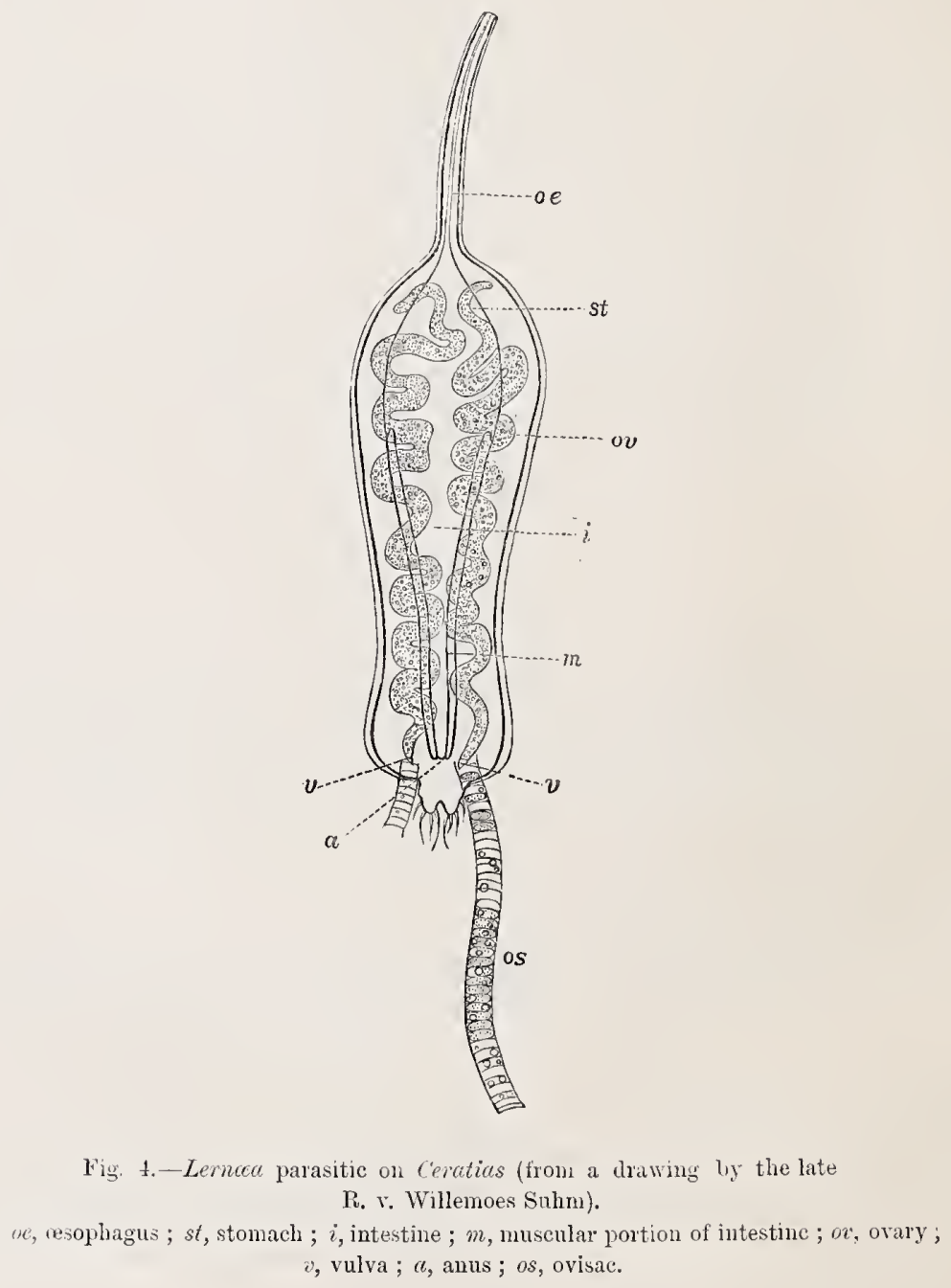

as far as the anus $(a)$; these muscles facilitate the strong sucking novement of the intestinal tract, visible during the life of the animal. In the body cavity are numerous traces of a fat body, and on either side a simple tube-shaped ovary $(o v)$, which opens close to the anus. With this vulva $(v)$ is connected on either side an ovisac (os) containing eggs and large fat globules.

The colour during life was reddish-brown.

My best thanks are due to my friend the Rer. Dr. Norman, for his valuable assistance in the examination and identification of the fish-parasites, and for the opportunity he has kindly afforded me of comparison with specimens in his own collection. 


\section{CONTENTS.}

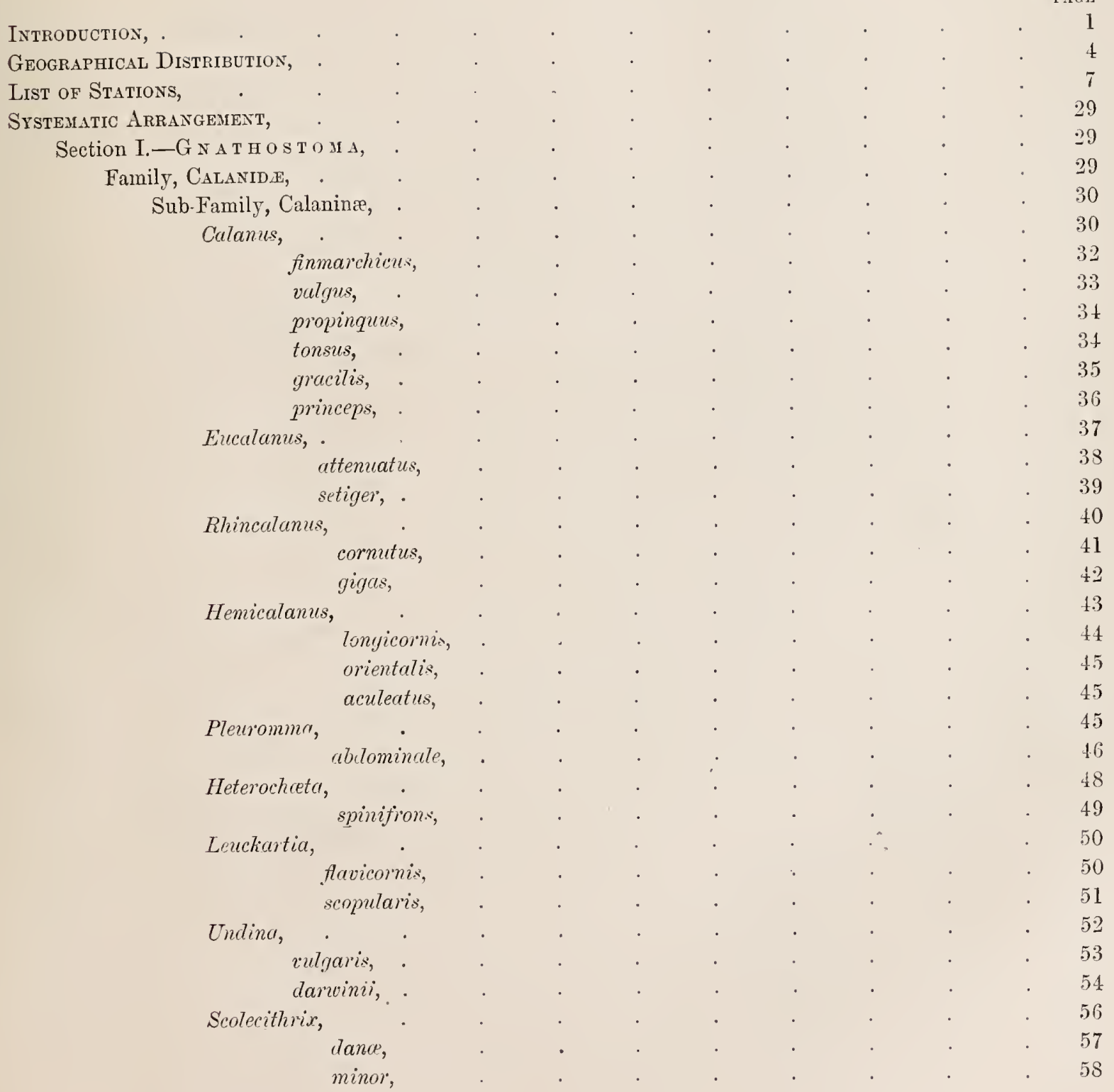




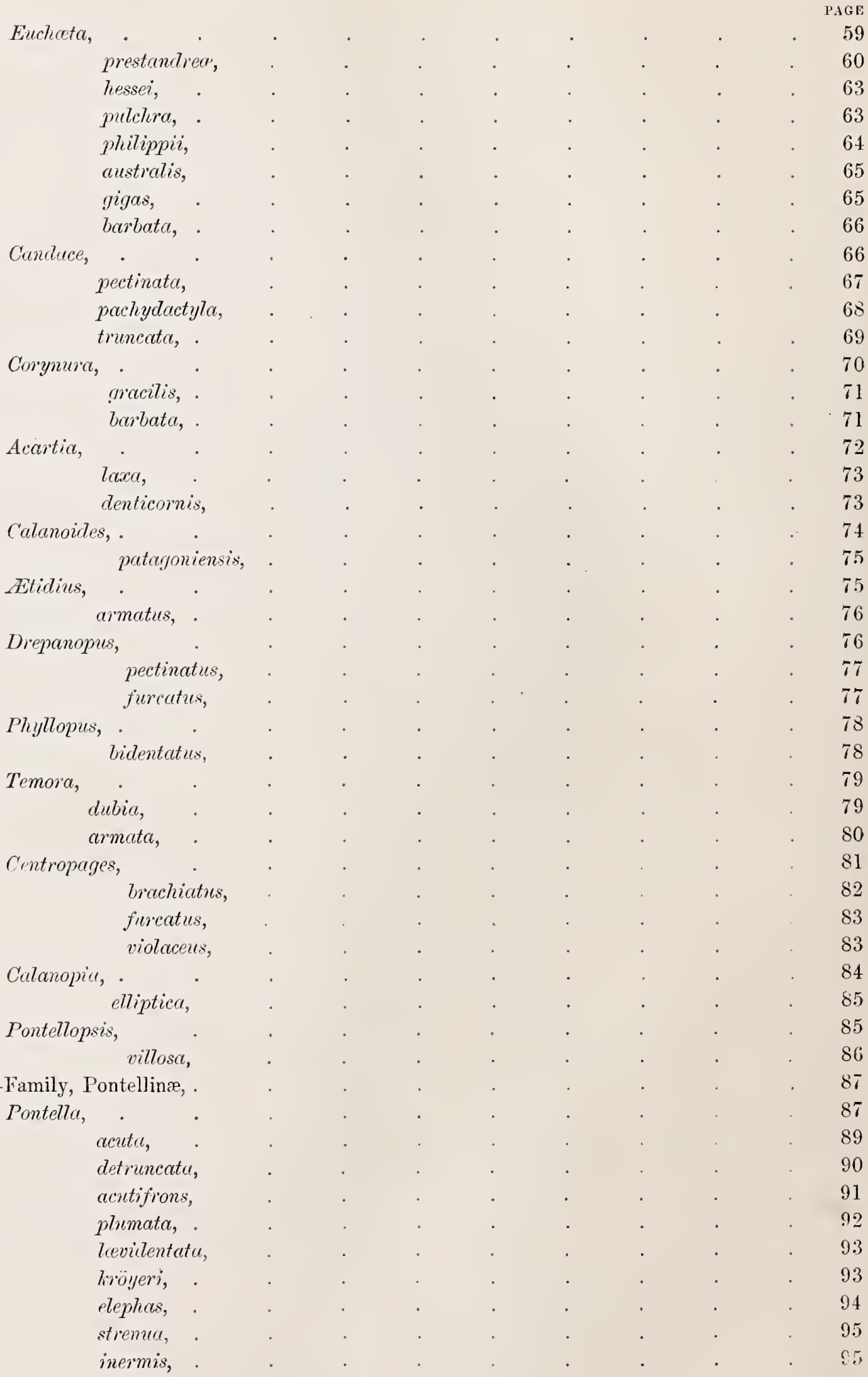


Pontella securifer,

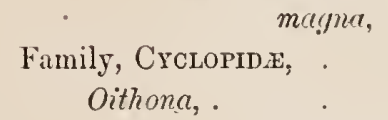

Section II. -P E CILOSTOHA, . . . . . . . .

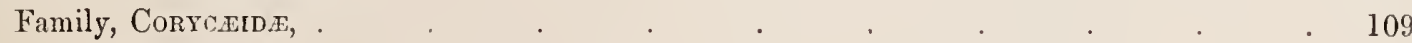

Corycceus,

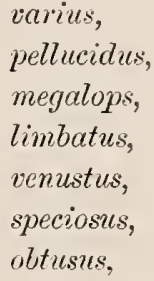




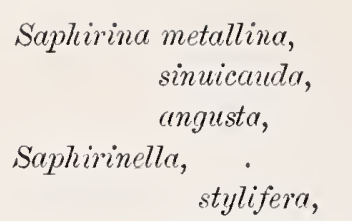

Section III. SIPHON OS TOMA, . Family, Caligina

Lepeotheirus,

Echthrogaleus, .

Pandarus, affinis

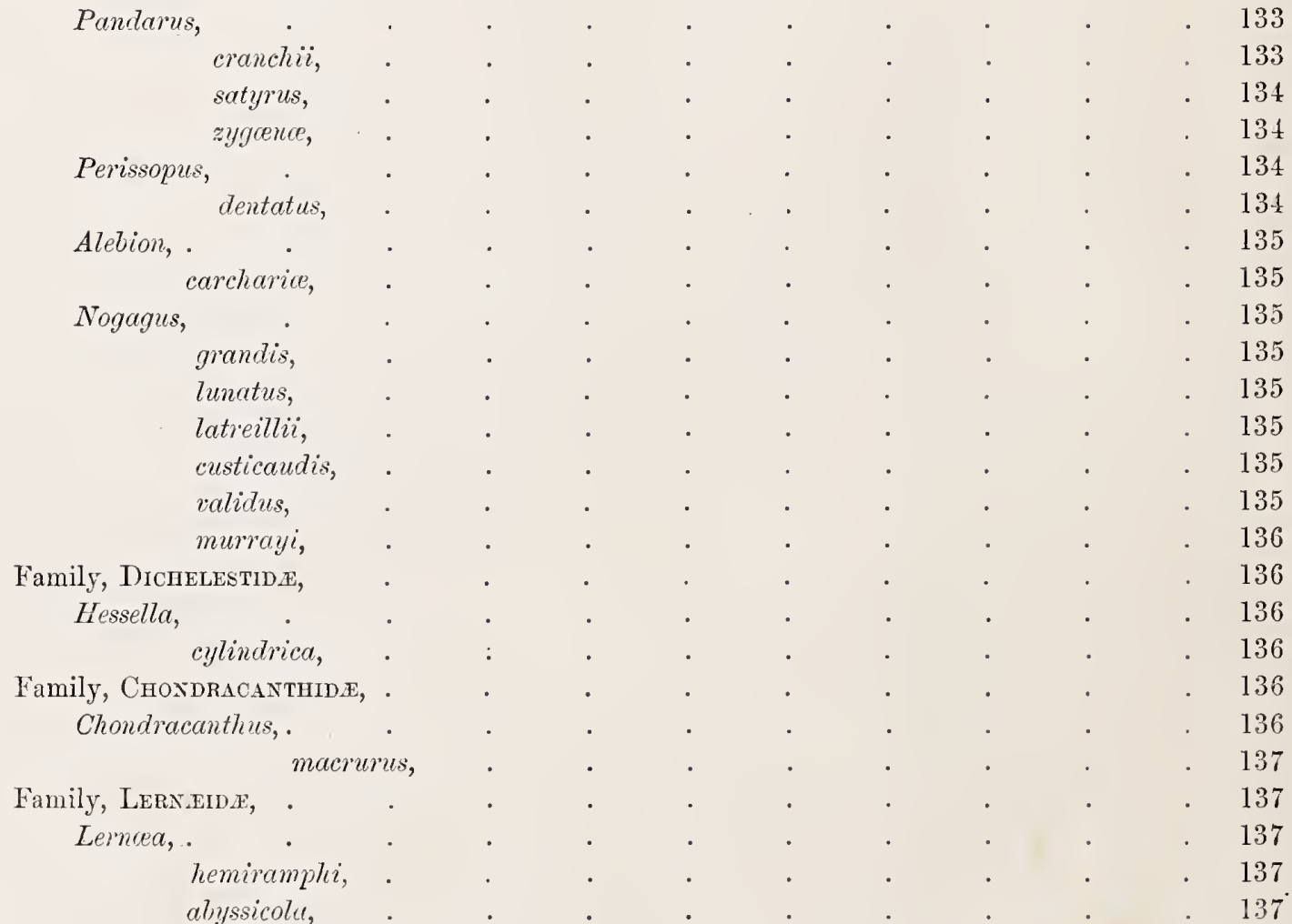

PAGE 
PlA'TE I.

(ZOOL. CHALL. EXP.-PART XXII. - 1883).--Z. 


\section{PLATE I.}

Calanus, finmarchicus (Gïnner).

Fig. 1. Male, seen from the left side, magnified 40 diameters

Fig. 2. Anterior antenna of female.

Fig. 3. Posterior antenna.

Fig. 4. Mandible-palp.

Fig. 5. Mouth with lips.

Fig. 6. Maxilla.

Fig. 7. Posterior foot-jaw of male.

Fig. 8. Posterior foot-jaw of female.

Fig. 9. Foot of fourth pair.

Fig. 10. Fifth pair of feet of male. 

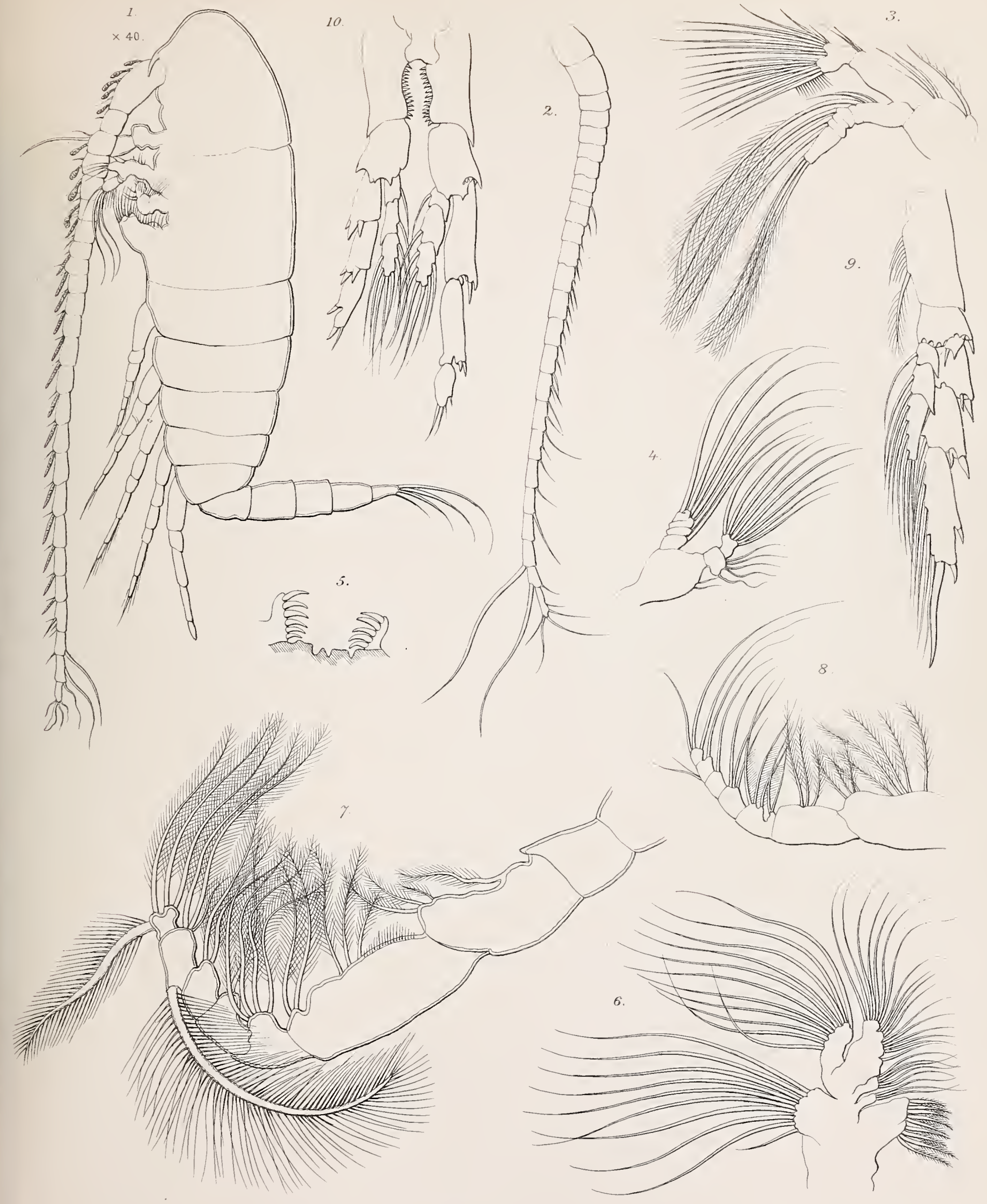

PLATE II. 


\section{PLATE II.}

Figs. 1-7. Calanus propinquus, n. sp.

Fig. 1. Female, seen from right side.

Fig. 2. Dorsal view of the same, both magnified 16 diamcters.

Fig. 3. Anterior antenna.

Fig. 4. Inner branch of posterior antenna.

Fig. 5. Mandible and palp.

Fig. 6. Foot of fifth pair (serratures distorted).

Fig. $6 \propto$. Serratures more highly magnified and in natural position.

Fig. 7. One of the caudal stylets with setæ.

Figs. 8-10. Eucalanus attenuatus, Dana.

Fig. 8. Maxilla.

Fig. 9. Posterior foot-jaw of female.

Fig. 10. Fifth pair of feet of male. 


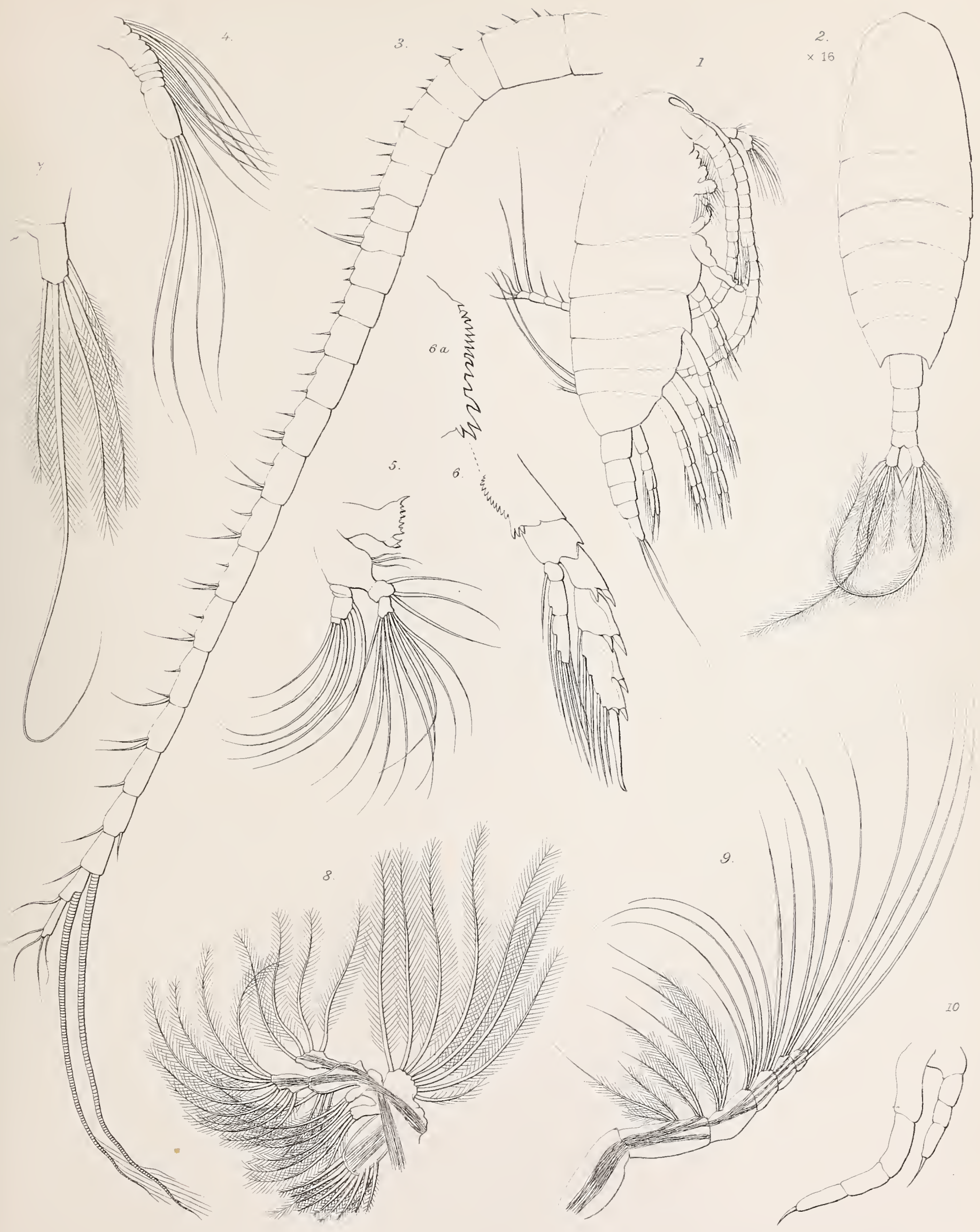

G.S. Brady del. 

PLATE III.

(ZOOL. CHALL. EXP.—PART XXIII,-1883).—Z 


\section{PLATE III.}

Figs. 1-7. Calanus valgus, n. sp.

Fig. 1. Female, seen from right side, magnified 24 diameters.

Fig. 2. Anterior antenna of female (joints of swimming feet not quite correct).

Fig. 3. Mandible and palp.

Fig. 4. Foot of fourth pair.

Fig. 5. Fifth pair of feet of male.

Fig. 6. Right fifth foot of male in flexed position.

Fig. 7. Abdomen of male.

Figs. 8-15. Eucalanus setiger, n. sp.

Fig. 8. Male, seen from left side, magnified 20 diameters.

Fig. 9. Posterior antenna of male.

Fig. 10. Posterior antenna of female.

Fig. 11. Mandible and palp.

Fig. 12. Foot of fourth pair.

Fig. 13. Foot of fifth pair of male.

Fig. 14. Last two thoracic segments of male, seen from above.

Fig. 15. Abdomen of male. 


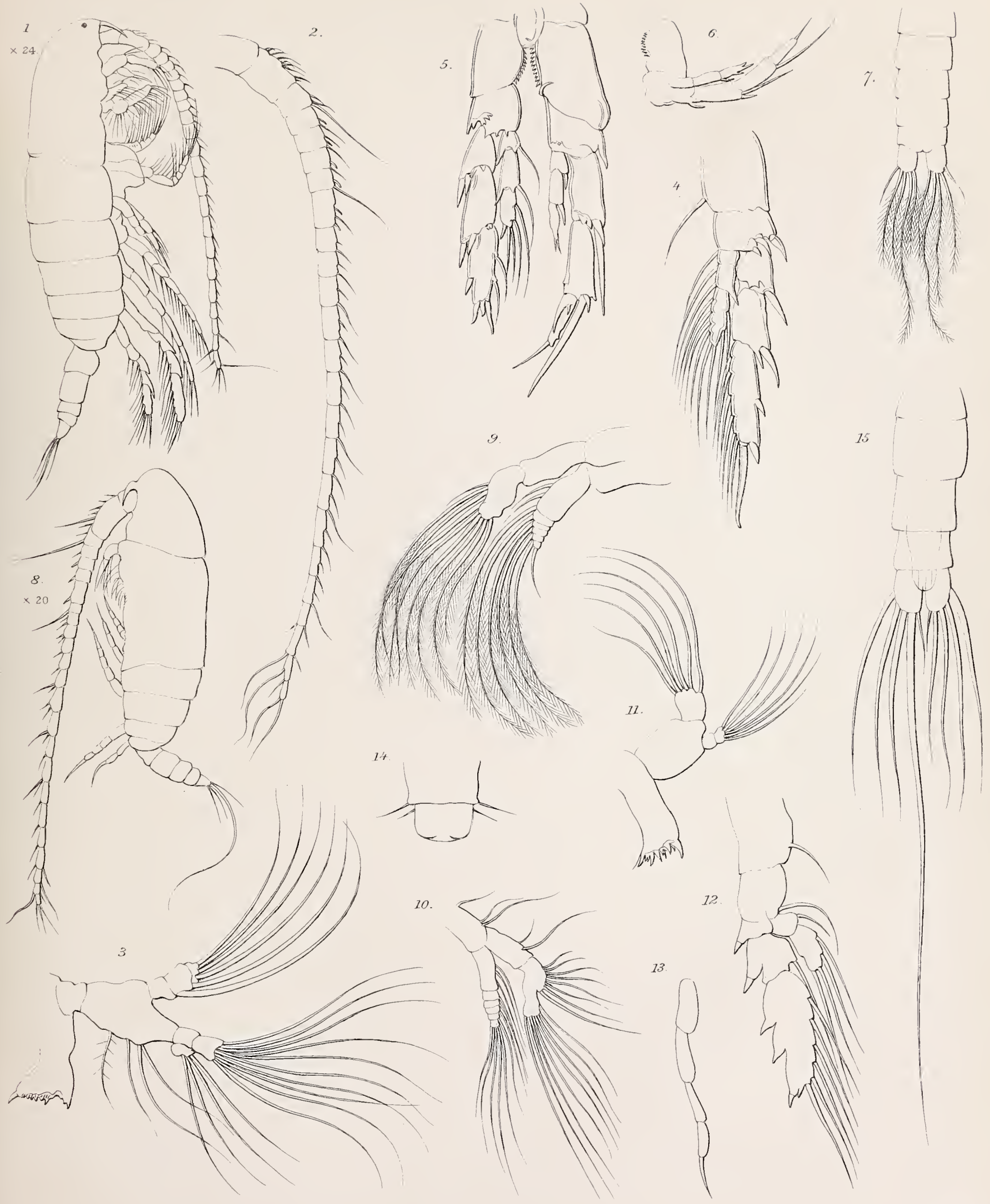



PLATE IV. 


\section{PLATE IV.}

Figs. 1, 2. Drepanopus furcatus, n. gen. and sp.

Fig. 1. Female, seen from right side, magnified 80 diameters.

Fig. 2. Anterior antenna of the same.

Figs. 3-7. Calanus princeps, n. sp.

Fig. 3. Female, natural size.

Fig. 4. Anterior antenna of the same.

Fig. 5. Maxilla.

Fig. 6. Portion of seta of anterior foot-jaw, with marginal hairs.

Fig. 7. One of the swimming feet.

Figs. 8-9. Calanus tonsus, n. sp.

Fig. 8. Anterior antenna.

Fig. 9. Abdomen (female).

Figs. 10-14. Ectinosoma atlanticum (?), Brady and Robertson.

Fig. 10. Female, seen from above, magnified 80 diameters.

Fig. 11. Posterior antenna.

Fig. 12. One of the swimming feet.

Fig. 13. One of the fifth pair of feet.

Fig. 14. Posterior segments of abdomen. 


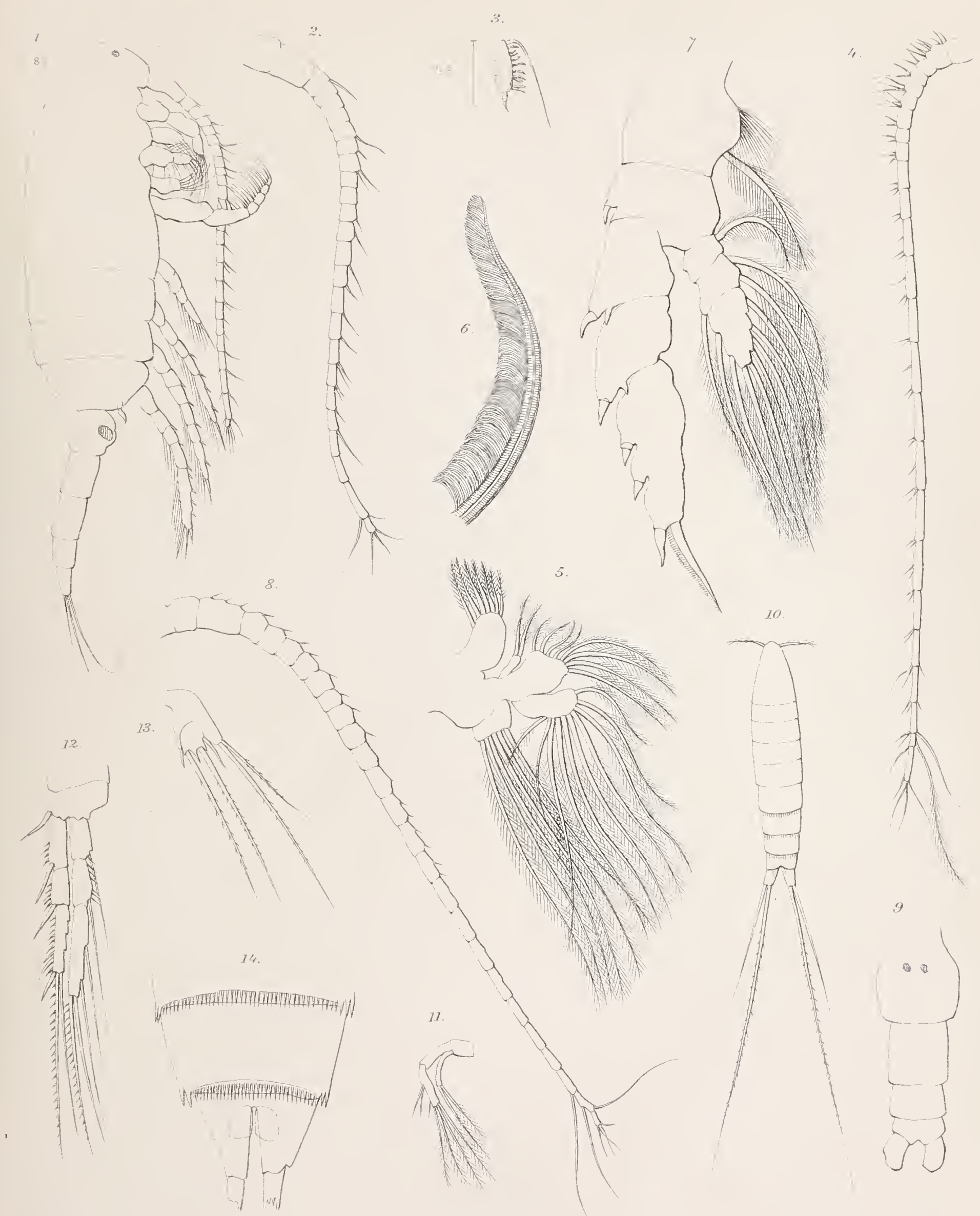





\section{PLATE I.}

(ZOOL. CHALI, EXP.-PART XXIII, - 1883.)-Z. 


\section{PLATE V.}

Figs. 1-6. Calanus gracilis, Dana.

Fig. 1. Female, seen from above, magnified 20 diameters.

Fig. 2. Maxilla.

Fig. 3. Terminal seta of first foot.

Fig. 4. Foot of fourth pair (female).

Fig. 5. Foot of fourth pair (male).

Fig. 6. Right fifth foot of male.

Figs. 7-16. Phyllopus bidentatus, n. gen. and sp.

Fig. 7. Anterior antenna (male?).

Fig. 8. Mandible.

Fig. 9. Maxilla.

Fig. 10. Anterior foot-jaw.

Fig. 11. Posterior foot-jaw.

Fig. 12. Fifth pair of feet (male ?).

Fig. 13. Posterior thoracic angle and lateral view of abdomen.

Fig. 14. Anterior view of abdomen.

Fig. 15. Terminal spines of one of the swimming feet.

Fig. 16. Rostrum. 


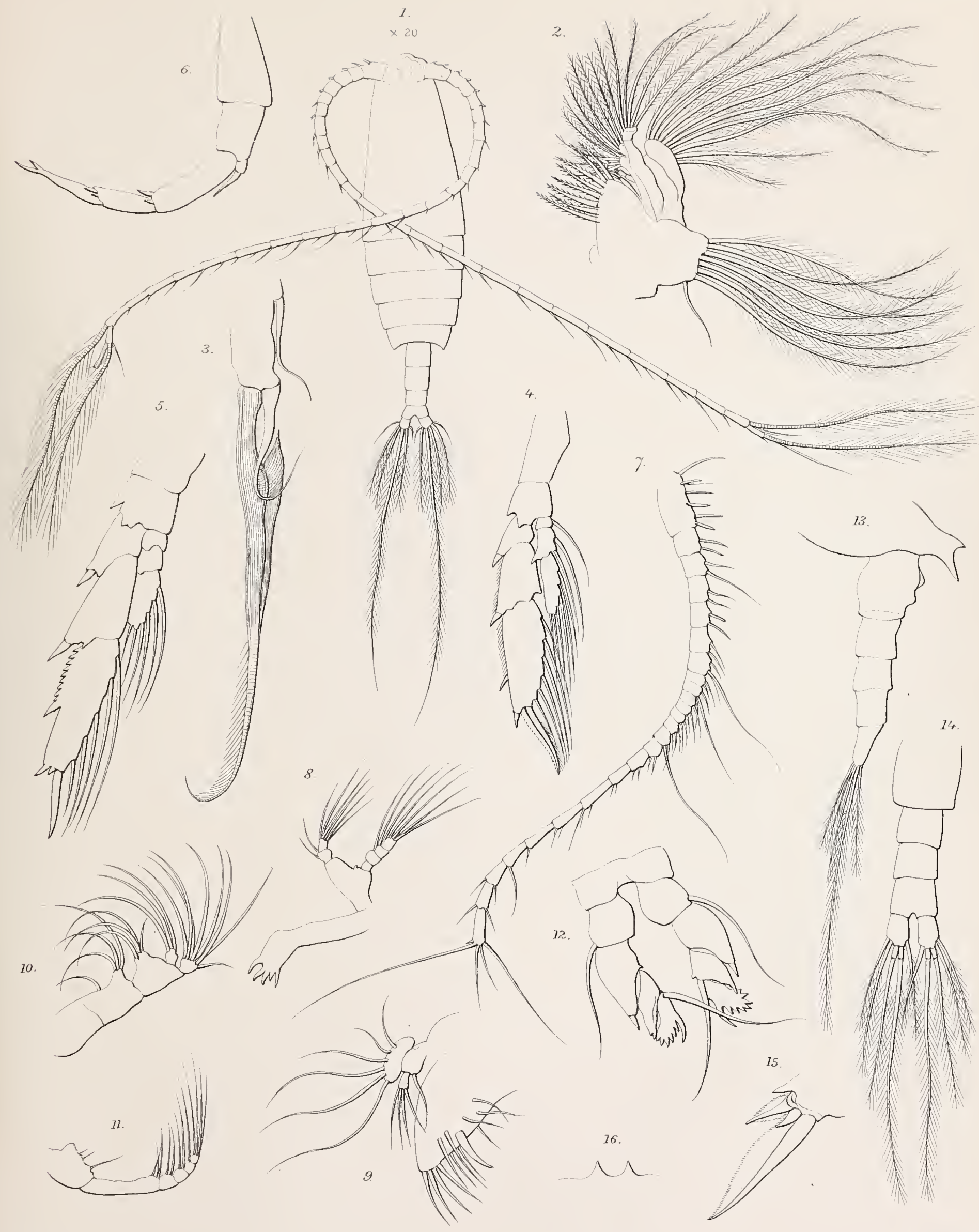



PLATE VI. 


\section{PLATE VI.}

\section{Eucalanus attenuatus, Dana.}

Fig. 1. Female, seen from right side, magnified 32 diameters.

Fig. 2. Head of the same seen from below; $(r)$, rostrum.

Fig. 3. Rostrum.

Fig. 4. Posterior antenna.

Fig. 5. Mandible and palp.

Fig. 6. Anterior foot-jaw.

Fig. 7. Posterior foot-jaw of male.

Fig. 8. One of the swimming feet. 
The voyage of H.M.S"Challenger
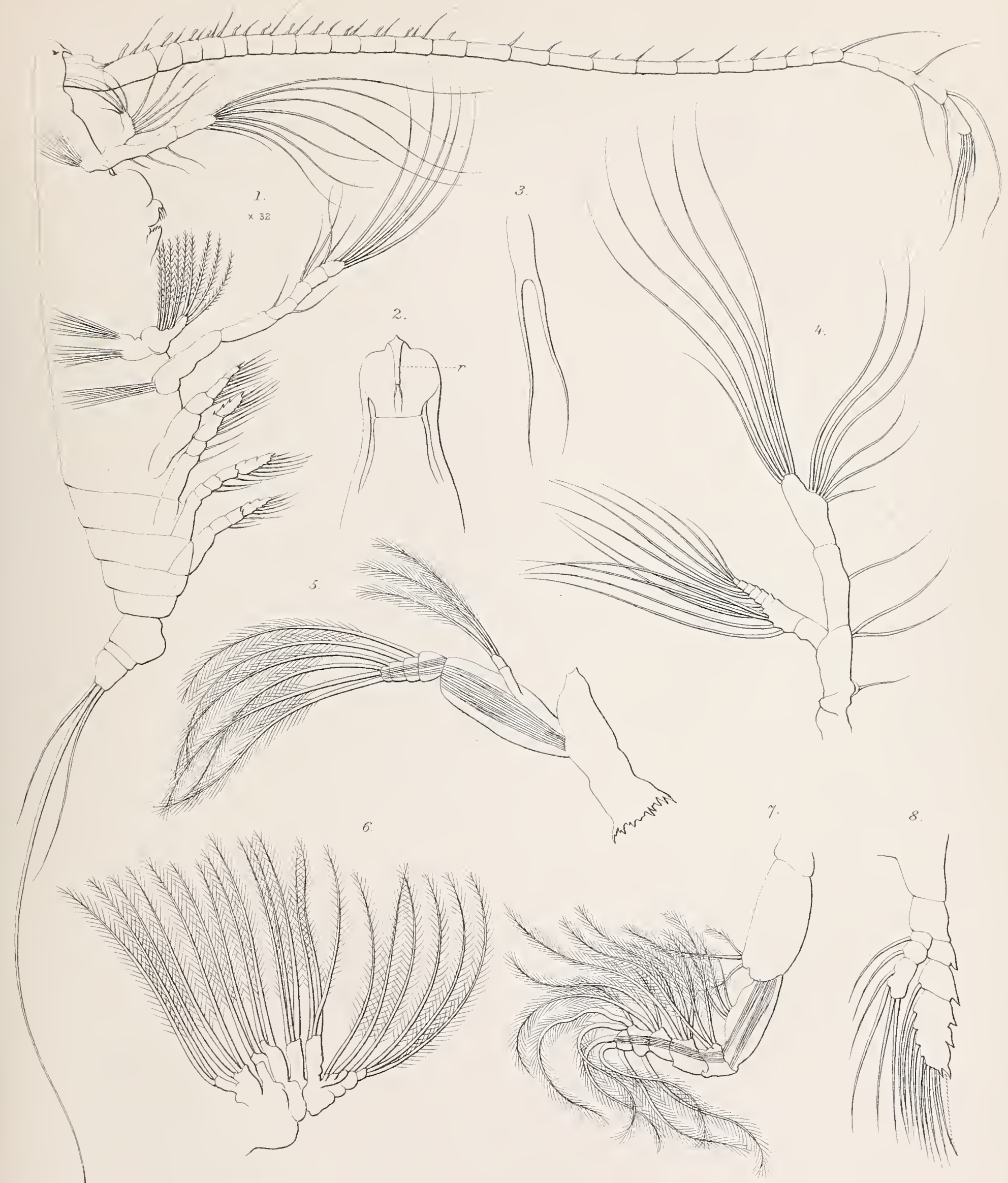



\section{PLATE VIL.}

(zoOL. CHALL. EXP. - PaRT XXIII. -1883.) - Z. 


\section{PLATE VII.}

\section{Rhincalames cormutus, Dana.}

Fig. 1. Female, seen from above, magnified 32 diameters.

Fig. 2. Another specimen, seen from right side, magnified 40 diameters.

Fig. 3. Posterior antenna.

Fig. 4. Mandible and palp.

Fig. 5. Maxilla.

Fig. 6. Anterior foot-jaw.

Fig. 7. Posterior foot-jaw.

Fig. 8. Foot of first pair.

Fig. 9. One of the swimming feet, second, third, or fourth pair.

Fig. 10. Fifth pair of feet. 


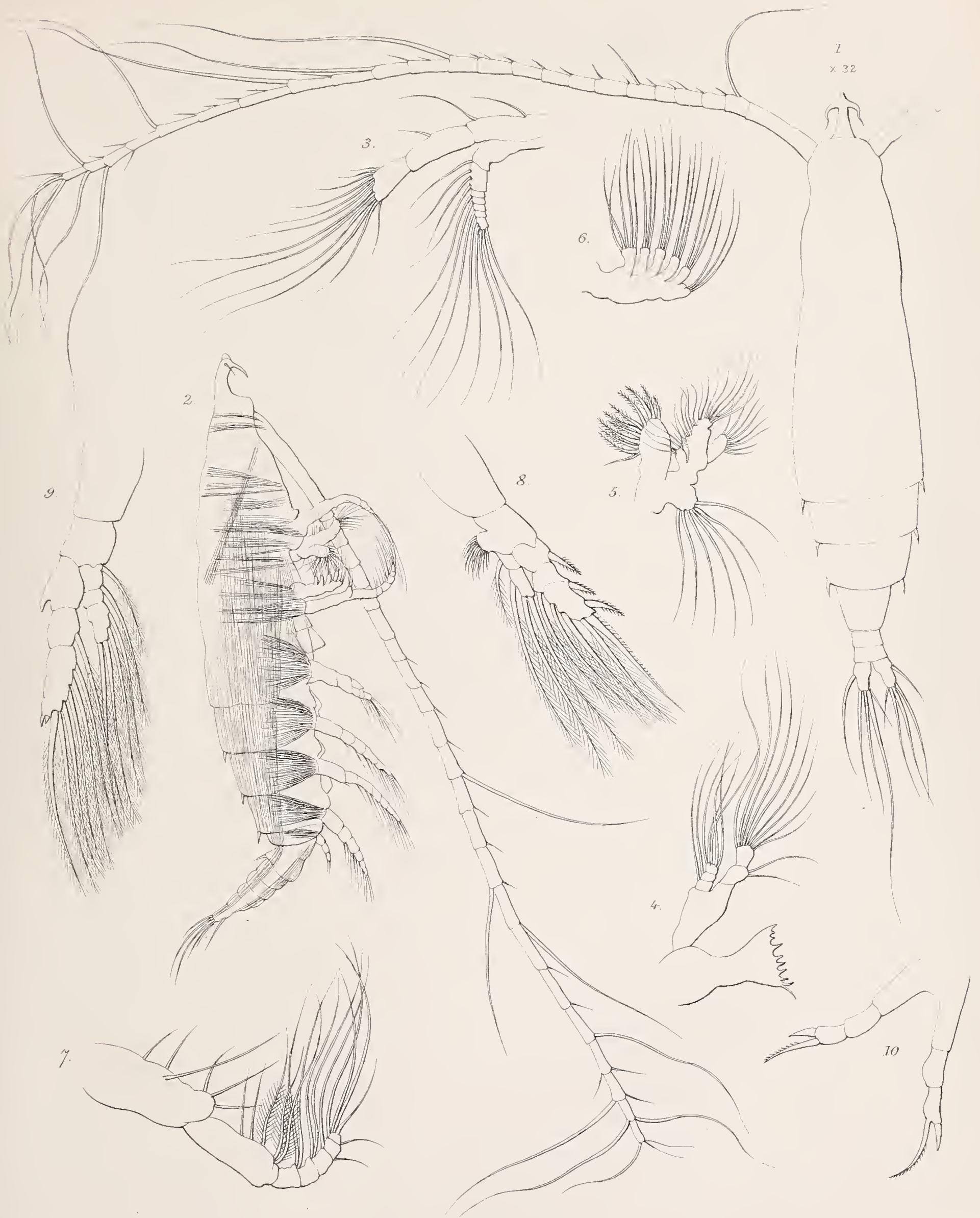



PLA'TE VIII. 


\section{PLATE VIII.}

\section{Rhincalanus gigas, n. sp.}

Fig. 1. Female, seen from right side, magnified 16 diameters.

Fig. 1 $a$. Last thoracic segment, seen from below.

Fig. 2. Posterior antenna.

Fig. 3. Mandible and palp.

Fig. 4. Maxilla and palp.

Fig. 5. Anterior foot-jaw.

Fig. 6. Posterior foot-jaw.

Fig. 7. Foot of first pair.

Fig. 8. Foot of fourth pair.

Fig. 9. Fifth pair of feet.

Fig. 10. The same from another specimen.

Fig. 11. Abdomen and tail. 


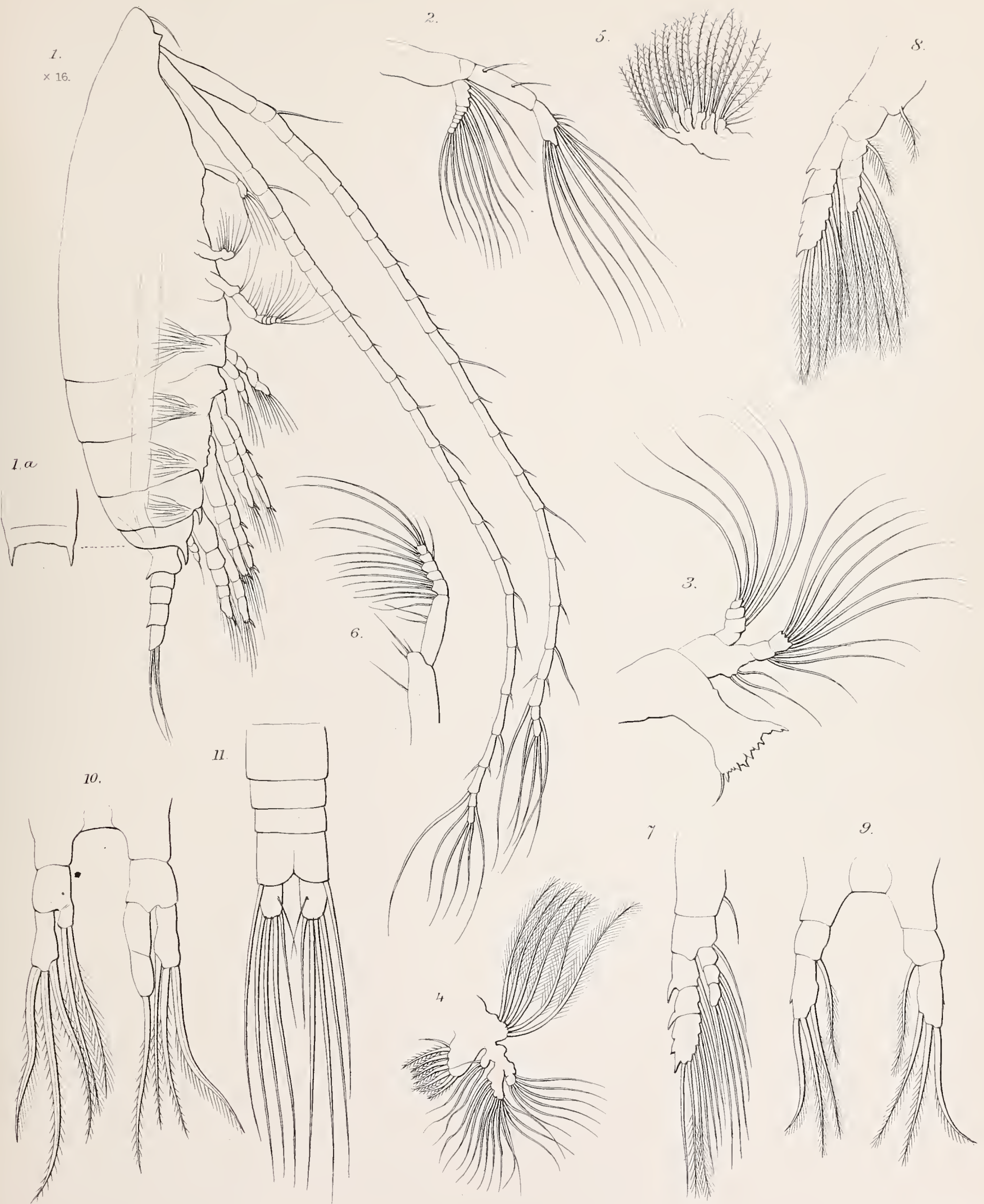





\section{PLATE IX.}

(ZOOL. CHALL. EXP.—PART XXII.-1883.)-Z. 


\section{PLATE IX.}

Figs. 1-7. Hemicalanus longicomis, Claus.

Fig. 1. Male (?), seen from above, magnified 40 diameters.

Fig, 2. Posterior antenna.

Fig. 3. Mandible and palp.

Fig. 4. Maxilla.

Fig. 5. Anterior foot-jaw.

Fig. 6. Posterior foot-jaw.

Fig. 7. Foot of fifth pair (female).

Figs. 8-9. Hemicalanus orientalis, n. sp.

Fig. 8. Foot of fourth pair.

Fig. 9. Foot of fifth pair. 


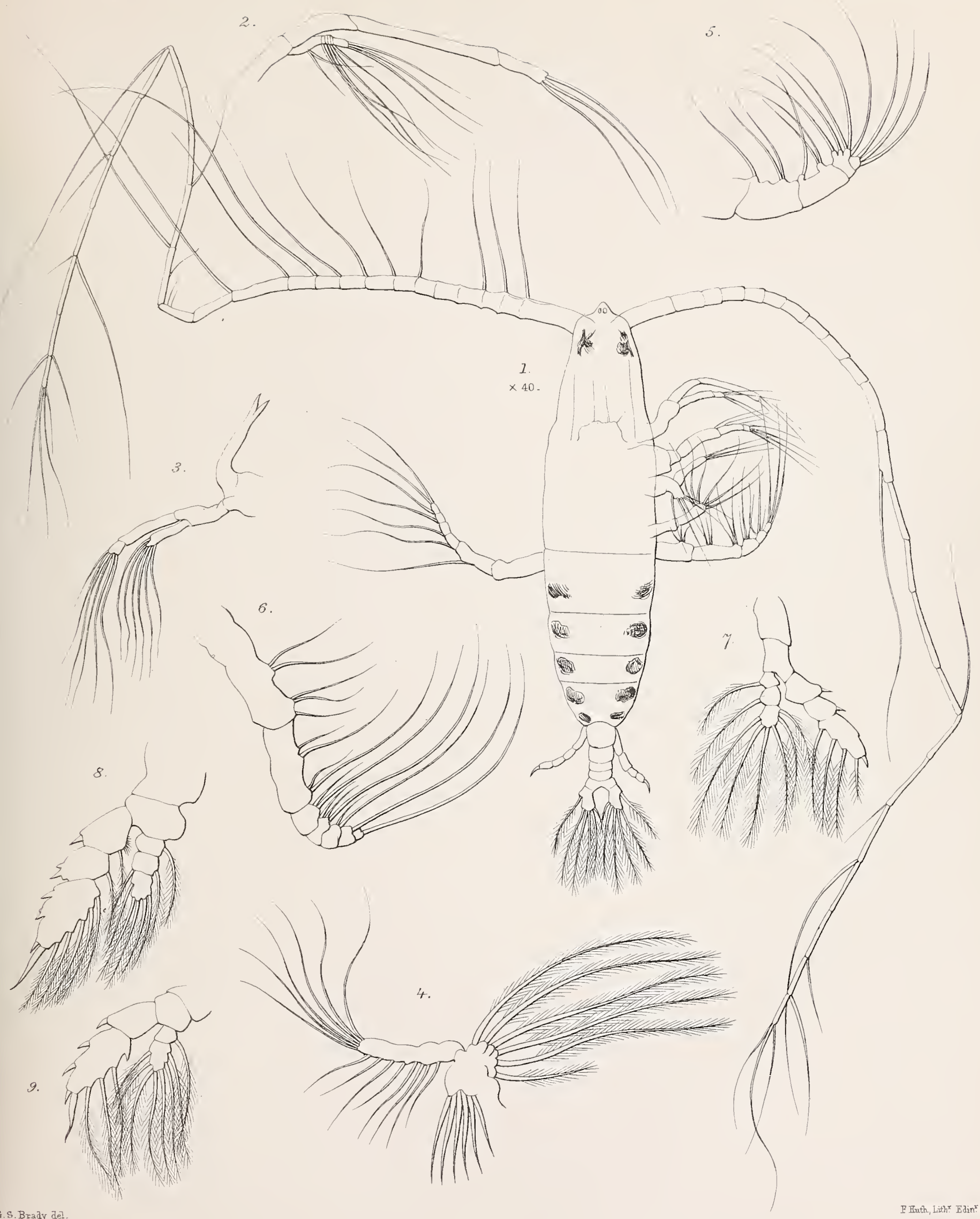

G.S. Brady del. 

PLATE X. 


\section{PLATE X.}

Figs. 1-4. Hemicalanus orientalis, n. sp.

Fig. 1. Anterior antenna, magnified 50 diameter's.

Fig. 2. Anterior foot-jaw.

Fig. 3. Posterior foot-jaw.

Fig. 4. Abdomen and tail (imperfect).

Figs. 5-16. Atidius armatus, n. gen. and sp.

Fig. 5. Female, seen from right side magnified 50 diameters.

Fig. 6. Anterior antenna.

Fig. 7. Posterior antenna.

Fig. 8. Mandible.

Fig. 9. Anterior foot-jaw.

Fig. 10. Posterior foot-jaw.

Fig. 11. Foot of first pair.

Fig. 12. Foot of second pair.

Fig. 13. Inner branch and base of third foot.

Fig. 14. Inner branch of fourth foot.

Fig. 15. Fifth pair of feet of male.

Fig. 16. Abdomen and posterior thoracic spines of female. 


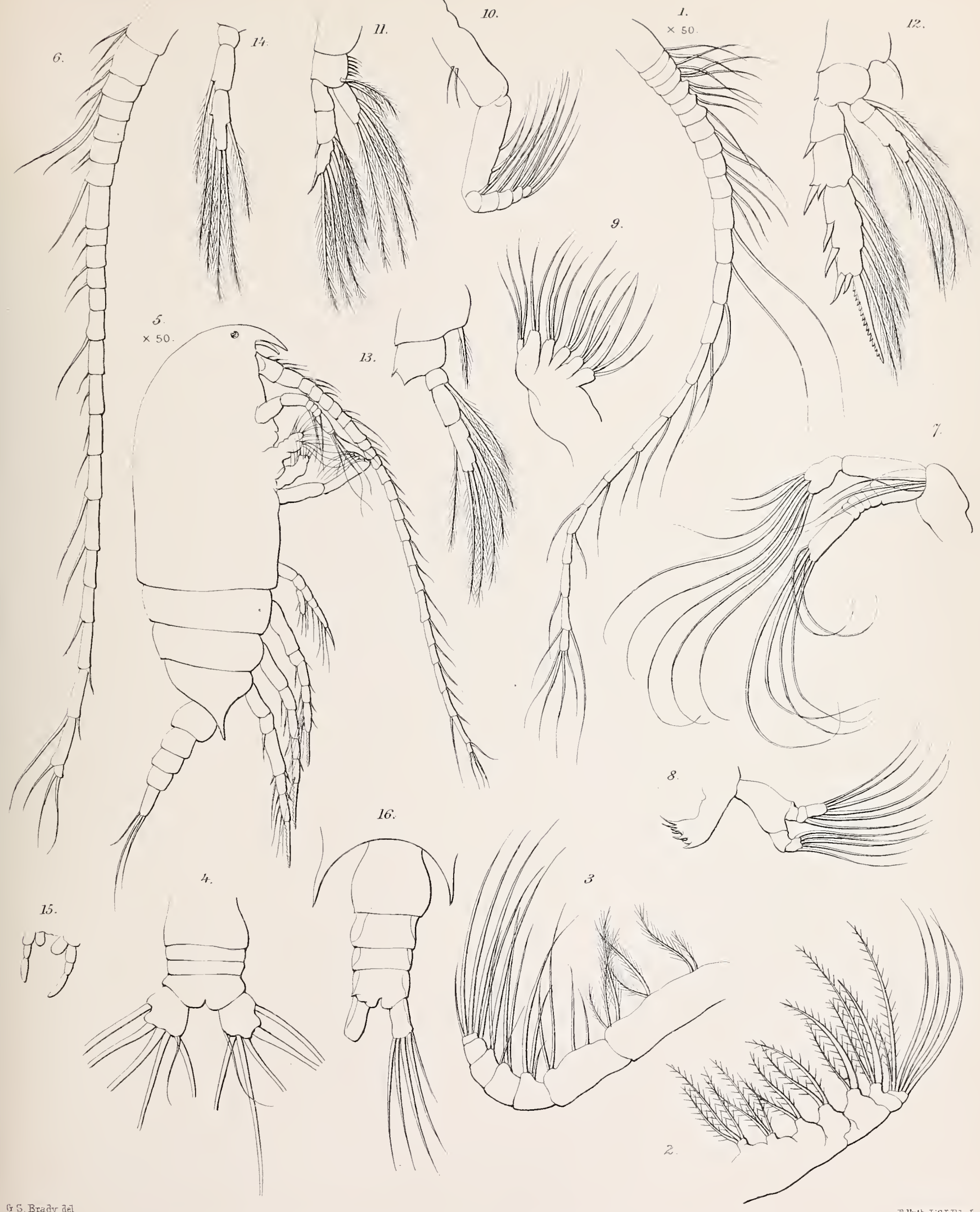

F Hoth, Jith? Edzur 

PLATE XI.

(ZOOL. CHALL. EXP. -PART XXIII.-1883.)-Z 


\section{PLA'TE XI.}

Pleuromma abdominale (Lubbock).

Fig. 1. Adult female, seen from above, magnified 40 diameters.

Fig. 2. Antennal hooks of the same.

Fig. 3. Left anterior antenna of male.

Fig. 4. Right anterior antenna of male.

Fig. 5. Denticulated plate of the same more highly magnified.

Fig. 6. Second foot of left side, male.

Fig. 7. Foot of third pair, male.

Fig. 8. Fifth pair of feet of adult male.

Fig. 9. Fifth pair of feet of immature male.

Fig. 10. Fifth pair of feet of adult female.

Fig. 11. Fifth pair of feet of immature female.

Fig 12. Abdomen of adult male.

Fig. 13. Abdomen of less fully developed (?) male. 


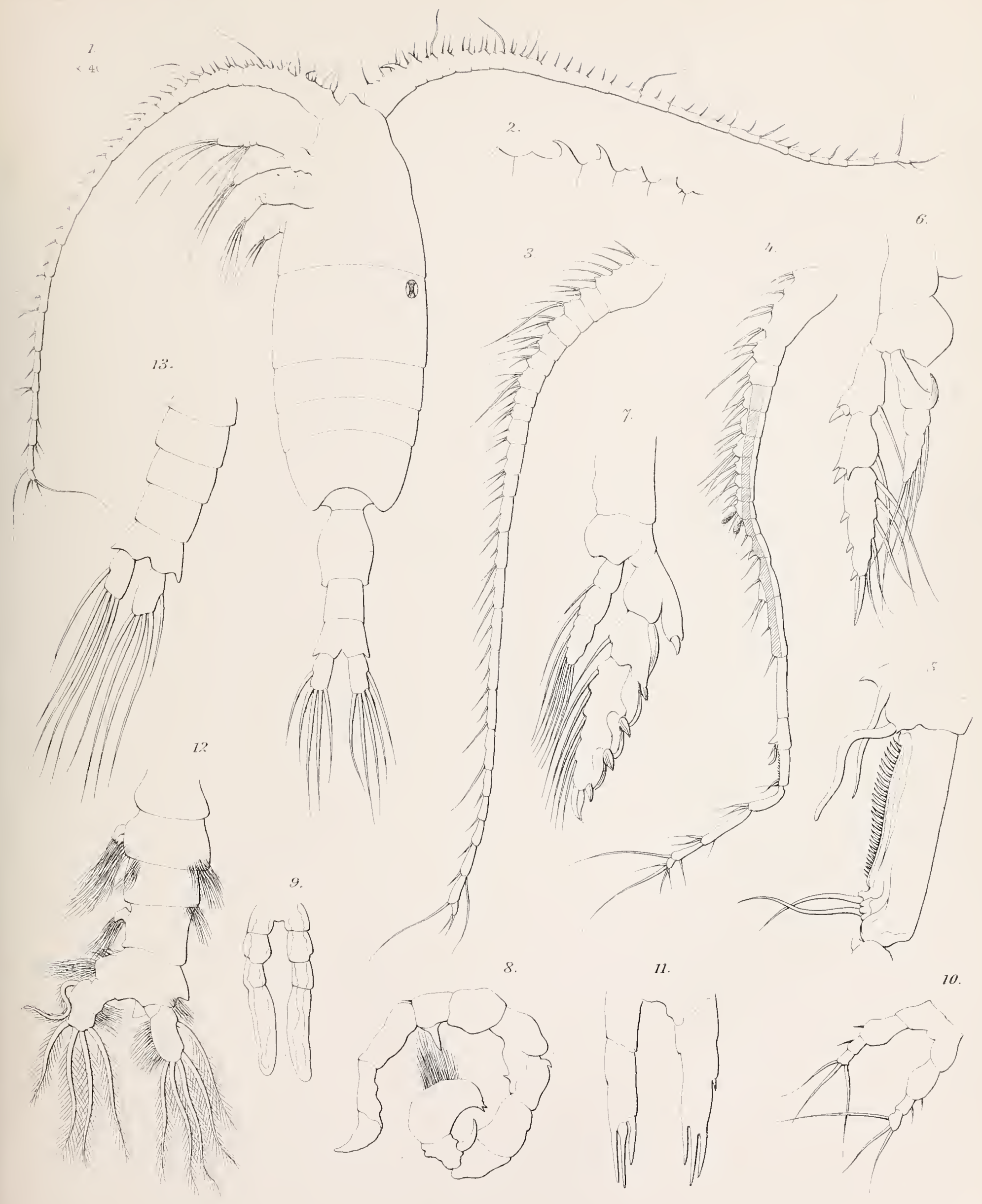



PLATE XII. 


\section{PLATE XII.}

\section{Pleuromma abdominale (Lubbock).}

Fig. 1. Anterior antenna of female.

Fig. 2. Left anterior antenna of male.

Fig. 3. Mandible.

Fig. 4. Maxilla.

Fig. 5. Anterior foot-jaw, with eye.

Fig. 6. Posterior foot-jaw.

Fig. 7. Foot of first pair.

Fig. 8. Foot of second pair, female.

Fig. 9. Foot of third or fourth pair.

Figs. 10, 11. Fifth pair of feet of male (two different specimens).

Figs. 12, 13. Fifth pair of feet of female (two distinct stages).

Fig. 14. Abdomen of male.

Fig. 15. Abdomen of female.

Fig. 16. Abdomen of female seen laterally, showing receptuculum seminis and fifth pair of feet.

(The figures in this Plate are for the most part drawn from what seems to be an immature form,-identical with Pleuromma gracile, Claus.) 


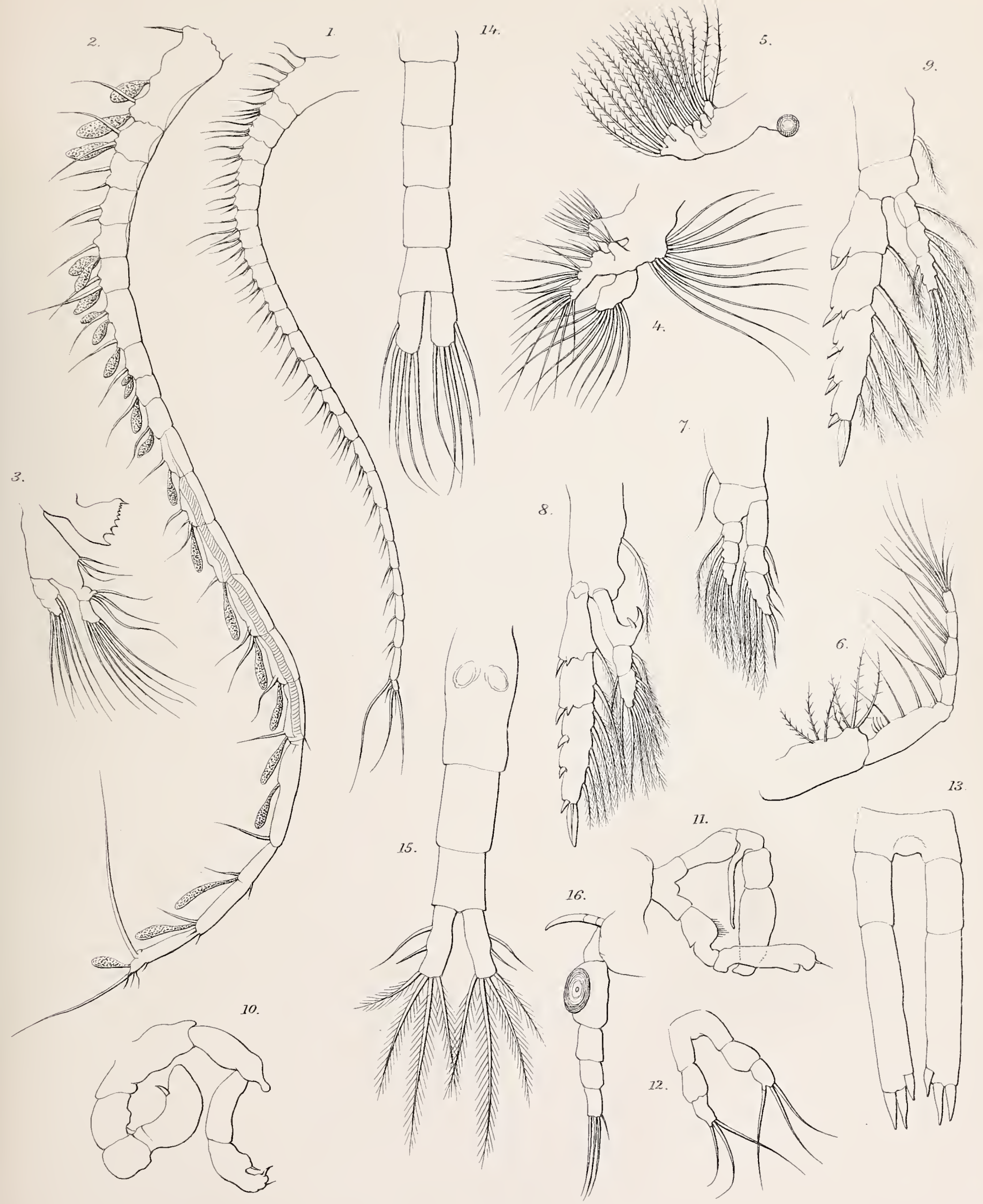


$$
\text { . }
$$ 


\section{PLA'TE XIII.}

(ZOOL. CHALL. EXP.-PART XXIII.-1883.)-Z 


\section{PLATE XIII.}

\section{Heterochata spinifions, Claus.}

Fig. 1. Female, seen from above, magnified 20 diameters.

Fig. 2. Anterior antemna of female.

Fig. 3. Left anterior antenna of male.

Fig. 4. Posterior antemna.

Fig. 5. Mandible and palp.

Fig. 6. Maxilla.

Fig. 7. Anterior foot-jaw.

Fig. 8. Posterior foot-jaw.

Fig. 9. Outer branch of third swimming foot.

Fig. 10. Fifth pair of feet of male.

Fig. 11. Fifth pair of feet of female.

Fig. 12. Abdomen of female, with spermatophore attached.

Fig. 13. Portion of sper matophore, with spermatozoids, more highly magnified. 


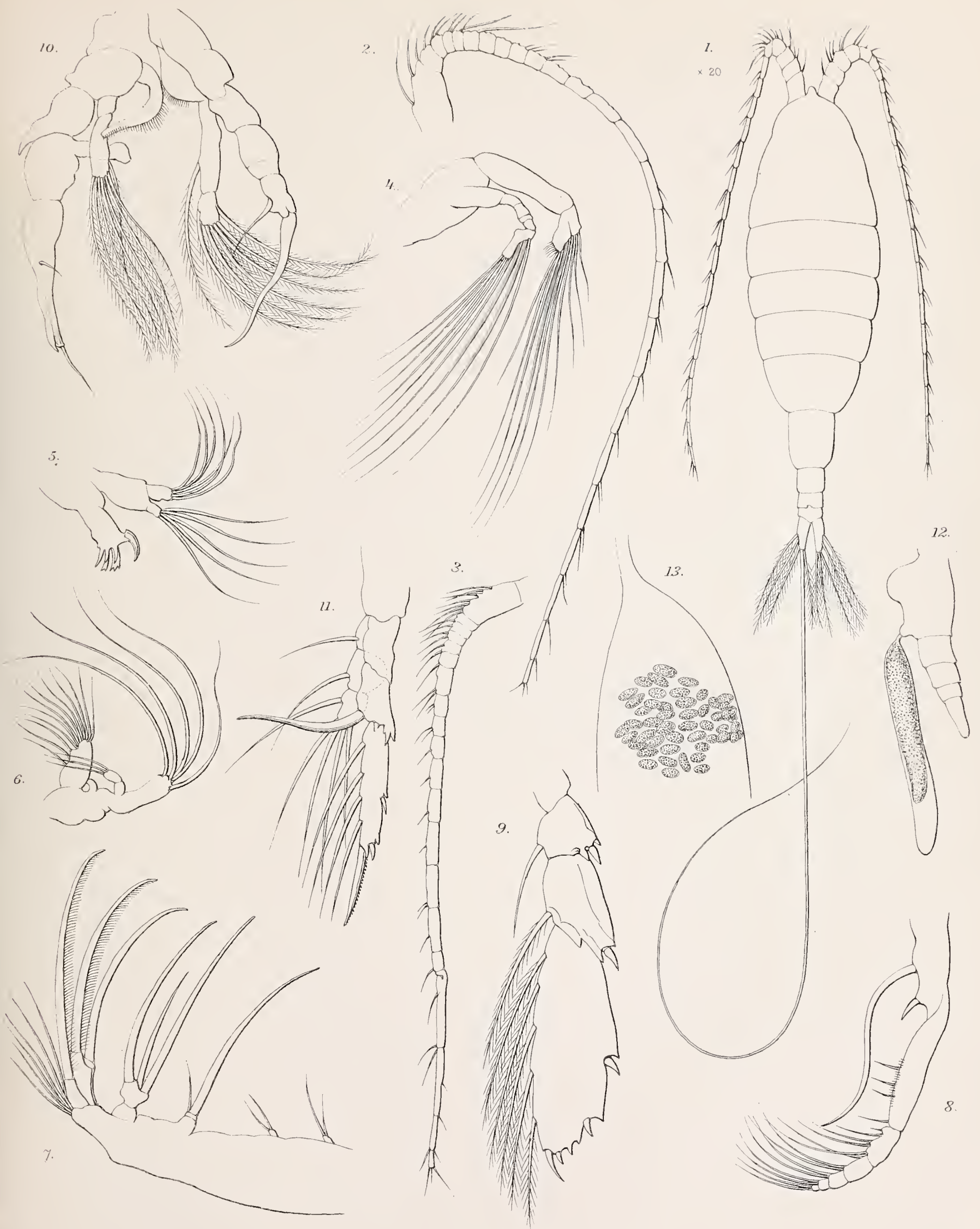



PLATE XIV. 


\section{PLATE XIV.}

Figs. 1-5. Leuckartia scopularis, n. sp.

Fig. 1. Right anterior antenna of male.

Fig. 2. Geniculating portion of left anterior antemna of male.

Fig. 3. Foot of the fifth pair, left side (imperfect), male.

Fig. 4. Foot of fifth pair, right side, male.

Fig. 5. Abdomen of male.

Figs. 6-9. Euchata pulchra (Lubbock.)

Fig. 6. Female, seen from left side, magnified 20 diameters.

Fig. 7. Anterior antenna of male.

Fig. 8. Anterior antenna of female.

Fig. 9. Anterior foot-jaw of female.

Figs. 10, 11. Calanus propinquus, n. sp.

Fig. 10. Fifth pair of feet of male.

Fig. 11. Terminal spines of one of the swimming feet. 
T1. Voyage of H M S' Challenger

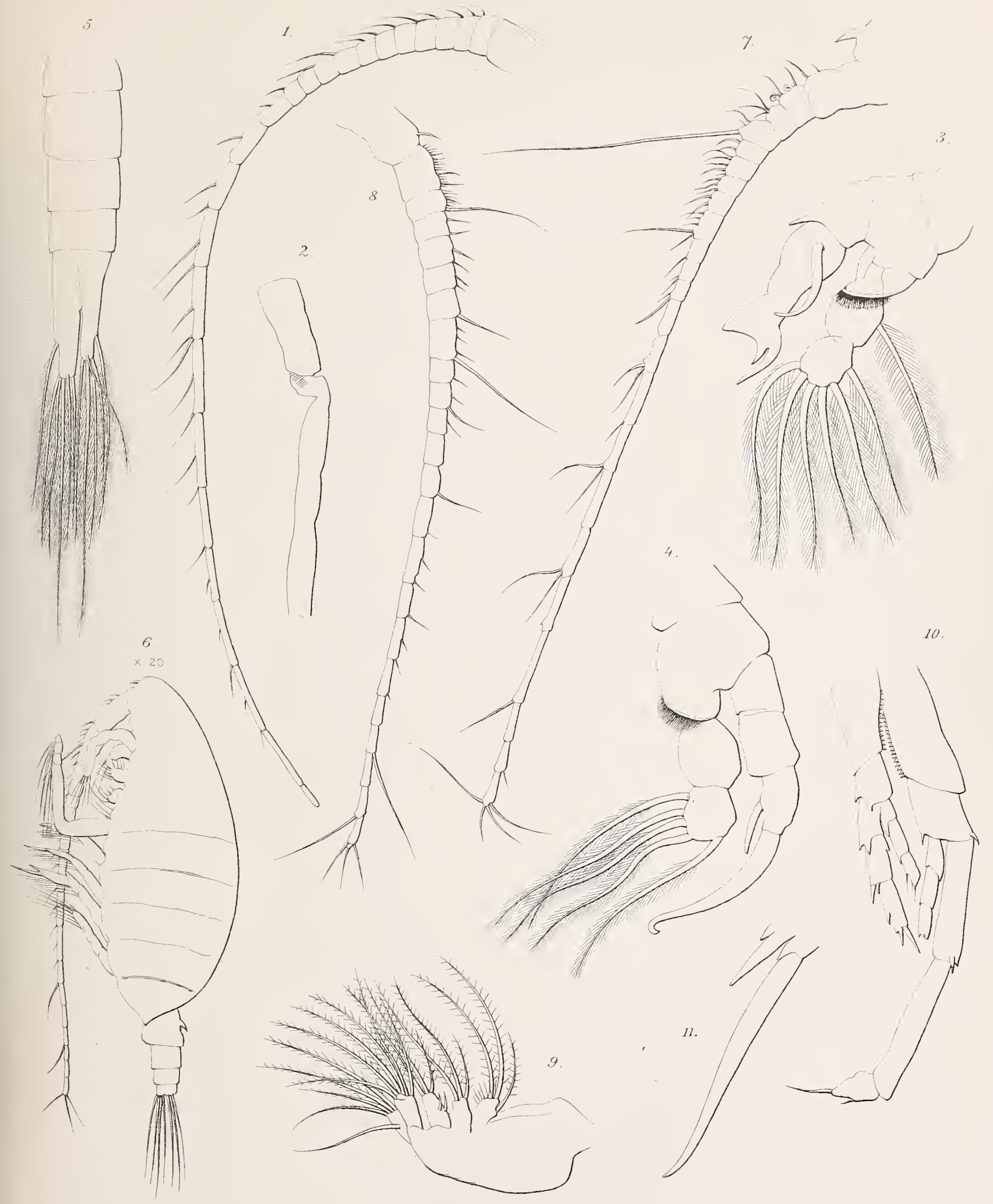

G.S.Brady del 

PLATE XV.

ZOOL. CBALL. EXP. - PART XXIII. - 1883.) -Z. 


\section{PLATE XV.}

Figs. 1-10, 16. Leuckartia flavicornis, Claus.

Fig. 1. Female, seen from left side, magnified 16 diameters.

Fig. 2. Left anterior antenna of male.

Fig. 3. Terminal joints of the same, more highly magnified.

Fig. 4. Posterior antenna.

Fig. 5. Mandible and palp.

Fig. 6. One of the swimming feet.

Fig. 7. Terminal spines of the same, more highly magnified.

Fig. 8. Right fifth foot of male.

Fig. 9. Left fifth foot of male.

Fig. 10. Abdomen of male.

Fig. 16. Maxilla.

Figs. 11-15. Undina vulgaris, Dana.

Fig. 11. Anterior antenna of male.

Fig. 12. Anterior antenna of female.

Fig. 13. Foot of second pair.

Fig. 14. Fifth pair of feet of male

Fig. 15. Abdomen of male. 


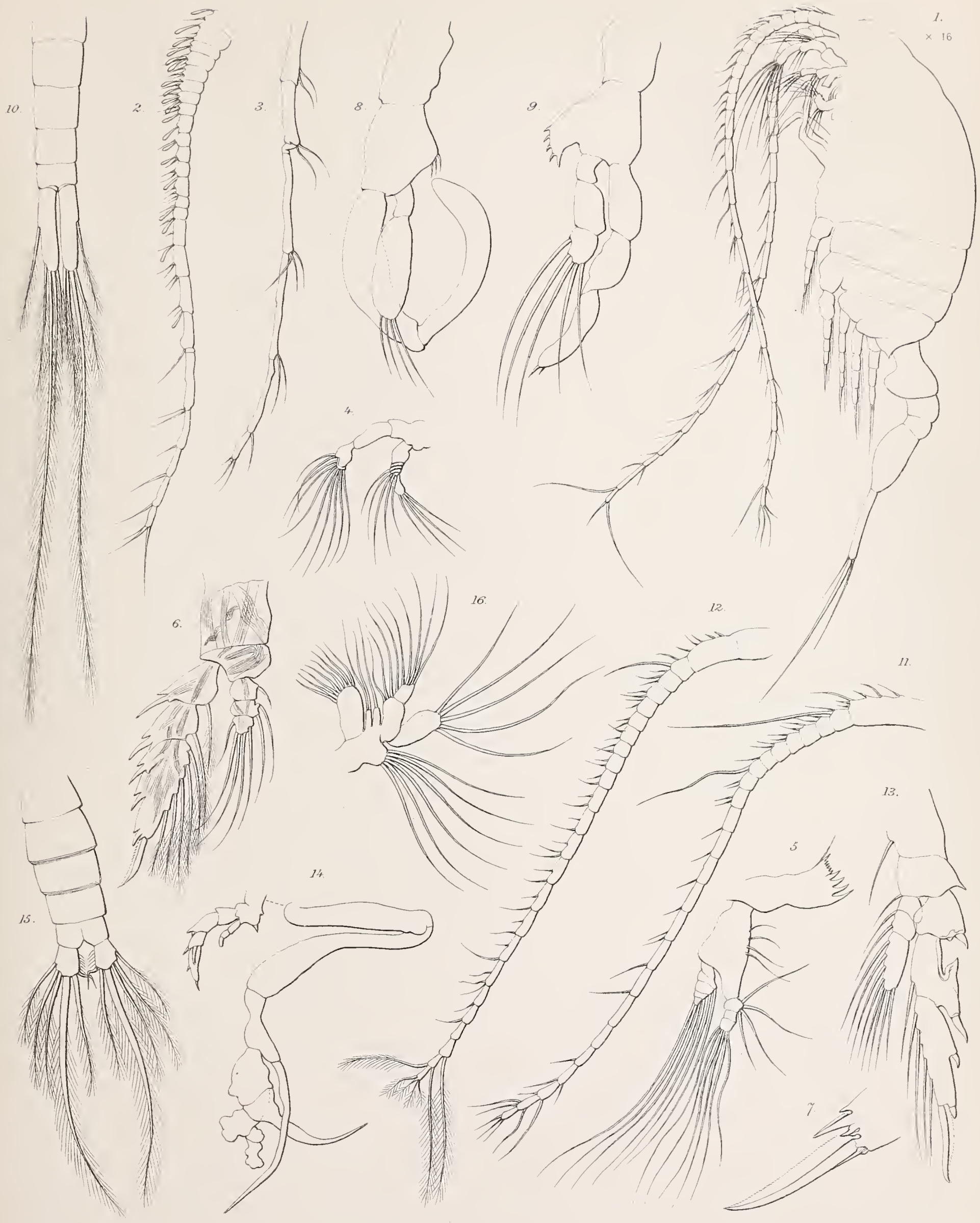



PLA'IE XVI. 


\section{PLATE XVI.}

Figs. 1-4, 6-14. Undina darwinii, Lubbock.

Fig. 1. Male, seen from left side, magnified 40 diameters.

Fig. 2. Anterior antenna of male.

Fig. 3. Anterior antenna of female.

Fig. 4. Apical joints of the same, more highly magnified.

Fig. 6. Mandible and palp.

Fig. 7. Maxilla.

Fig. 8. Anterior foot-jaw.

Fig. 9. Posterior foot-jaw.

Fig. 10. Outer braneh and base of third swimming foot.

Fig. 11. Right fifth foot of male.

Fig. 12. Left fifth foot of male.

Fig. 13. Abdomen of male.

Fig. 14. Abdomen of female.

Figs. 15, 16. Scolecithrix minor, 11. sp.

Fig. 15. Fifth pair of feet of male.

Fig. 16. Fifth pair of feet of female.

('The antemna represented in fig. 5 is that of a species of Calanus (?finmarchicus), and does not properly belong to this plate.) 

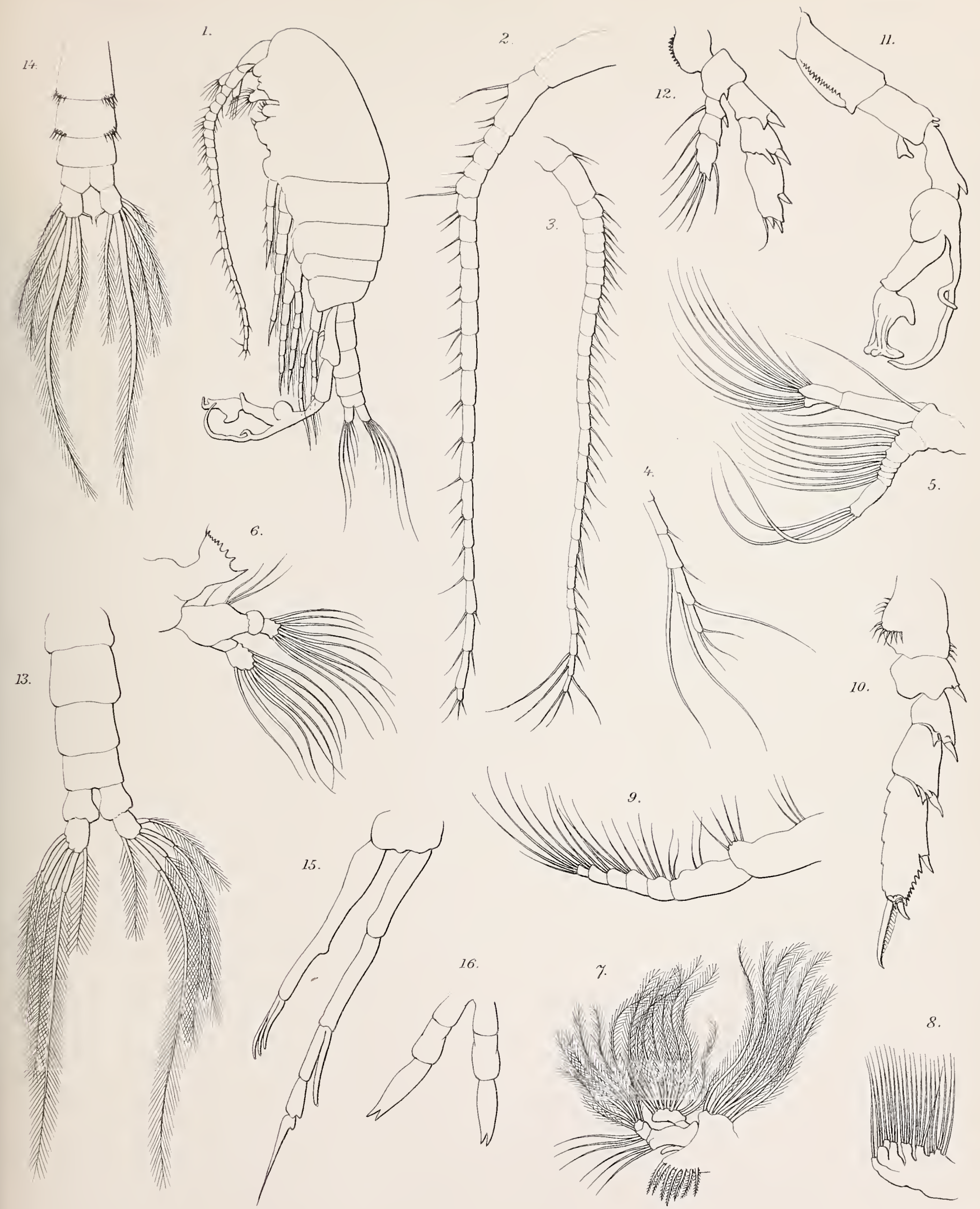

G S. Bràdy del 

PLATE XVII.

(ZOOL. CHALL EXP.-PART XXIII.-1883.)-Z Z 


\section{PLATE XVII.}

\section{Scolecithrix dance (Lubbock).}

Fig. 1. Male, seen from left side, magnified 40 diameters.

Fig. 2. Anterior antenna of male.

Fig. 3. Anterior antenna of female.

Fig. 4. Posterior antenna.

Fig. 5. Mandible and palp.

Fig. 6. Maxilla.

Fig. 7. Anterior foot-jaw.

Fig. 8. Terminal spines of one of the swimming feet.

Fig. 9. Fifth pair of feet of male.

Fig. 10. The same, immature.

Fig. 11. Abdomen of female, seen from front.

Fig. 12. The same seen from left side. 


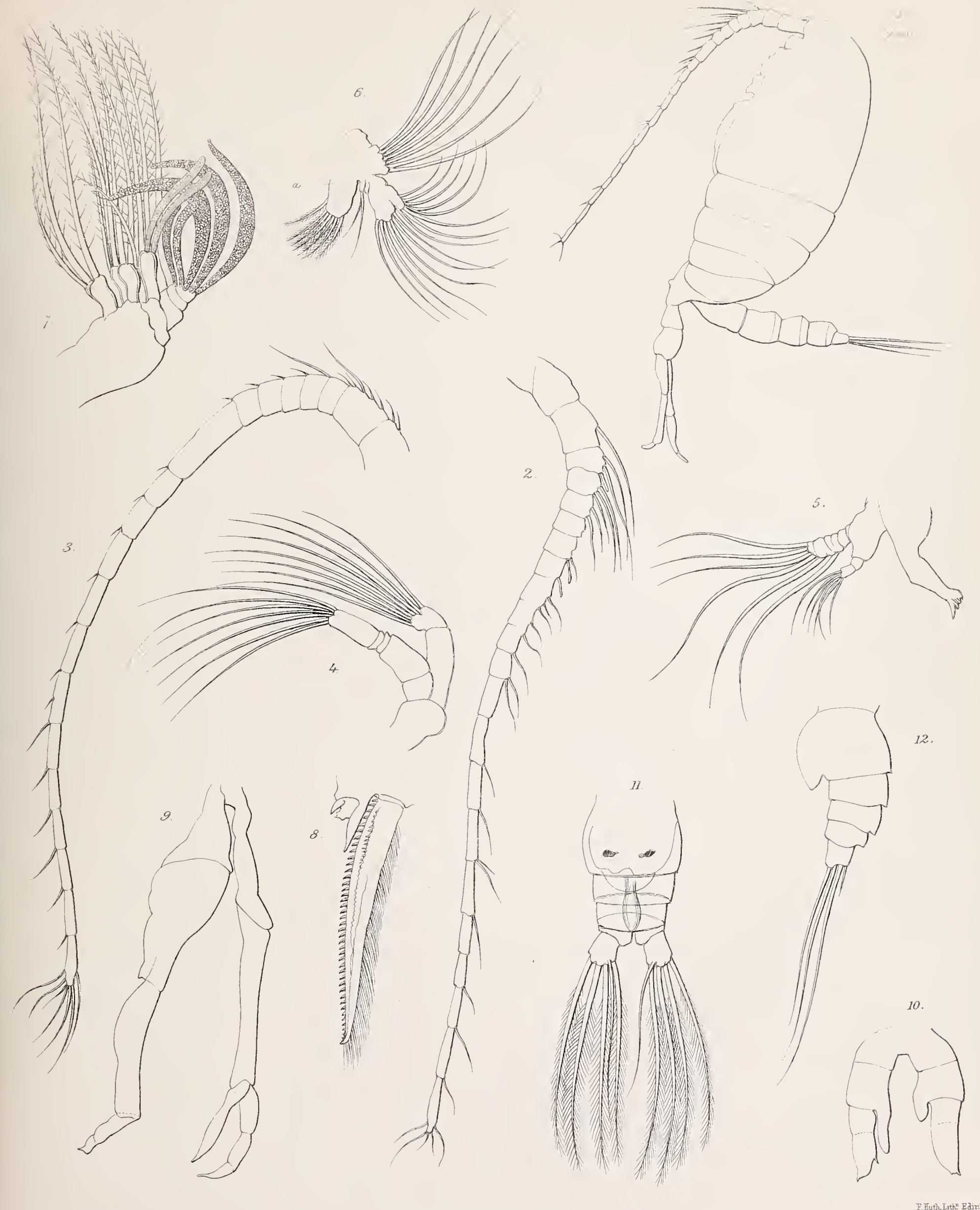

GS.Brady del. 

PLATE XVIII. 


\section{PLATE XVIII.}

Figs. 1-5. Scolecithrix minor, n. gen. and sp.

Fig. 1. Female, seen from right side, magnified 55 diameters ; $a$, fifth foot.

Fig. 2. Anterior antenna of female.

Fig. 3. Maxilla.

Fig. 4. Anterior foot-jaw of male.

Fig. 5. Anterior foot-jaw of female.

Fig. 6. Undina vulgaris, Dana.

Fig. 6. Female, seen from left side, magnified 40 diameters.

Figs. 7-15. Euchceta prestandrea, Philippi.

Male.

Fig. 7. Male, seen from right side, magnified 16 diameters.

Fig. 8. Anterior antenna.

Fig. 9. Mandible.

Fig. 10. Maxilla.

Fig. 11. Anterior foot-jaw.

Fig. 12. Posterior foot-jaw.

Fig. 13. Fifth pair of feet (adult); $a$, attached spermatophore.

Fig. 14. The same immature (sutherlandii, Lubbock).

Fig. 15. Abdomen. 


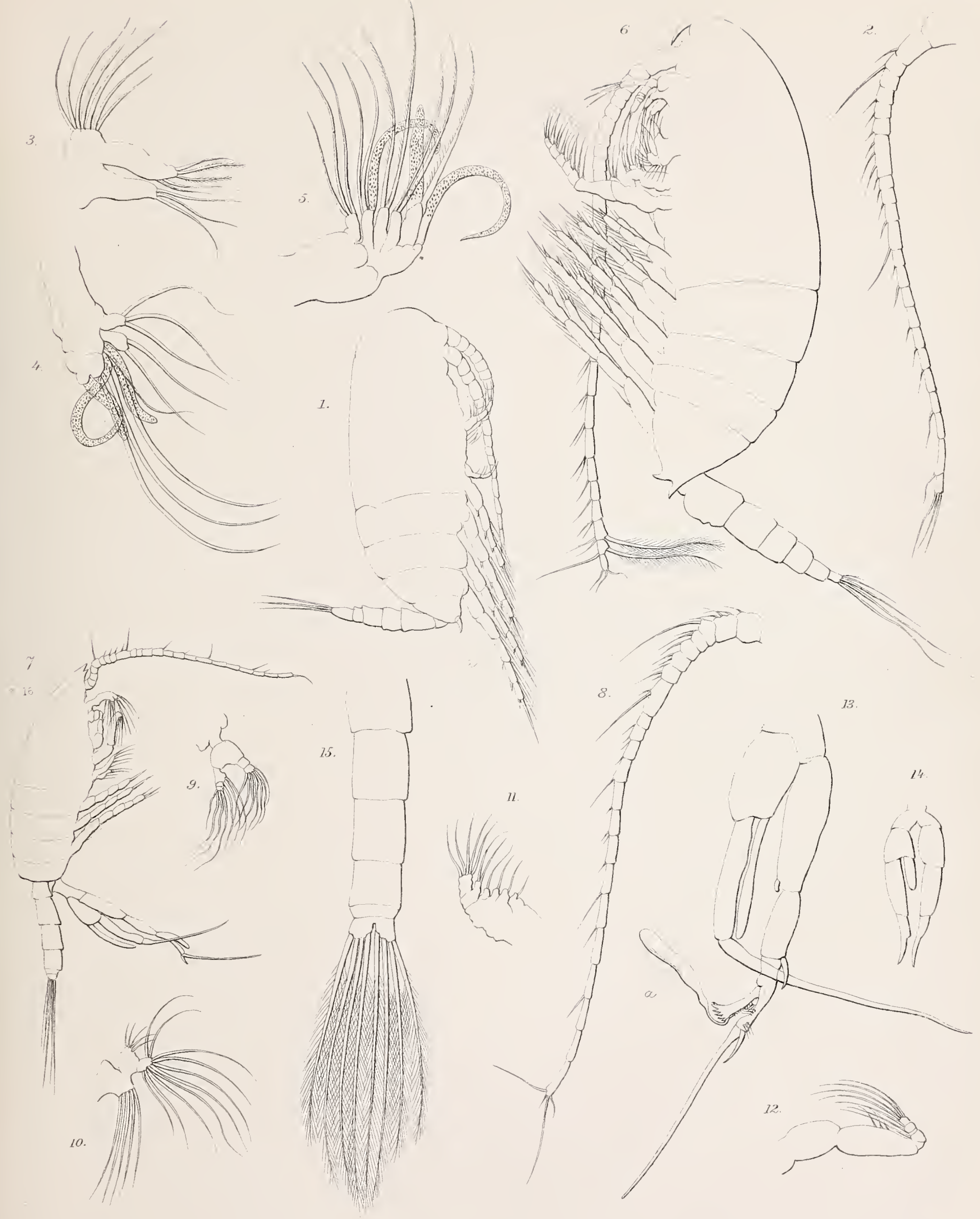




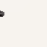




\section{PLATE XIX.}

(ZOOL. CHALL. EXP.-PART XXIII,-1883.)-Z, 


\section{PLATE XIX.}

\section{Euchata prestandrea, Philippi.}

\section{Female.}

Fig. 1. Female, seen from above, magnified 20 diameters.

Fig. 2. Female, seen from left side, magnified 40 diameters.

Fig. 3. Posterior antenna.

Fig. 4. Mandible and palp.

Fig. 5. Maxilla.

Fig. 6. Anterior foot-jaw.

Fig. 7. Posterior foot-jaw.

Fig. 8. Foot of first pair.

Fig. 9. Foot of second pair.

Fig. 10. Foot of third pair.

Fig. 11. Terminal spines of one of the swimming feet. 


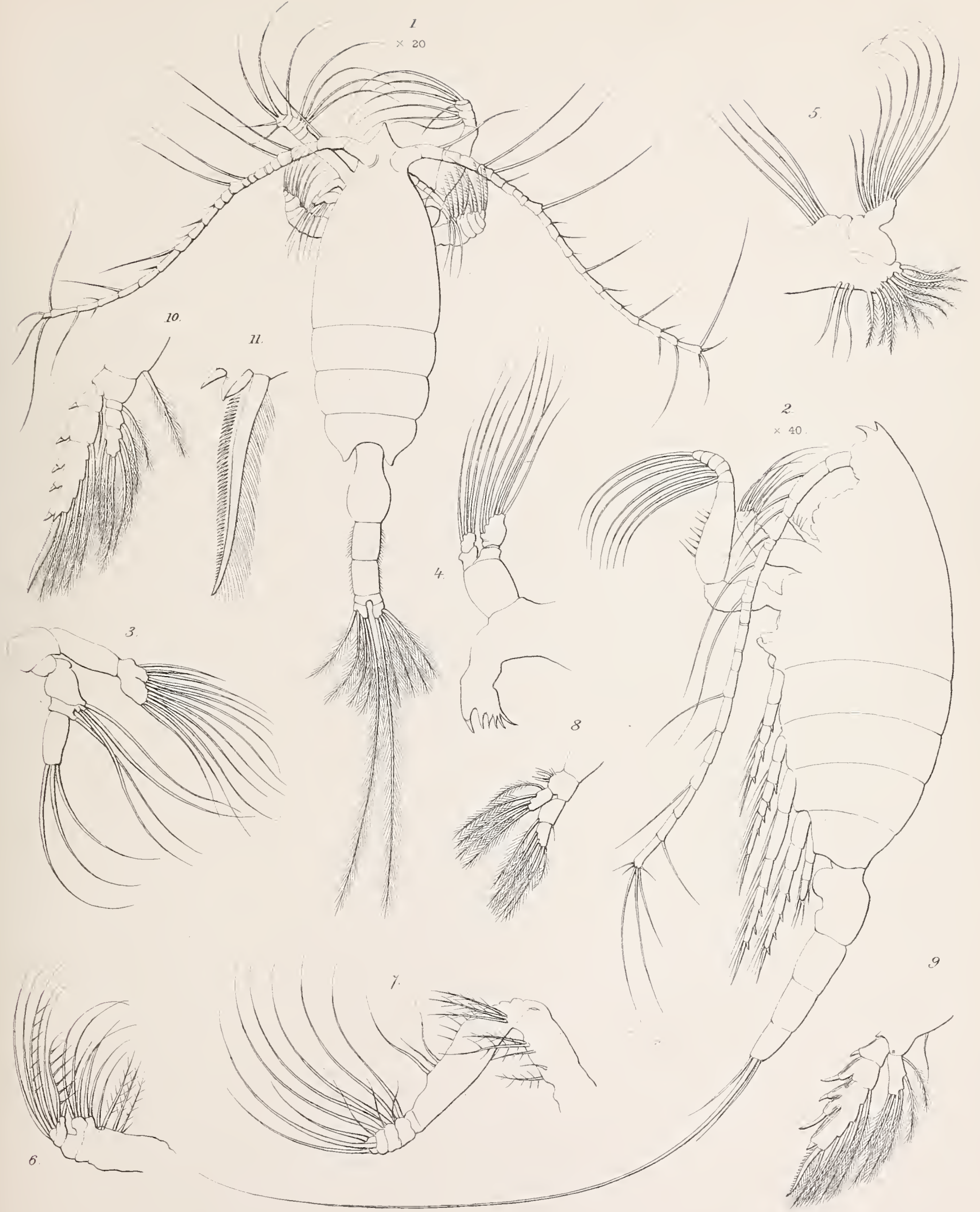



PLATE XX. 


\section{PLATE NX.}

Figs. 1-13. Euchata hessei, 11. sp.

Fig. 1. Male, seen from left side, magnified 40 diameters.

Fig. 2. Anterior antenna of female.

Fig. 3. Posterior antenna.

Fig. 4. Mandible.

Fig. 5. Maxilla of female.

Fig. 6. Maxilla of male.

Fig. 7. Anterior foot-jaw of female.

Fig. S. Posterior foot-jaw of female.

Fig. 9. Posterior foot-jaw of male.

Fig. 10. Terminal spines of one of the srimming feet.

Fig. 11. Fifth pair of feet of male.

Fig. 12. Abdomen of male.

Fig. 13. Abdomen of female.

Figs. 14-19. Euchata pulchra (Lubbock).

Fig. 14. Naxilla of female.

Fig. 15. Posterior foot-jaw of male.

Fig. 16. Posterior foot-jaw of female.

Fig. 17. Fifth pair of feet of male.

Fig. 18. Terminal spine of one of the swimming feet.

Fig. 19. Abdomen of male. 
The Voyage of H.M S "nallenger

Topep.id. PT XY

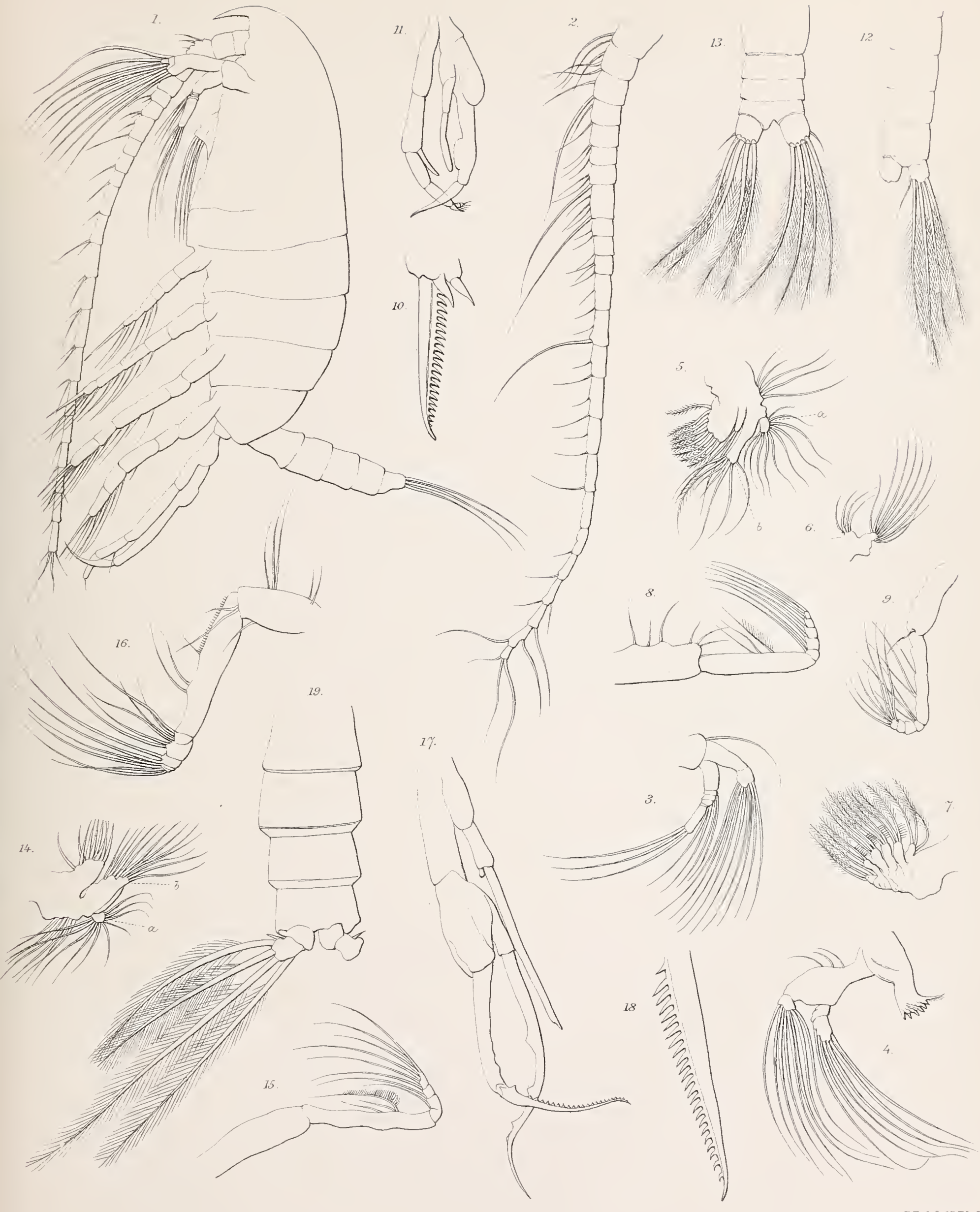

G... Brady de. 
PLAATE XXI.

(ZOOL. CHALL. FXP.-PART XXIII.-1883.)-Z. 


\section{PLATE XXI.}

Figs. 1 4. Euchceta philippii, n. sp.

Fig. 1. Female (?), seen from right side, magnified 16 diameters.

Fig. 2. Anterior antenna of the same.

Fig. 3. Terminal spines of one of the swimming feet.

Fig. 4. Fifth pair of feet.

Figs. 5-11. Euchoeta australis, n. sp.

Fig. 5. Female, seen from right side, magnified 32 diameters.

Fig. 6. Anterior antenna of male.

Fig. 7. Mandible and palp of female.

Fig. 8. Right foot of fifth pair of male.

Fig. 9. Left foot of the same.

Fig. 10. Abdomen of female.

Fig. 11. Terminal spines of one of the swimming feet. 


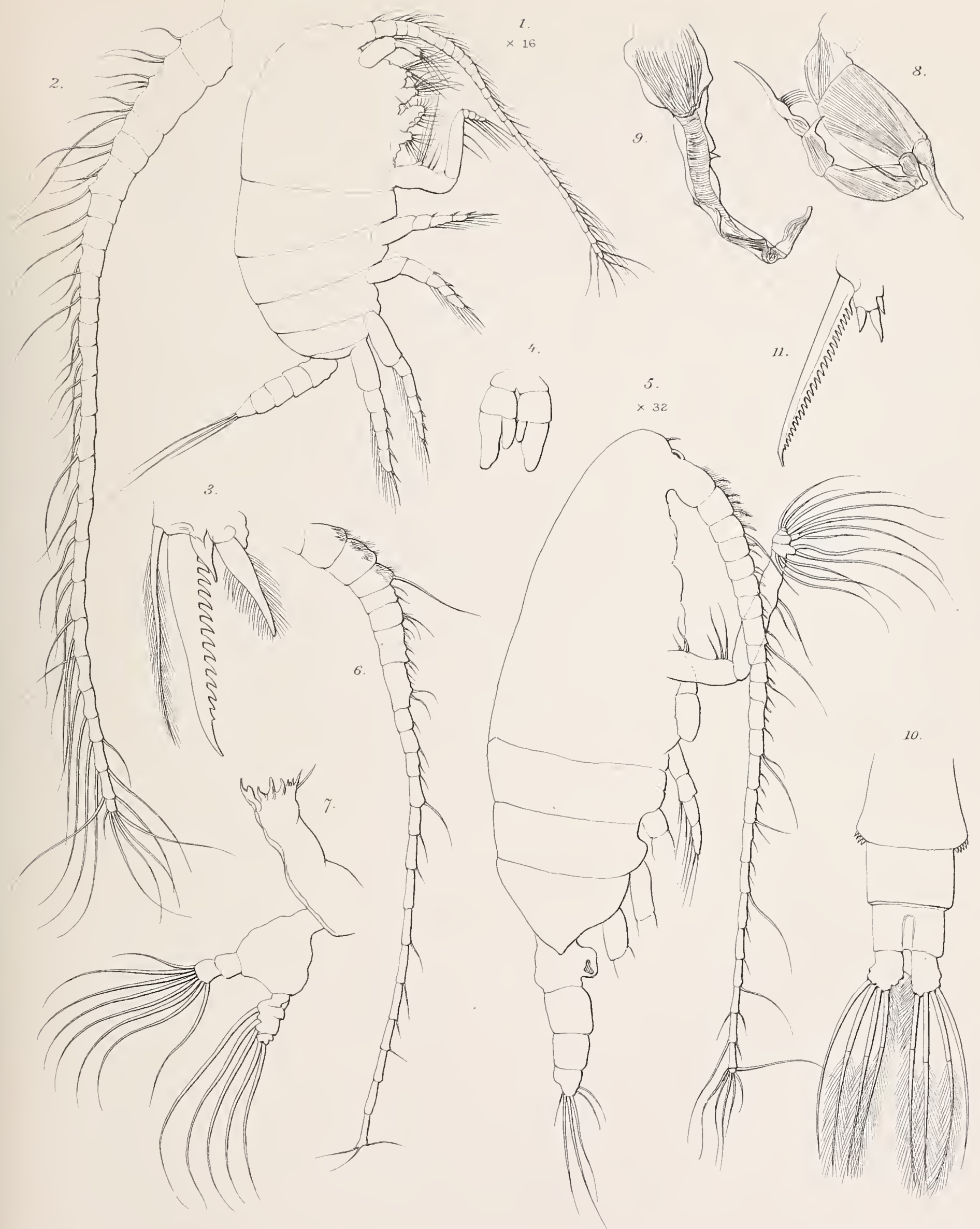



PLATE XXII 


\section{PLATE XXII}

Figs. 1-5. Euchota gigas, n. sp.

Fig. 1. Female seen from above, magnified 16 diameters.

Fig. 2. Anterior antenna.

Fig. 3. Extremity of mandible.

Fig. 4. Terminal spines of one of the swimming feet.

Fig. 5. Fifth pair of feet (? immature male).

Figs. 6-12. Euchota barbata, n. sp.

Fig. 6. Anterior antenna of female.

Fig. 7. Rostrum.

Fig. 8. Anterior foot-jaw.

Fig. 9. One of the proximal setre of the same, with base.

Fig. 10. Portion of one of the larger setæ of the same, more highly magnified.

Fig. 11. Foot of the second pair.

Fig. 12. Abdomen, with posterior angle of thorax. 


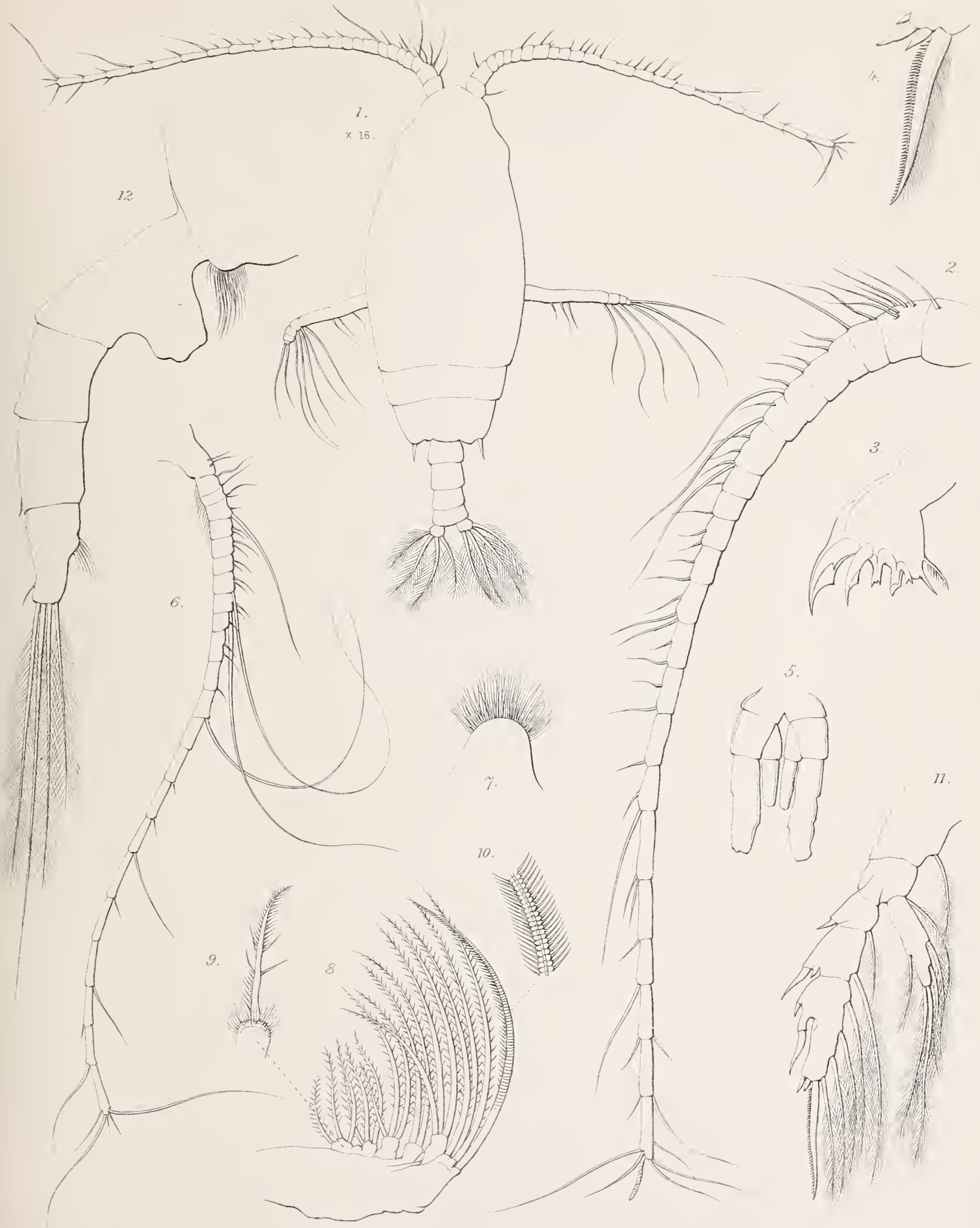





\section{PLATE XXIII.}

(ZOOL. CHALL. EXP.-PART XXIII.—1883.) - Z 


\section{PLATE XXIII.}

Figs. 1-10. Calanoides patagoniensis, n. gen. and sp.

Fig. 1. Male, seen from above, magnified 40 diameters.

Fig. 2. Posterior antenna.

Fig. 3. Mandible of male.

Fig. 4. Mandible of female.

Fig. 5. Maxilla of female.

Fig. 6. Anterior foot-jaw.

Fig. 7. Posterior foot-jaw of male.

Fig. 8. Foot of third pair.

Fig. 9. Fifth pair of feet of male.

Fig. 10. Abdomen of female.

Figs. 11-14. Euchceta hessei, n. sp

Fig. 11. Foot of first pair.

Fig. 12. Foot of second pair.

Fig. 13. Foot of fourth pair (female).

Fig. 14. Abdomen of female, with attached spermatophores. 

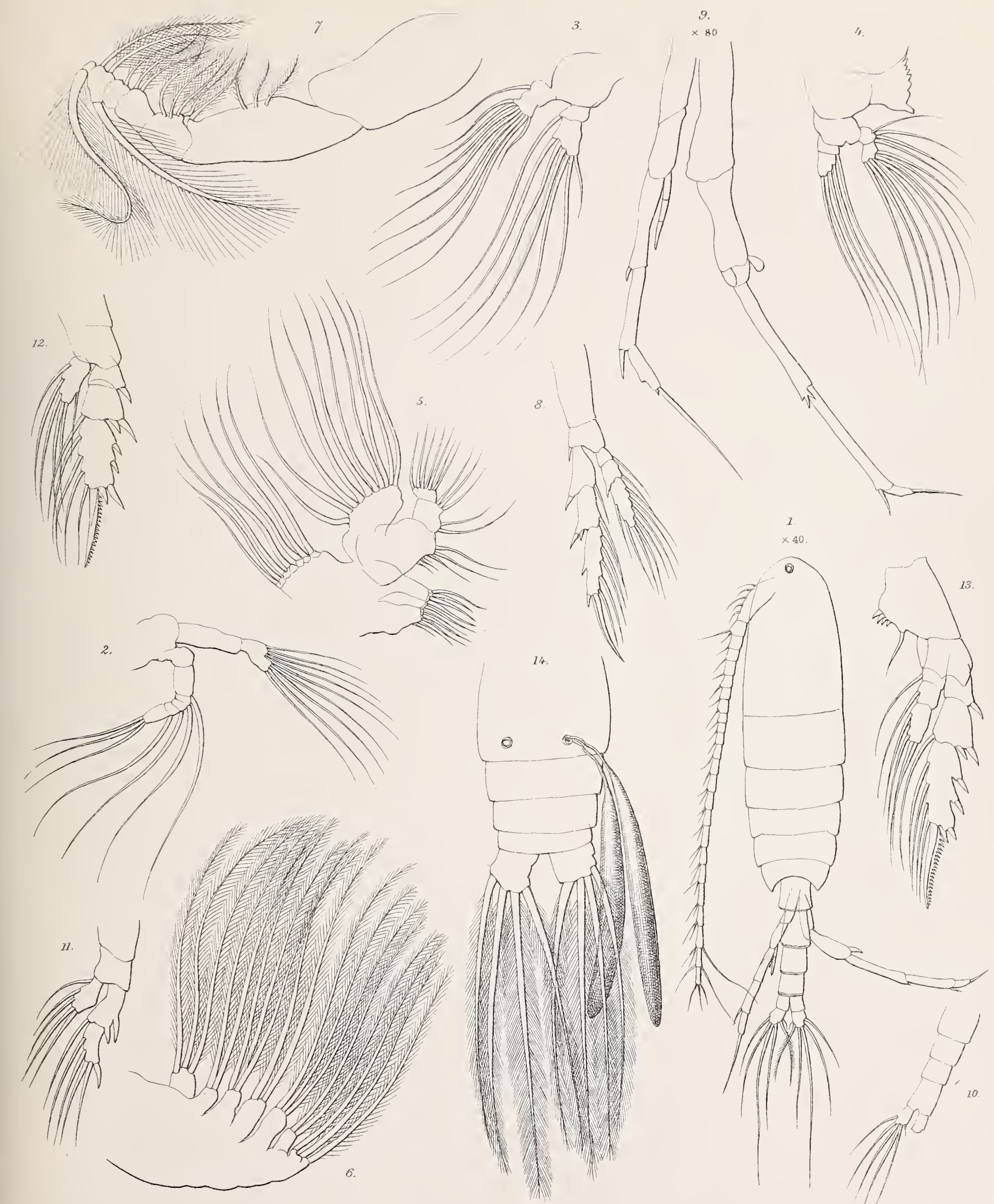

G.S Bra.aiy del. 



\section{PLATE XXIV.}




\section{PLATE XXIV.}

Figs. 1-11. Drepanopus pectinatus, n. gen. and sp.

Fig. 1. Female, seen from right side, magnified 40 diameters.

Fig. 2. Anterior antenna of female.

Fig. 3. Anterior antenna of male.

Fig. 4. Posterior antenna.

Fig. 5. Mandible and palp.

Fig. 6. Maxilla.

Fig. 7. Foot of first pair.

Fig. 8. Foot of second pair.

Fig. 9. Foot of fourth pair.

Fig. 10. Fifth pair of feet (female).

Fig. 11. Fifth pair of feet (male).

Figs. 12-15. Drepanopus furcatus, n. gen. and sp.

Fig. 12. Foot of second pair.

Fig. 13. Foot of fourth pair.

Fig. 14. Terminal spines of swimming foot.

Fig. 15. Fifth pair of feet (female). 


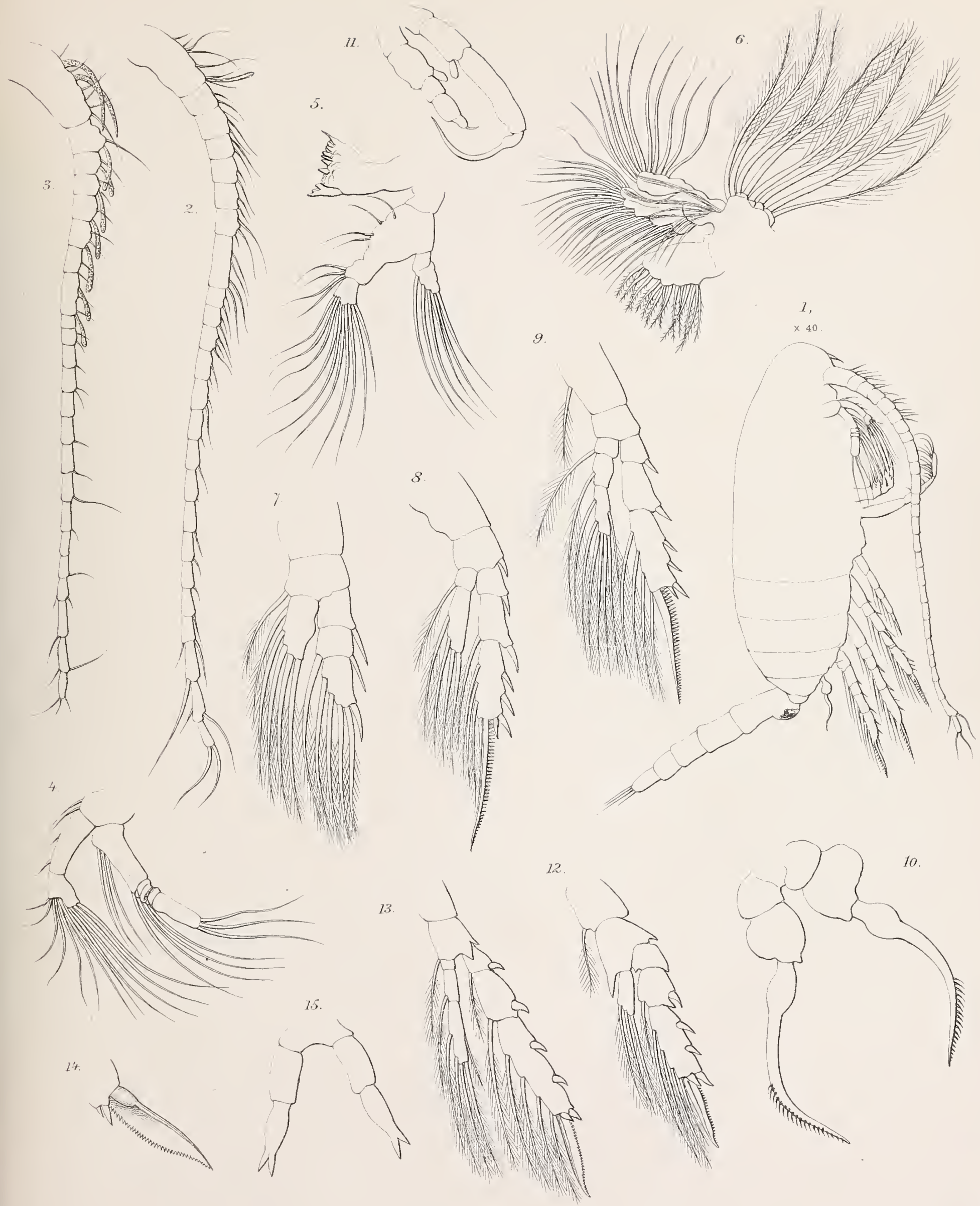

G.S. Erady dè 



\section{PLATE XXV.}

(ZOOL, CHALL. EXP.-PART XXIII.-1883.) -Z. 


\section{PLATE XXV.}

Temora dubia (Lubbock).

Fig. 1. Male, seen from right side, magnified 50 diameters.

Fig. 2. Right anterior antenna of male.

Fig. 3. Anterior antenna of female.

Fig. 4. Posterior antenna.

Fig. 5. Mandible and palp.

Fig. 6. Maxilla.

Fig. 7. Anterior foot-jaw.

Fig. 8. Posterior foot-jaw.

Fig. 9. Foot of first pair, female.

Fig. 10. Foot of second (and third) pair of female.

Fig. 11. Foot of fourth pair of female.

Figs. 12, 13. Fifth pair of feet of male (seen in different positions).

Fig. 14. Fifth pair of feet of female.

Fig. 15. Terminal spines of one of the swimming feet.

Fig. 16. Abdomen of male (monstrosity).

Fig. 17. The same (normal). 


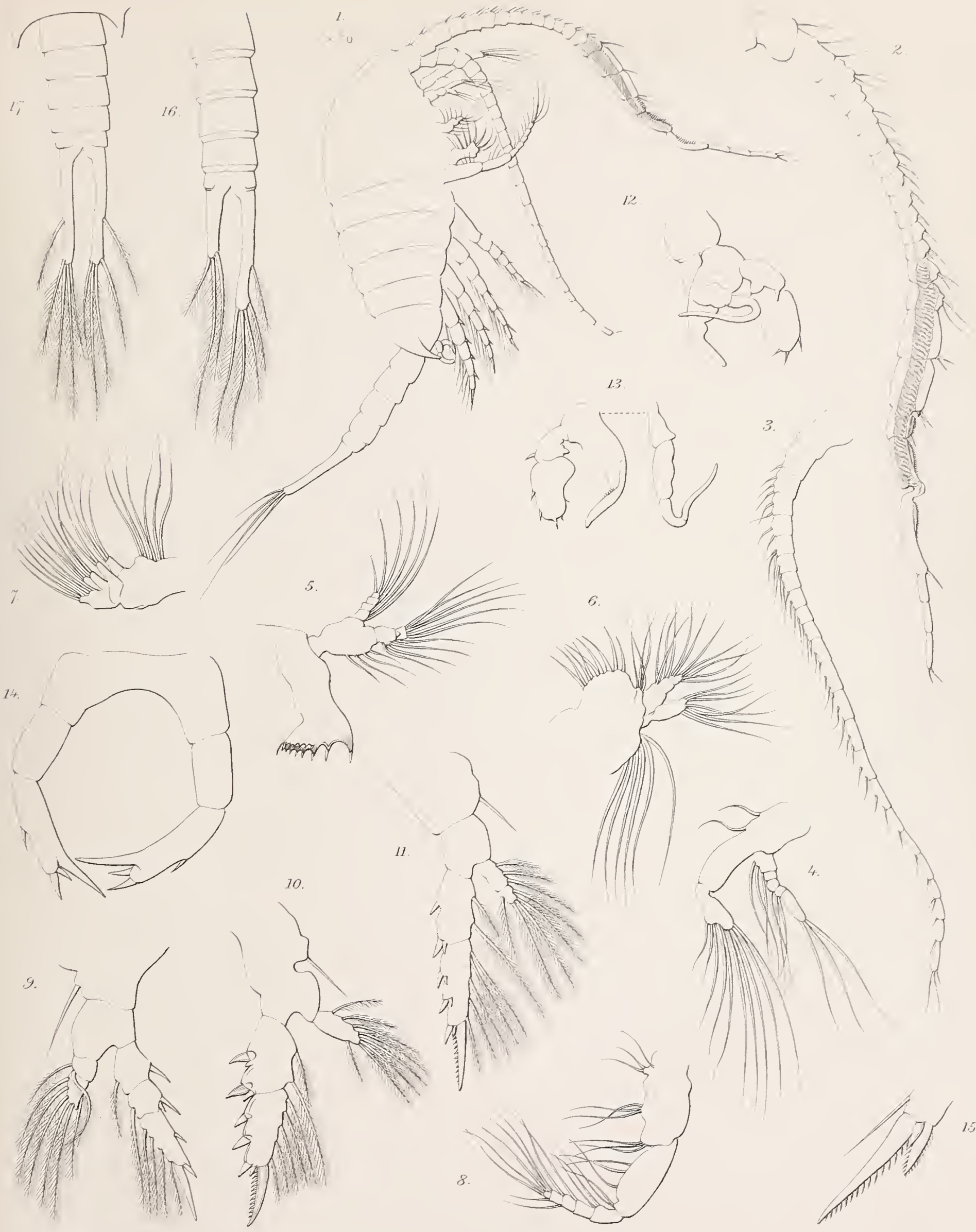



PLATE XXVI. 


\section{PLATE XXVI.}

Figs. 1-7. Centropages brachiatus (Dana).

Fig. 1. Female, seen from above, magnified 20 diameters.

Fig. 2. Base of anterior antenna of female.

Fig. 3. Right anterior antenna of male.

Fig. 4. Dentated joints of the same, more highly magnified.

Fig. 5. Foot of fifth pair, female.

Fig. 6. Right fifth foot of male.

Fig. 7. Left fifth foot of male.

Figs. 8-15. Pontella detruncata, Dana.

Fig. 8. Left anterior antenna of male.

Fig. 9. Right anterior antenna of male.

Figs. 10, 11. Denticulated plates of the same, more highly magnified.

Fig. 12. Fifth pair of feet of female.

Fig. 13. Fifth pair of feet of male.

Fig. 14. Abdomen of male.

Fig. 15. Abdomen of female. 


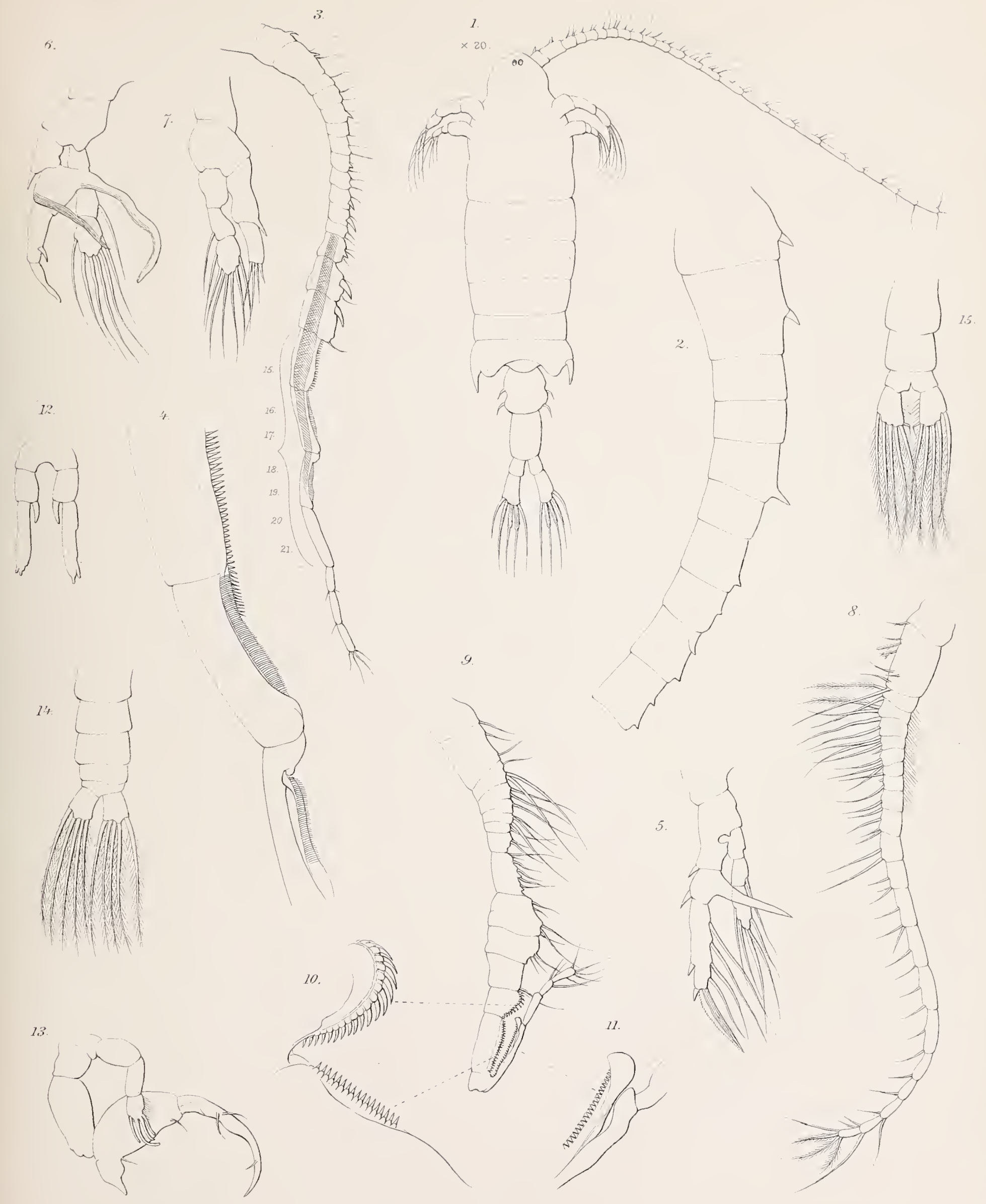

c. S. Brady, de] 


\section{PLATE XXVII.}

(ZOOL. CHALL. EXP,-PART XXII.—1883.) - Z. 


\section{PLATE XXVII.}

Centropages violaceus (Claus).

Fig. 1. Male, scen from above, magnified 40 diameters.

Fig. 2. Right anterior antenna of male.

Fig. 3. Hinge-joints of the same, more highly magnified.

Fig. 4. Anterior antenna of female.

Fig. 5. Mandible and palp.

Fig. 6. Maxilla.

Fig. 7. Anterior foot-jaw.

Fig. 8. Posterior foot-jaw.

Fig. 9. Foot of first pair.

Fig. 10. Foot of fourth pair.

Fig. 11. Foot of fifth pair of female.

Fig. 12. Fifth pair of feet of male.

Fig. 13. Extremity of outer branch of left fifth foot of male, more highly magnified.

Fig. 14. Last joints of abdomen and tail. 


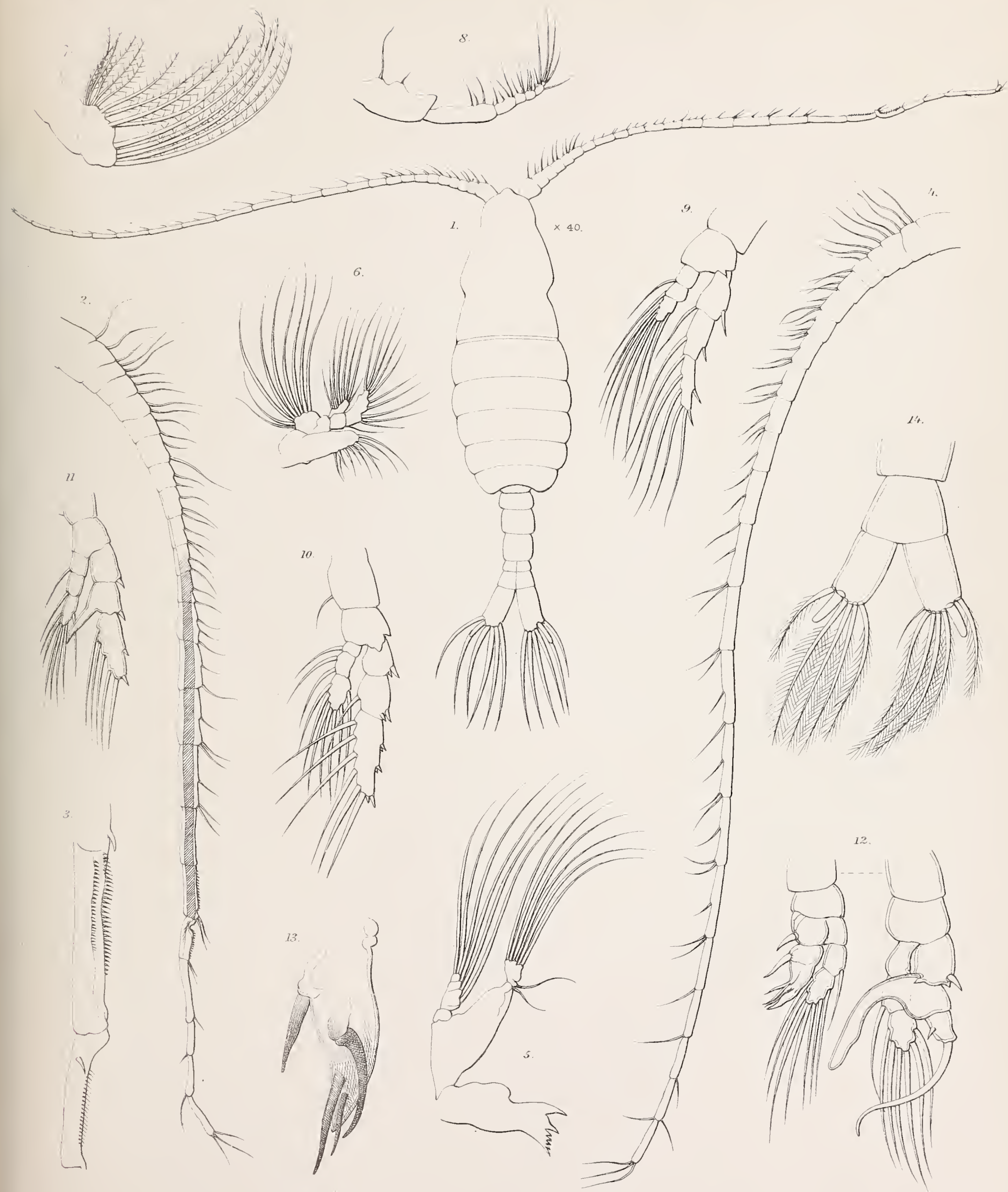



PLATE XXVIII. 


\section{PLATE XXVIII.}

Figs. 1-11. Centropages furcutus (Dana).

Fig. 1. Female, seen from right side, magnified 80 diameters.

Fig. 2. Cephalothorax of female, seen from above, magnified 50 diameters

Fig. 3. Right anterior antenna of male.

Fig. 4. Serrated plates of the same, more highly magnified.

Fig. 5. Foot of first pair.

Fig. 6. Foot of second pair.

Fig. 7. Foot of third pair.

Fig. 8. Fifth pair of feet of male.

Fig. 9. Foot of fifth pair, female.

Fig. 10. Terminal spines of one of the swimming feet.

Fig. 11. Abdomen of male.

Figs. 12-15. Candace truncata, Dana.

Fig. 12. Mandible and palp.

Fig. 13. Maxilla.

Fig. 14. Anterior foot-jaw.

Fig. 15. Posterior foot-jaw. 

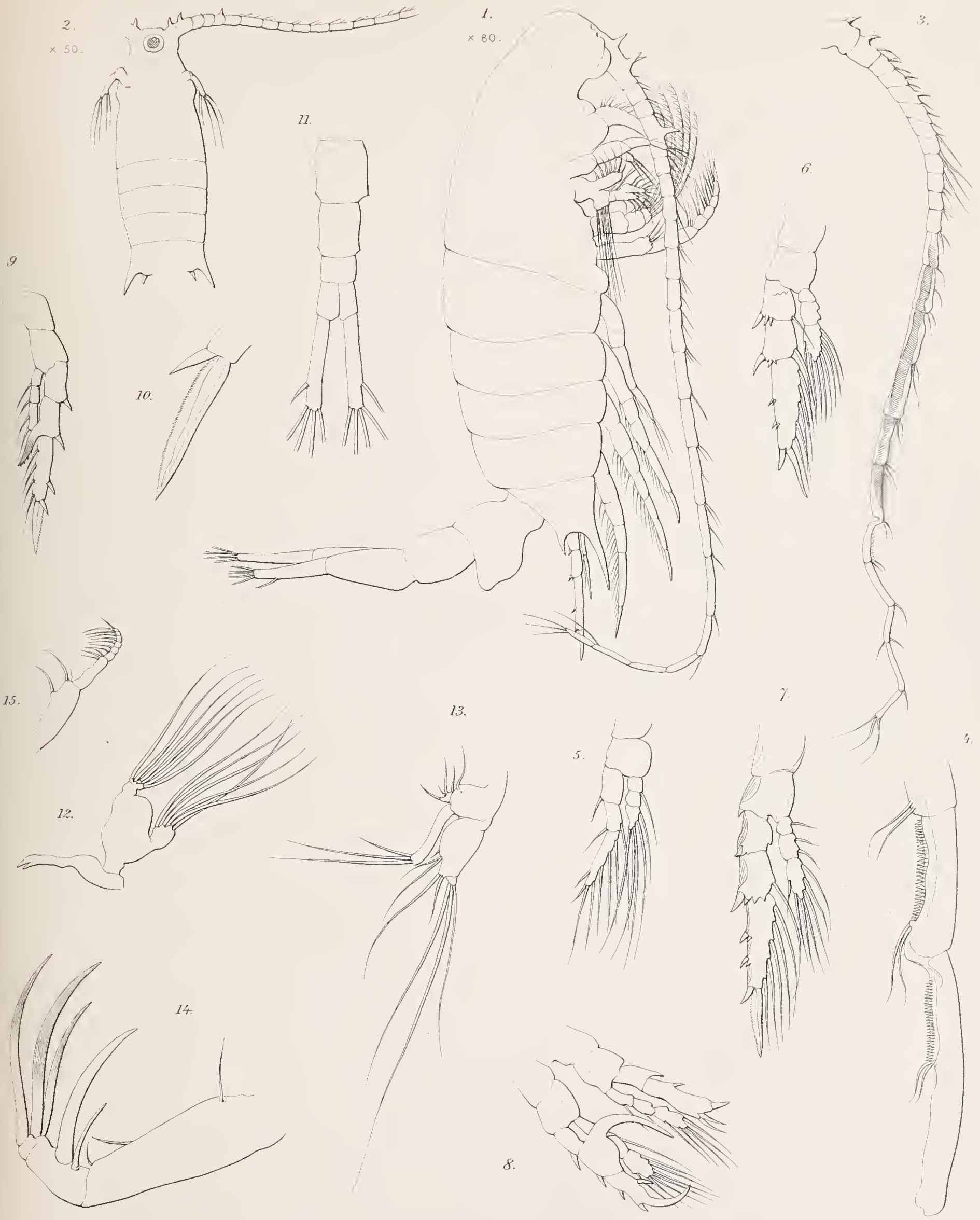

G.S.Brady, del. 

PLATE XXIX.

(ZOOL. CHALL. EXP.--PART XXII1-1883.)-Z. 


\section{PLATE XXIX.}

\section{Candace truncata, Dana.}

Fig. 1. Male, seen from above, magnified 40 diameters.

Fig. 2. Right anterior antenna of male.

Fig. 3. Anterior antenna of female.

Fig. 4. Basal joints of the same, more highly magnified.

Fig. 5. Posterior antenna.

Fig. 6. Foot of first pair.

Fig. 7. Foot of third pair, female.

Fig. 8. Outer branch of third foot, male.

Fig. 9. Fifth pair of feet of male.

Fig. 10. Fifth pair of feet of female.

Fig. 11. Fifth pair of feet of female (var. bispinosa).

Fig. 12. Apex of the same, more highly magnified.

Fig. 13. Abdomen of female.

Fig. 14. The same (variety, or young ?). 
Copepoda, P1.XXIX.

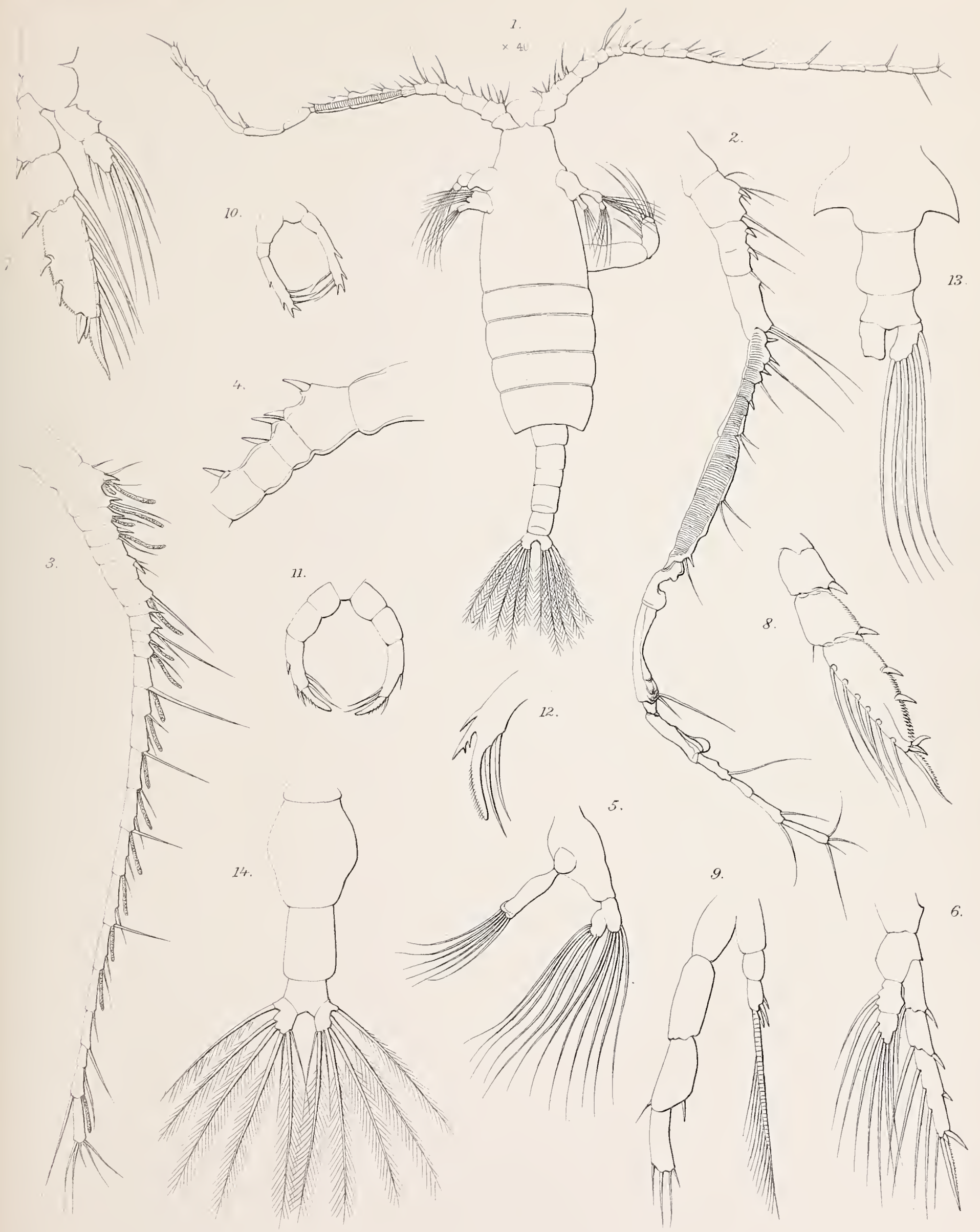



PLA'TE XXX. 


\section{PLATE XXX.}

\section{Candace pectinata, Brady.}

Fig. 1. Female, seen from above.

Fig. 2. Female, seen from right side, both magnified 32 diameters.

Fig. 3. Anterior antenna of female.

Fig. 4. Right anterior antenna of male.

Fig. 5. Basal joints of the same.

Fig. 6. Pectinated joints of the same.

Fig. 7. One of the swimming feet.

Fig. 8. End of outer branch of third foot.

Figs. 9, 10. Fifth pair of feet of male, two different specimens.

Figs. 11, 12. Fifth pair of feet of female, two different specimens.

Fig. 13. Abdomen of male. wentea... 


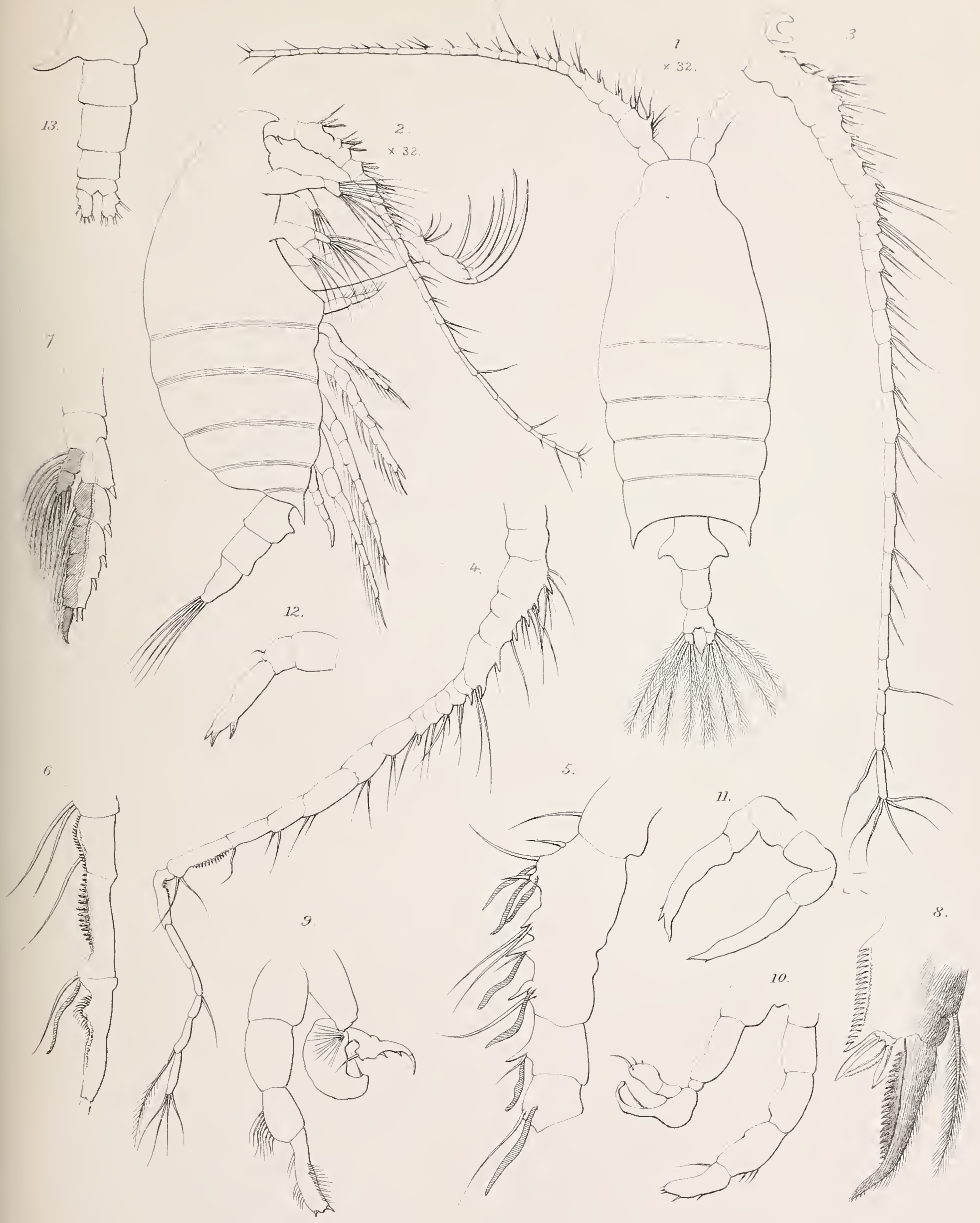

G S.Brady del

CANDACE PECTINATA, Brady. 



\section{PLATE XXXI.}

(ZOOL。 CHALL, EXP, - PART XXII. -1883.)-Z 


\section{PLATE XXXI.}

Fig. 1. Acartia denticonis, 11. sp.

Fig. 1. Female, seen from above, magnified 80 diameters.

Figs. 2-9. Candace pachydactyla, Dana.

Fig. 2. Anterior antenna of female.

Fig. 3. Anterior antenna of male.

Fig. 4. Peetinated joints of the same, more highly magnified.

Fig. 5. Outer braneh of one of the swimming feet.

Fig. 6. Fifth pair of feet of male.

Fig. 7. The same, from an immature specimen.

Fig. 8. Fifth pair of feet of female.

Fig. 9. Abdomen of male.

Figs. 10-12. Corynura barbata, n. gen. and sp.

Fig. 10. Anterior antenna of female.

Fig. 11. Fifth pair of feet.

Fig. 12. One of the eaudal stylets (with last abdominal rings).

Figs. 13, 14. Pleuromma abdominale (Lubboek).

Fig. 13. Base of anterior antenna of female.

Fig. 14. Posterior antenna. 

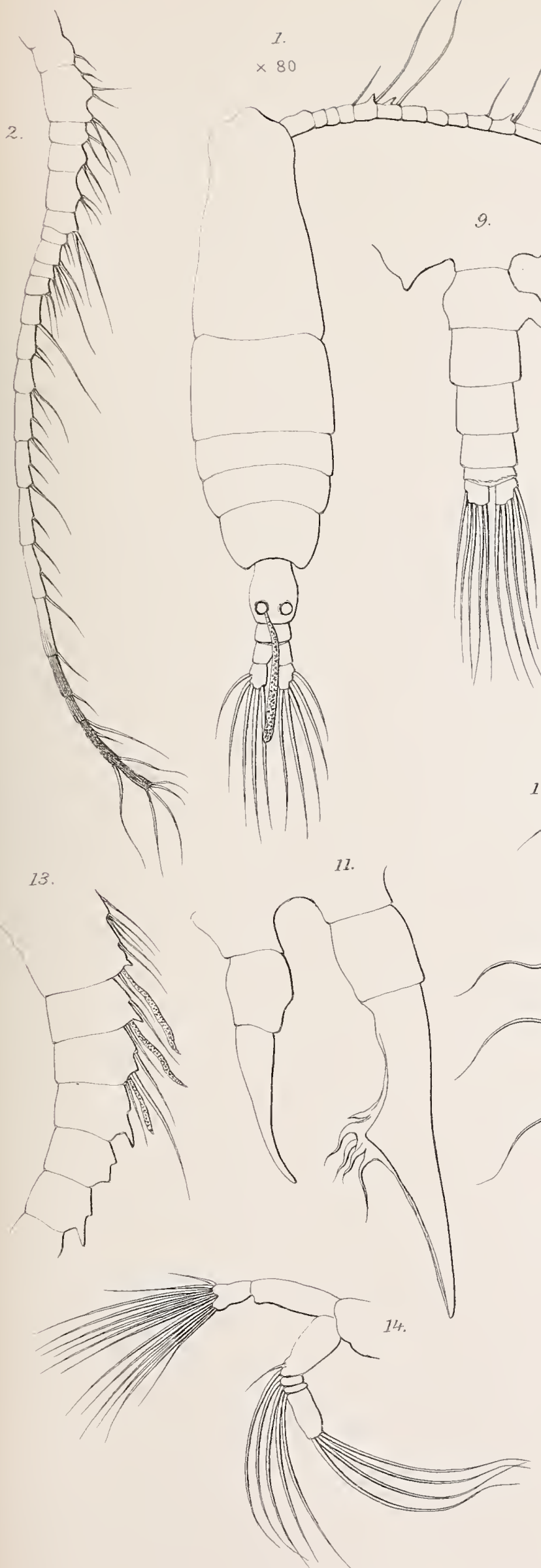
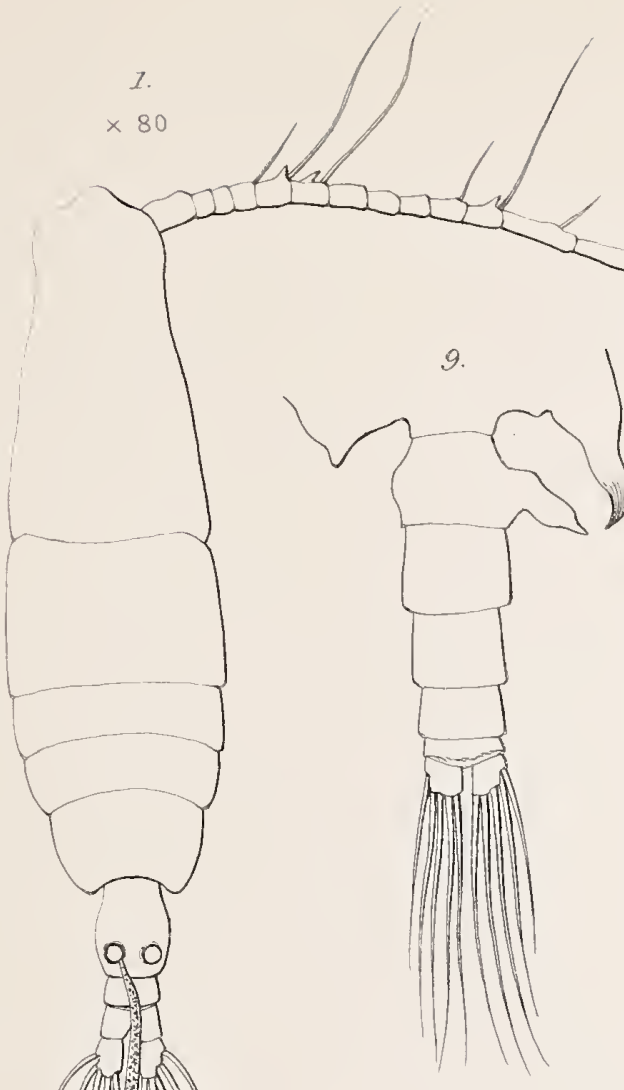

2
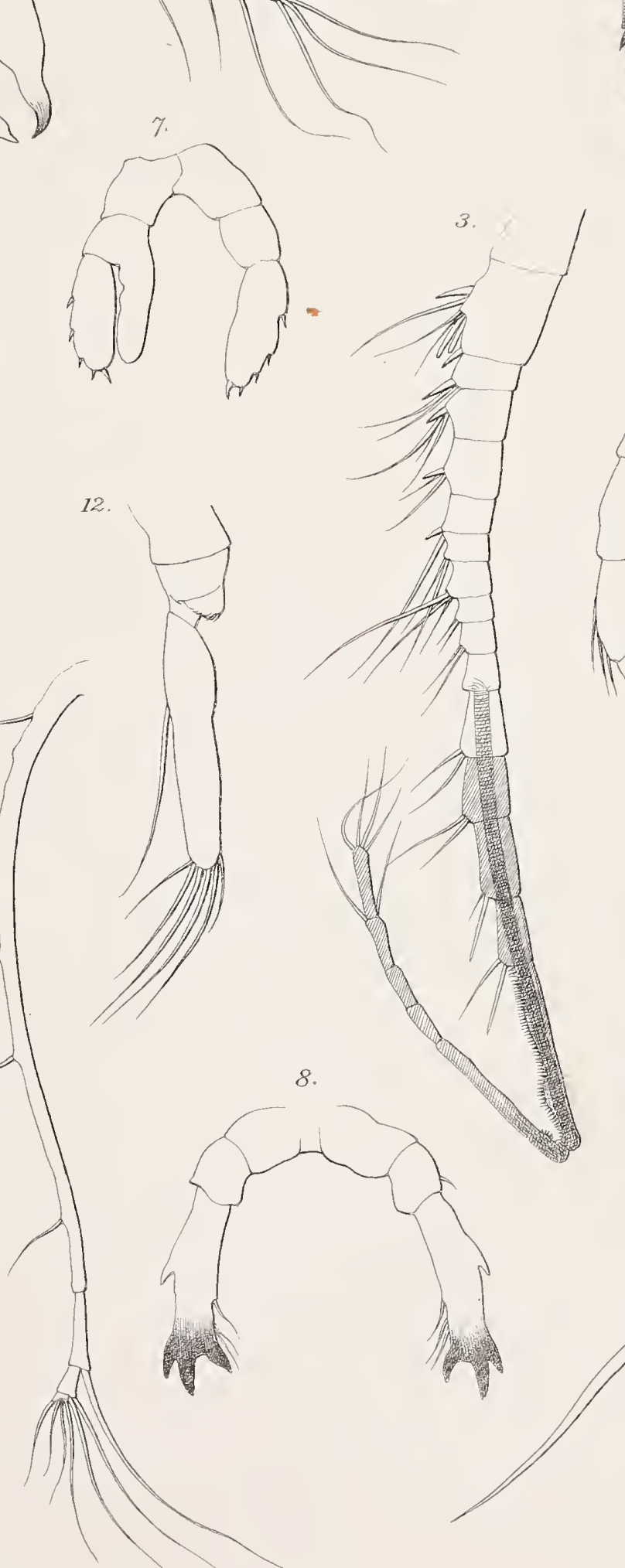

0.

an?

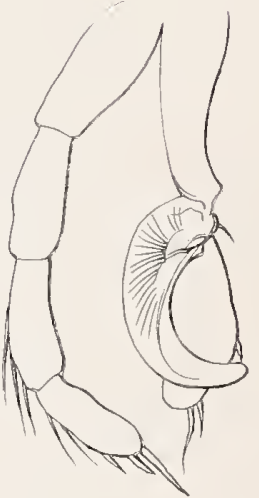



PLATE XXXII. 


\section{PLATE XXXII.}

Figs. 1-11. Acartia laxa, Dana.

Fig. 1. Female, magnified 40 diameters.

Fig. 2. Anterior antenna of female.

Fig. 3. Posterior antenna.

Fig. 4. Mandible and palp.

Fig. 5. Maxilla.

Fig. 6. Anterior foot-jaw.

Fig. 7. Posterior foot-jaw.

Fig. 8. Foot of first pair.

Fig. 9. Outer branch of one of the swimming feet.

Fig. 10. Fifth pair of feet of female.

Fig. 11 Abdomen of female.

Figs. 12-17. Acartia denticomis, n. sp.

Fig. 12. Anterior antenna of male.

Fig. 13. Posterior foot-jaw.

Fig. 14. Foot of third pair.

Fig. 15. Fifth foot of male (one side ${ }^{\mathrm{z}}$ only.)

Fig. 16. Fiftl pair of feet of female.

Fig. 17. Abdomen of male. 


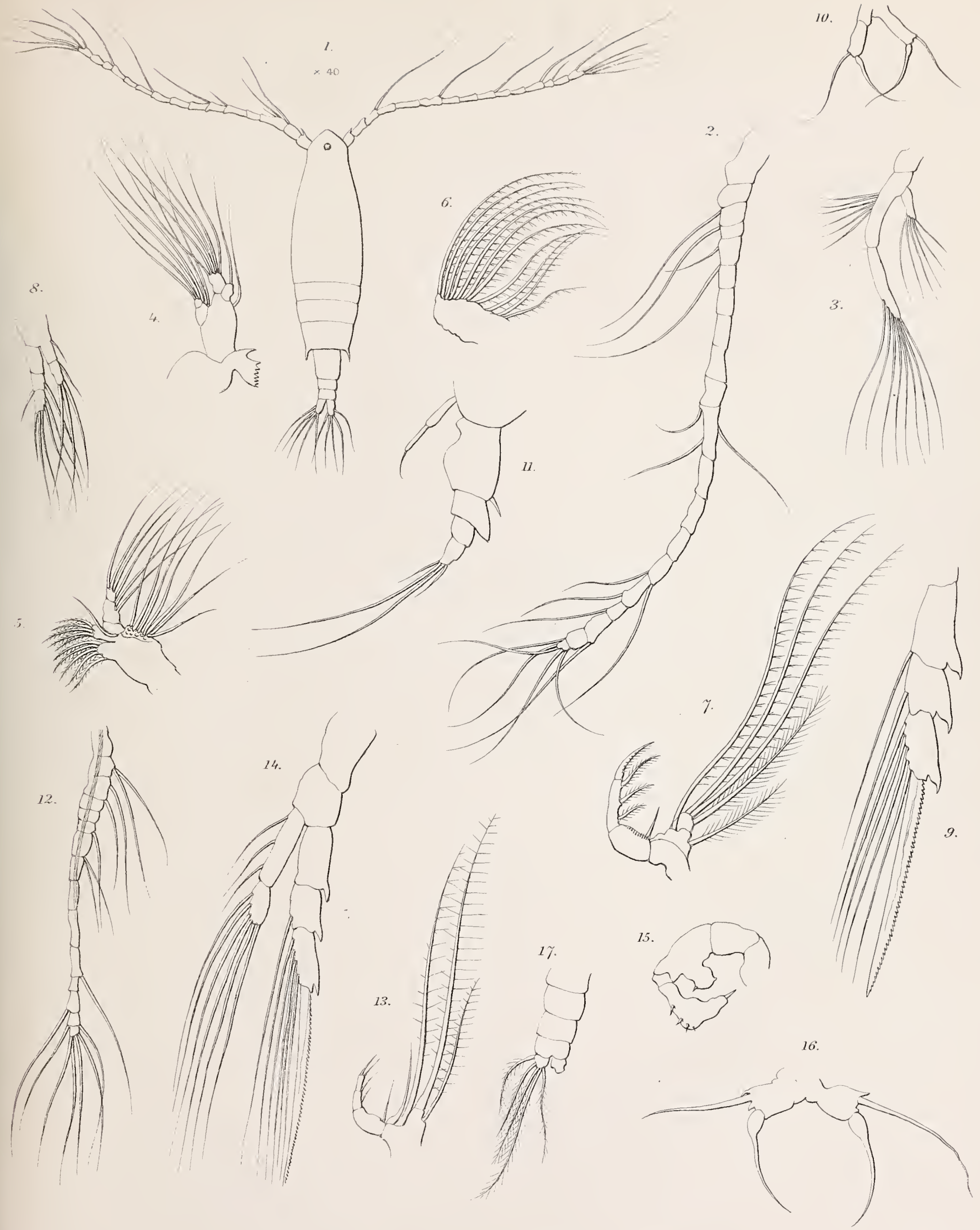

S Prady, del. 

PLATE XXXIII.

(ZOOL. CALL. EXP. -PART XXIIL-1883.)-Z. 


\section{PLATE XXXIII.}

Corynurce gracitis, $\mathrm{n}$. gen. and sp.

Fig. 1. Male, seen from below.

Fig. 2. Female, seen from right side; both magnified 50 diameters.

Fig. 3. Anterior antenna of female.

Fig. 4. Denticulated portion of right male antenna.

Fig. 5. Posterior antenna.

Fig. 6. Mandible and palp.

Fig. 7. Maxilla.

Fig. 8. Anterior foot-jaw.

Fig. 9. Posterior foot-jaw.

Fig. 10. One of the swimming feet.

Fig. 11. Fifth pair of feet of male.

Fig. 12. Fifth pair of feet of female.

Fig. 13. Abdomen and tail of female, seen from front.

Fig. 14. The same seen laterally. 
The Vovage of H M. S. Challenger"

Copepoda. H.XXXIII.

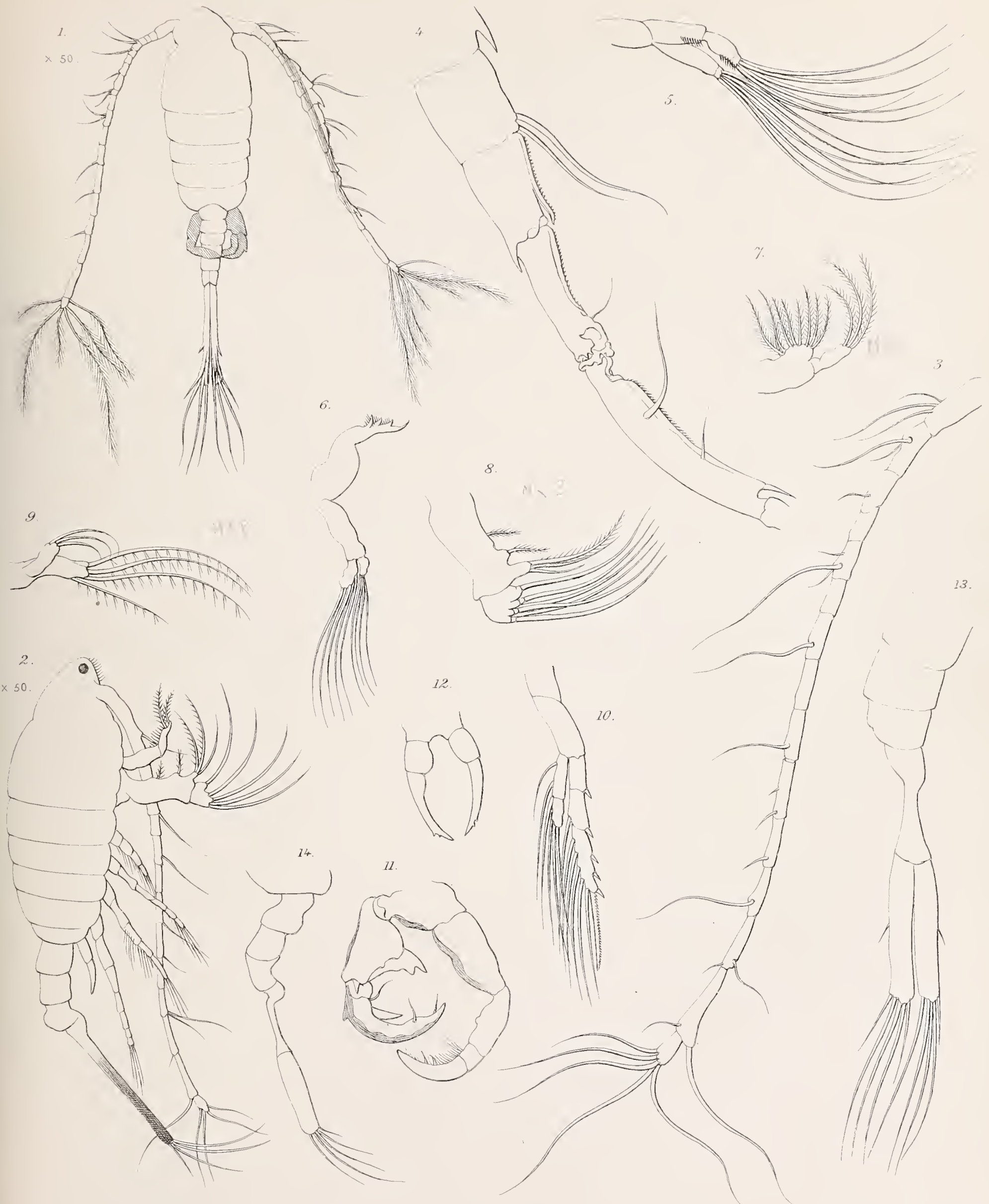



PLATE XXXIV. 


\section{PLATE XXXIV.}

Figs. 1-9. Calanopia elliptica, Dana.

Fig. 1. Female, magnified 50 diameters.

Fig. 2. Anterior antenna of female.

Fig. 3. Right anterior antenna of male, with rostrum and eyes.

Fig. 4. Denticulated joint of same, more highly magnified.

Fig. 5. Mandible and palp.

Fig. 6. Fifth pair of feet of female.

Fig. 7. Fifth pair of feet of male.

Fig. 8. Extremity of left fifth foot of male, more highly magnified.

Fig. 9. Abdomen and tail of male.

Figs. 10-13. Pontellopsis villosa, n. gen. and sp.

Fig. 10. Posterior antenna.

Fig. 11. Maxilla.

Fig. 12. Anterior foot-jaw.

Fig. 13. Posterior foot-jaw. 


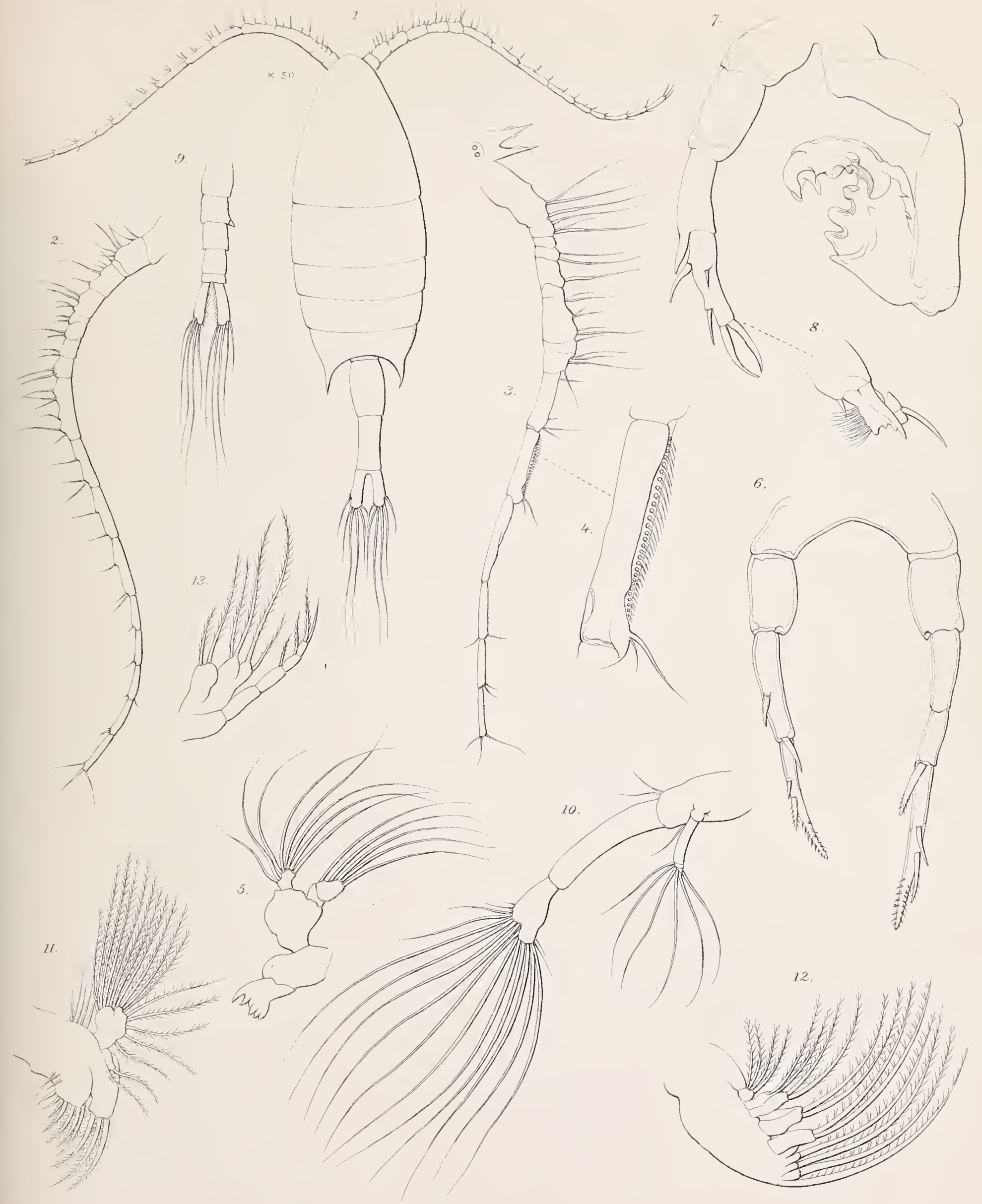

- S Brady del 



\section{PIAATE XXXV.}

(zoot. CHaLl. FXP.-PART XXIII.-1883.)-Z. 


\section{PLATE XXXV.}

Figs. 1-13. Pontelle acutifrons (Dana).

Fig. 1. Male, seen from above, magnified 16 diameters.

Fig. 2. Forehead and rostrum with superior eyes.

Fig. 3. Left anterior antenna of male.

Fig. 4. Right anterior antenna of male.

Fig. 5. Denticulated joints of the same, more highly magnified.

Figs. 6, 7. Teeth of the upper and lower denticulated plates.

Fig. 8. Outer brancli of one of the swimming feet.

Fig. 9. Fifth pair of feet of female.

Fig. 10. Fifth pair of feet of male.

Fig. 11. Appendage of the same, more highly magnitied.

Fig. 12. Abdomen of female.

Fig. 13. Abdomen of male.

Figs. 14-20. Pontellopsis villosa, n. gen. and sp.

Fig. 14. Female, seen from above, magnified 20 diameters.

Fig. 15. Anterior antenna of same.

Fig. 16. Mandible and palp.

Fig. 17. Foot of first pair.

Fig. 18. Foot of second pair.

Fig. 19. Fifth pair of feet of female.

Fig. 20. Abdomen of female. 


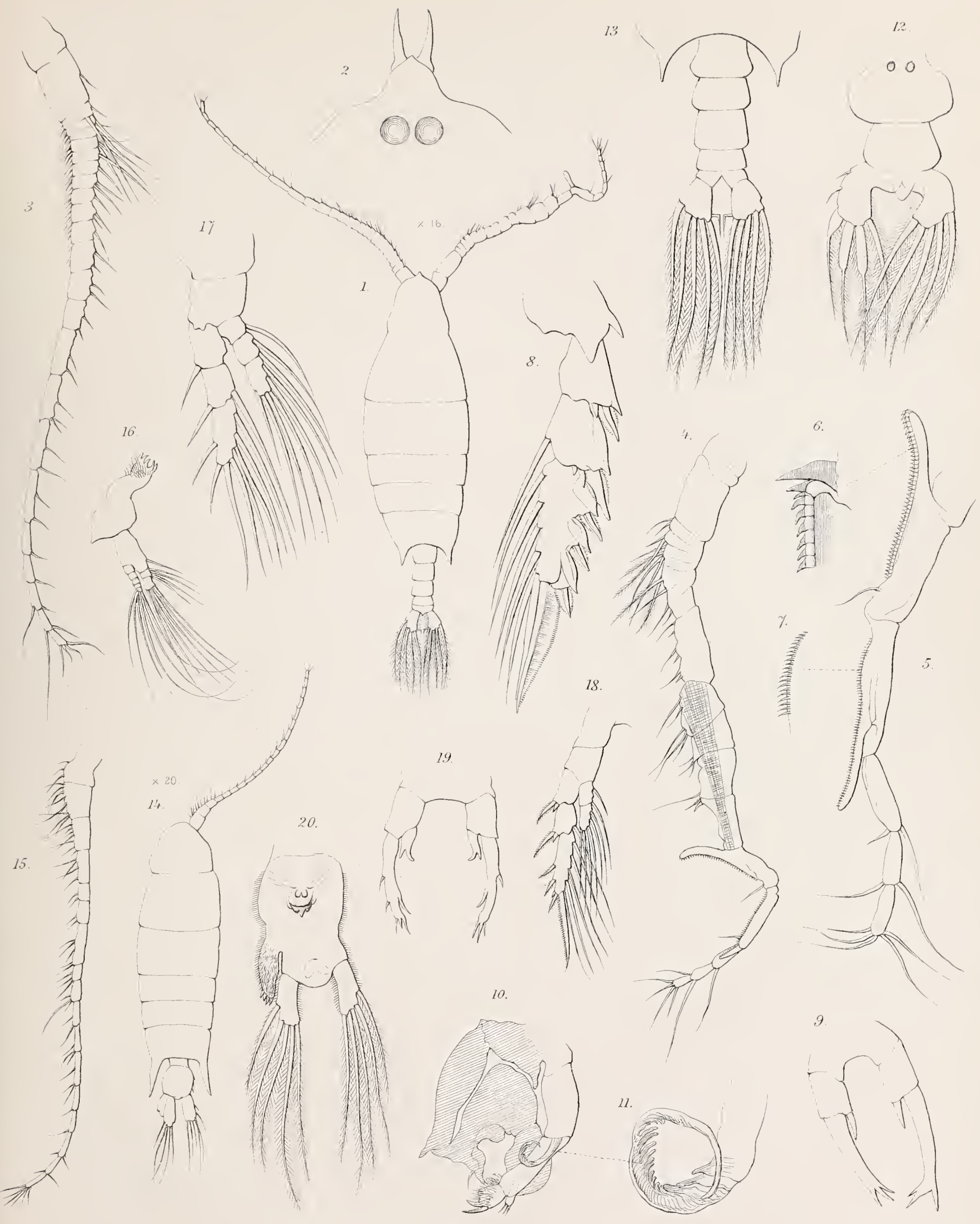

G.S. Brady del. 

PLATE XXXVI, 


\section{PLATE XXXVI.}

\section{Pontella acuta (Dana).}

Fig. 1. Female, seen from right side; magnified 32 diameters.

Fig. 2. Anterior antenna of left side (male).

Fig. 3. Anterior antenna of right side (male).

Figs. 4, 5. Portions of denticulated plates of same, more highly magnified.

Fig. 6. Maxilla.

Fig. 7. Posterior foot-jaw.

Fig. 8. Fifth pair of feet of male.

Fig. 9. Fifth pair of feet of female.

Fig. 10. Abdomen and posterior thoracic angles of male.

Fig. 11. The same structures of female.

Fig. 12. Second and third tail setæ of female, more highly magnified. 


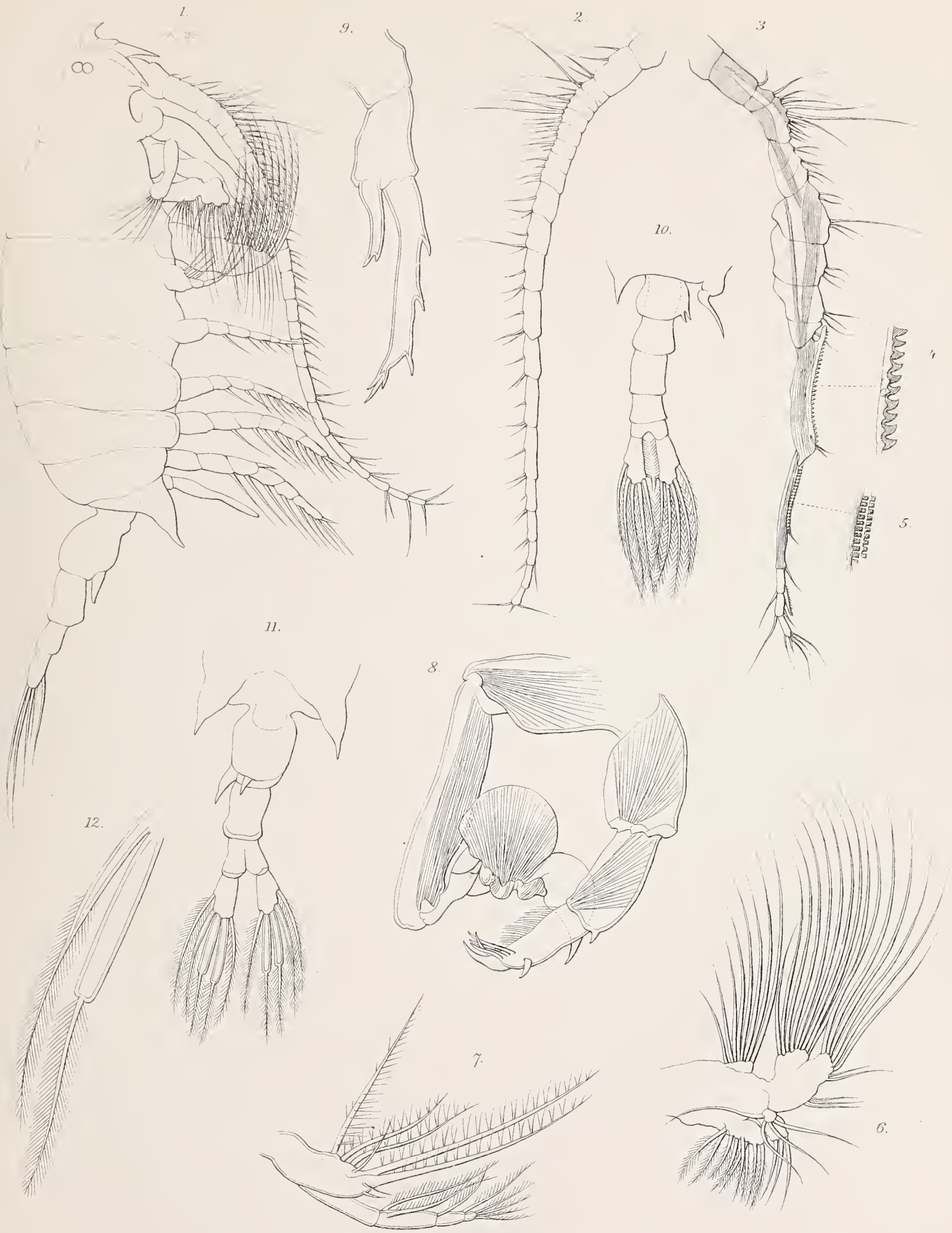



PLATE XXXVII 


\section{PLATE XXXVII.}

\section{Pontella plumata (Dana).}

Fig. 1. Female, seen from left side; magnified 40 diameters.

Fig. 2. Anterior antenna of female.

Fig. 3. Right anterior antenna of male.

Fig. 4. Posterior antenna of female.

Fig. 5. Mandible of female.

Fig. 6. Foot of first pair.

Fig. 7. Foot of third pair.

Fig. 8. Fifth pair of feet of female.

Fig. 9. Fifth pair of feet of male.

Fig. 10. Abdomen of female.

Fig. 11. Abdomen of male. 


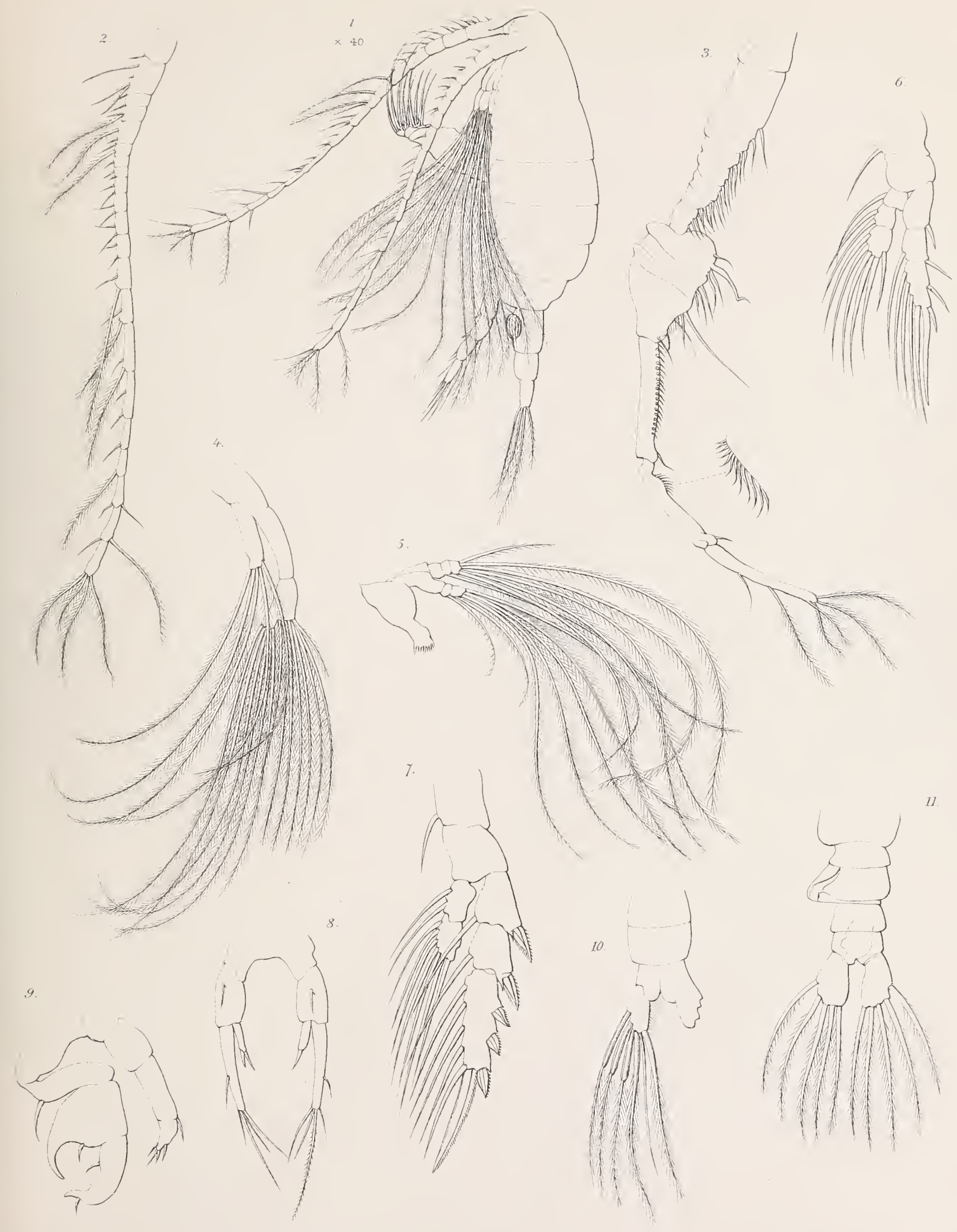

PONTELLA PLUMATA, Dana. 



\section{PLATE XXXVIII.}




\section{PLATE XXXVIII.}

Figs. 1-6. Pontella lavidentata, n. sp.

Fig. 1. Male, seen from above; magnified 50 diameters.

Fig. 2. Right anterior antenna of the same.

Fig. 3. Serrated plates of the same, more highly magnified.

Fig. 4. One of the swimming feet.

Fig. 5. Fifth pair of feet of male.

Fig. 6. End of left foot of the same, more highly magnified.

Figs. 7-14. Pontella elephas, n. sp.

Fig. 7. Male, seen from above; magnified 30 diameters.

Fig. 8. Anterior antenna of female.

Fig. 9. Right anterior antenna of male.

Figs. 10, 11. Teeth of denticulated plate of the same, more highly magnified.

Fig. 12. Fifth pair of feet of female.

Fig. 13. Fifth pair of feet of male.

Fig. 14. Abdomen of female. 


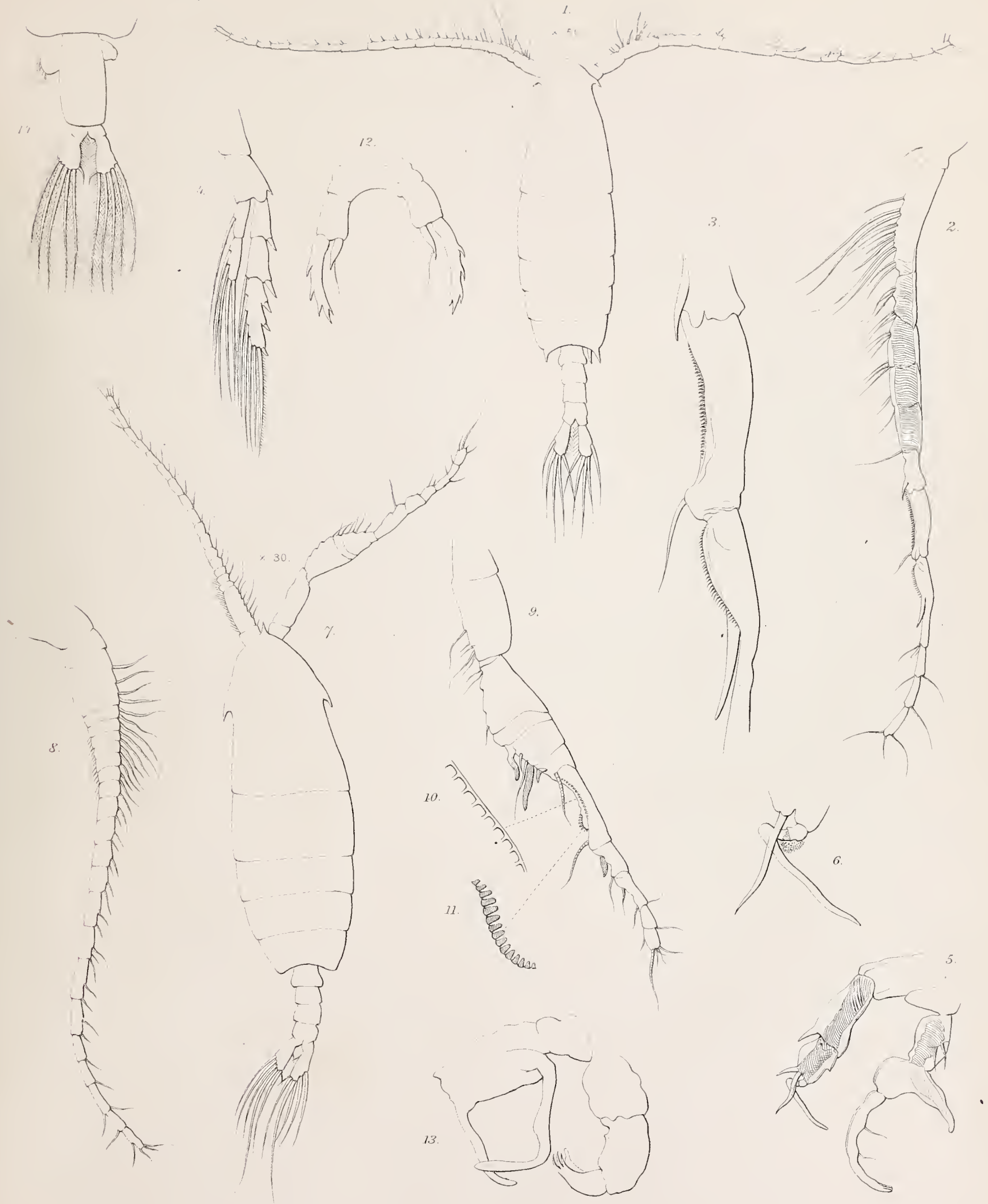

G.S Brady del 

PLATE XXXIX.

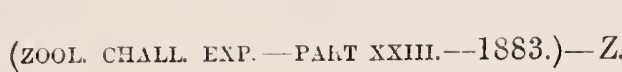




\section{PLATE XXXIX.}

Pontella kröyeri, n. sp.

Fig. 1. Female, seen from above; magnified 40 diameters.

Fig. 2. Anterior antenna of female.

Fig. 3. Right anterior antenna of male.

Fig. 4. Portion of teeth of the same, more highly magnified.

Fig. 5. Posterior antenua.

Fig. 6. Mandible and palp.

Fig. 7. Maxilla.

Fig. 8. Anterior foot-jaw.

Fig. 9. Posterior foot-jaw.

Fig. 10. Fifth pair of feet of female.

Fig. 11. Fifth pair of feet of male.

Fig. 12. Terminal papillæ, \&c., of fifth foot of left side.

Fig. 13. The same of another specimen.

Fig. 14. Posterior thoracic segments and abdomen of female (ventral aspect).

Fig. 15. The same (lateral aspect).

Figs. 16, 17. Female abdomen-other specimens.

Fig. 18. Male abdomen, seen laterally.

Fig. 19. The same, seen from front. 

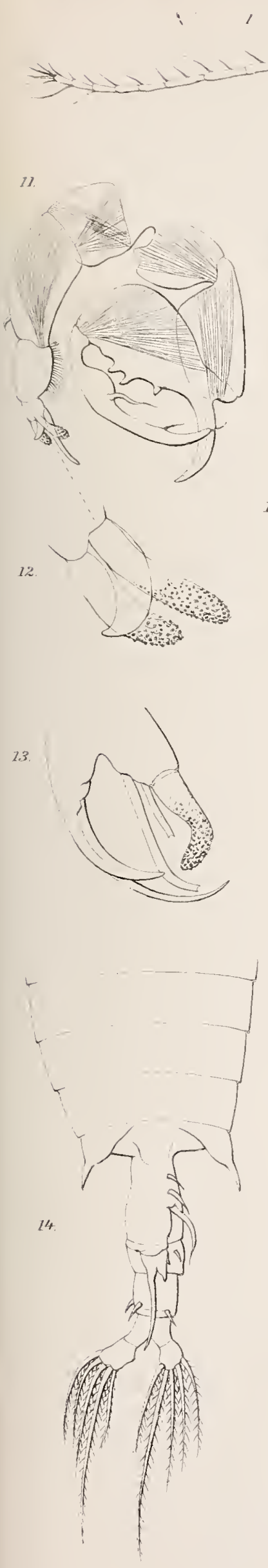
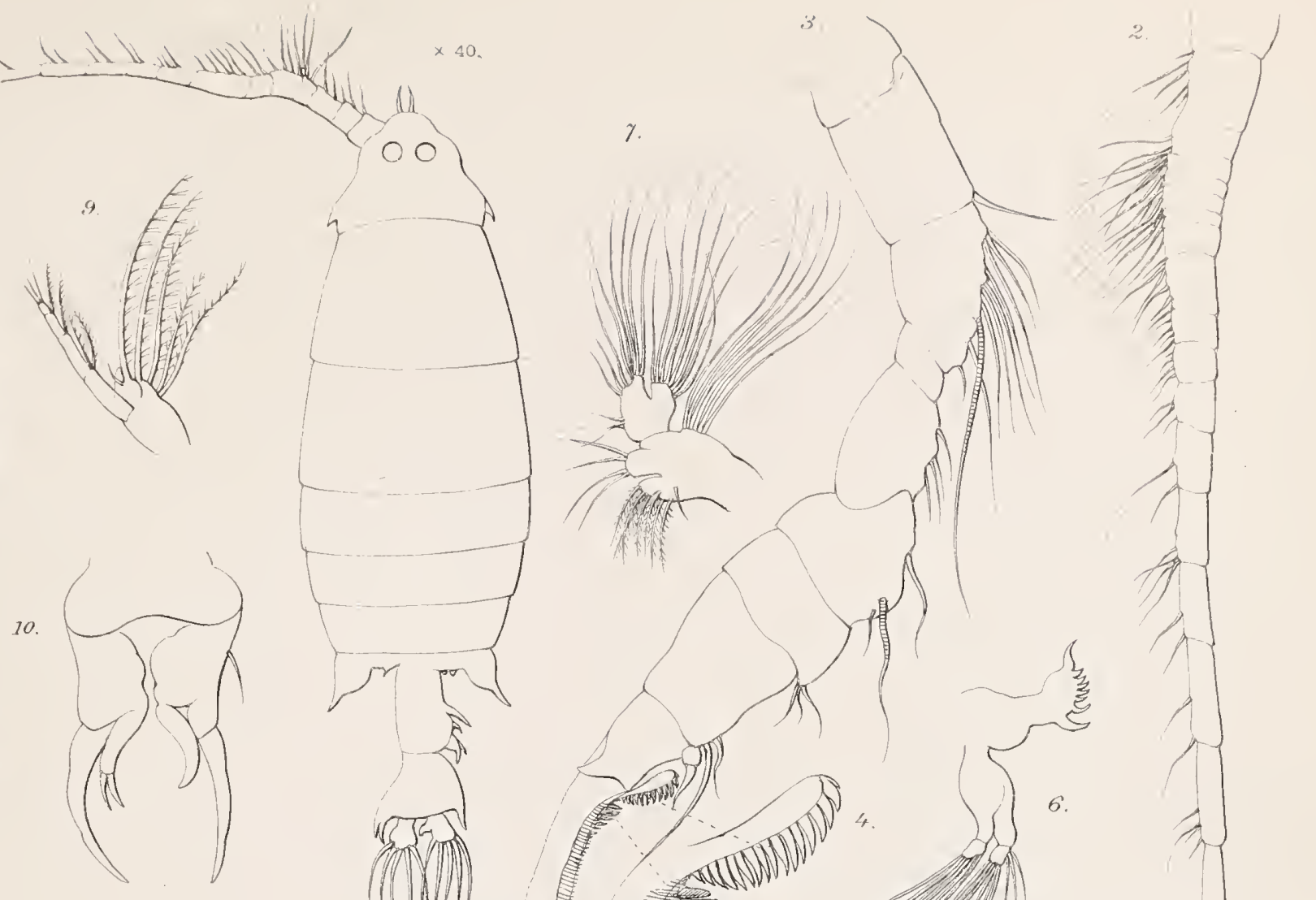

Y 



\section{PLATE XL.}


PLATE XL.

Figs. 1-10. Oithona challengerii, n. sp.

Fig. 1. Female, seen from above; magnified 50 diameters.

Fig. 2. Rostrum.

Fig. 3. Posterior antenna.

Fig. 4. Maxilla.

Fig. 5. Anterior foot-jaw.

Fig. 6. Posterior foot-jaw.

Fig. 7. Foot of first pair.

Fig. 8. Foot of fourth pair.

Figs. 9, 10. Basal portions of the two setæ of fifth foot.

Figs. 11-15. Zaus spinatus, Goodsir.

Fig. 11. Anterior antenna.

Fig. 12. Mandible and palp.

Fig. 13. Foot of first pair.

Fig. 14. One of the swimming feet.

Fig. 15. Foot of fifth pair. 


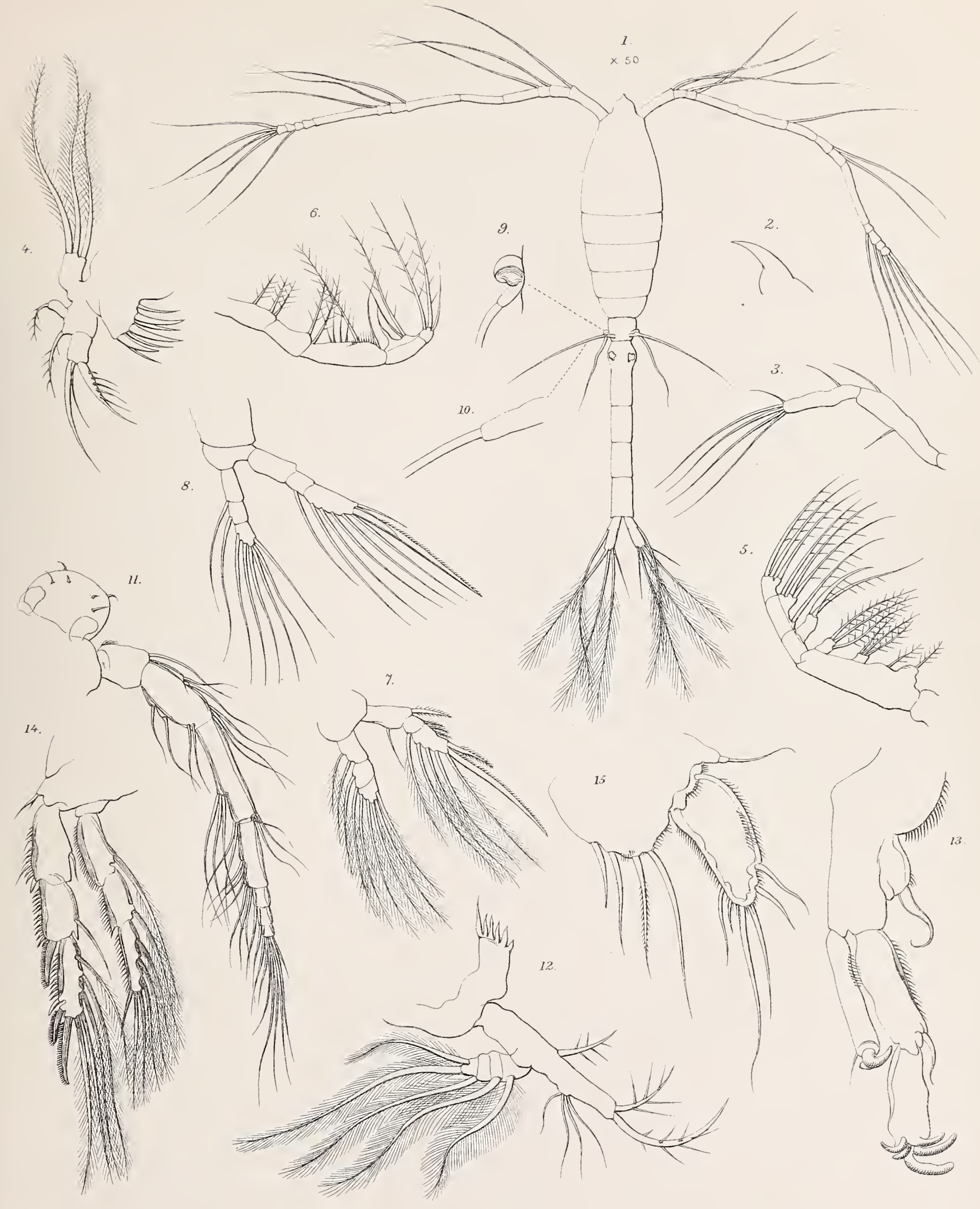



PLATE XLI.

(ZOOL. CHALL. EXP.-PART XXII.-1883.)-Z. 


\section{PLATE XLI.}

Figs. 1-12. Machairopus idyoides, n, gen. and sp.

Fig. 1. Female, seen from above.

Fig, 2. Male seen from side; both magnified 50 diameters.

Fig. 3. Anterior antenna of female.

Fig. 4. Posterior antenna.

Fig. 5. Mandible and palp.

Fig. 6. Anterior foot-jaw.

Fig. 7. Posterior foot-jaw.

Fig. 8. Foot of first pair.

Fig. 9. One of the following pairs of swimming feet.

Fig. 10. Foot of fifth pair, female.

Fig. 11. Abdomen of female.

Fig. 12. Abdomen of male.

Figs. 13-17. Zaus spinatus, Goodsir.

Fig. 13. Female, magnified 50 diameters.

Fig. 14. Posterior antenna.

Fig. 15. Anterior foot-jaw.

Fig. 16. Posterior foot-jaw.

Fig. 17. Abdomen and tail. 


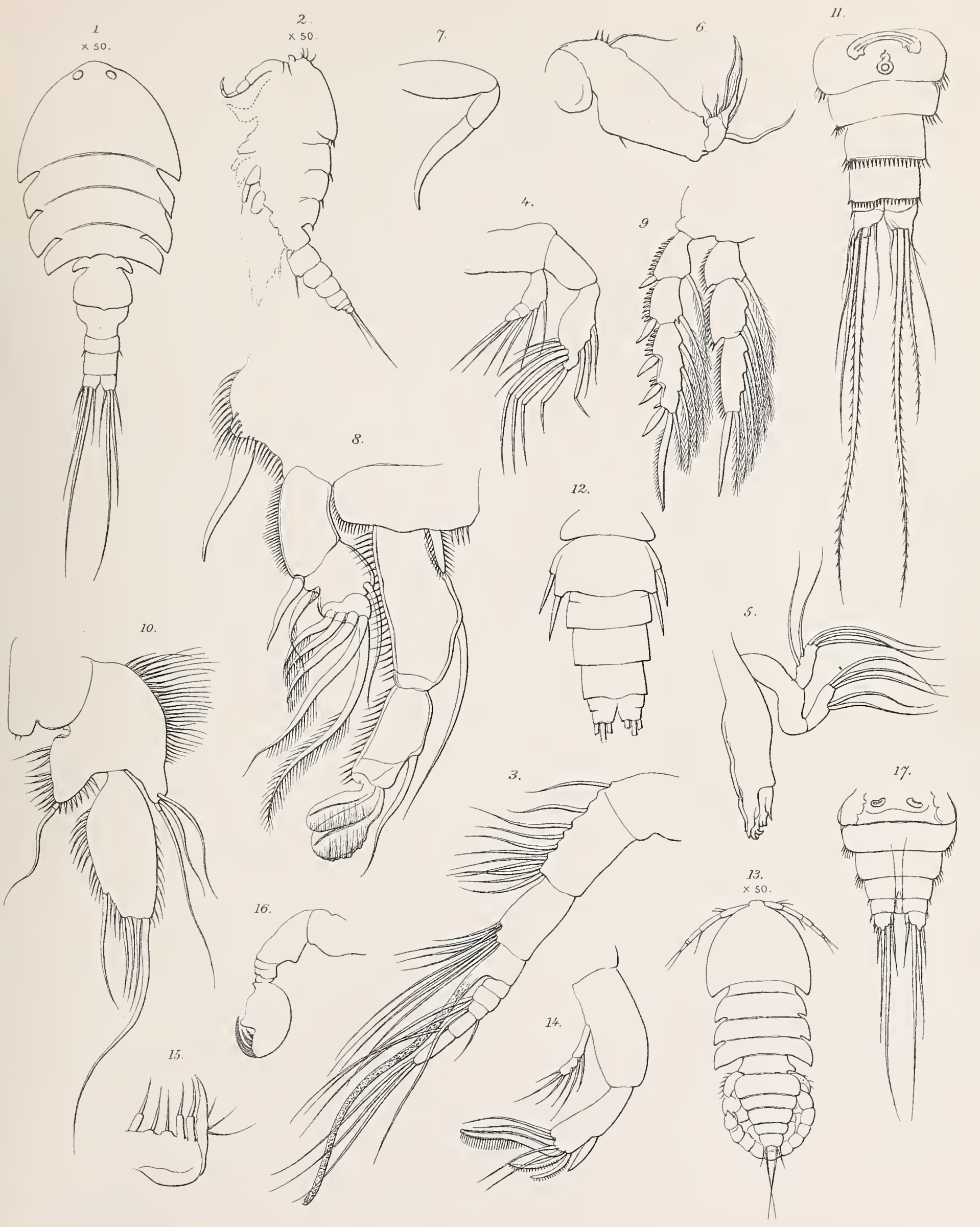

G. S. Brady del. 

PLA'I'E XLIII. 


\section{PLATE XLII.}

Figs. 1-8. Pseudothalestris imbricata, n. gen. and sp.

Fig. 1. Anterior antenna of male.

Fig. 2. Inner branch of posterior antenna.

Fig. 3. Posterior foot-jaw.

Fig. 4. Foot of first pair.

Fig. 5. Foot of second pair.

Fig. 6. Foot of third and fourth pairs.

Fig. 7. Foot of fifth pair.

Fig. 8. Abdomen and tail.

Figs. 9-16. Goniopsyllus rostratus, n. gen. and sp.

Fig. 9. Male, seen from the left side.

Fig. 10. The same, seen from above; both magnified 80 diameters.

Fig. 11. Anterior antenna.

Fig. 12. Posterior antenna.

Fig. 13. a, Maxilla; $b$, anterior foot-jaw.

Fig. 14. Posterior foot-jaw.

Fig. 15. One of the swimming feet.

Fig. 16. Fifth pair of feet. 


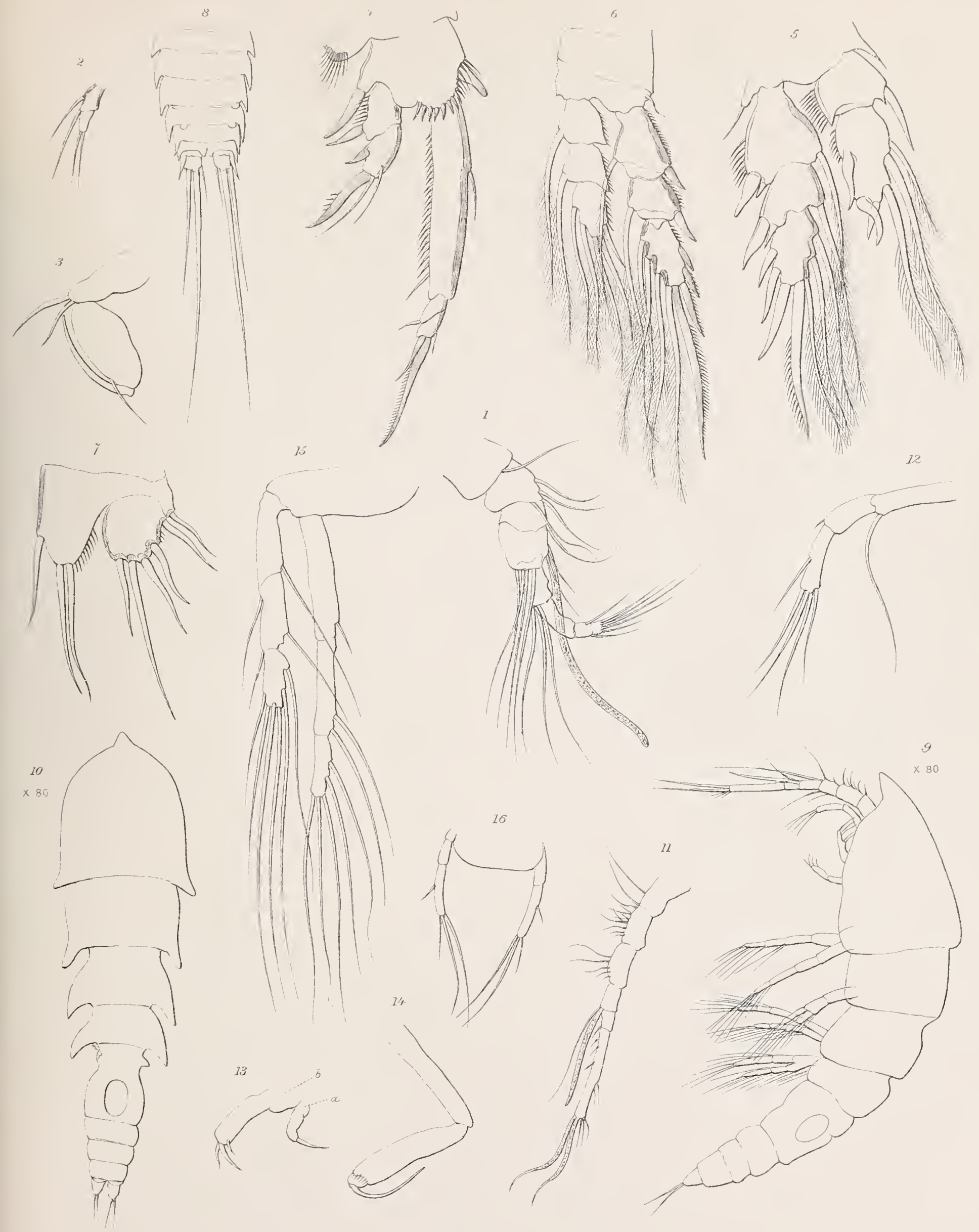




\section{PLATE XLIII.}

(ZOOL. CHALL. EXP.-PART XXIII.-1883.) - Z . 


\section{PLATE XLIII.}

Figs. 1-16. Miracia efferata, Dana.

Fig. 1. Male, seen from right side; magnified 55 diameters.

Fig. 2. Female, seen from left side; magnified 50 diameters.

Fig. 3. Anterior antenna of male.

Fig. 4. Anterior antenna of female.

Fig. 5. Posterior antenna.

Fig. 6. Mandible.

Fig. 7. Maxilla.

Fig. 8. Anterior foot-jaw.

Fig. 9. Posterior foot-jaw.

Fig. 10. Foot of first pair.

Fig. 11. Inner branch of second foot of male.

Fig. 12. Foot of third and fourth pairs.

Fig. 13. Fifth foot, male.

Fig. 14. Fifth foot, female.

Fig. 15. Abdomen of male.

Fig. 16. Corneal lenses. 


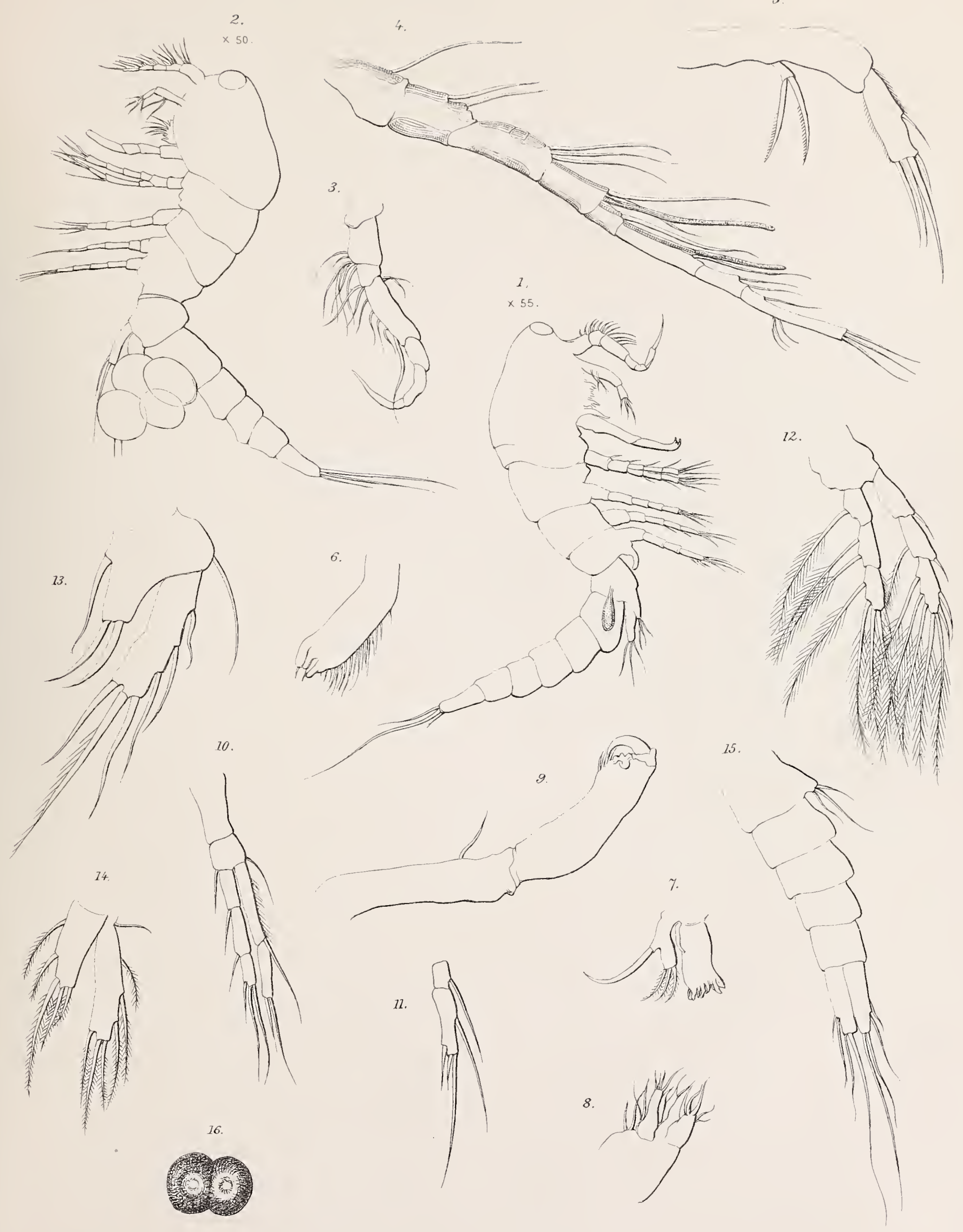



PLATE XLIV. 


\section{PLATE XLIV.}

Pontostratiotes abyssicola, 11. genl. and sp.

Fig. 1. Animal, seen from above.

Fig. 2. The same, seen from left side; both magnified 40 diameters.

Fig. 3. Spines of cephalothorax.

Fig. 4. Anterior antenna.

Fig. 5. Posterior antenna.

Fig. 6. Mandible and palp.

Fig. 7. Maxilla.

Fig. 8. Anterior foot-jaw.

Fig. 9. Posterior foot-jaw.

Fig. 10. One of the swimming feet.

Fig. 11. Fiftlı pair of feet. 


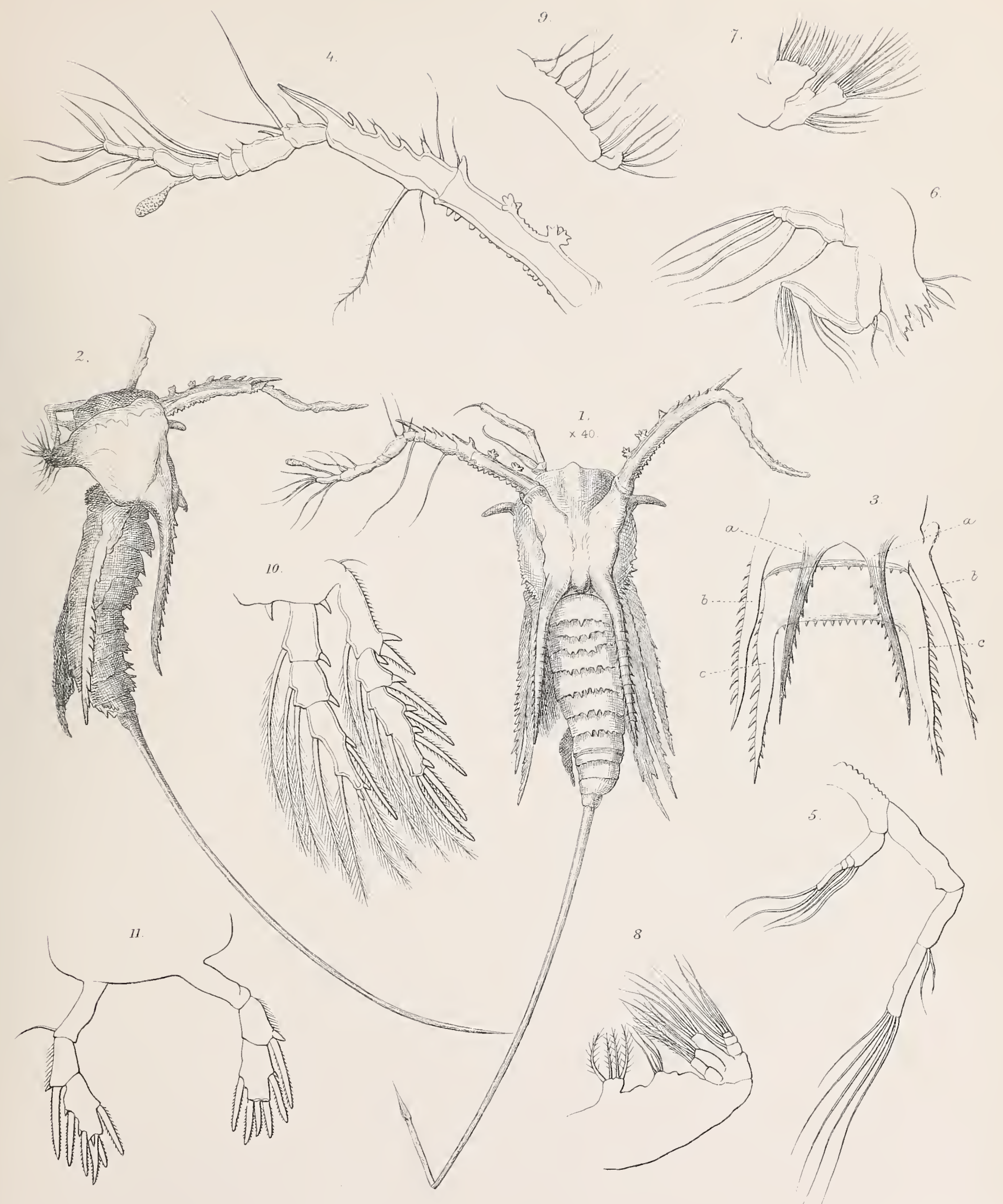



PLA'TE XLV.

(7nOL. CHaLL. EXP.-PART XXIII, - 1883.) -Z 


\section{PLATE XLV}

Figs. 1-9. Pontella securifer, n. sp.

Fig. 1. Right anterior antenna of male.

Fig. 2. Side view of rostrum with eyes (slightly oblique).

Fig. 3. The same, seen from above.

Fig. 4. Mandible and palp.

Fig. 5. Fifth pair of feet of male.

Fig. 6. Fifth pair of feet of female.

Fig. 7. Abdomen of male.

Fig. 8. Abdomen of female (without tail setæ), seen from left side.

Fig. 9. The same, seen from behind.

Figs. 10-15. Pontella inermis, n. sp.

Fig. 10. Male (?), seen from above; magnified 16 diameters.

Fig. 11. Right anterior antenna of the same.

Fig. 12. Left anterior antenna of the same.

Fig. 13. Apex of mandible.

Fig. 14. Terminal and lateral spin es of swimming foot.

Fig. 15. Fifth pair of feet of male?

Figs. 16-19. Pontella strenua, Dana.

Fig. 16. Anterior antenna of male (imperfect).

Fig. 17. Fifth pair of feet of male and extremity of that of left side, more highly magnified.

Figs. 18, 19. Abdomen of two different specimens.

Fig. 20. Pontella detruncata, Dana.

Fig. 20. Fifth pair of feet of female. 


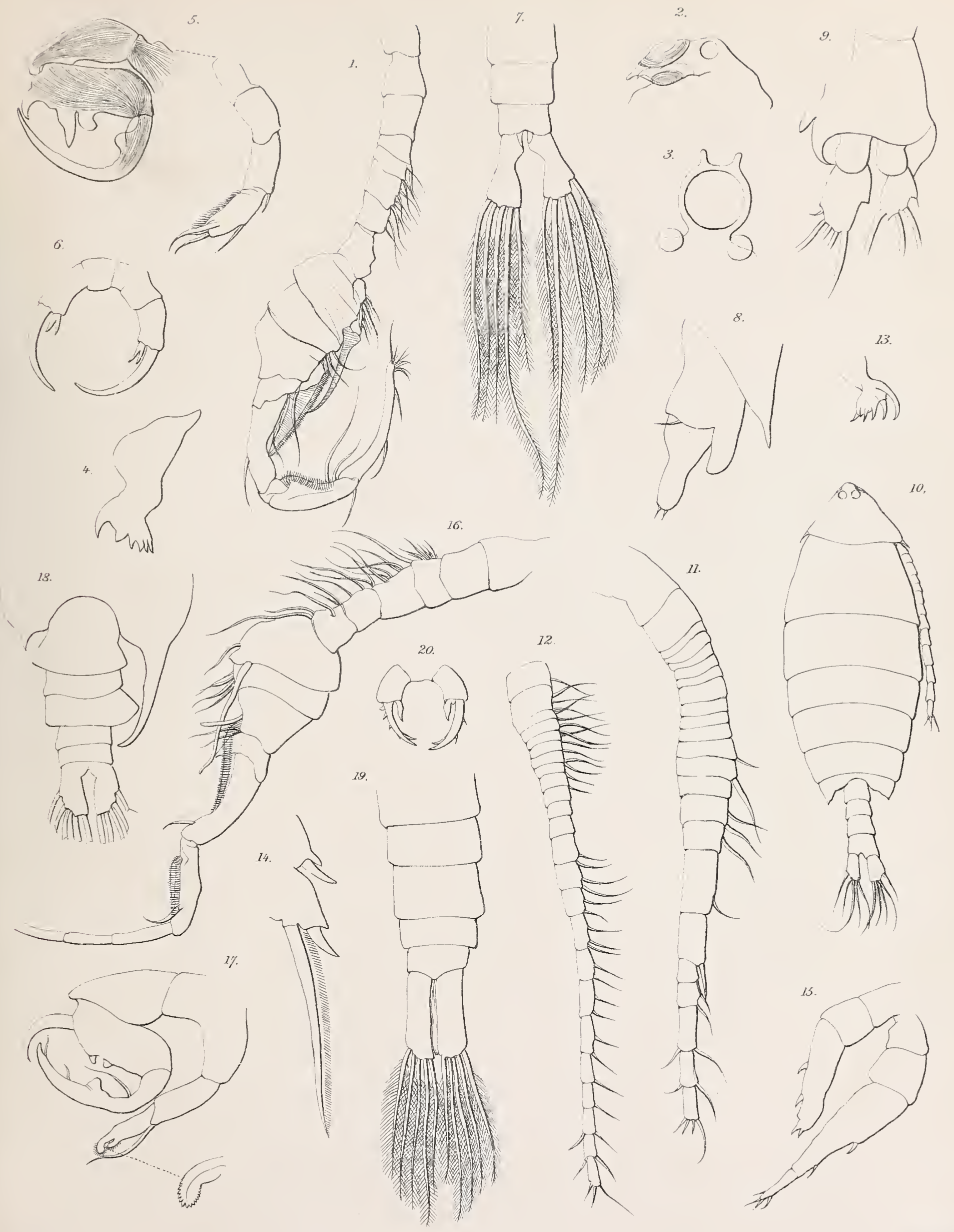

G.S Brady de?

F. Huth, Lithr. $E d \mathrm{~m}^{2}$

1-9 PONTELLA SECURIFER, n.sp. 10-15 P. INERMIS, n.sp

16-19 P. STRENUA, Dana. 20 P. DETRUNCATA, Dana 

PLATE XLVI. 


\section{PLATE XLVI.}

Fig. 1. Calanus gracilis, Dana.

Fig. 1. Outer branch of the first swimming foot.

Figs. 2-4. Hemicalanus aculeatus, n. sp.

Fig. 2. Female (?), seen from above; magnified 16 diameters.

Fig. 3. Maxilla.

Fig. 4. Foot of second pair.

Figs. 5-6. Corycceus speciosus, Dana.

Fig. 5. Adult, seen from above.

Fig. 6. Adult, seen from right side; both magnified 40 diameters.

Figs. 7-9. Corycceus obtusus, Dana.

Fig. 7. Adult, seen from left side; magnified 80 diameters.

Fig. 8. Anterior antenna.

Fig. 9. Posterior antenna. 


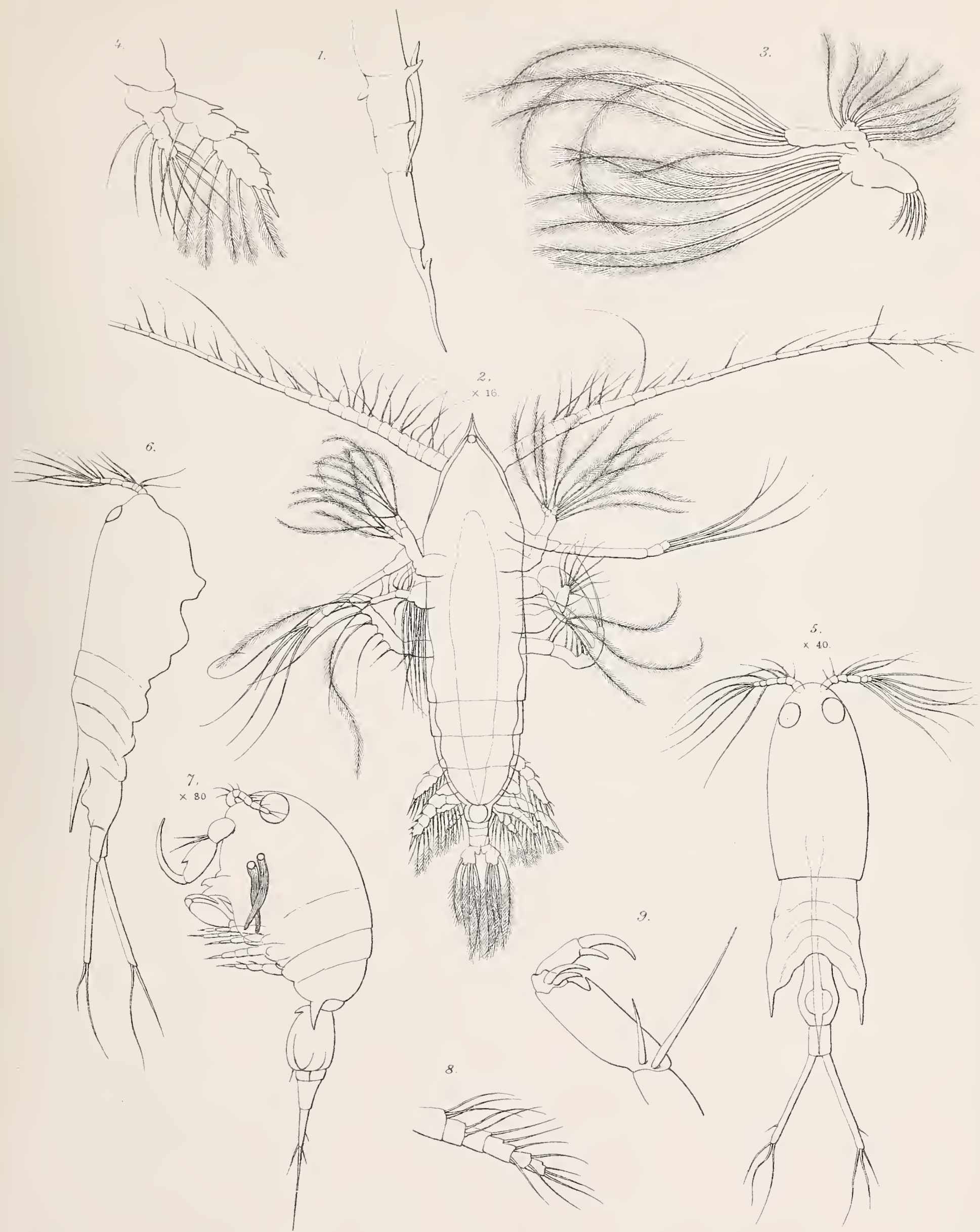


PLATE XLVII.

(ZOOL. CHALL. EXP.—PART XXIII.--1883.) -Z. 


\section{PLATE XLVII.}

\section{Figs. 1-12. Saphirina ovalis, Dana.}

Fig. 1. Male, seen from above; magnified 40 diameters.

Fig. 2. Female, seen from above; magnified 40 diameters.

Fig. 3. Anterior antenna of male.

Fig. 4. Anterior antenna of female.

Fig. 5. Posterior antenna of male.

Fig. 6. Posterior antenna of femali.

Fig. 7. $a$, Mandible ; $b$, maxilla.

Fig. 8. Anterior foot-jaw.

Fig. 9. Posterior foot-jaw.

Fig. 10. Foot of fourth päir.

Fig. 11. Foot of fifth pair.

Fig. 12. Last thoracic segment and abdomen of female.

Figs. 13-16. Saphirinella stylifera (Lubbock).

Fig. 13. Anterior foot-jaw, seen from side.

Fig. 14. Caudal stylets.

Fig. 15. Male genital organs, - $t$, testis; r.s. receptaculum seminis.

Fig. 16. Nervous centres,- $a$, brain; $b b$, antennal nerves; $c c$, pedal nerves. 


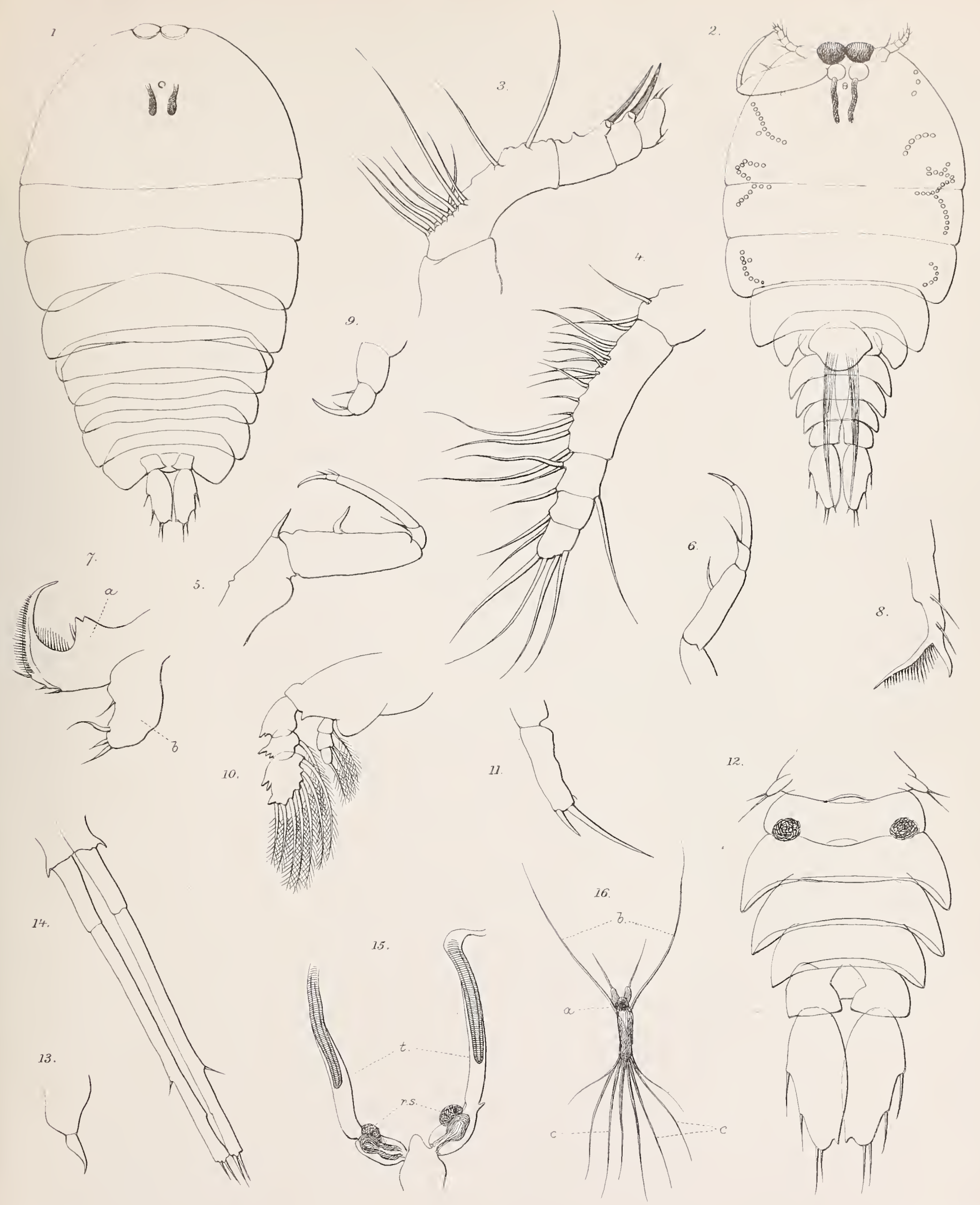

G.S. Brady del. 

PLATE XLVIII. 


\section{PLATE XLVIII.}

Figs. 1-5. Saphirina incequalis, Dana.

Fig. 1. Male, seen from above.

Fig. 2. Female, seen from above; both magnified 40 diameters.

Fig. 3. Anterior antenna.

Fig. 4. Posterior antenna.

Fig. 5. One of the swimming feet.

Figs. 6-8. Saphirina gemma, Dana.

Fig. 6. Female, seen from above; magnified 40 diameters.

Fig. 7. Anterior antenna of female.

Fig. 8. Posterior antenna of the same.

Figs. 9-13. Saphirinella stylifera (Lubbock).

Fig. 9. Male, seen from below; magnified 16 diameters.

Fig. 10. Anterior antenna.

Fig. 11. Posterior antenna.

Fig. 12. Upper lip.

Fig. 13. Posterior foot-jaw. 


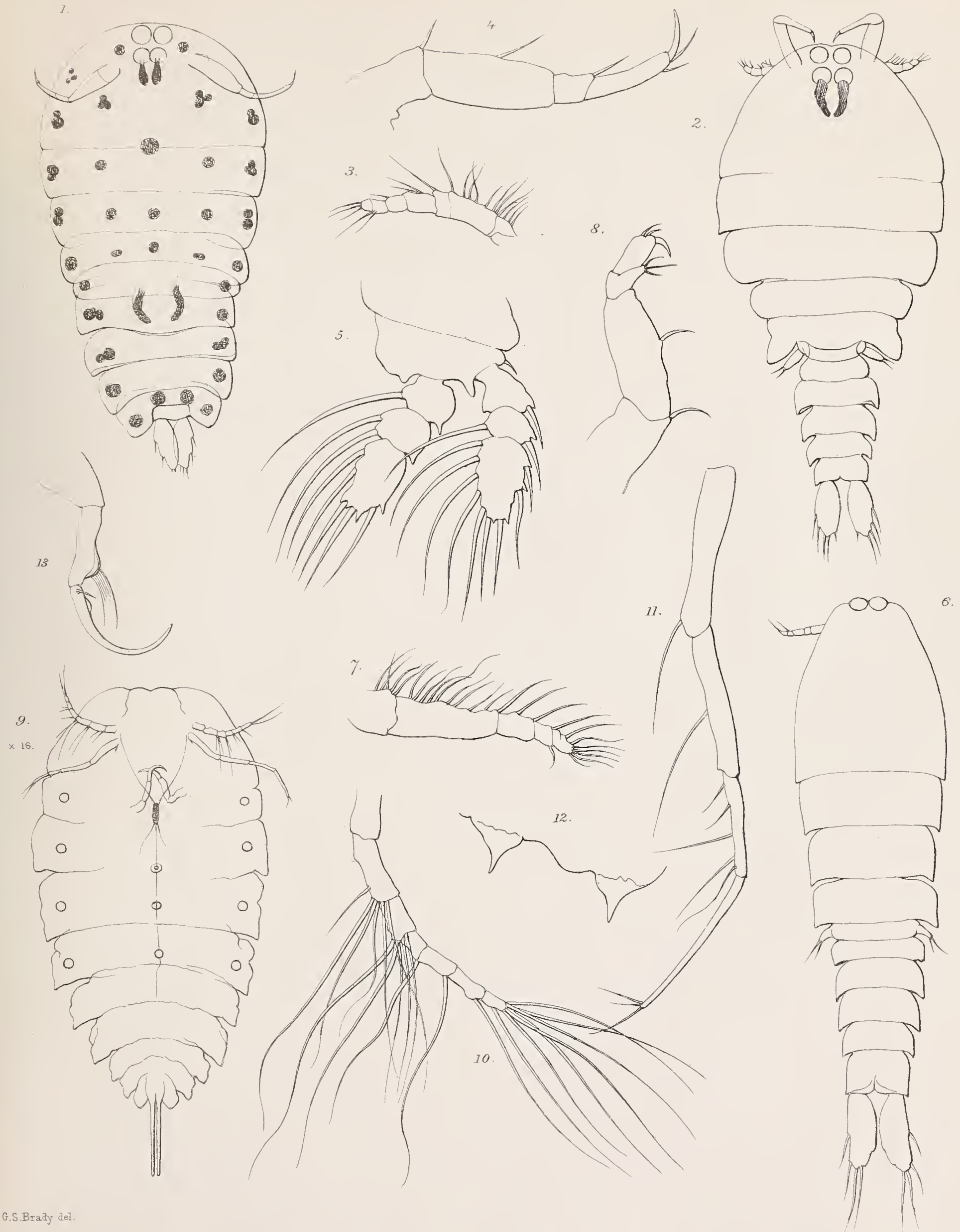

I-5 SAPHIRINA IN EEQUAIS, Dana. 6-8 SAPHIRINA GEM M D, Dana.

9-13 SAPHIRINELLA STYLIFERA, Lubbock. 

PLATE XLIX.

(ZOOL. CHALL, EXP.-PART XXIIL. -1883.)-Z. 


\section{PLATE XLIX.}

Figs. 1, 2. Saphirina serrata, n. sp.

Fig. 1. Female, seen from above; magnified 40 diameters.

Fig. 2. Hinder segments and caudal lamellæ of male, more highly magnified.

Figs. 3-6. Saphirina opalina, Dana.

Fig. 3. Female (? young), seen from above.

Fig. 4. Posterior portion of an adult, both magnified 40 diameters.

Fig. 4. a, Posterior portion of the abdomen of male (?).

Fig. 5. Anterior antenna.

Fig. 5. a, Anterior antenna of male (?).

Fig. 6. Posterior antenna.

Figs. 7-10. Saphirina sinuicauda, n. sp.

Fig. 7. Posterior antenna.

Fig. 8. Last joint, inner branch of second (?) swimming foot.

Fig. 9. Abdomen and caudal stylets of female.

Fig. 10. Posterior abdominal segments and caudal stylets of male.

Figs. 11-13. Saphivina splendens, Dana.

Fig. 11. Abdomen of immature (?) female.

Fig. 12. Caudal lamella of the same.

Fig. 13. Caudal lamella of male (setæ wanting).

Figs. 14-17. Saphirina opaca, Lubbock.

Fig. 14. Anterior antenna.

Fig. 15. Posterior antenna.

Fig. 16. Outer branch of one of the swimming feet.

Fig. 17. Abdomen and last cephalothoracic segment of female.

Figs. 18-22. Corycaus limbatus, n. sp.

Fig. 18. Female, seen from left side; magnified 50 diameters.

Fig. 19. Posterior antenna.

Fig. 20. Posterior foot-jaw.

Fig. 21. Last joint of one of the swimming feet, with magnified spines.

Fig. 22. Posterior thoracic spines, with abdomen and tail. 

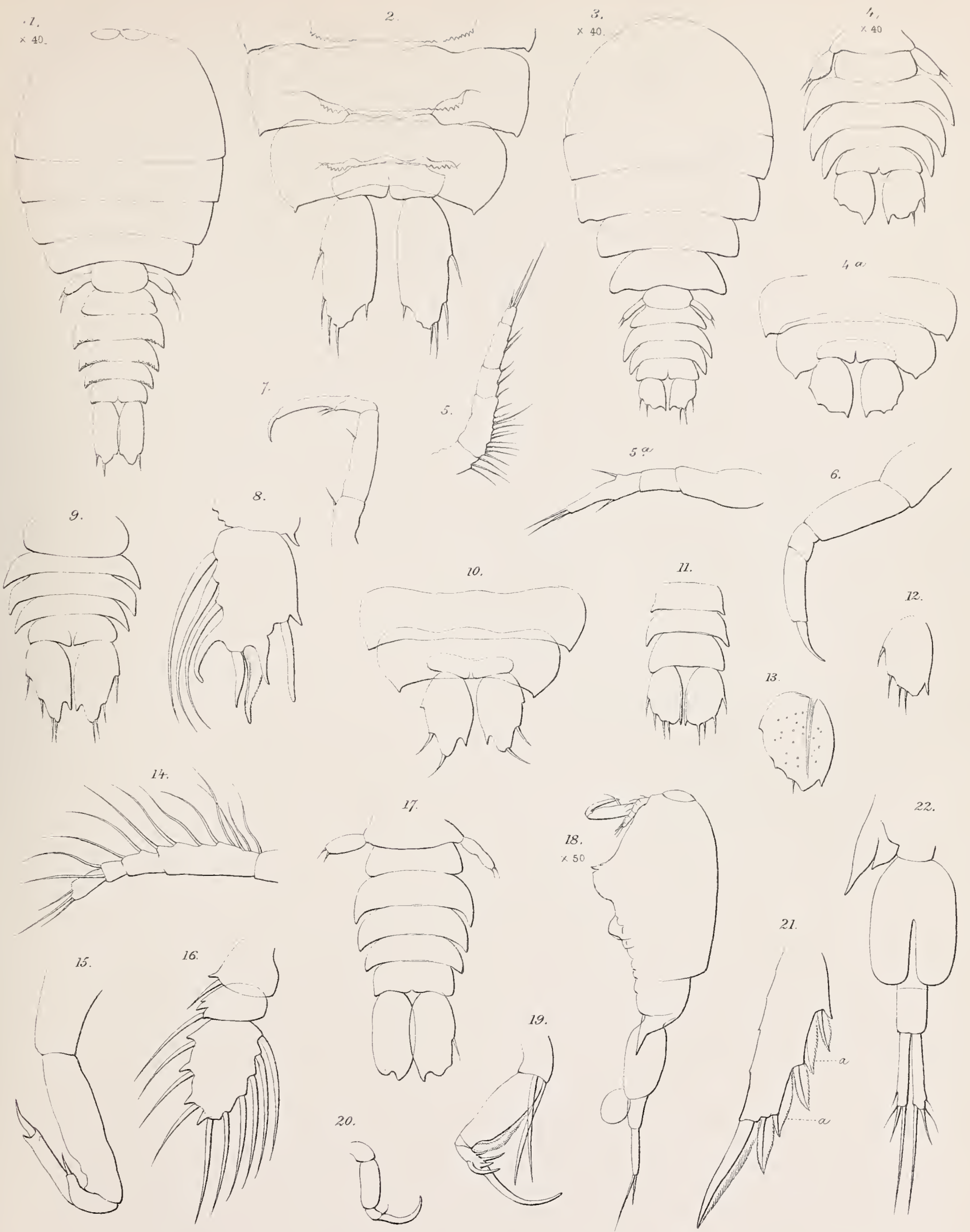

G. S. Brady de].

F. Huth, Inth Inding $^{2}$

1,2 SAPHIRINA SERRATA, n.sp. 3-6 S. OPALINA, Dana. 7-10 S. SINUICAUDA, n. sp 11-13 S. SPLENDENS, Dana. 14-17 S. OPACA, Lubbock. 18-22 CORYCEUS LIMBATUS, n.sp. 

PLATE L. 


\section{PLATE L.}

\section{Figs. 1-10. Setella gracilis, Dana.}

Fig. 1. Female, seen from left side; magnified 80 diameters.

Fig. 2. Anterior antenna of male.

Fig. 3. Posterior antenna.

Fig. 4. Mandible.

Fig. 5. Maxilla.

Fig. 6. Anterior foot-jaw.

Fig. 7. Posterior foot-jaw.

Fig. 8. One of the swimming feet.

Fig. 9. Foot of fifth pair, male.

Fig. 10. The same, female.

Figs. 11-17. Saphirina metallina, Dana.

Fig. 11. Male, seen from above.

Fig. 12. Female, seen from above; both magnified 40 diameters.

Fig. 13. Anterior antenna.

Fig. 14. Posterior antenna.

Fig. 15. Foot of fourth pair.

Fig. 16. Abdomen of female, more highly magnified.

Fig. 17. Corneal lenses.

Fig. 18. Saphirina gemma, Dana.

Fig. 18. Inner branch and portion of outer branch of one of the swimming feet; $a$, one of the apical spines, more highly magnified. 


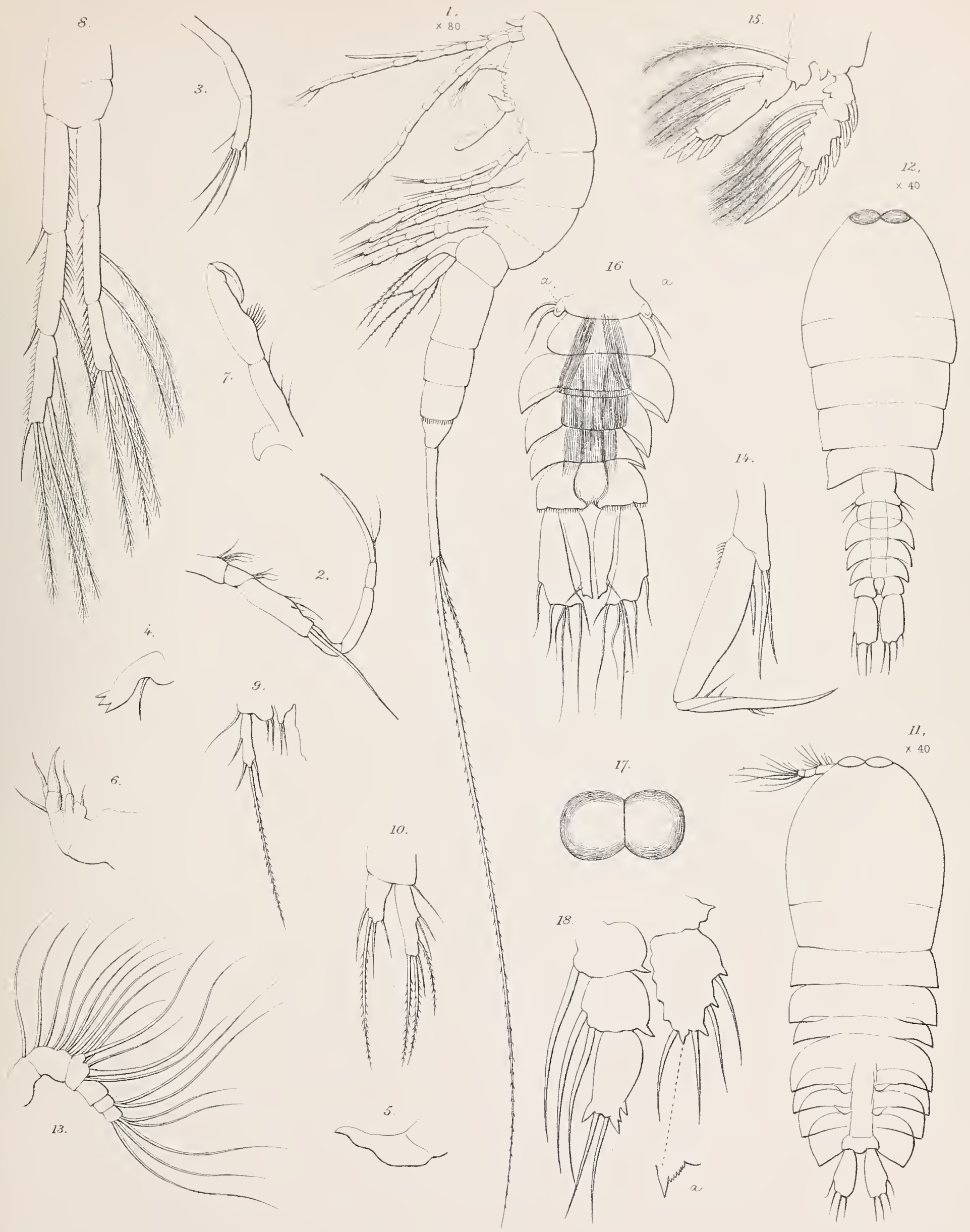

G.S.Braày del. 
PLATE LI.

(ZOOL. CHALL. EXP. -PART XXIH. -1883.)-Z. 


\section{PLATE LI.}

Figs. 1-11. Oncaea obtusa (Dana).

Fig. 1. Female, seen from right side; magnified 80 diameter's.

Fig. 2. Abdomen of female, seen from the front.

Fig. 3. Abdomen of male, seen from the front.

Fig. 4. Anterior antenna.

Fig. 5. Posterior antenna.

Fig. 6. $a$, Mandible; $b$, maxilla.

Fig. 7. Anterior foot-jaw.

Fig. 8. Posterior foot-jaw of female.

Fig. 9. Posterior foot-jaw of male.

Fig. 10. Foot of first pair.

Fig. 11. Foot of fourth pair.

Figs. 12-14. Saphirina reticulata, n. sp.

Fig. 12. Male, seen from above; magnified 40 diameters.

Fig. 13. Posterior antenna.

Fig. 14. A caudal lamella, more highly magnified. 


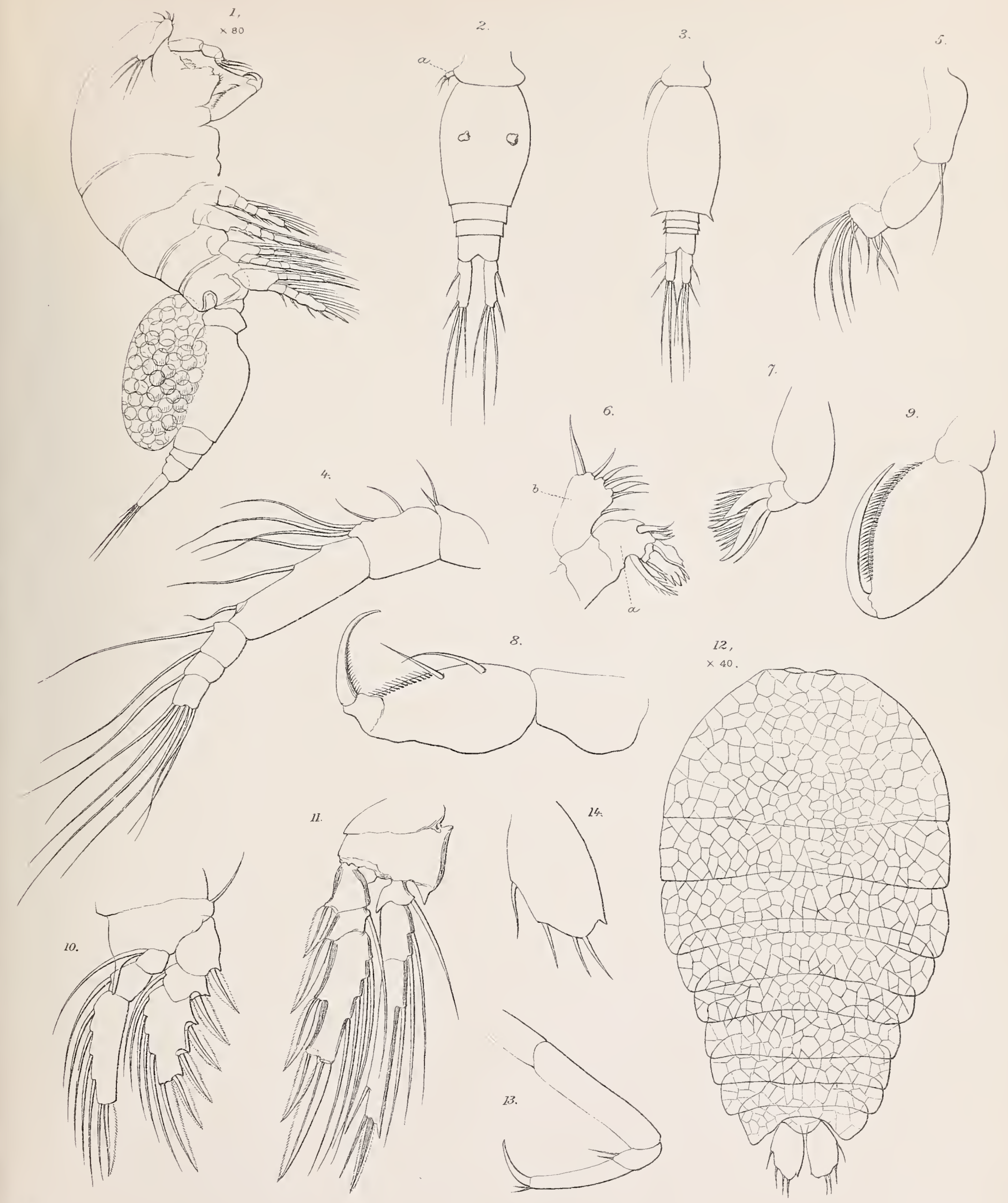

G.S.Brady lel.

1-11 ONCEA OBTUSA, Dana. I2-14 SAPHIRINA RETICULATA, n. sp. 

PLATE LII. 


\section{PLATE LII.}

Figs. 1-1.4. Corycaus varius, Dana.

Fig. 1. Female, seen from above; $a$, lateral processes of third thoracic segment.

Fig. 2. The same, seen from left side; both magnified 40 diameters.

Fig. 3. Abdomen of female, seen laterally.

Fig. 4. Abdomen of male, seen from the front.

Fig. 5. Abdomen of immature female, seen from the front.

Fig. 6. Anterior antenna.

Fig. 7. Posterior antenna of male.

Fig. 8. Posterior antenna of female.

Fig. 9. $a$, Mandible; $a^{\prime}, a^{\prime}$, apical processes; $a^{\prime \prime}$, palp; $b$, maxilla.

Fig. 10. Anterior foot-jaw.

Fig. 11. Posterior foot-jaw.

Fig. 12. Foot of first pair.

Fig. 13. Foot of third pair.

Fig. 14. Foot of fourth pair.

Figs. 15-19. Corycceus pellucidus, Dana.

Fig. 15. Female, seen from left side; magnified 80 diameters.

Fig. 16. Anterior antenna.

Fig. 17. Posterior antenna.

Fig. 18. Posterior foot-jaw.

Fig. 19. Abdomen and tail with attached spermatophores. 


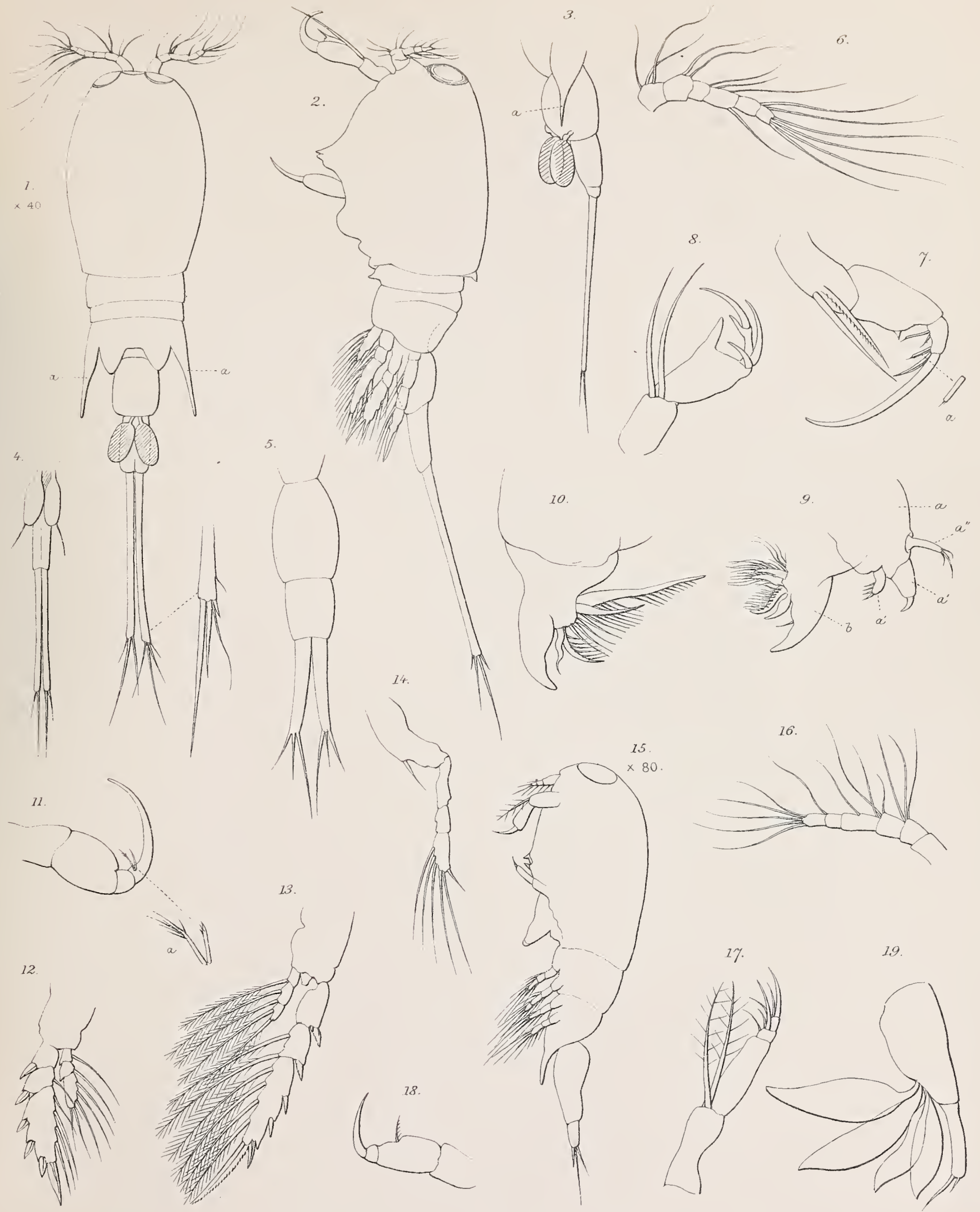



PLATE LIII.

(ZOOL. CHALL. EXP,-PART XXIII.-1883.)-Z. 


\section{PLATE LIII.}

Figs. 1-11. Copilia mirabilis, Dana.

Fig. 1. Female (?), seen from above.

Fig. 2. The same, seen from right side; both magnified 40 diameters.

Fig. 3. Anterior antenna.

Figs. 4, 5. Posterior antenna of male and female (?)

Fig. 6. Mandible.

Fig. 7. Maxilla (?).

Fig. 8. Anterior foot-jaw.

Fig. 9. Posterior foot-jaw.

Fig. 10. Foot of first pair.

Fig. 11. Foot of fourth pair.

Figs. 12-16. Lubbockia squillimana, Claus.

Fig. 12. Anterior antenna of female.

Fig. 13. Posterior antenna.

Fig. 14. Posterior foot-jaw of female.

Fig. 15. One of the swimming fect.

Fig. 16. Foot of fifth pair. 

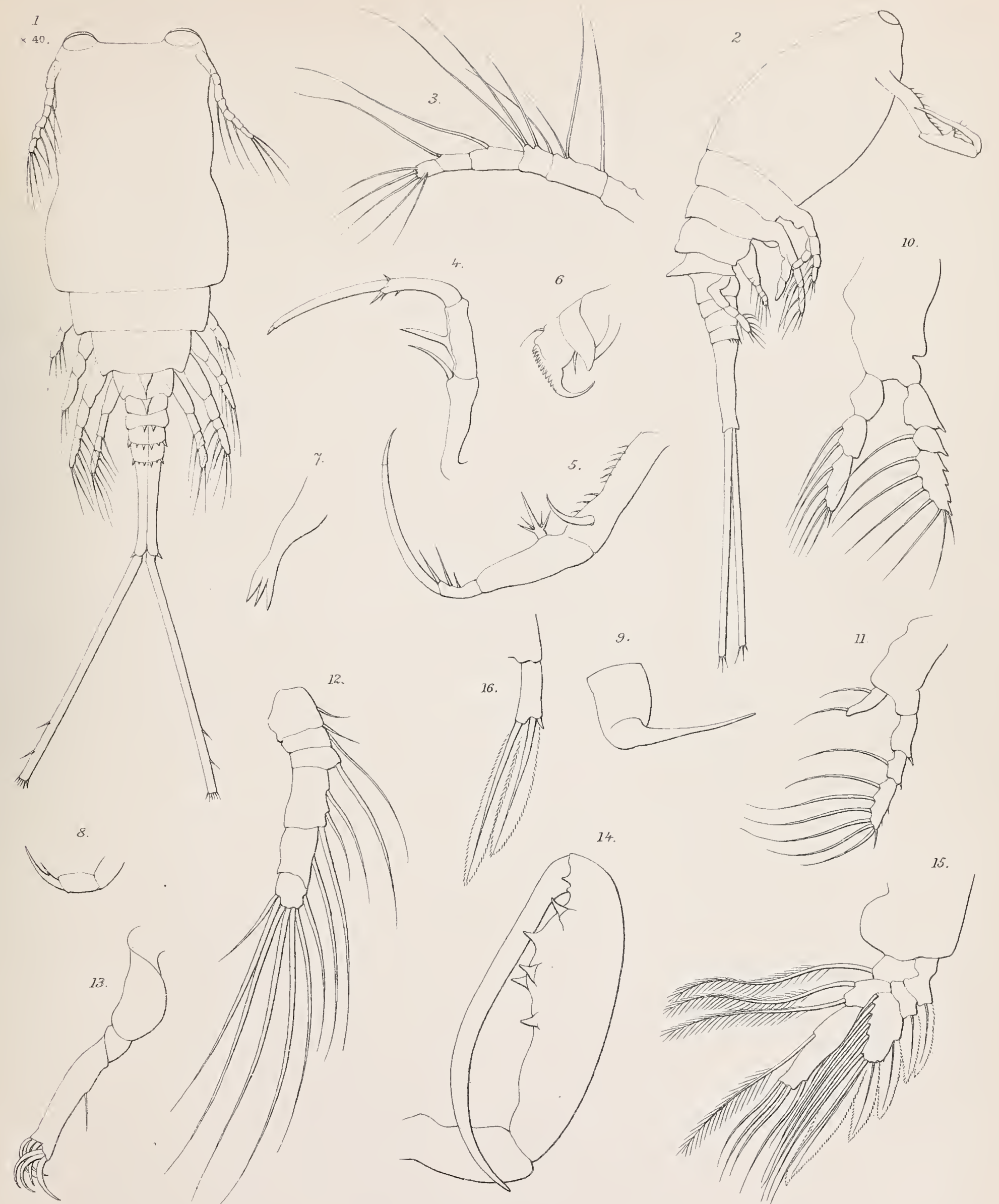

Plate LIV. 


\section{PLATE LIV}

Figs. 1-7. Lubbockia squillimana, Claus.

Fig. 1. Female, seen from above.

Fig. 2. The same, seen from left side.

Fig. 3. Male, seen from above.

Fig. 4. The same, seen from left side; all magnified 80 diameters.

Fig. 5. Mandible.

Fig. 6. Anterior foot-jaw.

Fig. 7. Posterior foot-jaw of male.

Figs. 8 10. Corycaus venustus, Dana.

Fig. 8. Female, seen from above; magnified 40 diameters.

Fig. 9. Posterior antenna.

Fig. 10. Last abdominal segment and tail. 
The Voyage of H. M.S "Challenger".

Copepuda Pl. Lily.

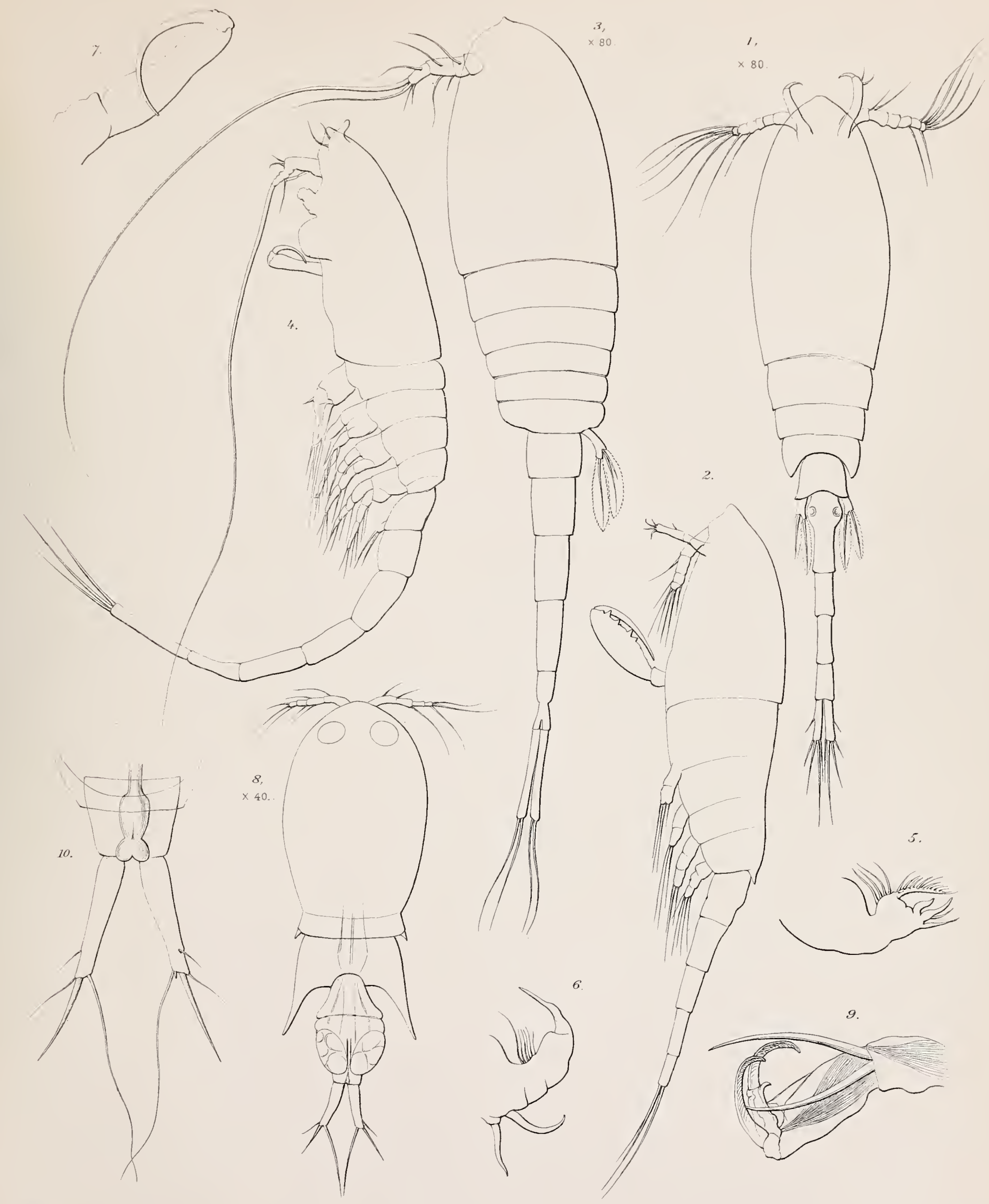

G.S. Brady del 



\section{PLATE LV.}

(ZOOL. CHALL. EXP. —PART XXII. - 1883.) -Z 


\section{PLATE LV.}

Fig. 1. Nogagus murrayi, n. sp.

Fig. 1. Adult female (?), seen from below; magnified 20 diameters.

Fig, 2. Lepeophtheirus suhmi, n. sp.

Fig. 2. Female, seen from below; magnified 24 diameters.

Fig. 3. Pandarus zygono, n. sp.

Fig. 3. Adult male, seen from above; magnified 16 diameters.

Figs. 4-8. Chondracanthus macrurus, n. sp.

Fig. 4. Adult, magnified 16 diameters.

Fig. 5. Posterior antenna.

Figs. 6, 7. Mouth-organs.

Fig. 8. Foot-jaw?

Figs. 9-13. Hessella cylindrica, n. gen. and sp.

Fig. 9. Adult, magnified 40 diameters.

Fig. 10. Anterior antenna.

Fig. 11. Posterior antenna (?).

Fig. 12. Foot of first pair.

Fig. 13. Foot of third pair. 

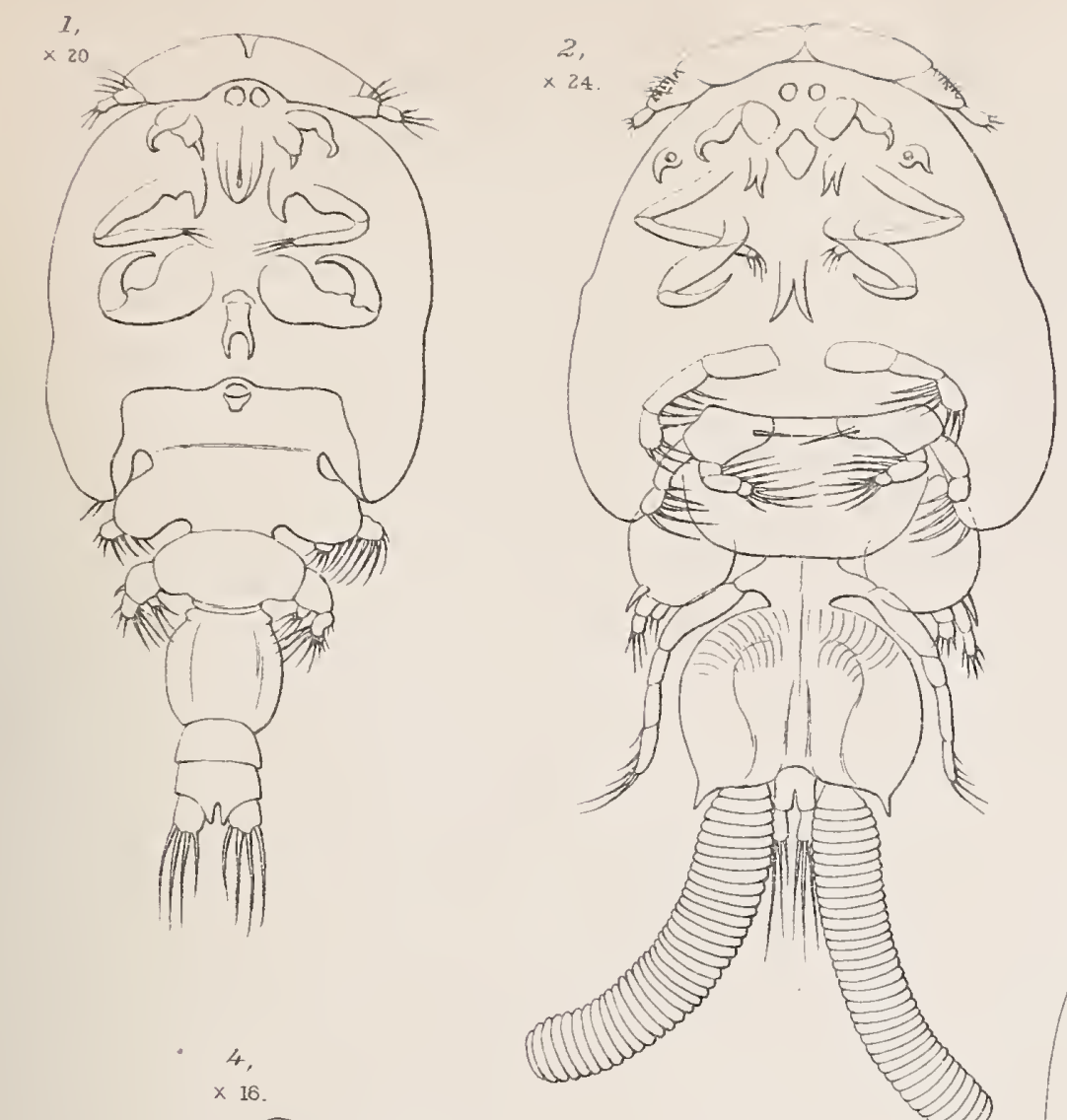

WILSON COPEPOD LIBRARY

Smithsonian Institution

Invertebrate Zoology

(Crustacea) 

WILSON COPEPOD LIBRARY Smithso:iian Institution invertehrate Zoology (Crustacea) 

WILSON COPEPOD LIBRARY

Srnithsonian Institution

Invartcorate Zociogy

(Crustacea) 
